PEDOMORFOGEOLOGIA E MAPEAMENTO DIGITAL DE SOLOS COM HORIZONTE B TEXTURAL E B NÍTICO EM UMA ÁREA PILOTO NO PLANALTO CENTRAL DO BRASIL.

ROSANA QUIRINO DE SOUZA

DISSERTAÇÃO DE MESTRADO EM AGRONOMIA

BRASÍLIA/DF

FEVEREIRO/2015 


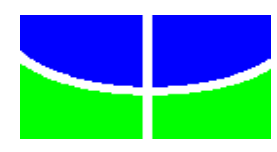

UNIVERSIDADE DE BRASÍLIA

FACULDADE DE AGRONOMIA E MEDICINA VETERINÁRIA PROGRAMA DE PÓS-GRADUAÇÃO EM AGRONOMIA

\section{PEDOMORFOGEOLOGIA E MAPEAMENTO DIGITAL DE SOLOS COM HORIZONTE B TEXTURAL E B NÍTICO EM UMA ÁREA PILOTO NO PLANALTO CENTRAL DO BRASIL.}

ROSANA QUIRINO DE SOUZA

DISSERTAÇÃO DE MESTRADO EM AGRONOMIA

PUBLICAÇÃO: 89/2015

BRASÍLIA/DF, FEVEREIRO de 2015. 


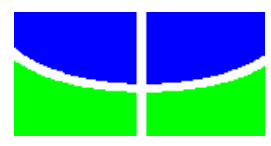

UNIVERSIDADE DE BRASÍLIA

FACULDADE DE AGRONOMIA E MEDICINA VETERINÁRIA

PROGRAMA DE PÓS-GRADUAÇÃO EM AGRONOMIA

\section{PEDOMORFOGEOLOGIA E MAPEAMENTO DIGITAL DE SOLOS COM HORIZONTE B TEXTURAL E B NÍTICO EM UMA ÁREA PILOTO NO PLANALTO CENTRAL DO BRASIL}

ROSANA QUIRINO DE SOUZA

DISSERTAÇÃO DE MESTRAdo SUBMETIDA AO PROGRAMA DE PÓSGRADUAÇÃO EM AGRONOMIA, COMO PARTE DOS REQUISITOS NECESSÁRIOS À OBTENÇÃO DO GRAU DE MESTRE EM AGRONOMIA.

APROVADA POR:

MARILUSA PINTO COELHO LACERDA, Doutora, Professora Associada. (Faculdade de Agronomia e Medicina Veterinária - Universidade de Brasília) (ORIENTADORA) E-mail: marilusa@unb.br CPF: 434.760.586-20

INARA OLIVEIRA BARBOSA, Doutora, Pesquisadora. (Departamento Nacional de Produção Mineral - DNPM) (EXAMINADOR EXTERNO) E-mail: inarabar@yahoo.com.br CPF: 538.956.731-53

EIYTI KATO, Doutor. Professor Adjunto. (Faculdade de Agronomia e Medicina Veterinária - Universidade de Brasília) (EXAMINADOR INTERNO) E-mail: kato@unb.br CPF: 143.483.571-53

BRASÍLIA/DF, 27 de FEVEREIRO de 2015. 


\section{FICHA CATALOGRÁFICA}

Souza, Rosana Quirino de

Pedomorfogeologia e mapeamento digital de solos com horizonte B textural e B nítico em uma área piloto no Planalto Central do Brasil/ Rosana Quirino de Souza; orientação de Marilusa Pinto Coelho Lacerda. - Brasília, 2015.

143p. : il.

Dissertação de Mestrado (M) - Universidade de Brasília/Faculdade de Agronomia e Medicina Veterinária, 2015.

1. Gênese dos solos. 2. Modelagem. 3. SIG. 4. Mineralogia. I. Lacerda, M.P.C. II. Doutora.

\section{REFERÊNCIA BIBLIOGRÁFICA}

SOUZA, R. Q. Pedomorfogeologia e mapeamento digital de solos com horizonte B textural e B nítico em uma área piloto no Planalto Central do Brasil. Brasília: Faculdade de Agronomia e Medicina Veterinária, Universidade de Brasília, 2015, 143p. Dissertação de Mestrado.

\section{CESSÃO DE DIREITOS}

NOME DO AUTOR: Rosana Quirino de Souza

TÍTULO DA DISSERTAÇÃO: Pedomorfogeologia e mapeamento digital de solos com horizonte B textural e B nítico em uma área piloto no Planalto Central do Brasil.

GRAU: Mestre

ANO: 2015

É concedida à Universidade de Brasília permissão para reproduzir cópias desta dissertação de mestrado para única e exclusivamente propósitos acadêmicos e científicos. O autor reserva para si os outros direitos autorais, de publicação. Nenhuma parte desta dissertação de mestrado pode ser reproduzida sem a autorização por escrito do autor. Citações são estimuladas, desde que citada à fonte.

Rosana Quirino de Souza

CPF: 033.128.131-74

(61) 8637-0287

E-mail: rosanakirino@gmail.com 
Dedico aos meus pais Israel e Doralice, Ofereço aos meus irmãos Luana, Flávio e Raiana. 
"Se não buscarmos o impossível, acabamos por não realizar o possível"

Leonardo Boff. 


\section{AGRADECIMENTOS}

À minha família pelo amor, carinho, compreensão, exemplo, incentivo e apoio em todos os momentos.

À Professora Marilusa pela oportunidade, orientação e amizade.

À Professora Edi Guimarães, ao mestrando Rafael do Laboratório de Difratometria de Raios-X, pelo auxílio na realização das análises mineralógicas.

Ao Professor Elton, ao técnico Marcelo do Laboratório de Geocronologia, por ter realizado minhas análises geoquímicas.

À Inara pelas valiosas contribuições nessa dissertação.

Ao Manuel pelo auxílio nos trabalhos de campo e nas análises físicas e mineralógicas.

À Bruna pela cessão dos dados.

Às amigas Ana Paula e Taís pelo apoio, carinho, companheirismo e amizade.

Aos Professores do Programa de Pós Graduação em Agronomia, em especial os Professores Eiyti, Cícero Célio e Tairone pela pronta disponibilidade em auxiliar.

À todos que de alguma forma contribuíram para o desenvolvimento deste trabalho. 


\section{LISTA DE ABREVIAÇÕES}

AG - Acurácia Global

AM - Acurácia do Mapeador

AU - Acurácia do Usuário

CODEPLAN - Companhia de Planejamento do Distrito Federal

EMBRAPA - Empresa Brasileira de Pesquisa Agropecuária

IBGE - Instituto Brasileiro de Geografia e Estatística

INPE - Instituto Nacional de Pesquisas Espaciais

MDS - Mapeamento Digital de Solos

MDE - Modelo Digital de Elevação

MDT - Modelo Digital de Terreno

MNT - Modelo Numérico de Terreno

RNA - Redes Neurais Artificiais

RLM - Regressão Logística Múltipla

SEMARH - Secretaria de Meio Ambiente e Recursos Hídricos

SICAD - Sistema Cartográfico do Distrito Federal

SIG - Sistema de Informação Geográfica

SRTM - Shuttle Radar Topography Mission

UTM - Sistema Universal Transverso de Mercator

ZEE - Zoneamento Ecológico Econômico 


\section{SUMÁRIO}

\section{CAPÍTULO GERAL}

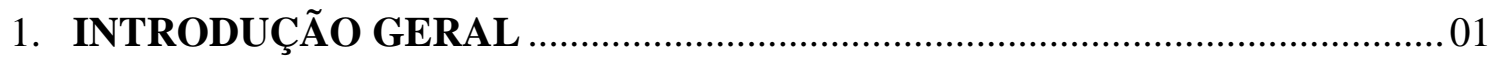

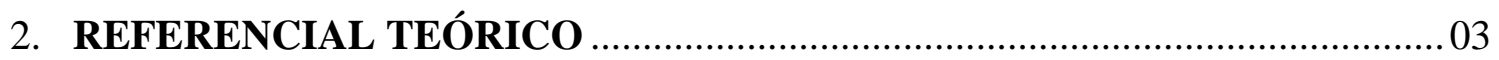

2.1 Contexto Geológico do Distrito Federal .................................................................. 03

2.2 Contexto Geomorfológico do Distrito Federal ....................................................... 06

2.3 Contexto Pedológico do Distrito Federal …………………………………….... 08

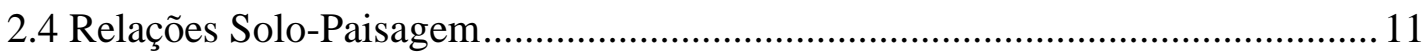

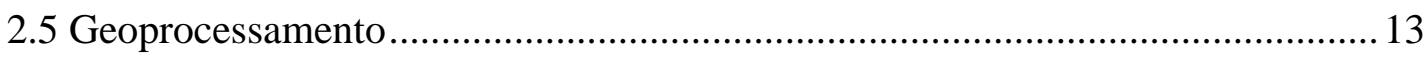

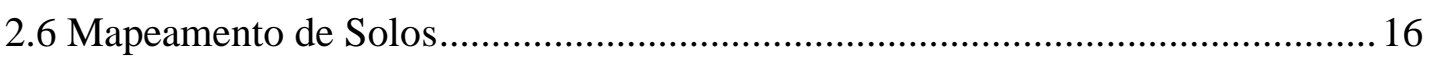

2.6.1 Mapeamento Tradicional de Solos ........................................................... 17

2.6.2 Mapeamento Digital de Solos ...................................................................... 18

2.6.2.1 Redes Neurais Artificiais ..................................................................... 20

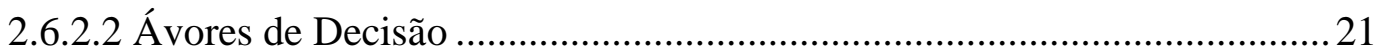

2.6.2.3 Regressão Logística Múltipla (RLM) ………………………………..... 22

2.6.2.4 Regressão Linear Múltipla.................................................................... 23

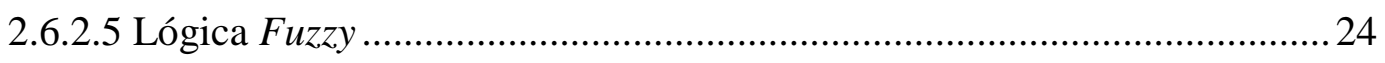

2.6.2.6 Pesos de Evidência................................................................................... 26

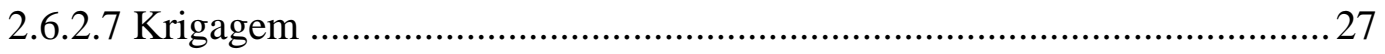

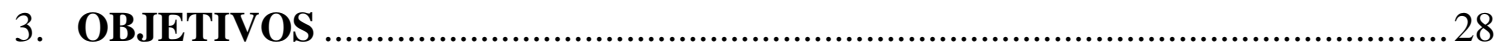

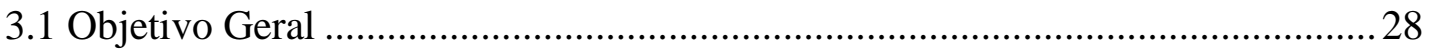

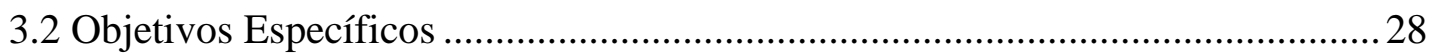

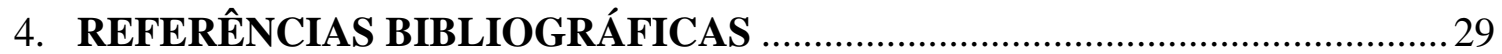

CAPÍTULO 1

5. SOLOS COM HORIZONTE B TEXTURAL E B NÍTICO EM UMA ÁREA PILOTO DO PLANALTO CENTRAL DO BRASIL …………………………..... 42

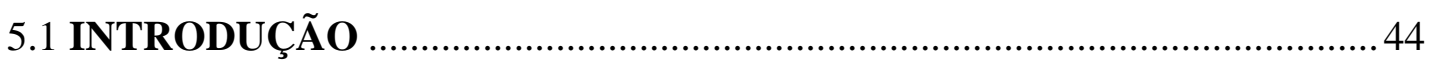

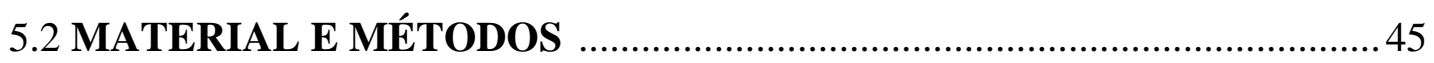

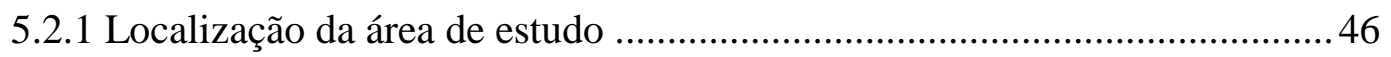

5.2.2 Caracterização do meio físico da microbacia do Ribeirão Salinas, DF ....... 47

5.2.3 Seleção e caracterização dos solos em geo-topossequências..........................51

5.2.4 Análises Morfológicas ............................................................................ 52 


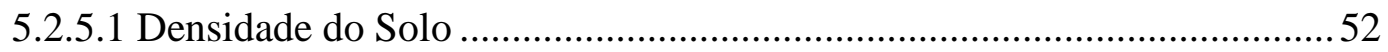

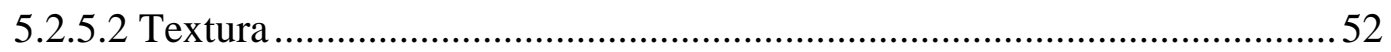

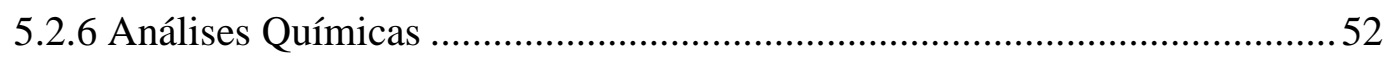

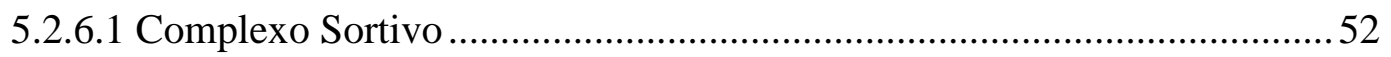

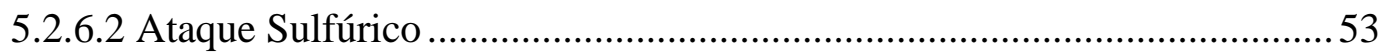

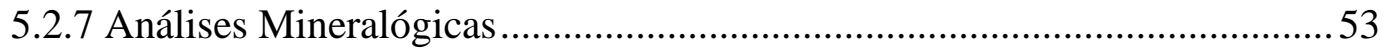

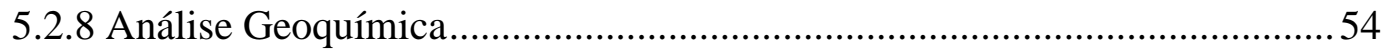

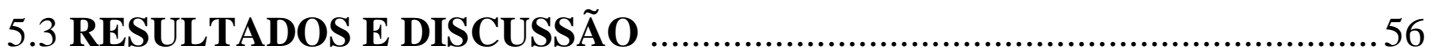

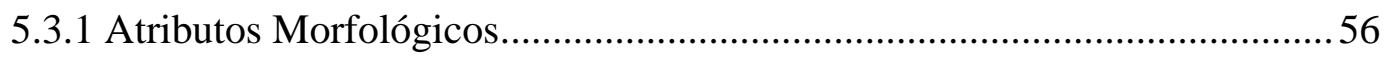

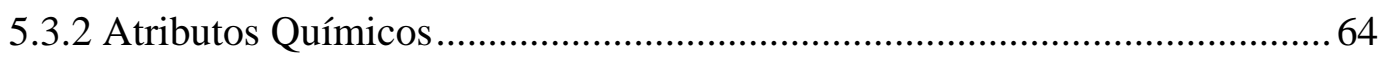

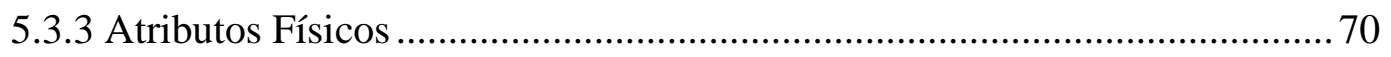

5.3.4 Teores de $\mathrm{SiO}_{2}, \mathrm{Al}_{2} \mathrm{O}_{3}, \mathrm{Fe}_{2} \mathrm{O}_{3}$ e Índices $\mathrm{Ki} \mathrm{e} \mathrm{Kr}$........................................ 74

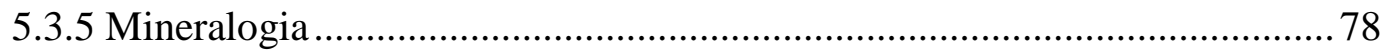

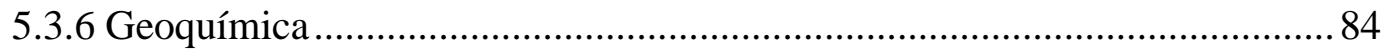

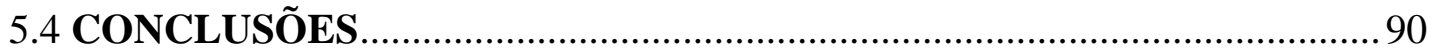

5.5 REFERÊNCIAS BIBLIOGRÁFICAS ..................................................... 91 CAPÍTULO 2

6. MAPEAMENTO DIGITAL DOS SOLOS COM HORIZONTE B TEXTURAL E B NíTico EM UMA ÁrEA PILOTO DO PLANALTO

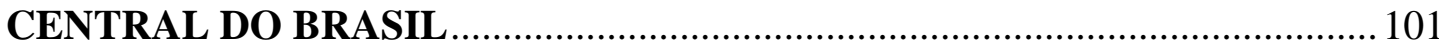

6.1 INDRODUÇÃ

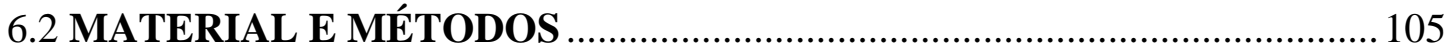

6.2.1 Caracterização da área de estudo .............................................................. 105

6.2.1.1 Caracterização do meio físico da microbacia do Ribeirão Salinas, DF.... 106

6.2.2 Modelo de distribuição dos solos da microbacia do Ribeirão Salinas, DF.. 109

6.2.2.1 Estabelecimento das relações pedomorfogeológicas da microbacia do Ribeirão Salinas.

6.2.3 Aplicação da lógica fuzzy no mapeamento digital com enfoque aos solos com horizonte B textural e B nítico

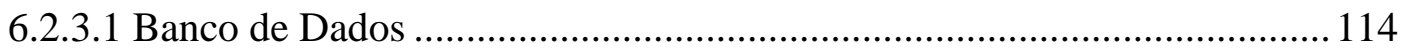

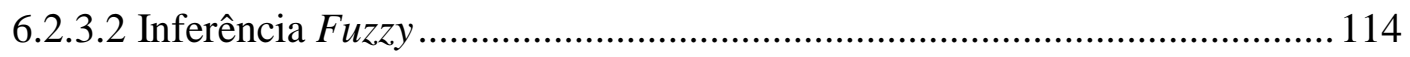

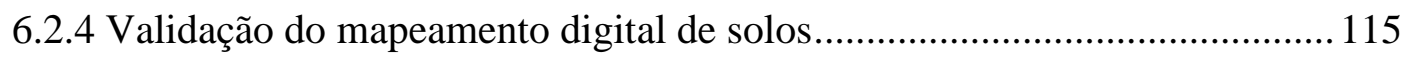

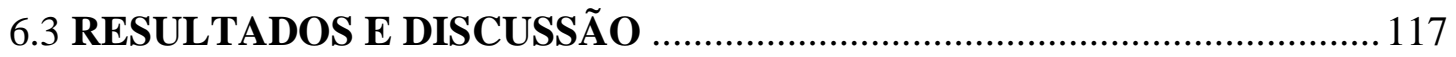




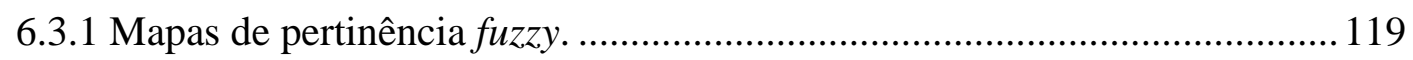

6.3.2 Mapa digital de solos e avaliação da exatidão do mapeamento ................... 120

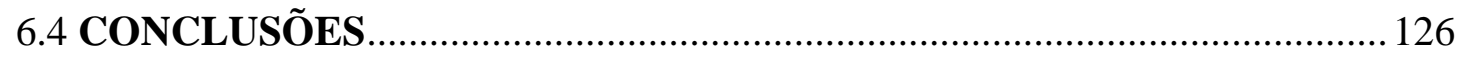

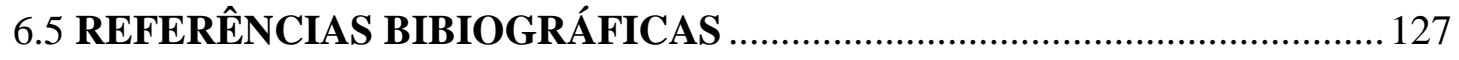




\section{ÍNDICE DE TABELAS}

\section{CAPÍTULO 1}

Tabela 1. Características morfológicas dos perfis da Geo-topossequência Catingueiro .......58

Tabela 2. Características morfológicas dos perfis da Geo-topossequência Pedreira............. 60

Tabela 3. Características morfológicas dos perfis da Geo-topossequência DF-205 ............ 62

Tabela 4. Análises Químicas dos solos da Geo-topossequência Catingueiro ....................... 66

Tabela 5. Análises Químicas dos solos da Geo-topossequência Pedreira ............................. 67

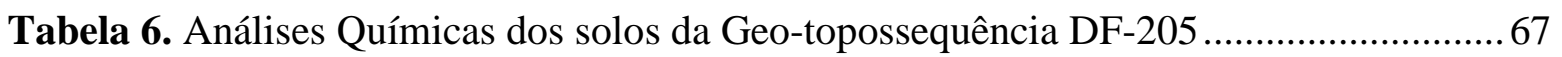

Tabela 7. Análises Físicas dos solos dos perfis da Geo-topossequência Catingueiro ........... 71

Tabela 8. Análises Físicas dos solos dos perfis da Geo-topossequência Pedreira................ 71

Tabela 9. Análises Físicas dos solos dos perfis da Geo-topossequência DF-205 ................ 71

Tabela 10. Teores de $\mathrm{SiO}_{2}, \mathrm{Al}_{2} \mathrm{O}_{3}, \mathrm{Fe}_{2} \mathrm{O}_{3}$, índices $\mathrm{Ki}$ e $\mathrm{Kr}$ da Geo-topossequência

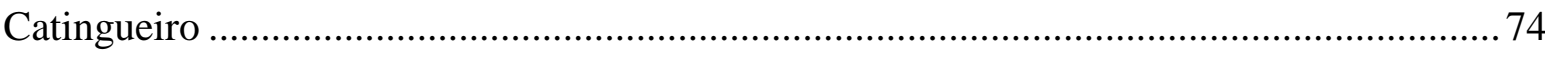

Tabela 11. Teores de $\mathrm{SiO}_{2}, \mathrm{Al}_{2} \mathrm{O}_{3}, \mathrm{Fe}_{2} \mathrm{O}_{3}$, índices $\mathrm{Ki}$ e $\mathrm{Kr}$ da Geo-topossequência Pedreira .75

Tabela 12. Teores de $\mathrm{SiO}_{2}, \mathrm{Al}_{2} \mathrm{O}_{3}, \mathrm{Fe}_{2} \mathrm{O}_{3}$, índices $\mathrm{Ki}$ e $\mathrm{Kr}$ da Geo-topossequência Pedreira da Geo-topossequência DF-205

Tabela 13. Análise geoquímica dos óxidos constituintes da Geo-topossequência Catingueiro 86

Tabela 14. Análise geoquímica dos elementos-traço da Geo-topossequência Catingueiro . 86

Tabela 15. Análise geoquímica dos óxidos constituintes da Geo-topossequência Pedreira. 87

Tabela 16. Análise geoquímica dos elementos-traço da Geo-topossequência Pedreira 87

Tabela 17. Análise geoquímica dos óxidos constituintes da Geo-topossequência DF-205 .88

Tabela 18. Análise geoquímica dos elementos-traço da Geo-topossequência DF-205 ........ 88 CAPÍTULO 2

Tabela 19. Modelo de distribuição de solos na paisagem da microbacia do Ribeirão Salinas, DF

Tabela 20. Classificação dos valores do coeficiente Kappa, segundo Landis e Koch (1977)

Tabela 21. Peso dos atributos avaliados para as classes Argissolo Vermelho-Amarelo, Chernossolo Argilúvico, Nitossolo Vermelho, Nitossolo Háplico, Chernossolo Háplico .... 118 Tabela 22. Matriz de erros entre a verdade de campo e o mapa digital de solos com horizonte B textural e B nítico da microbacia do Ribeirão Salinas, DF. 


\section{ÍNDICE DE FIGURAS}

\section{CAPÍTULO GERAL}

Figura 1. Mapa Geológico do Distrito Federal (Fonte: Freitas-Silva e Campos, 1998) ....... 03

Figura 2. Mapa da Compartimentação Geomorfológica do Distrito Federal (Codeplan, 1984)

Figura 3. Mapa Pedológico do Distrito Federal (modificado de Embrapa, 1978) 09 CAPÍTULO 1

Figura 4. Fluxograma resumido da metodologia utilizada no estudo 46

Figura 5. Localização da microbacia do Ribeirão Salinas, DF. Fotografia Aérea (Codeplan, 2009)

Figura 6. Localização das geo-topossequências da microbacia do Ribeirão Salinas, DF ....51

Figura 7. Foto da Geo-topossequência Catingueiro.(a) NITOSSOLO HÁPLICO Distrófico úmbrico, (b) ARGISSOLO VERMELHO Eutroférrico típico, (c) CHERNOSSOLO ARGILÚVICO Férrico típico, (d) ARGISSOLO VEMELHO-AMARELO Distrófico típico...........59 Figura 8. Foto da Geo-topossequência Pedreira. (a) NITOSSOLO HÁPLICO Distrófico típico, (b) NITOSSOLO VERMELHO Eutrófico chernossólico, (c) NITOSSOLO VERMELHO Eutrófico chernossólico.

Figura 9. Foto da Geo-topossequência DF-205. (a) CHERNOSSOLO HÁPLICO Férrico típico (b) ARGISSOLO VERMELHO Eutroférrico típico, (c) NITOSSOLO VERMELHO Distroférrico típico

Figura 10. Difratogramas do horizonte B dos perfis da Geo-topossequência Catingueiro. A) NXd, B) PVef, C) MTf, D) PVAd

Figura 11. Difratogramas do horizonte B dos perfis da Geo-topossequência Pedreira. A)

$\mathrm{NXd}, \mathrm{B}) \mathrm{NVe}, \mathrm{C}) \mathrm{NVe}$. 80

Figura 12. Difratogramas do horizonte B dos perfis da Geo-topossequência DF-205. A) MXf, B) PVef, C) NVf

\section{CAPÍTULO 2}

Figura 13. Localização da microbacia do Ribeirão Salinas, DF. Fotografia Aérea (Codeplan, 2009) 106

Figura 14. Fluxograma resumido da metodologia utilizada neste estudo 110

Figura 15. A) Mapa de classes de declividade, B) Mapa de altimetria, C) Mapa de curvatura e D) Mapa de geologia (Freitas-Silva e Campos, 1998) da microbacia do Ribeirão Salinas, DF 
Figura 16. Mapa geológico da microbacia do Ribeirão Salinas, DF (Fonte: Freitas-Silva e Campos, 1998).

Figura 17. Mapas de pertinência fuzzy reclassificados em potências ordenadas de 2 das classes de solos predeterminadas da microbacia do Ribeirão Salinas, DF

Figura 18. Mapa digital de solos com horizonte B textural e B nítico na microbacia do Ribeirão Salinas, DF 
ANEXO

ANEXO 1 - Descrições Morfológicas. 


\section{PEDOMORFOGEOLOGIA E MAPEAMENTO DIGITAL DE SOLOS COM HORIZONTE B TEXTURAL E B NÍTICO EM UMA ÁREA PILOTO NO PLANALTO CENTRAL DO BRASIL.}

\section{RESUMO GERAL}

A execução de mapeamentos de solos no Brasil é uma demanda permanente na busca de conhecimentos precisos para subsidiar estudos pedogenéticos, planejamento da ocupação racional das terras, para a gestão ambiental e vários outros estudos envolvendo solos. As informações disponíveis acerca dos solos foram geradas em levantamentos realizados, particularmente nas décadas de 70 e 80, em escalas de pouco detalhamento. Uma das alternativas encontradas nas últimas décadas para otimizar os mapeamentos convencionais é o uso de técnicas quantitativas para predição espacial dos solos e de seus atributos, dentre essas técnicas pode-se citar o Mapeamento Digital de Solos. No Distrito Federal (DF), a principal fonte de informação pedológica se encontra em escala 1:100.000, e os dados disponíveis gerados nessa escala não possibilitam uma caracterização detalhada dos solos e o entendimento das relações entre os seus materiais de origem e superfícies geomorfológicas. Diante deste cenário, este trabalho teve como objetivo a geração de um modelo de distribuição de solos na microbacia do Ribeirão Salinas, DF, por meio do estabelecimento das relações entre solos, geologia e geomorfologia (pedomorfogeologia). Mediante análises morfológicas, físicas, químicas, mineralógicas e geoquímicas foram determinadas as classes de solos de ocorrência na microbacia estudada, particularmente solos que apresentam horizonte B textural e B nítico com desenvolvimento de classes de solos de ocorrência restrita no Planalto Central do Brasil. A caracterização e classificação destes solos juntamente com o estabelecimento das relações pedomorfogeológicas permitiram o mapeamento digital dos solos da microbacia do Ribeirão Salinas, DF, empregando a lógica fuzzy.

Palavras Chaves: relação solo-paisagem, pedogênese, pedometria, SIG, lógica Fuzzy. 


\section{PEDOMORPHOGEOLOGY AND DIGITAL MAPPING OF SOILS WITH ARGILLIC HORIZONS IN A PILOT AREA IN CENTRAL BRAZILIAN PLATEAU.}

\section{GENERAL ABSTRACT}

The implementation of soil maps in Brazil is a permanent demand in search of precise knowledge to support pedogenetic studies, planning of land rational occupation , for environmental management and various other studies involving soil. The available information about the soils were generated in surveys done, particularly in the 70s and 80 s in little detail scales. One of the alternatives found in recent decades to optimize conventional mapping is the use of quantitative techniques for spatial prediction of soil and its attributes, among these techniques can cite the Digital Soil Mapping. In the Distrito Federal (DF), the main source of pedological information is in scale 1:100,000, and the available data generated on this scale don't provide a detailed soils characterization and the understanding of the relationships between its source materials and geomorphic surfaces. Against this background, this study aimed to generate a soil distribution model in the Ribeirão Salinas watershed, DF, through the establishment of relationships between soils, geology and geomorphology (pedomorphogeology). By morphological, physical, chemical, mineralogical and geochemical analyzes were determined occurrence of soil classes in the studied area, especially soils with argillic horizons with development of soils classes restricted in the Central Brazilian Plateau. The soils characterization and classification together with the establishment of pedomorphogeological relations allowed the soils digital mapping of Ribeirão Salinas watershed, DF, using fuzzy logic.

Keywords: soil-landscape relationship, pedogenesis, pedometrics, GIS, Fuzzy logic. 


\section{1 - INTRODUÇÃO GERAL}

Com a crescente preocupação ambiental, existe uma necessidade do monitoramento das condições dos recursos naturais. As informações sobre os solos devem ser conciliáveis com essa realidade. Entretanto, para que isso seja possível, é preciso que novos mapeamentos dos recursos naturais, tais como os solos sejam realizados em escalas compatíveis com os objetivos dos trabalhos (Demattê et al., 2004).

O conhecimento sobre as propriedades e os atributos dos solos é de extrema importância para a adoção de práticas adequadas de manejo, visando a sustentabilidade do meio ambiente e maior eficiência na produção de alimentos. Problemas como erosão, contaminação do lençol freático, baixas produtividades em locais de alto potencial produtivo, entre outros fatores de caráter ambiental ou de produção, podem ser evitados ou reduzidos com o uso de informações pedológicas adequadas, obtidas por meio de mapeamentos de solos em escalas adequadas (Arruda et al., 2013).

O uso de técnicas computacionais modernas para análise da distribuição de dados espaciais tem contribuído para maior rapidez e menor custo de execução dos levantamentos de solos, quando comparados aos métodos tradicionais, tornando-os mais quantitativos e possibilitando avaliar as incertezas inerentes às amostragens. Dados de sensoriamento remoto e atributos topográficos de modelos digitais de elevação são amplamente utilizados na compreensão das relações espaciais e temporais, entre classes de solos e componentes da paisagem (Dobos et al., 2000; McBratney et al., 2003; Minasny e McBratney, 2007; McBratney e Voltz, 2007).

No mapeamento de solos por métodos convencionais, o pedólogo acumula conhecimentos a respeito da ocorrência das classes de solos situados em sua região de trabalho, conforme modelos conceituais solo-paisagem. Com esses conhecimentos, esse profissional coleta evidências e gera hipóteses em relação à ocorrência dos solos, confirmando com prospecções de campo. Desta forma, tal como destaca Hudson (1992) o mapeamento tradicional de solos depende da subjetividade do pedólogo e de experiências adquiridas em muitos trabalhos de campo. De maneira semelhante, a inserção de dados quantitativos que expressem os fatores de formação de solos, em sistemas de inteligência artificial, prediz, a partir de um processo de aprendizagem semelhante, essa mesma distribuição dos solos em uma dada região (Zhu, 2000; Chagas et al., 2010, 2011, Arruda et al., 2013). 
Novas abordagens de modelagem quantitativa dos solos têm sido propostas, a fim de descrever, classificar e estudar os padrões de variação espacial dos solos na paisagem, objetivando melhorar o conhecimento da variabilidade espacial dos solos, da precisão e da qualidade da informação, por meio de diversas técnicas quantitativas, chamadas no conjunto, de Pedometria (Webster, 1984).

Assim surgiu o Mapeamento Digital de Solos (MDS), associado aos avanços dos métodos multivariados de classificação e ferramentas computacionais como os Sistemas de Informações Geográficas (SIGs) e o Sensoriamento Remoto (Burrough et al., 1997) O MDS tem como objetivo a criação de sistemas de informações espaciais em solo, por meio do uso de métodos e observações em campo e laboratório, associados a sistemas de inferência espaciais e não espaciais (Lagacherie e McBratney, 2007).

De acordo com Ten Caten et al. (2009) a disponibilização de tecnologias que geram dados sobre os fatores e processos condicionantes do solo, aliada ao emprego de técnicas matemáticas e estatísticas, possibilita que o MDS seja empregado para atender a uma demanda crescente por informação espacial em solos. O MDS tem se valido da disponibilização de tecnologias para a coleta de dados espaciais por intermédio do Sensoriamento Remoto por Radar. O Modelo Digital de Elevação (MDE) gerado a partir do Shuttle Radar Topography Mission (SRTM) vem possibilitando a realização de uma série de estudos, especialmente considerando a utilização do fator "relevo" da equação de Jenny (1941), visando à predição espacial de classes, características e propriedades do solo.

No Distrito Federal (DF), inserido no Planalto Central do Brasil, a principal fonte de informações pedológicas é o Levantamento de Reconhecimento de Solos realizado pela Embrapa (1978), com elaboração de mapa pedológico em escala 1:100.000. Os dados disponíveis gerados nessa escala não possibilitam uma caracterização detalhada dos solos e o entendimento das relações entre os seus materiais de origem e as superfícies geomorfológicas, responsáveis pela distribuição destes na paisagem do DF.

Diante desse cenário, torna-se necessário o mapeamento mais detalhado dos solos do DF para auxiliar estudos pedológicos diversos. Este trabalho objetivou a caracterização detalhada dos solos com horizonte $\mathrm{B}$ textural e B nítico para o mapeamento digital destes solos na microbacia do Ribeirão Salinas, DF, por meio do estabelecimento de relações pedomorfogeológicas. Esta região apresenta litologias diversificadas do Grupo Canastra e Grupo Paranoá, com variação considerável nas 
feições do relevo, que refletem na formação de classes de solos distintas, de ocorrência incomum no Planalto Central do Brasil.

\section{2 - REFERENCIAL TEÓRICO}

\section{1 - Contexto Geológico do Distrito Federal}

No Distrito Federal são reconhecidos quatro conjuntos litológicos no contexto regional da Faixa Brasília, incluindo parte dos grupos Paranoá, Canastra, Araxá e Bambuí (Figura 1), e suas respectivas coberturas de solos residuais ou coluvionares. Os grupos Paranoá e Canastra apresentam idade Meso/Neoproterozóica (1.300 a 1.100 milhões de anos), e os Grupos Araxá e Bambuí, idade Neoproterozóica (950 a 750 milhões de anos) (Freitas-Silva e Campos, 1998).

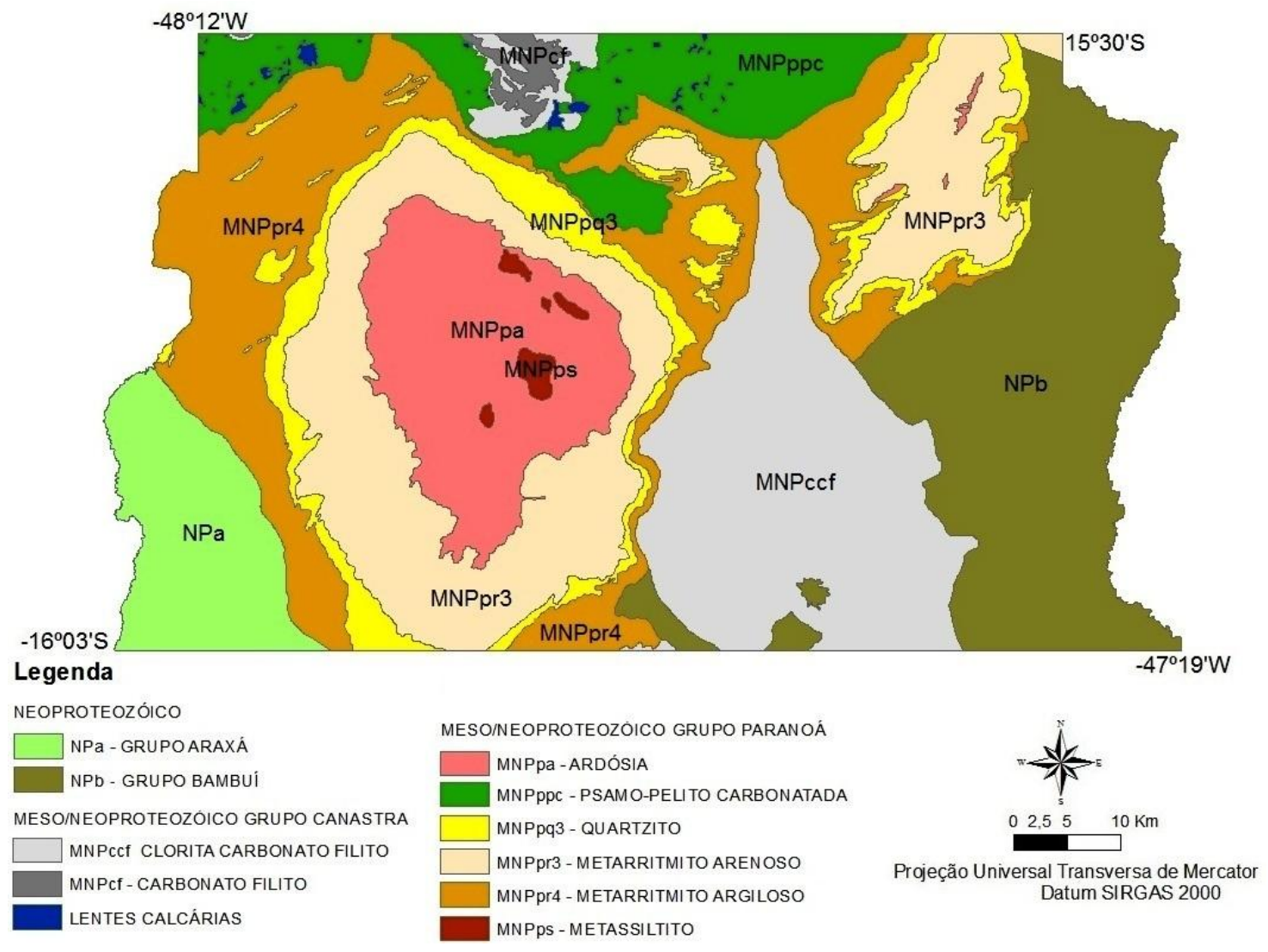

Figura 1. Mapa Geológico do Distrito Federal (Fonte: Freitas-Silva e Campos, 1998).

O Grupo Paranoá ocupa cerca de $65 \%$ da área total do Distrito Federal, e de acordo com Freitas-Silva e Campos (1998) é representado por seis litofácies de sua 
sequência deposicional no DF. Essas litofácies são descritas a seguir, da base para o topo:

Unidade S - Metassiltito Argiloso: composta por um conjunto de metassiltitos argilosos homogêneos com coloração cinza esverdeada a amarelada quando frescos, passando a tons rosados e vermelho-escuros com o aumento da alteração intempérica;

Unidade A - Ardósia: caracterizada por ardósias roxas quando alteradas ou cinza-esverdeadas quando frescas e sempre com aspecto homogêneo;

Unidade R3 - Metarritmito Arenoso: caracterizada por alternâncias de estratos centimétricos a métricos de quartzitos finos a médios com níveis geralmente mais delgados de metassiltitos argilosos, metalamitos siltosos e metalamitos micáceos;

Unidade Q3 - Quartzito Médio: caracterizada por quartzitos finos a médios muito localmente grossos, brancos ou cinza-claros (cinza-escuros quando frescos), bem selecionados, maturos mineralogicamente, em geral muito silicificados e, onde se encontram menos recristalizados, mostram grãos arredondados;

Unidade R4 - Metarritmito Argiloso: representada por um metarritmito homogêneo com intercalações centimétricas regulares de metassiltitos, metalamitos e quartzitos finos que apresentam coloração cinza, amarelada, rosada ou avermelhada em função dos diferentes graus de intemperismo;

Unidade PPC - Psamo-Pelito-Carbonatada: apresenta contato transicional com a unidade sotoposta, sendo marcada pelo aumento progressivo dos metargilitos sobre os quartzitos e metassiltitos. Litologicamente é representada principalmente por metalamitos siltosos de coloração cinza- prateado (que passa a amarelo, rosado ou avermelhado com a alteração) muito laminados, podendo mostrar foliações e, por vezes, com aspecto sedoso ao tato devido à abundante presença de filossilicatos. Além dos metapelitos, ocorrem rochas carbonáticas e quartzíticas.

O Grupo Canastra ocupa cerca de $15 \%$ da área total do DF, sendo distribuído pelos vales dos rios São Bartolomeu (na porção central do DF) e Maranhão (na porção centro-norte do DF). É constituído essencialmente por filitos variados, os quais incluem 
clorita filitos, quartzo-fengita filitos e clorita-carbonato filitos. Além dos filitos ocorrem subordinadamente, na forma de lentes decamétricas, mármores finos cinza-claro e quartzitos finos silicificados e cataclasados.

O Grupo Canastra foi subdividido em quatro formações: Serra do Landim, Paracatu, Serra da Urucânia e Serra da Batalha. A Formação Paracatu comporta dois membros: Morro do Ouro e Serra de Santana (Freitas-Silva e Dardenne, 1994). Destas unidades apenas as formações basais, metassedimentos correlacionáveis às formações Serra do Landim e Paracatu ocorrem no DF (Freitas-Silva e Dardenne 1994).

O Grupo Araxá está limitado ao setor sudoeste do Distrito Federal, ocupando apenas $5 \%$ da área total do território. É composto por xistos variados com ampla predominância de muscovita xistos e ocorrências restritas de clorita xistos, quartzomuscovita xistos, granada xistos e lentes de quartzitos micáceos (Freitas-Silva e Campos, 1998).

Por fim, o Grupo Bambuí se distribui por cerca de $15 \%$ da área total do DF, sendo observado na porção leste ao longo do Vale do Rio Preto. É composto por metassiltitos laminados, metassiltitos argilosos e bancos de arcóseos, com cor de alteração rosada/avermelhada e com cor de rocha fresca em vários tons de verde (Freitas-Silva e Campos, 1998).

\section{2 - Contexto Geomorfológico do Distrito Federal}

O Distrito Federal está localizado no Planalto Central do Brasil, onde se localizam as cabeceiras de afluentes dos três maiores rios brasileiros - o Rio Maranhão (afluente do Rio Tocantins), o Rio Preto (afluente do Rio São Francisco) e os Rios São Bartolomeu e Descoberto (tributários do Rio Paraná). De acordo com Ab'Saber (1977), no contexto regional, o Distrito Federal está inserido no Domínio Morfoclimático do Cerrado cujas características geomorfológicas teriam resultado de uma prolongada interação de regimes climáticos tropical semi-úmido com fatores litológicos, edáficos e bióticos (Campos, 2004).

Codeplan (1984) caracterizou a Compartimentação Geomorfológica do Distrito Federal em dois pediplanos constituídos por superfícies residuais de aplainamento nas cotas mais elevadas; por depressões interplanálticas; e por planícies (Figura 2). 


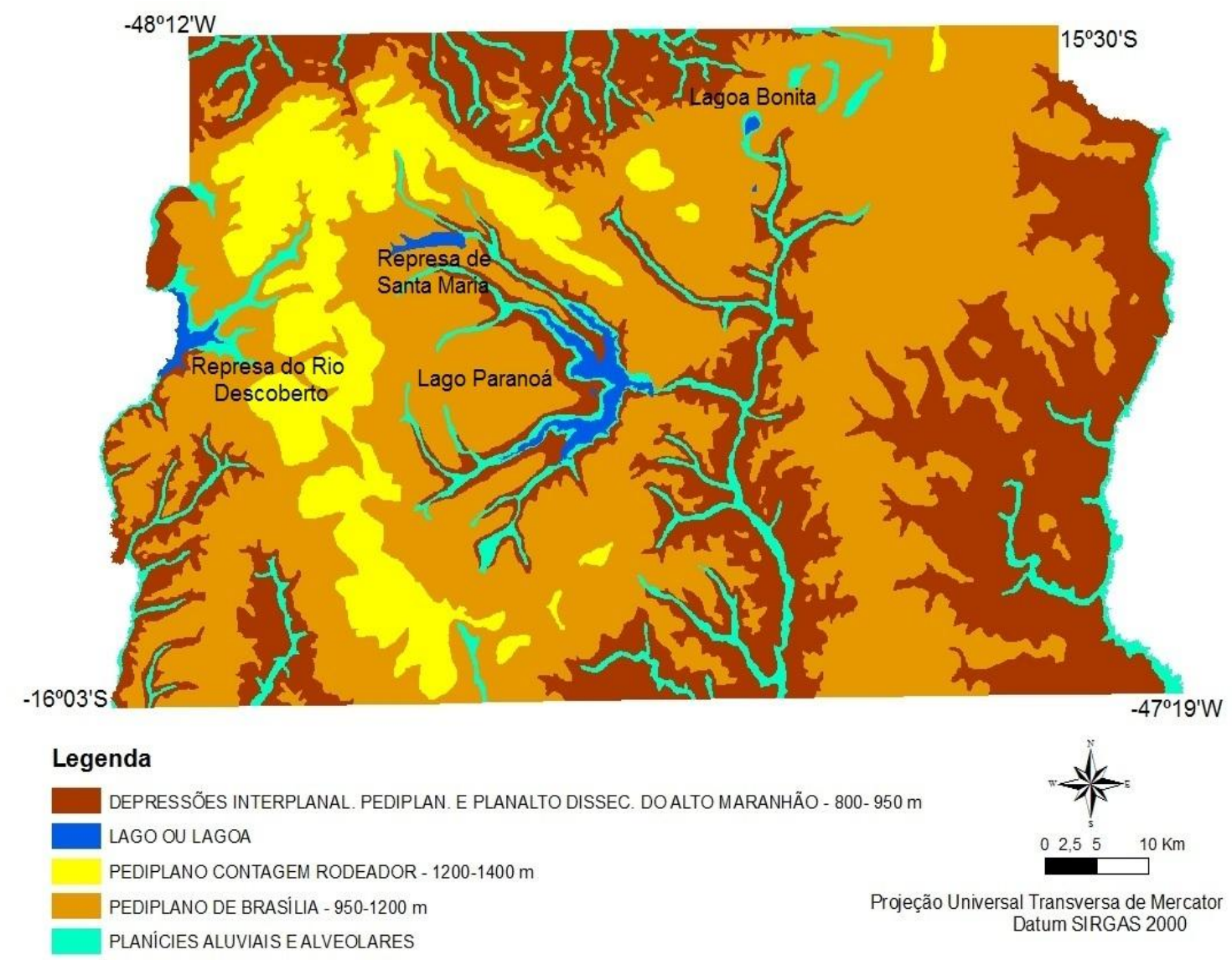

Figura 2. Mapa da Compartimentação Geomorfológica do Distrito Federal (Codeplan, 1984).

O Pediplano Contagem-Rodeador apresenta as cotas mais elevadas, entre 1200 m e 1400 m. Essas áreas são representadas por chapadas, chapadões e interflúvios tabulares.

O Pediplano de Brasília está embutido no Pediplano Contagem-Rodeador por ruptura nítida que aparece na paisagem sob a forma de degraus. Ocupa extensa área com cotas que variam de $950 \mathrm{~m}$ a $1200 \mathrm{~m}$. Da mesma forma que o Pediplano ContagemRodeador, predominam chapadas, chapadões e interflúvios tabulares cobertos por materiais oriundos das áreas mais altas.

As Depressões Interplanálticas e o Planalto Dissecado do Alto Maranhão abrangem áreas menores e mais baixas que os demais compartimentos, com altitudes entre $800 \mathrm{~m}$ e $900 \mathrm{~m}$.

As Planícies Aluviais e Alveolares correspondem às áreas mais baixas e de formação mais recente. O relevo apresenta formas planas elaboradas sobre sedimentos fluviais. 
Penteado (1976) estabeleceu uma Compartimentação Geomorfológica associando as concreções ferruginosas presentes nas superfícies. A Primeira Superfície formada no terciário, com cotas entre 1.050 e 1.300 m (Chapada da Contagem) desenvolveu-se sobre um material mais arenoso, apresentando concreções ferruginosas de dois tipos: lateritos concrecionários e maciços e lateritos pedogenéticos. A Segunda Superfície, chamada de Pediplano de Brasília, situada entre 950 a 1.050 m, foi formada no Eoceno-Oligoceno e apresenta concreções semelhantes às da Primeira, porém os lateritos pedogenéticos dispõem-se sobre um material mais argiloso. A Terceira Superfície, localizada em cotas mais baixas, entre 870 e 950 m, representa áreas mais dissecadas e que estão sofrendo processos erosivos atuais, onde não foram encontradas concreções ferruginosas.

Novaes Pinto (1994) verificou que no Distrito Federal existem três Superfícies Geomorfológicas definidas em: Região de Chapada, Área de Dissecação Intermediária e Região Dissecada de Vale, as quais ocupam 34\%, 31\% e 35\% da área do Distrito Federal, respectivamente.

A Região de Chapada é caracterizada por uma topografia, de plana a plana ondulada, acima da cota $1.000 \mathrm{~m}$. As coberturas são formadas principalmente por couraças vesiculares/pisolíticas e Latossolos.

A Área de Dissecação Intermediária corresponde às áreas fracamente dissecadas, apresentando em seus interflúvios lateritos, Latossolos e colúvios/elúvios delgados com predominância de fragmentos de quartzo.

A Região Dissecada de Vale é representada por depressões ocupadas pelos rios da região.

Martins e Baptista (1998) estudando detalhadamente a evolução geoquímica e geomorfológica dos perfis de intemperismo do Distrito Federal apresentaram uma Compartimentação Geomorfológica para o DF, incluindo os seguintes aspectos para a determinação dos compartimentos: a hipsometria, o padrão de relevo e a declividade. Os compartimentos são denominados de: Planaltos (relevos planos, altitudes acima de $1.135 \mathrm{~m}$ ), Planos Intermediários (formas com diversos graus de dissecação, altitudes de 1.080 a $1.135 \mathrm{~m}$ ) e Planícies (feições de dissecação mais recente, altitudes abaixo de 1.080 m). Além desses, Martins e Baptista (1998) individualizaram os compartimentos de Rebordos (com declividades $<20 \%$ ) e de Escarpas (com declividades $>20 \%$ ). 
Motta et al. (2002) estudou as relações solo-superfície geomórfica e evolução da paisagem em uma área do Planalto Central Brasileiro e propôs a distribuição dos solos da região do Cerrado em três superfícies geomorfológicas.

A primeira superfície corresponde às chapadas atuais, com declives inferiores a 3\%. Seus topos, esculpidos em espessa cobertura de sedimentos terciários (Brasil, 1983), elevam-se entre 1.000 e 1.100 m de altitude, e as bordas, salientes, são recobertas em quase toda a extensão por espessa camada de canga laterítica.

A segunda superfície eleva-se entre 1.000 e $1.100 \mathrm{~m}$ de altitude e se estende na forma de plano inclinado a partir das bordas da primeira em direção aos cursos d'água principais.

A terceira superfície, caracterizada por uma topografia mais acidentada que as anteriores, com predominância de relevos ondulado e forte ondulado, corresponde às áreas de dissecação mais recente.

\section{3 - Contexto Pedológico do Distrito Federal}

O Levantamento de Reconhecimento dos Solos do Distrito Federal realizado pelo Serviço Nacional de Levantamento de Solos (Embrapa, 1978) (Figura 3) mostra que existem duas classes de solos de maior ocorrência na região do Distrito Federal: Latossolos, representado pelos Latossolos Vermelhos (LV) e Vermelho-Amarelos (LVA) e Cambissolos.

Com base no trabalho descrito por Embrapa (1978) e em Martins et al. (2004) observa-se que os Latossolos representam $54,47 \%$ da área do DF divididos em Latossolos Vermelhos (38,63\%) e Latossolo Vermelho-Amarelo (15,84\%). A classe LV ocorre principalmente no topo das chapadas, principais divisores com topos planos, na Depressão do Paranoá e na Bacia do Rio Preto. A classe LVA ocorre principalmente nas bordas de chapadas e divisores, em superfícies planas, abaixo dos topos da chapada da Contagem, sempre adjacente à classe LV. A classe LVA ocorre especialmente no divisor Descoberto-Preto.

A classe Cambissolo (31,02\%) ocorre preferencialmente nas vertentes das bacias mais importantes, do Maranhão, do Descoberto e do São Bartolomeu, além das encostas com declividades mais elevadas na depressão do Paranoá e na Bacia do Rio Preto. 


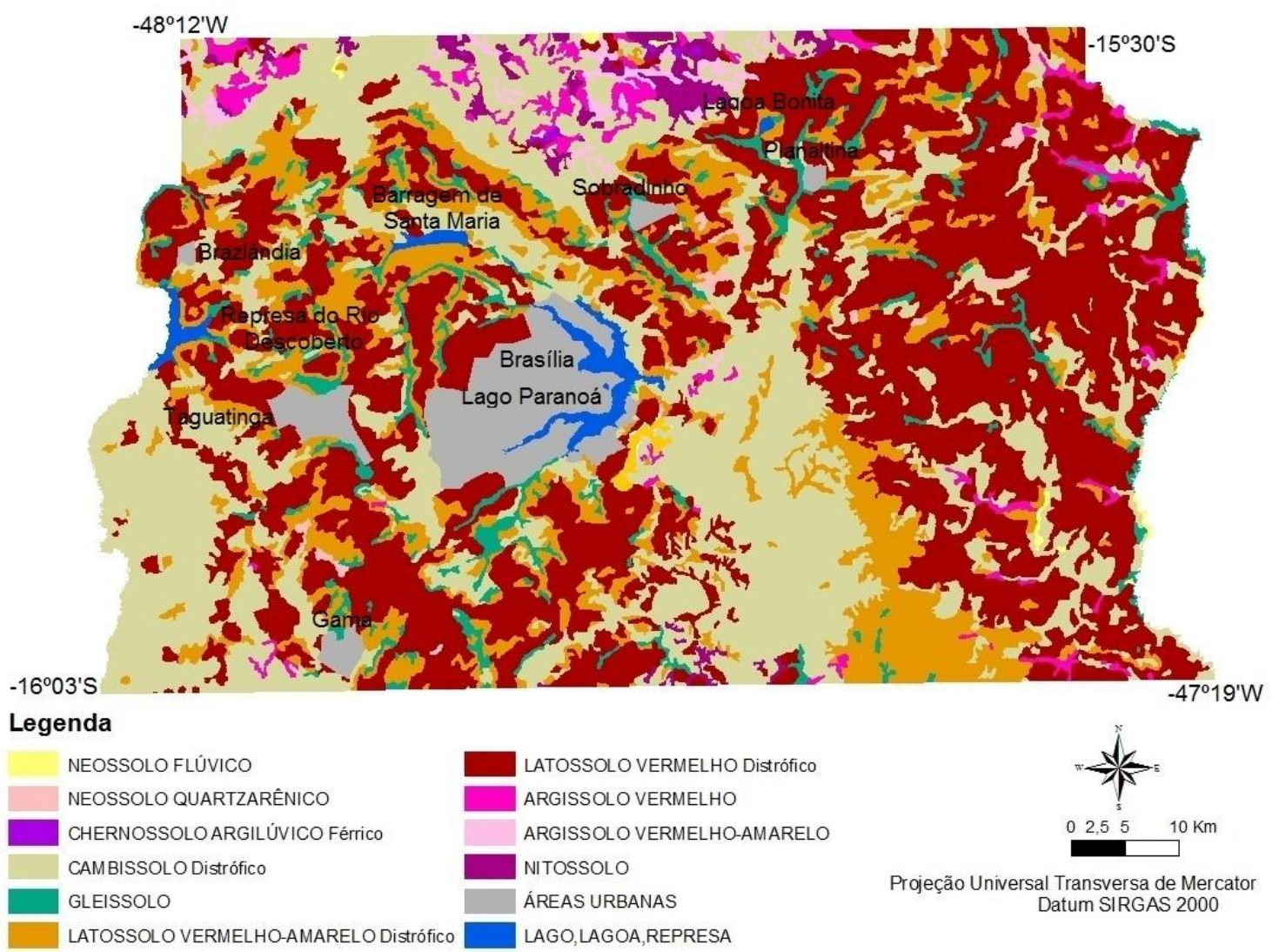

Figura 3. Mapa Pedológico do Distrito Federal (modificado de Embrapa, 1978).

Todas as outras classes que ocorrem no DF cobrem $9,06 \%$ do total, representadas por: Argissolos (4,09\%); Nitossolos (0,09\%); Neossolos Flúvicos (0,19\%); Gleissolos (4,16\%); Neossolos Quartzarênicos $(0,53 \%)$. O restante da área é representado por superfície aquática e áreas urbanas $(5,45 \%)$.

Os Argissolos são mais comuns na Bacia do Maranhão associados aos Chernossolos Argilúvicos e Nitossolos. Os Neossolos Flúvicos ocorrem em porções restritas dos Vales do Rio Preto e Rio Maranhão. Os solos hidromórficos (principalmente os Gleissolos) são importantes ao longo de córregos pequenos e nascentes dos principais rios. A classe Neossolo Quartzarênico é típica do rebordo de chapadas, especialmente sobre quartzitos.

Embrapa (1978), Reatto (2002b), Martins et al. (2004), ZEE (2011) descreveram as principais características das classes de solos de maior ocorrência na região do Distrito Federal: 


\section{Latossolo Vermelho (LV)}

Solos não hidromórficos, com horizonte A moderado e horizonte B latossólico, textura argilosa oumédia e ricas em oxi-hidróxidos de $\mathrm{Fe}$ e Al. São muito porosos, bastante permeáveis e de acentuados a fortemente drenados. Também são álicos e fortemente ácidos.

\section{Latossolo Vermelho-Amarelo (LVA)}

A distinção entre os Latossolos Vermelhos e Vermelho-Amarelos está relacionada à cor do horizonte B. No LVA as cores variam do vermelho ao amarelo, matiz 2,5 YR ou mais amarelado. Alguns perfis podem apresentar caráter concrecionário e plíntico.

\section{Cambissolo (C)}

Classe constituída por solos pouco desenvolvidos, caracterizados por possuírem $\mathrm{B}$ incipiente em que alguns minerais primários facilmente intemperizáveis ainda encontram-se presentes.

\section{Argissolo Vermelho-Amarelo (PVA)}

São solos distróficos ou álicos que apresentam perfil do tipo $\mathrm{A}, \mathrm{Bt}$ e $\mathrm{C}$, com distinta individualização de horizontes. As transições são claras e planas de A para o Bt e gradual e plana do Bt para o C. Essa classe apresenta textura argilosa e média, são solos bem drenados, moderadamente porosos, sobretudo na parte superficial.

\section{Argissolo Vermelho (PV)}

A classe PV ocorre de maneira intermediária, em topossequências, entre a classe Cambissolo, no topo, e a classe Argissolo Vermelho-Amarelo, na base. Localmente ocorrem as classes Nitossolo Vermelho (NV) e Chernossolo Argilúvico (MT) associadas à PVA e PV. Existe grande similaridade com a classe PVA, entretanto apresenta matizes de 2,5 YR ou mais avermelhados.

\section{Solos Hidromórficos (G)}

Os solos hidromórficos incluem as classes Plintossolo e Gleissolo. Esses solos caracterizam-se por apresentar horizonte A bem desenvolvido e processos de redução do Fe em ambientes com elevada atividade da água e baixa drenagem. As estruturas do 
horizonte B geralmente são maciças. O horizonte B da classe Plintossolo apresenta mosqueados e nódulos ferruginosos.

\section{Neossolo Flúvico (RU)}

Desenvolvem-se sobre sedimentos aluviais associados às planícies das principais bacias da região. Geralmente apresentam granulometria arenosa e horizonte A bem desenvolvido.

\section{Neossolo Quartzarênico (RQ)}

Nessa classe os agregados são formados por grãos simples, compostos de quartzo. Em função da fraca estrutura, esses solos são bastante suscetíveis à erosão. Apresenta também elevada permeabilidade e condutividade hidráulica. A espessura é similar à encontrada nos Latossolos.

\section{4 - Relações Solo-Paisagem}

As diferentes feições da superfície terrestre expressas pelo relevo em várias escalas provocam variações nos atributos do solo em magnitudes diferenciadas, dependentes principalmente de um local específico da paisagem (Schoorl et al., 2000).

De acordo com Mulla e McBratney (1999) e Park e Burt (2002), os aspectos topográficos do terreno são os mais importantes indicadores da variação das propriedades do solo. Por sua vez, o entendimento do solo como um corpo natural que possui variação tridimensional e que se origina a partir da inter-relação dos fatores de formação e sob a ação dos processos pedogenéticos, favorece a compreensão da geografia dos solos, assim como a predição do comportamento destes (Bockheim et al., 2005), principalmente em locais onde há variações de material de origem, relevo e tempo. Deve-se ressaltar que a compreensão dessas relações facilita a previsão da ocorrência dos diferentes corpos de solo na paisagem (Young e Hammer, 2000).

De acordo com Ross (2010) a compreensão da relação existente entre os solos e o relevo é fundamental para o entendimento da estrutura, funcionamento e evolução da paisagem. Entender as relações entre os solos e a geomorfologia das vertentes constitui, portanto, um princípio básico para compreender a distribuição espacial dos sistemas pedológicos nas unidades de paisagem, desde os estudos de gênese, evolução vertical e espacial, levantamento e classificação dos solos até aqueles sobre estimativas de erosão, 
todos com a finalidade de auxiliar os projetos de manejo e de planejamento de uso do solo (Campos, 2012).

A identificação do substrato geológico e a sua relação com a paisagem e com os solos oferecem um suporte técnico de grande importância para implantação de sistemas agrícolas com produção sustentável já que o substrato geológico e o relevo influenciam diretamente em processos que podem levar o solo a degradação ambiental quando manejados inadequadamente (Neto et al., 2010).

Segundo Lacerda e Barbosa (2012) avaliações das relações entre geomorfologia, geologia e classes de solos podem permitir a elaboração de modelos preditivos da distribuição dos solos em uma dada paisagem, auxiliando, por sua vez, os trabalhos convencionais de levantamento, mapeamento e classificação de solos.

Trabalhos como o de Lacerda et al. (2005) têm demonstrado a boa correlação entre substrato geológico, relevo e solos formados na região do Distrito Federal. Barbosa et al. (2009) por sua vez,destacaram as relações pedomorfogeológicas nas Chapadas Elevadas do DF, demonstrando a influência do material de origem nas variações das características químicas, físicas e mineralógicas dos solos avaliados. Souza et al. (2013) aplicaram metodologia semelhante a fim de gerar um modelo de distribuição de solos em uma área-piloto do DF, verificando que o modelo gerado apresentou boa correlação entre geologia e geomorfologia.

Teramoto et al. (2001) estabeleceram relações solo, superfície geomórfica e substrato geológico na microbacia do Ribeirão Marins em Piracicaba, SP e observaram que a variabilidade dos atributos químicos e físicos dos solos na camada de 60-80 cm é influenciada principalmente pela natureza química e física do substrato geológico, enquanto os atributos morfológicos são determinados principalmente pelo relevo.

Chicati et al. (2008) realizaram a caracterização de alguns atributos do solo e sua correlação com a paisagem em uma porção do noroeste do Estado do Paraná e constataram que a manipulação dos atributos dos solos coletados em sistema de malha rígida e incorporados em um banco de dados geográficos, além das informações clinográficas, possibilitou a produção do mapa pedológico local com alta precisão. Nesse sentido Rodrigues et al. (2009) estudaram os solos e suas relações com as paisagens naturais no município de Cruz das Almas, BA destacando que as variações geológicas e geomorfológicas da área são determinantes para o desenvolvimento dos solos encontrados. Chagas et al. (2013) relacionaram atributos do terreno, material de origem e solos em uma área do noroeste do Estado do Rio de Janeiro. Segundo estes 
autores a forte influência dos atributos do terreno é bem conhecida na literatura e foi confirmada neste estudo, com os atributos influenciando diferentemente a distribuição dos solos na paisagem.

\section{5 - Geoprocessamento}

O geoprocessamento é uma tecnologia transdisciplinar que por intermédio da localização e do processamento de dados geográficos integra várias disciplinas, equipamentos, programas, processos, entidades, dados, metodologias e pessoas, para coleta, tratamento, análise e apresentação de informações associadas a mapas digitais georreferenciados (Rocha, 2000; Rodrigues et al., 2001).

De acordo com Barbosa (2007) e Silva et al. (2009) os Sistemas de Informações Geográficas - SIG, a geoestatística e o Sensoriamento Remoto constituem a geotecnologia, também denominada de geoprocessamento.

O uso do geoprocessamento tem otimizado a representação cartográfica das relações dos recursos naturais que compõem uma paisagem, auxiliando atividades de levantamentos, mapeamentos, monitoramentos e diagnósticos ambientais (Câmara e Medeiros, 1998).

Segundo Faria et al. (2003) e Lopes et al. (2011) a utilização de softwares de geoprocessamento tem permitido condições para a extração de informações georreferenciadas de parcelas do espaço geográfico a partir do cruzamento e análise de vários mapas temáticos, fornecendo uma visão sobre os diversos componentes do ambiente (solos, geologia, geomorfologia, uso e cobertura vegetal e declividade, entre outros).

Os Sistemas de Informações Geográficas (SIGs), parte integrante das atuais técnicas do geoprocessamento, são destinados à manipulação das informações georreferenciadas (referenciadas espacialmente), oferecendo recursos para armazenamento, gerenciamento, manipulação e análise de dados, e permitindo a geração de produtos como mapas, relatórios e arquivos digitais (Viviani e Manzato, 2005).

De acordo com Nolasco-Carvalho et al. (2009) os projetos desenvolvidos em SIG apresentam, como principal proposta, a combinação de dados espaciais com o objetivo de descrever e analisar interações, de modo a fazer previsões através de 
modelos prospectivos empíricos e fornecer apoio para a definição de classes, unidades ou sítios de interesse.

Os Sistemas de Informações Geográficas manipulam dados de diversas fontes, como mapas planialtimétricos, geomorfológicos, geológicos, produtos de sensoriamento remoto e outros, permitindo combinar informações e efetuar os mais diversos tipos de análises ambientais (Câmara e Medeiros, 1998; Carvalho Junior et al., 2003).

Uma das aplicações de geoprocessamento desenvolvidas em um ambiente SIG é o DTM (Digital Terrain Model) ou MDT (Modelo Digital de Terreno), ou ainda MNT (Modelo Numérico de Terreno) que é definido como uma representação matemática computacional da distribuição de um fenômeno espacial que ocorre dentro de uma região da superfície terrestre. Alguns autores propõem o termo DEM (Digital Elevation Model) como mais apropriado para a representação específica do relevo, visto ser o termo 'terreno' mais abrangente, podendo assim representar outros atributos além da altitude (Burrough, 1986; Felgueiras, 1998; Weibel e Heller, 1999).

As análises desenvolvidas sobre um modelo digital de terreno permitem: visualizar os modelos em projeção geométrica planar; gerar imagens de nível de cinza, imagens sombreadas e imagens temáticas; calcular volumes de aterro e corte; realizar análises de perfis sobre trajetórias predeterminadas e; gerar mapeamentos derivados tais como mapas de declividade, hipsometria, exposição de vertentes, de drenagem, de curva de nível entre outros. Os produtos das análises podem, ainda, serem integrados com outros tipos de dados geográficos objetivando o desenvolvimento de diversas aplicações de geoprocessamento, tais como, planejamento urbano e rural, análises de aptidão agrícola, determinação de áreas de riscos, geração de relatórios de impacto ambiental e outros (Felgueiras, 2005; Sousa Junior e Demattê, 2008).

Outra aplicação do geoprocessamento de grande importância na análise da superfície terrestre é o Sensoriamento Remoto que pode ser definido como uma técnica de se obter informações sobre um determinado objeto, área ou fenômeno, por meio de dados coletados por um equipamento, que não entra em contato direto com o objeto, área ou fenômeno estudado (Landgrebe, 1978; Lillesand e Kiefer, 1987).

Para Demattê et al. (2004) o Sensoriamento Remoto é uma técnica que pode auxiliar o levantamento de solos pelo método tradicional em todos os níveis de aquisição de dados, como o orbital, utilizando-se sensores multiespectrais (TM e ETM do Landsat), multiespectrais (Aster) e de alta resolução espacial (Ikonos); aéreos (fotos aéreas) e videografia. 
Segundo Moreira (2001) e Oka-Fiori et al. (2003) o Sensoriamento Remoto para recursos naturais, tem sido definido de várias maneiras, porém, todas elas expressam um objetivo comum, ou seja: o conjunto de atividades utilizadas para obter informações a respeito dos recursos naturais, renováveis ou não do planeta Terra, por meio de dispositivos sensores dispostos em aviões, satélites ou, até mesmo, na superfície. Contudo, em todas as definições percebe-se claramente que o enfoque maior é a definição de uma nova tecnologia (conjunto de programas e equipamentos colocados à disposição do homem, para auxiliá-lo nas indagações sobre o manejo do meio ambiente).

Por fim, e não menos importante, outra ferramenta de geoprocessamento vem sendo utilizada em ciência do solo - a geoestatística, que por definição é uma metodologia utilizada para o estudo das chamadas variáveis regionalizadas, ou seja, variáveis com condicionamento espacial, as quais têm um comportamento espacial mostrando características intermediárias entre as variáveis verdadeiramente aleatórias e aquelas totalmente determinísticas. Essas variáveis apresentam uma aparente continuidade no espaço, sendo representada por funções numéricas ordinárias que assumem um valor definido a cada ponto no espaço e matematicamente descrevem um fenômeno natural (Landim, 2003)

De acordo com Gontijo (2003) a geoestatística vem despontando como uma alternativa, propondo um método de investigação da dependência espacial e temporal de atributos do solo, e vem sendo bastante empregada na ciência do solo assim como verificado nos trabalhos de Grego e Vieira (2005); Corrêa et al. (2009); Marasca et al. (2011); Valladares (2012); José et al. (2013).

\section{6 - Mapeamento de Solos}

De acordo com Embrapa (1978) os levantamentos de solos têm por finalidade o estudo e a identificação das diferentes classes de solos em uma determinada escala, compreendendo sua distribuição geográfica, delimitação cartográfica e estudo das características físicas, químicas e mineralógicas dos solos, o que possibilita a confecção de mapas pedológicos nas escalas de interesse. Este produto é utilizado para planejamento de uso agrícola sustentável, dele se derivam os mapas técnicos, tais como o de aptidão agrícola das terras, levantamento conservacionista, entre outros, usado 
também para planejamento viário e estudos de geotecnologia, ou seja; estudos pedológicos diversos.

De acordo com Cezar et al. (2007) os levantamentos de solos adequadamente produzidos permitem, seguramente, grande número de informações compatíveis com a escala do levantamento, que apropriadamente manejadas, possibilitam o emprego de técnicas e planejamentos que possam prolongar e até mesmo aumentar a capacidade produtiva das terras.

Usualmente, vários métodos são aplicados na coleta de dados, descrição dos solos no campo e delimitação das unidades de mapeamento. Conforme Embrapa (1978), os mais utilizados são: Método de transeções; Levantamentos de áreas piloto; Estudo de topossequências; Sistema de malhas e Caminhamento livre.

Os levantamentos de solos diferenciam-se, principalmente, quanto aos objetivos a que se destinam e quanto à extensão das áreas que abrangem. A cada tipo de levantamento corresponde a um tipo de mapa ou carta de solos, que é designado pelo mesmo nome do levantamento correspondente. São reconhecidos cinco tipos principais de levantamentos: Exploratório (escala 1:750.000 a 1:2.500.000); Reconhecimento: Baixa Intensidade (escala 1:250.000 a 1:750.000)/Média Intensidade (escala 1:100.000 a 1:250.000)/Alta Intensidade (escala 1:50.000 a 1:100.000); Semidetalhado (escala $\geq$ 1:50.000); Detalhado (escala $\geq 1: 20.000$ ); Ultradetalhado (escala $\geq 1: 5.000$ ) (IBGE, 2007).

\subsection{1 - Mapeamento Tradicional de Solos}

O mapeamento de solos realizado por métodos convencionais é executado com base no modelo solo-paisagem, o que significa dizer que mudanças em um ou mais dos fatores de formação dos solos (clima, organismos, relevo, material de origem, tempo) permitem localizar os limites entre classes de solos diferentes (Coelho, 2010).

Segundo Ranzani (1969) a metodologia tradicional de levantamento de solos se baseia, especialmente, em observações de campo, cujo número, erro e intensidade por área mapeada variam conforme a escala e o nível de detalhamento esperado. Esses métodos são fundamentados em observações pontuais, observações ao longo de transectos que cruzam a paisagem e observações por áreas selecionadas para estudos mais detalhados. A interpretação é tanto mais detalhada quanto melhores as informações disponíveis. 
Tradicionalmente, no mapeamento pedológico é realizada uma avaliação prévia da área a ser mapeada por fotointerpretação ou por outras técnicas que permitem avaliar a sua fisiografia, com auxílio de outros dados do meio físico-biótico disponíveis, com intenso apoio de atividades de caracterização e coleta de solos em campo e de dados analíticos de laboratório. Os mapeamentos tradicionais têm pequeno apoio de técnicas digitais, utilizadas especialmente na sua representação cartográfica (Silva et al., 2013).

O levantamento pedológico tradicional é baseado no modelo discreto e descreve características dos solos de uma determinada área, classifica-os de acordo com um sistema taxonômico vigente, estabelece limites entre classes definidas no mapa e permite fazer inferências sobre o comportamento dos solos quanto ao uso e ao manejo. Ele tem como base o pressuposto de que fatores de formação $(\mathrm{Cl}=$ clima, $\mathrm{O}=$ organismos, $\mathrm{R}=$ relevo, $\mathrm{P}=$ material de origem, $\mathrm{T}=$ tempo) controlam a distribuição dos diferentes solos na paisagem. É reconhecido que características e propriedades dos solos variam espacialmente e que esta variabilidade não é ao acaso e é resultante da atuação do clima e de organismos vivos sobre material de origem de natureza mineral ou orgânica ou a mistura destes, condicionada pelo relevo e pelo tempo (Soil Survey Staff, 1993).

De acordo com Coelho (2010), Sousa Junior e Demattê (2008) e Valladares (2012) o levantamento tradicional de solos é uma atividade bastante onerosa, em termos de tempo e custos, decorrente da qualificação do pessoal que o realiza e dos freqüentes deslocamentos de equipe, o que envolve veículos e combustível, além de análises de solo e outros materiais e serviços. Por outro lado, a crescente preocupação ambiental e o grande desenvolvimento da agricultura, particularmente a de precisão, demandam novos levantamentos de solos em escala mais compatível (Demattê et al., 2004; McBratney et al., 2003) o que torna mais significativa a necessidade de recursos para realização desses trabalhos.

Segundo Mendonça-Santos e Santos (2003) o método tradicional não considera a dependência espacial entre as unidades de mapeamento, a qual pode ser forte, principalmente em se tratando de levantamentos detalhados ou em áreas onde os limites entre os solos não são óbvios. Conseqüentemente, o modelo discreto, assumido no mapeamento tradicional não é geralmente realístico, porque os limites naturais na paisagem tendem a ser mais graduais que abruptos.

Diante desse contexto, cada vez mais é necessário introduzir no levantamento e mapeamento tradicional dos solos, ferramentas que possam auxiliar os procedimentos 
básicos de delimitação cartográfica das unidades de solos (Demattê et al., 2004; Neumann, 2012).

\subsection{2 - Mapeamento Digital de Solos - MDS}

As técnicas e a ciência do MDS busca criar e disponibilizar a informação espacial sobre o solo mediante métodos de observação em campo e laboratoriais, associados a sistemas de inferência com base nos fatores de formação dos solos (McBratney et al., 2003).

Segundo Coelho (2010) uma das primeiras tentativas de modelagem do solo corresponde ao trabalho de Jenny (1941). Este autor desenvolveu uma função que determina a formação dos solos de acordo com a equação 1:

$$
\mathrm{S}=f(\mathrm{cl}, \mathrm{o}, \mathrm{r}, \mathrm{p}, \mathrm{t}) \quad \text { Equação } 1
$$

Onde, o solo (S) é função de clima (cl); organismos (o); relevo (r); material de origem (p) e tempo(t).

Para fins de predição de ocorrência de solo, McBratney et al. (2003) propuseram uma modificação em relação ao modelo de Jenny (1941). Esta modificação inclui dois fatores dos quais o solo pode ser inferido, assim o primeiro novo fator é o espacial (o solo pode ser predito a partir de informações da sua vizinhança) e o segundo é o próprio solo (o solo pode ser predito a partir de seus próprios atributos, ou os atributos podem ser preditos a partir das classes ou outras propriedades), conforme mostrado na equação 2:

$$
\mathrm{Sc}=f(\mathrm{~s}, \mathrm{c}, \mathrm{o}, \mathrm{r}, \mathrm{p}, \mathrm{a}, \mathrm{n})
$$

Equação 2

Desta forma, a classe do solo (Sc) é uma função do solo (s); clima (c); organismos (o); relevo (r); material de origem (p); tempo (a) e posição espacial (n).

Uma das estratégias utilizadas no MDS é a extrapolação das relações solopaisagem de uma área mapeada, definida como área de referência, para regiões onde estas relações ainda não são bem conhecidas. O método baseado na área de referência assume que é possível delimitar pequenas regiões naturais, as quais irão conter um finito número de classes de solos formando um padrão reconhecível e repetidamente 
distribuído. Conseqüentemente, uma área de referência (representativa da região), poderia ser suficiente para identificar todas as classes de solos em áreas maiores e estabelecer suas relações espaciais (Lagacherie, 1995).

Arruda et al. (2013) realizaram o MDS por redes neurais artificiais com base na relação solo-paisagem e observaram que a extrapolação do conhecimento adquirido pela abordagem por redes neurais, a partir de áreas de referência, para áreas adjacentes, gerou resultados coerentes com a realidade de campo. Com isso, unidades de mapeamento foram obtidas em locais não visitados, servindo como dados preliminares para atividades que demandam esse tipo de informação.

Para Coelho e Giasson (2010) a grande vantagem do mapeamento digital de solos é a possibilidade de utilizar a modelagem para extrapolar os limites para áreas adjacentes ao mapa utilizado como referência, partindo da premissa que são áreas de mesma fisiografia, resultando em ganho de informações para áreas que não tinham informações alguma das classes de solos.

Segundo Ten Caten et al. (2012) e Nolasco-Carvalho et al. (2013) no Brasil, o despertar mais recente dos cientistas de solo para o MDS pode estar ligado: (i) à disponibilização bem mais tardia de software e hardware no país; (ii) ao conservadorismo de muitos pedólogos que relutam em utilizar sistemas automatizados capazes de contribuir para o mapeamento de solos; (iii) à carência de pessoal qualificado para o emprego da tecnologia da informação na ciência do solo; (iv) à popularização mais recente no Brasil de tecnologias como sistema de posicionamento global e sensoriamento remoto. Em comparação, o mapeamento de classes de solos empregando técnicas automatizadas já vem sendo praticado há muitos anos em outros países. Webster e Burrough (1972) já demonstraram, há quase quatro décadas, o emprego de estatística multivariada aplicada em sistemas informatizados para mapear classes de solos no sul da Inglaterra.

De acordo com Nolasco-Carvalho et al. (2009) no Brasil a Rede MDS, sob coordenação da Embrapa Solos, vem reunindo pesquisadores que desenvolvem essa área do conhecimento no país. Os trabalhos em MDS ainda são incipientes, mas diferentes autores aplicando redes neurais (Arruda et al., 2013; Chagas et al., 2011; Sarmento, 2010) regressões logísticas múltiplas (Giasson et al. 2006; Ten Caten et al., 2011); árvores de decisão (Crivelenti et al., 2009; Giasson et al., 2011) lógica fuzzy (Nolasco-Carvalho et al., 2009); krigagem (Valladares, 2012; Kraemer, 2007); geotecnologias (Loss et al., 2011; Lópes, 2009; Demattê, 2004; Farias, 2008; Sousa 
Junior e Demattê, 2008) vêm demonstrando a potencialidade dessas técnicas enquanto ferramentas que podem subsidiar a cartografia dos solos.

\subsubsection{1 - Redes Neurais Artificiais}

Uma importante técnica empregada para obter mapas de solos digitais é a abordagem por Redes Neurais Artificiais (RNA). Essas redes realizam processamento de dados de maneira semelhante aos neurônios do cérebro humano (Zhu, 2000), permitindo o estabelecimento de relações matemáticas entre covariáveis ambientais e classes de solos (Coelho e Giasson, 2010).

Segundo Braga et al. (2007); Coelho e Giasson (2010); Arruda et al. (2013) as redes neurais artificiais são sistemas compostos por unidades simples, também denominadas de nodos ou neurônios, dispostos em uma ou mais camadas e interligados por inúmeras conexões, que realizam cálculos de funções determinadas. A rede extrai o poder computacional de sua estrutura paralelamente distribuída e apresenta habilidade de aprender por exemplos e, portanto de generalizar. O termo paralelamente distribuído é utilizado no sentido de que todos os neurônios da camada processam as suas entradas de modo simultâneo independente (Luger, 2004).

Em uma rede neural artificial (RNA) existem "neurônios" para recepção dos dados, outros para o seu transporte e armazenamento, e um terceiro grupo para divulgação externa da informação. As RNAs visam adquirir o conhecimento a partir de exemplos, que podem ser usados para uma predição subseqüiente. Como é necessária a informação a priori para o aprendizado da RNA, esse método é conhecido como aprendizado supervisionado (Key et al., 1989; Zell et al., 1996). De modo geral, o desenvolvimento de um modelo RNA requer a seleção de dados de treinamento, a escolha de uma arquitetura adequada e um exaustivo e cuidadoso processo de treinamento e validação (Boruvka e Penizek, 2007).

De acordo com Chagas et al. (2011) as RNAs tem sido aplicadas na ciência do solo, principalmente para estimativa de atributos do solo.

Chagas et al. (2010) utilizaram atributos topográficos e dados do Landsat7 no MDS com o uso de redes neurais obtendo resultados satisfatórios tanto no processo de treinamento das redes quanto na comparação com pontos de referência de perfis de solo.Em trabalho mais recente Chagas et al. (2011) avaliaram a eficiência dos dados do sensor Quickbird e de atributos do terreno no mapeamento da distribuição dos solos 
utilizando RNA e verificaram que a utilização conjunta desses parâmetros gerou resultados satisfatórios, tanto no processo de treinamento das redes, quanto na comparação com o mapa de solos convencional.

Nesse sentido Arruda et al. (2013) realizaram o MDS por redes neurais artificiais com base na relação solo-paisagem constatando que os atributos do terreno declividade e elevação foram as covariáveis ambientais que mais se destacaram na distinção e predição das classes de solos.

\subsubsection{2 - Árvores de Decisão}

Entre as várias técnicas de extração de dados, os algoritmos de árvores de decisão são utilizados para classificação e predição das amostras desconhecidas por meio de aprendizado do computador, ou seja, com base em registros conhecidos, cria-se um conjunto de treinamento do qual uma árvore de decisão é montada. Dessa árvore, pode-se classificar a amostra desconhecida sem necessariamente testar todos os valores dos seus atributos. A árvore de decisão consiste de uma hierarquia de nós conectados por ramos. O nó interno, também conhecido como decisório ou nó intermediário, é a unidade de tomada de decisão que avalia, por meio de teste lógico, qual será o próximo nó descendente, ou filho. Em contrapartida, um nó externo que não tem nó descendente, também conhecido como folha ou nó terminal, está associado a um rótulo ou valor. Assim, implementa-se um conjunto de dados ao nó inicial da árvore e, dependendo do resultado do teste lógico usado pelo nó, a árvore ramifica-se para um dos nós filhos. Esse procedimento é repetido até que um nó terminal seja alcançado. A repetição desse procedimento caracteriza a recursividade da árvore de decisão (Breiman et al., 1984). O teste lógico que determina a ramificação da árvore é o coeficiente de incerteza da informação, que é baseado na entropia dos dados (Onoda, 2001). A entropia mede a pureza ou impureza dos dados: em um conjunto de dados, a entropia é uma medida da falta de homogeneidade dos dados de entrada em relação à sua classificação, ou seja, quanto menor a entropia, menor a aleatoriedade da variável objetivo.

Giasson et al. (2011) testaram cinco algoritmos de árvores de decisão para o mapeamento digital de solos e indicaram que existem diferenças de desempenho entre os algoritmos de árvore de decisão que devem ser mais intensamente avaliadas no planejamento do MDS. 
Segundo Crivelenti et al. (2009) no caso de mapeamentos, a acurácia geral obtida da análise de árvores de decisão é uma medida simples do total de concordância do mapa predito em relação ao mapa de referência, e a acurácia de classe é essa concordância apenas em relação à classe em consideração.

Crivelenti et al. (2009) trabalharam com mineração de dados para inferência de relações solo-paisagem em MDS constatando que a análise por árvores de decisão associada a sistemas de informações geográficas, permite a elaboração de mapas digitais que representam aproximações dos mapas de solos elaborados por métodos tradicionais.

Em trabalho mais recente Giasson et al. (2013) avaliaram cinco algoritmos de árvores de decisão e três tipos de modelos digitais de elevação para mapeamento digital de solos a nível semidetalhado e concluíram que o mapeamento digital de solos utilizando MDE Aster GDEM e árvore de decisão com algoritmo J48, Simple Tree e BF Tree foi o que produziu modelos de árvore de decisão capazes de produzir mapas de solos com maior semelhança com o mapa de referência.

\subsubsection{3 - Regressão Logística Múltipla (RLM)}

As regressões logísticas múltiplas são regressões nas quais a variável resposta é descontínua ou categórica, ou seja, qualitativa, como por exemplo, classes de solos. As variáveis preditoras do modelo regressional podem ser tanto qualitativas quanto quantitativas, sendo a segunda forma a mais usual (Figueiredo, 2006).

Figueiredo et al. (2008) utilizaram RLM para mapeamento digital de solos no Planalto Médio do Rio Grande do Sul e observaram que essa metodologia adequou-se como método preditivo da distribuição e ocorrência de unidades de mapeamento de solos. Estes autores observaram também que os mapas produzidos apresentaram correspondência somente relativa com os mapas previamente produzidos, utilizando procedimentos tradicionais de levantamento de solos.

Segundo Ten Caten et al. (2011) em casos nos quais onde o resultado de uma inferência pode ser dado sob muitas categorias, denominado de politômico (classes de solo), uma alternativa é trabalhar com a probabilidade de ocorrência de cada uma das categorias, utilizando-se a Regressão Logística Múltipla. De acordo com Hadi e Chatterjee (2006), a Regressão Logística Múltipla não tem qualquer exigência para sua aplicação no que diz respeito à distribuição das variáveis explicativas, não havendo necessidade de ter distribuição normal, correlação linear, medidas em mesma escala ou 
homogeneidade de variância. As variáveis explicativas podem ser ainda, uma mistura de dados contínuos, discretos ou binários.

Ten Caten et al. (2011) avaliaram a utilização de regressões logísticas múltiplas como modelo preditor aplicado ao mapeamento digital de solos e observaram que esse método possibilita a geração de mapas de probabilidade de classes de solo na paisagem além de mostrar-se sensível à proporção relativa das amostras utilizadas indicando que aplicações sistemáticas de RLM ao MDS deverão considerar o agrupamento (associação ou inclusão) das classes de solo pouco representativas.

Ainda segundo estes autores a aplicação de RLM ao mapeamento do solo tem recebido pouco enfoque da pesquisa. No Brasil, constatou-se o uso de RLM em estudos de mapeamentos de solos semidetalhados realizados por Giasson et al. (2006) e Figueiredo et al. (2008). Percebe-se, portanto, que o número de trabalhos é pequeno e existe ainda uma grande lacuna no conhecimento para a aplicação dessas técnicas de modelagem linear generalizada.

\subsubsection{4 - Regressão Linear Múltipla}

A regressão linear múltipla é um método utilizado para modelar a relação linear entre uma variável dependente e uma ou mais variáveis independentes. A análise de regressão, também é usada para entender a relação entre estas variáveis e explorar as formas dessas relações. Em circunstâncias restritas, a análise de regressão é usada para inferir relações causais entre a variável dependente e as variáveis independentes. Um grande número de técnicas para a realização de análise de regressão linear múltipla em mapeamentos digitais de solos tem sido desenvolvido (Berk, 2004).

Valladares e Pereira (2010) realizaram mapeamento e propuseram classes de regime térmico do ar para a classificação dos solos brasileiros em níveis categóricos inferiores utilizando técnicas de geoprocessamento, interpolação, modelo digital de elevação (SRTM) e análise de regressão linear múltipla. Os autores constataram que a metodologia empregada no mapeamento mostrou-se satisfatória, proporcionando uma adequada classificação do regime térmico do ar, baseado na temperatura média e na amplitude térmica. As classes propostas e o mapeamento gerado poderiam ser empregados na classificação dos solos brasileiros.

Neumann (2012) aplicou o modelo de regressão linear múltipla, para o mapeamento de solos, utilizando distintos modelos digitais de elevação, no Distrito 
Federal e avaliou que essa técnica apresentou desempenho satisfatório para mapeamento das classes de solos, Latossolo Vermelho, Latossolo Vermelho-Amarelo e Cambissolo.

\subsubsection{5 - Lógica Fuzzy}

A introdução dos conjuntos Fuzzy para lidar com conceitos inexatos foi primeiramente introduzida por Zadeh (1965). O conjunto Fuzzy é uma metodologia de caracterização de classes, que por várias razões não tem ou não podem definir limites rígidos (bordas) entre as classes. Essas classes definidas de maneira inexata são chamadas de conjuntos Fuzzy. A utilização de um conjunto Fuzzy é indicada sempre que se tiver que lidar com ambigüidade, abstração e ambivalência em modelos matemáticos ou conceituais de fenômenos empíricos (Burrough e McDonnell, 1998).

Silva e Lima (2009) aplicaram a lógica fuzzy no mapeamento de variáveis indicadoras de fertilidade do solo observando que essa metodologia permitiu visualizar as mudanças gradativas das classes de fertilidade do solo o que melhor define zonas de transição gradual ao invés de se classificar as informações em classes definidas de forma exata.

Para Nolasco-Carvalho et al. (2009) a modelagem por Lógica Fuzzy permite simular, por meio do uso de possibilidades, as incertezas e transições tão comuns aos sistemas pedológicos, que é feita correlacionando-se o grau de certeza à experiência e ao conhecimento acumulados do analista; assim, a atribuição dos pesos às possibilidades de ocorrência das classes de solo em determinada área, é totalmente controlada pelo julgamento subjetivo do pedólogo experiente e que detalha um conhecimento profundo sobre a área de estudo. Este tipo de modelagem faz parte da categoria denominada "baseada no conhecimento" e se apresenta como alternativa para operacionalizar os levantamentos de solos.

A fim de proceder à modelagem sob inferência Fuzzy, é necessário que os mapas temáticos (fatores de formação do solo), sejam representados por uma função nebulosa; na prática, isto significa elaborar, para as unidades de solos predefinidas, uma tabela de atributos conferindo-se, para cada classe dos mapas temáticos que serão utilizados no modelo de distribuição dos solos (geologia, vegetação, altitude e declividade), valores entre 0 e 1 ; estes valores constituem o peso que a classe tem e foram determinados de forma subjetiva; por sua vez eles caracterizam o grau de importância de cada classe nos mapas temáticos utilizados no controle da definição da classe de solo. Os valores 
máximos do grau de pertinência de cada conjunto Fuzzy, atribuído a cada mapa, controlam também o peso relativo de cada evidência (fatores de formação do solo) no processo de modelagem (Nolasco-Carvalho et al., 2009).

A lógica Fuzzy, ou lógica nebulosa, tem por objetivo modelar, de modo aproximado, o raciocínio humano, visando manipular informações em um ambiente de incerteza e imprecisão, fornecendo uma resposta aproximada para uma questão baseada em um conhecimento que é inexato, incompleto ou não totalmente confiável (Bönisch, 2004).

Nolasco-Carvalho et al. (2009) utilizaram a lógica fuzzy na avaliação do uso de geotecnologias enquanto instrumento que agiliza a cartografia de solos observando que essa metodologia possibilitou, entre outros fatores, gerar mapas digitais de solos com refinamento da escala e fazer predição de unidades a partir de dados auxiliares (relacionados aos fatores de formação do solo) preexistentes e do conhecimento de especialistas de solos.

Segundo Escada (1998), existem várias funções que podem ser utilizadas para determinar o valor de pertinência das bordas do conjunto Fuzzy. Entre elas pode-se citar a linear, a sigmóide e a quadrática, mais comumente utilizadas em SIGs e assim como em conjuntos Booleanos, dados em conjuntos Fuzzy podem ser manipulados utilizando métodos lógicos para selecionar e combinar dados de vários conjuntos. Vários operadores lógicos podem ser utilizados de forma a se obter um mapa resultante da sobreposição dos vários planos de informação utilizados na modelagem Fuzzy, sendo eles: AND, OR, Soma Algébrica, Produto Algébrico, Operador Gama e Soma Convexa.

Lima (2013) aplicou os métodos semi-automático e lógica fuzzy para o mapeamento de solos da bacia do Sarandi e pôde concluir que a aplicação da lógica fuzzy para o mapeamento de classes de solos possibilitou entre outros fatores: a identificação das classes de solos condizentes com a resolução da base de dados morfométricos utilizada $(30 \mathrm{~m})$, delimitação das unidades de mapeamento com limites semelhantes aos obtidos por metodologia semi-automática, a eliminação de parte da subjetividade no mapeamento.

\subsubsection{Pesos de evidência}

Pesos de Evidência (Weightsofevidence - Woef) é um método quantitativo para combinar evidências em suporte de uma hipótese (Kemp et al., 1999), pertencente a um 
grupo de métodos apropriados para a Tomada de Decisão Multi-Critério (Galvão e Meneses, 2005).

O modelo de Pesos de Evidência é um modelo de predição baseado nos dados que difere de outros modelos de predição baseados no conhecimento. A distinção entre o modelo baseado pelos dados e o modelo baseado pelo conhecimento se manifesta no modelo de Pesos de Evidência que confia na avaliação dos dados de entrada para "estimar a importância relativa das evidências por métodos estatísticos" (Belintani e Meirelles, 2007).

O processo usado na modelagem com Pesos de Evidência constitui, em sua essência, uma versão quantitativa do método de sobreposição e inspeção de diversos mapas temáticos, com vistas à identificação de áreas onde um determinado fenômeno ou evento possa estar presente e coincidente nos mapas temáticos utilizados (Galvão e Meneses, 2005).

O método de Pesos de Evidência assume que para uma região em particular, uma série de mapas binários são conhecidos, e são usados como preditores de um determinado evento. Os mapas preditores binários podem ser usados como mapas de entrada na análise. Assume-se ainda que as localizações de algumas ocorrências são conhecidas (essas ocorrências são chamadas de pontos de treinamento). Os produtos desejados são mapas que mostram a probabilidade de ocorrência do fenômeno pesquisado e a associação da incerteza da probabilidade estimada (Belintani e Meirelles, 2007).

A análise de Pesos de Evidência é uma técnica que envolve processos de correlação e integração entre mapas, o qual é obtido por formulação matemática de probabilidades e pela combinação dessas evidências em suporte a uma hipótese (Boleneus et al., 2001).

Alguns autores vêm utilizando a técnica de pesos de evidência associado aos Sistemas de Informação Geográfica (SIG) para estudos em ciências naturais dentre eles (Asadi e Hale, 2001; Boleneus et al., 2001; Hansen, 2001). No Brasil, existem os trabalhos de Moreira Silva (1999) que utilizou essa técnica na integração de dados geológicos e geofísicos para seleção de alvos para exploração mineral de ouro no Greenstone Belt Rio das Velhas, no quadrilátero ferrífero. E o trabalho de Moreira et al. (2003) que utilizaram o método para modelagem de dados geológicos para aplicação em pesquisa mineral de depósitos radioativos, no Platô de Poços de Caldas - MG e SP. 
Segundo Lima (2013) essa técnica é pouco aplicada em mapeamentos digitais de solos, porém possui um grande potencial para a seleção das variáveis que possuem maior influência sobre o solo, as quais devem ser incluídas no modelo.

\subsubsection{7 - Krigagem}

A krigagem é um processo de estimação de valores de variáveis distribuídas no espaço a partir de valores adjacentes enquanto considerados como interdependentes pelo semivariograma (Landim, 2003).

McBratney (1984) afirma que krigagem apresenta melhores resultados de estimação para valores de variáveis em locais não amostrados do que as técnicas normalmente usadas para classificação de solo. Esta melhoria é atribuída à maneira pela qual as variáveis regionalizadas interpretam a natureza da variação dos muitos atributos, como por exemplo, do solo.

De acordo com Valladares (2012) a modelagem geoespacial permite a descrição quantitativa da variabilidade espacial dos atributos dos solos e a estimativa não tendenciosa da variância mínima de valores desses atributos em locais não amostrados. Acessar essa variabilidade faz da geoestatística uma eficiente ferramenta de suporte a decisão de amostragem para monitoramento de variáveis dependentes espacialmente (Druck et al., 2004). As intervenções para corrigir variações indesejáveis de atributos do solo podem ser baseadas em mapas de isolinhas das variáveis dependentes espacialmente. A geoestatística pode ser uma importante ferramenta na caracterização e mapeamento de atributos dos solos (Kumar et al., 2012) em áreas extensas e com dados escassos. Há algumas décadas já se tem conhecimento da utilidade do mapeamento de atributos dos solos com o uso da krigagem (Odeh et al., 1995; Walter, et al., 2001), técnica que pode auxiliar nos mapeamentos pedológicos.

Mais recentemente Kraemer (2007) estudou a variabilidade espacial dos atributos do solo na delimitação das unidades de mapeamento utilizando, entre outros métodos, a krigagem e verificou que os resultados obtidos por essa metodologia permitem entender e visualizar a variabilidade dos atributos do solo. 


\section{3 - OBJETIVOS}

\section{1 - Objetivo Geral}

O presente estudo tem como objetivo geral a caracterização detalhada de solos com horizonte B textural e B nítico na microbacia do Ribeirão Salinas, DF, visando o mapeamento digital destes solos, por meio de modelagem embasada no estabelecimento das relações entre solos, geologia e geomorfologia (pedomorfogeologia), utilizando a lógica fuzzy.

\section{2 - Objetivos Específicos}

- Caracterizar os solos, particularmente os que apresentam horizonte B textural e B nítico, em geo-topossequências representativas da distribuição pedológica na superfície geomorfológica mais recente do DF - Terceira Superfície, representada pela microbacia do Ribeirão Salinas, DF.

- Definir as relações entre solos, geologia e geomorfologia na microbacia do Ribeirão Salinas, DF, assim como avaliar a filiação pedogenética das classes de solos de ocorrência restrita no Planalto Central do Brasil.

- Estabelecer o modelo de distribuição dos solos da área de estudo, por meio do estabelecimento das relações pedomorfogeológicas, para realizar o mapeamento digital de solos com emprego da lógica fuzzy.

- Validação do mapa pedológico gerado.

\section{4 - REFERÊNCIAS BIBLIOGRÁFICAS}

AB'SABER, A.N. Os domínios morfoclimáticos na América do Sul: Primeira aproximação. Geomorfologia, São Paulo, v. 52, p. 17-28, 1977.

ARRUDA, G. P.; DEMATTÊ, J. A. M.; CHAGAS, C. S. Mapeamento Digital de Solos por Redes Neurais Artificiais com base na relação solo-paisagem. Revista Brasileira de Ciência do Solo, v.37, p. 327-338, 2013.

ASADI H, H.; HALE, M. A predictive GIS model for potential mapping of gold and base metal mineralization in Takabarea, Iran. Computers \& Geosciences, v. 27, p.901-912, 2001. 
BARBOSA, I. O. Distribuição dos solos nas chapadas elevadas do Distrito Federal, com emprego de geoprocessamento. 2007. 125p. Dissertação (Mestrado). Faculdade de Agronomia e Medicina Veterinária, Universidade de Brasília, Brasília, 2007.

BARBOSA, I. O.; LACERDA, M. P. C.; BILICH, M. R. Relações pedomorfogeológicas nas Chapadas Elevadas do Distrito Federal. Revista Brasileira de Ciência do Solo, v. 33, p.273-283, 2009.

BELINTANI, H; MEIRELLES, M. S. P. Integração temática de dados espaciais para avaliação do processo de erosão em bacias hidrográficas. In: Simpósio Brasileiro de Recursos Hídricos, 17, 2007, São Paulo. Anais...São Paulo, 2007. 24p.

BERK, A. R. Regression Analysis: A constructive Critique. London: Sage Publications, 2004.

BOCKHEIM, J. G.; GENNADIYEV, A. N.; HAMMER, R. D.; TANDARICH, J. P. Historical development of key concepts in pedology. Geoderma, Amsterdam, v. 124, n.1, p.23-36, 2005.

BOLENEUS, D. E.; RAINES, G. L.; CAUSEY, J. D.; BOOKSTROM, A. A.; Frost, T. P.; Hyndman, P. C. Assessment method for epithermal gold deposits in northeast Washington State using weights-of-evidence GIS modeling. Washington, D. C.: United States Geological Survey, 2001. p.501, 502. (OpenFile-Report 01).

BÖNISCH S.; LOPES ASSAD, M. L.; MONTEIRO, A. M. V.; G. CÂMARA Representação e propagação de incertezas em dados de solo. II - Atributos numéricos (1). Revista Brasileira de Ciência do Solo, v.28, n.1, p. 33-47, 2004.

BORUVKA, L.; PENIZEK, V. A test of an artificial neural network allocation procedure using the Czech soil survey of agricultural land data. In: LAGACHERIE, P.; BRAGA, A. P.; LUDEMIR, P. D. ; CARVALHO, A. P. L. F. Redes Neurais Artificiais: teoria e aplicações. LTC, Rio de Janeiro, 2 ed., 2007. $226 \mathrm{p}$.

BRAGA, A. P.; LUDERMIR, T. B.; CARVAlHO, A. P. L. F. Redes Neurais Artificiais: teoria e aplicações. 2007. LTC, Rio de Janeiro, 2 ed, 226 p.

BREIMAN, L.; FRIEDMAN, J.H.; OLSHEN, R.A.; STONE, C.J. Classification and regression trees. Monterey: Wadsworth and Brooks, 1984. 358p.

BURROUGH, P. A.; MCDONNELL, R. A. Principles of Geographic Information Systems. Oxford: Oxford University Press, 1998. 333 p. 
BURROUGH, P.A. Principles of geographical information systems for land resource assessment. New York, Oxford University Press, 1986. 194p.

BURROUGH, P.A., VAN GAANS, P.F.M., HOOTSMANS, R., 1997. Continuous classification in soil survey: spatial correlation, confusion and boundaries. In: De GRUIJTER, J.J., McBRATNEY, A.B., McSWEENEY, K. (Eds.), Fuzzy Sets in Soil Science. Geoderma, v.77, p115-135.

CÂMARA, G.; MEDEIROS, J. S. Geoprocessamento para Projetos Ambientais. São José dos Campos, 2ed, 1998.

CÂMARA, G.; MOREIRA, F.R.; BARBOSA, C.; FILHO, R. A.; BONISCH, S. Inferência Geográfica e Suporte à Decisão. São José dos Campos: INPE, 2001.Disponívelem:<http://64.233.169.104/search?q=cache:EQYHIDcZp8gJ:mt cm12.sid.inpe.br/col/sid.inpe.br/sergio/2004/04.19.15.04/doc/cap9inferencia.pdf + Infer\%C3\%AAncia+geogr\%C3\%A1 fica+e+suporte+\%C3\%A0+decis\%C3\%A 3o\&hl=ptBR\&ct=clnk\&cd=3\&gl=br $>$. Acesso em: 16/01/2014.

CAMPOS, M. C. C. Relações solo-paisagem: conceitos, evolução e aplicações. Revista Ambiência, v.8, n.3, p.963-982, 2012.

CAMPOS, J.E.G. Hidrogeologia do Distrito Federal: bases para a gestão dos recursos hídricos subterrâneos. Revista Brasileira de Geociências, v.34, n.1, p.41-48, 2004.

CARVALHO JUNIOR, W.; CHAGAS, C. S. PEREIRA, N. R.; STRAUCH, J. C. M. Elaboração de zoneamentos agropedoclimáticos por geoprocessamento: soja em municípios do Rio Grande do Sul. Revista Brasileira de Ciência Solo, v.27, n.2, 2003.

CEZAR, E.; NANNI, M.R.; CHICATI, M.L. Comparação de três levantamentos de solos independentes por meio de Sistema de Informações Geográficas. In: Simpósio Brasileiro de Sensoriamento Remoto, 13, 2007, Florianópolis, Anais... Florianópolis, INPE, 2007. p.119-124.

CHAGAS, C.S.; CARVALHO JÚNIOR, W.; BHERING, S.B. Integração de dados dos quickbirde atributos do terreno no mapeamento digital de solos por redes neurais artificiais. Revista Brasileira de Ciência do Solo, v. 35, p.693-704, 2011.

CHAGAS, C.S.; FERNANDES FILHO, E.I.; VIEIRA, C.A.O.; SCHAEFER, C.E.G.R.; CARVALHO JÚNIOR, W. Atributos topográficos e dados do Landsat7 no mapeamento digital de solos com uso de redes neurais. Pesquisa Agropecuária Brasileira, v.45, n.5, p. 497-507, 2010. 
CHAGAS, C.S.; FERNANDES FILHO, E.I.; BHERING, S. B. Relação entre atributos do terreno, material de origem e solos em uma área no noroeste do estado do Rio de Janeiro. Sociedade \& Natureza., Uberlândia, v. 25, n.1, p.147-162, 2013.

CHICATI, M. L.; NANNI, M. R.; CÉZAR, E.; DEMATTÊ, J. A. M.; OLIVEIRA, R. B. Caracterização de alguns atributos do solo e sua correlação com a paisagem em uma porção do noroeste do Estado do Paraná. Acta Scientiarum Agronomy, Maringá, v.30, supl., p.719-724, 2008.

CODEPLAN. Companhia de Planejamento do Distrito Federal. Atlas do Distrito Federal. Brasília, CODEPLAN, 1984.

CODEPLAN. Companhia de Planejamento do Distrito Federal. GeoServiço. Disponível em: $\quad$ http://ortofoto.mapa.codeplan.df.gov.br/demo/tms $>$. Acesso em: 02/02/2015.

COELHO, F. F. Comparação de métodos de mapeamento digital de solos através de variáveis geomorfométricas e Sistema de Informações Geográficas. 2010. 95 p. Dissertação (Mestrado). Centro Estadual de Pesquisas em Sensoriamento Remoto e Meteorologia, Universidade Federal do Rio Grande do Sul, Porto Alegre. 2010.

COELHO, F.F.; GIASSON, E. Métodos para mapeamento digital de solos com utilização de sistema de informação geográfica. Ciência Rural, v. 40, p.0992106, 2010.

CORRÊA, A. N.; TAVARES, M. H. F.; URIBE-OPAZO, M. A. Variabilidade espacial de atributos físicos do solo e seus efeitos sobre a produtividade do trigo. Ciências Agrárias, Londrina, v. 30, n. 1, p. 81-94, 2009.

CRIVELENTI, R.C.; COELHO, R. M.; ADAMI, S. F.; ROBSON, S.; OLIVEIRA, M. Mineração de dados para a inferência de relações solo-paisagem em mapeamentos digitais de solo. Revista Agropecuária Brasileira, v.44, n.12, p.1707-1715, 2009.

DEMATTÊ, J. A. M.; GENÚ, A. M.; FIORIO, P. R.; ORTIZ, J. L.; MAZZA, J. A.; LEONARDO, H. C. L. Comparação entre mapas de solos obtidos por sensoriamento remoto espectral e pelo método convencional. Pesquisa Agropecuária Brasileira, v.39, n.12, 2004.

DOBOS, E.; MICHELI, E.; BAUMGARDNER, M. F.; BIEHL, L.; HELT, T. Use of combined digital elevation model and satellite radiometric data for regional soil mapping. Geoderma, v.97, p.367-391, 2000. 
DRUCK, S.; CARVAlHO, M.S.; CÂMARA, G.; MONTEIRO, A.V.M. Análise Espacial de Dados Geográficos. Brasília: EMBRAPA, 2004. 209p.

EMBRAPA - Empresa Brasileira de Pesquisa Agropecuária - Serviço Nacional de Levantamento e Conservação de solos. Boletim Técnico $n^{\circ} 53$. Levantamento de Reconhecimento dos solos do Distrito Federal, Rio de Janeiro, Embrapa, 1978. 466p.

ESCADA, M. I. S. Aplicação de técnica Fuzzy em SIG como alternativa para o Zoneamento Ecológico Econômico (ZEE). INPE, São José dos Campos, 1998.

FARIA, A. L. L.; SILVA, J. X.; GOES, M. H. B. Análise ambiental por geoprocessamento em áreas com suscetibilidade à erosão do solo na bacia hidrográfica do ribeirão espírito santo, Juiz de Fora - MG. Revista Caminhos da Geografia, v. 4, p.50-65, 2003.

FARIAS, M. F. R.. Integração de parâmetros morfométricos e interpretação de imagens orbitais para o auxílio no mapeamento de solos no Parque Nacional de Brasília. 2008. 136p. Dissertação (Mestrado). Universidade de Brasília/GEA, Brasília. 2008.

FELGUEIRAS, C. A. "Modelagem Numérica de Terreno". In: CÂMARA, G.; MEDEIROS, J. S. (eds.). “Geoprocessamento para Projetos Ambientais". São José dos Campos: INPE, cap. 4, p. 4-1 - 4-38, 1998.

FELGUEIRAS, C. A. Análises sobre Modelos Digitais de Terreno em ambiente de Sistemas de Informações Geográficas. São José dos Campos, SP. Divisão de Processamento de Imagens - DPI, Instituto de Pesquisas Espaciais - INPE, 2005.

FIGUEIREDO, S. R. Mapeamento supervisionado de solos através do uso de regressões logísticas múltiplas e sistema de informações geográficas. 2006. 104p. Dissertação (Mestrado). Universidade Federal do Rio Grande do Sul, Porto Alegre. 2006.

FIGUEIREDO, S. R.; GIASSON, E.; TORNQUIST, C. G.; NASCIMENTO, P. C. Uso de regressões logísticas múltiplas para mapeamento digital de solos no Planalto Médio do RS. Revista Brasileira de Ciência do Solo, v. 35, n. especial, p. 2779-2785, 2008.

FREITAS-SILVA, F. H.; CAMPOS, J. E. G. Geologia do Distrito Federal. In: CAMPOS, J. E. G.; FREITAS-SILVA, F. H., coords. Inventário hidrogeológico 
e dos recursos hídricos superficiais do Distrito Federal. Brasília, SEMATECIEMA-MMA-SRH, 1998. CD-ROM.

FREITAS-SILVA, F. H.; DARDENNE, M. A. 1994. Proposta de subdivisão estratigráfica formal para o grupo Canastra no oeste de Minas Gerais e leste de Goiás. In: Simpósio Geológico do Centro Oeste, 2007, Brasília. Anais... Brasília, 1994. p.164-165.

GALVÃO, W. S.; MENESES, P. R. Identificação de variáveis geoambientais preditivas ao processo de locação de estações fluviométricas com o apoio do Modelo de Pesos de Evidência. In: Simpósio Brasileiro de Sensoriamento Remoto, Goiânia, 12, 2005, Anais... Goiânia, INPE, 2005. p.2169-2176.

GIASSON, E.; CLARKE, R.T.; INDA JUNIOR, A.V.; MERTEN, G.H.; TORNQUIST, C.G. Digital soil mapping using multiple logistic regression on terrain parameters in southern Brazil. Scientia Agricola, v.63, p.262-268, 2006.

GIASSON, E.; SARMENTO, E. C.; WEBER, E.; FLORES, C. A.; HASENACK, H. Decision trees for digital soil mapping on subtropical basaltics teeplands. Scientia Agricola, v.68, n.2, p.167-174, 2011.

GIASSON, E.; HARTEMINK, A.E.; TORNQUIST, C.G.; TESKE, R.; BAGATINI, T. Avaliação de cinco algoritmos de árvores de decisão e três tipos de modelos digitais de elevação para mapeamento digital de solos a nível semidetalhado na Bacia do Lageado Grande, RS, Brasil. Ciência Rural, v.43, p.61-67, 2013.

GONTIJO, I. Avaliação de atributos físicos em solos de cerrado sob cafeicultura em dois sistemas de manejo de plantas espontâneas, utilizando testes de hipóteses e geoestatística. 2003. 86p. Dissertação (Mestrado). Universidade Federal de Uberlândia, Uberlândia. 2003.

GREGO, C. R.; VIEIRA, S. R. Variabilidade espacial de propriedades físicas do solo em uma parcela experimental. Revista Brasileira de Ciência do Solo, v.29, p. 169-177, 2005.

HADI, A. S. CHATTERJEE, S. Regression analysis by example. 4.ed. New York: John Willey \& Sons, Inc. 2006. 375p.

HANSEN; D.T. 2001. Describing GIS applications: spatial statistics and weight evidence extension to ArcView in the analysis of the distribution archaeology sites in Landscape. In: GISCAFE. Disponível em:<http://www.giscafe.com/TechPapers/Papers/ paper054/>.Acesso em: 15/09/2014. 
HUDSON, B. D. The soil survey as paradigm-based science. Soil Science Society of America Journal, v.56, p.836-841, 1992.

IBGE - Instituto Brasileiro de Geografia e Estatística. Manual técnico de pedologia. Rio de Janeiro, IBGE - Coordenação de Recursos Naturais e Estudos Ambientais, Manuais técnicos de geociências, ISSN 0103-9598, nº, 2007. $323 \mathrm{p}$.

JENNY, H. Factors of soil formation, a system of quantitative pedology. McGrawHill: New York, 1941. 281 p.

JOSÉ, J. V.; REZENDE, R.; FREITAS, P. S. L.; HONGYU, K.; PERBONI, A. MARQUES, P. A. A.; DIAS, C. T. S.; COELHO, R. D. Análise multivariada e geoestatística de variáveis físico-hídricas de diferentes solos. Water Resources and Irrigation Management, v.2, n.3, p.121-129, 2013.

KEMP, L. D.; BONHAM-CARTER, G. F.; RAINES, G. L. (1999) Arc-WofE: Arcview extension for eights-of-evidence mapping. Geolagical Survey of Canada, United States of Geological Survey. User Guide, 76 p. Disponível em: http://gis.nrcan.gc.ca/software/arcview/wofe. Acesso em: 04/01/2014.

KEY, J.; MASLANIK, J.A.; SCHWEIGER, A.J. Classification of merged AVHRR and SMMR artic data with neural networks. Photogrammetric Engineering and Remote Sensing, v.55, p.1331-1338, 1989.

KRAEMER G. B. Variabilidade espacial dos atributos do solo na delimitação das unidades de mapeamento. 2007. 87p. Dissertação (Mestrado). Universidade Federal do Paraná, Curitiba, 2007.

KUMAR, S.; LAL, R.; LIU, D.A geographically weighted regression kriging approach for mapping soil organic carbon stock. Geoderma, v.189-190, 627-634, 2012.

LACERDA, M. P. C.; BARBOSA, I. O. Relações pedomorfogeológicas e distribuição de pedoformas na Estação Ecológica de Águas Emendadas, Distrito Federal. Revista Brasileira de Ciência do Solo, v. 36, p.709-721, 2012.

LACERDA, M. P. C.; BARBOSA, I. O.; MENESES, P. R.; ROSA, J. W. C.; ROIG, H. C. Aplicação de geotecnologias em correlações entre solos, geomorfologia, geologia e vegetação nativa no Distrito Federal. In: Simpósio Brasileiro de Sensoriamento Remoto, Goiânia, 12, 2005. Anais... Goiânia, 2005. p.2211-2218.

LAGACHERIE, P. A soil survey procedure using the knowledge of soil pattern established on a previously mapped reference area. Geoderma, v.65, n.3-4, p.283-301, 1995. 
LAGACHERIE, P.; MCBRATNEY, A. B. Spatial soil information systems and spatial soil inference systems: perspectives for digital soil mapping. In: LAGACHERIE, P. et al. Digital soil mapping: an introductory perspective. Amsterdam: Elsevier, 2007, Cap. 1, p.3-22.

LANDGREBE, D.A. The Quantitative Approach: Concept and Rationale. In: SWAIN, P. H; DAVIS, S.M. Remote Sensing: The Quantitative Approach. New York: McGRAW-HILL, p.1-20, 1978.

LANDIM, P.M.B. Análise estatísitica de dados geológicos. $2^{\text {a }}$. Edição, São Paulo: Editora Unesp, 2003. 253p.

LILLESAND, T. M.; KIEFFER, R. W. Remote Sensing and Image Interpretation. 2 ed. New York, John Wiley\& Sons, 1987. 721p.

LIMA, L. A. S. Aplicação dos métodos semi-automático e lógica fuzzy para o mapeamento de solos da bacia do Sarandi. 2013. 124 p. Dissertação (Mestrado). Universidade de Brasília, Brasília. 2013.

LOPES, F. B.; ANDRADE, E. M.; TEIXEIRA, A. S.; CAITANO, R. F.; CHAVES, L. C. G. Uso de geoprocessamento na estimativa da perda de solo emmicrobacia hidrográfica do semiárido brasileiro. RevistaAgro@mbiente On-line, v. 5, n. 2, p.88-96, 2011.

LÓPEZ, L. R. Pedologia quantitativa: espectrometria VIS-NIR-SWIR e mapeamento digital de solos. 2009. 171 p. Dissertação (Mestrado). Escola Superior de Agricultura Luiz de Queiroz, Piracicaba. 2009.

LOSS, A.; CHAVES, A. C.; BERNINI; T. A.; COUTO, W. H. do; MIGUEL, D. L.; FRANCELINO, M. R.; ANJOS, L. H. C. dos. Aplicação de modelo digital de elevação para o levantamento de solos da microbacia do rio Bengala, Cachoeiras de Macacu, RJ, Brasil. Revista de Ciencia y Tecnología da América, Interciência, v. 36, n.2, p. 121-127, 2011.

LUGER, G. F. Inteligência Artificial: estruturas e estratégias para a solução de problemas complexos. Bookman, Porto Alegre. 4 ed. 2004.

MARASCA, I.; OliVEIRA, C. A. A.; GUIMARÃES, E. C.; CUNHA, J. P. A. R.; ASSIS, R. L.; PERIN, A.; MENEZES, L. A. S. Variabilidade espacial da resistência do solo à penetração e teor de água em sistema de plantio direto, na cultura da soja. Bioscience Journal, Uberlândia, v. 27, n. 2, p. 239-246, 2011.

MARTINS, E. S.; BAPTISTA, G. M. M. Compartimentação geomorfológica e sistemas morfodinâmicos do Distrito Federal. In: Inventário hidrogeológicos e 
dos recursos hídricos superficiais do Distrito Federal. Brasília, IEMA/SEMATEC/UnB, 1998. v.1, p 89 - 137.

MARTINS, E. S.; REATTO, A.; CARVALHO JR, O. A.; GUIMARÃES, R. F. Evolução Geomorfológica do Distrito Federal. Planaltina, DF: Embrapa Cerrados, 2004. 57 p. - Documentos/Embrapa Cerrados, ISSN 1517-5111; n. 122.

McBRATNEY, A.B. Geoestatistical soil survey. 1984. 250 p. Ph.D. Thesis Department of Soil Science, University of Aberdeen.

McBRATNEY, A. B.; SANTOS, M. L. M.; MINASNY, B.On digital soil mapping. Geoderma. Amsterdam, v.117, p. 3-52, 2003.

McBRATNEY, A.B.; VOLTZ, M., eds. Digital soil mapping: An introductory perspectives. Amsterdam, Elsevier, p.415-424, 2007 (Developments in Soil Science, 31).

MENDONÇA-SANTOS M. L.; SANTOS H. G. dos. Mapeamento Digital de Classes e Atributos de Solos métodos paradigmas e novas técnicas. Rio de Janeiro, RJ. 2003 (Embrapa Solos. Documentos, 55). Disponível em: <http://www.cnps.embrapa.br

MINASNY, B.; MCBRATNEY, A.B. Incorporating taxonomic distance into spatial prediction and digital mapping of soil classes. Geoderma. v.142, p.285-293. 2007.

MOREIRA SILVA, A. Integração de dados geológicos e geofísicos utilizando-se de uma nova técnica estatística para seleção de alvos para exploração mineral, aplicada ao Greenstone Belt Rio das Velhas, Quadrilátero Ferrífero. 1999. 195p. Tese (Doutorado). Instituto de Geociências, Universidade de Brasília, Brasília. 1999.

MOREIRA, F. R. S.; ALMEIDA FILHO, R. A.; CÂMARA G. Modelamento de dados geológicos em pesquisa mineral segundo o teorema de Bayes. In: Simpósio Brasileiro de Sensoriamento Remoto, Belo Horizonte, 11, 2003. Anais... Belo Horizonte, INPE, 2003. p.895-902.

MOREIRA, M. A. 2001. Fundamentos do Sensoriamento Remoto. São José dos Campos: INPE, 1 ed., 250p.

MOTTA, P. E. F. DA; CARVALHO FILHO, A.; KER, J.; PEREIRA, N.; CARVALHO JUNIOR, W.; BLANCANEAUX, P. Relações solo-superfície geomórfica e 
evolução da paisagem em uma área do Planalto Central Brasileiro. Pesquisa Agropecuária Brasileira. Brasília, v.37, n.6, p.869 - 878, 2002.

MUllA, D. J.; MCBRATNEY, A. B. Soil spatial variability.In: SUMMER, M. E. Handbook of Soil Science. New York: CRC Press, 1999. p. A321-A351.

NETO, M. B. O.; CUNHA, T. J. F.; AlVAREZ, I. A.; SANTOS, J. C. P.; SILVA, M. S. L.; LUCENA, A. M. A.; OLIVEIRA, W. S. Relação solo, paisagem e geologia numa área do Vale do Submédio do Rio São Francisco. IN: Reunião Brasileira de Manejo e Conservação do Solo e da Água. Teresina, 18, 2010. Anais...Teresina, 2010.

NEUMANn, M. R. B. Mapeamento Digital de Solos, no Distrito Federal. 2012, 110p. Tese (Doutorado). Instituto de Geociências, Universidade de Brasília, Brasília. 2012.

NOLASCO-CARVALHO, C. C.; FRANCA-ROCHA, W.; UCHA, J. M. Mapa digital de solos: uma proposta metodológica usando inferência fuzzy. Revista Brasileira de Engenharia Agrícola e Ambiental [online]. 2009, vol.13, n.1ISSN1415-4366.

NOLASCO-CARVALHO, C. C.; NUNES, F. C.; ANTUNES, M. A. H. Histórico do levantamento de solos no Brasil: da industrialização brasileira à era da informação. Revista Brasileira de Cartografia, Rio de Janeiro, n.65/5, p.9971013, 2013.

NOVAES PINTO, M. Caracterização Geomorfológica do Distrito Federal. In: NOVAES, M.P. (Org.) - Cerrado - Caracterização, Ocupação e Perspectivas. Brasília, EditoraUniversidade de Brasília, 1994, p. 285-320.

ODEH, I.O.A.; McBRATNEY, A.B.; CHITTLEBOROUGH, D.J. Further results on prediction of soil properties from terrain attributes: heterotopic cokriging and regression-kriging. Geoderma, v.67, 215-226, 1995.

ONODA, M. Estudo sobre um algoritmo de árvores de decisão acoplado a um sistema de banco de dados relacional. 2001. 110p. Dissertação (Mestrado). Universidade Federal do Rio de Janeiro, Rio de Janeiro. 2001.

OKA-FIORI, C.; FIORI, A. P.; HASSUY, I. Dinâmica da ocupação do solo na bacia do Rio Itiquira, Mato Grosso, Brasil. Revista RA'E GA, Curitiba, n.7, p.19-31, 2003. 
PARK, S. J.; BURT, T. P. Identification and characterization of pedogeomorphological processes on a hillslope. Soil Science Society of American Journal, Stanford, v.66, n.6, p. 1897-1910, 2002.

PENTEADO, O. M. M. Tipos de concreção ferruginosa nos compartimentos geomorfológicos do Planalto de Brasília. Not. Geom., v.16, p.39-53,1976.

RANZANI, G. Manual de levantamentos de solos, 2 ed., Editora Edgard Bücher, 1969.

REATTO, A.; CORREIA, MARTINS, E. S.; FARIAS, M. F. R.; SILVA, A. V.; SPERA, S. T. Levantamento de Reconhecimento de Alta Intensidade dos solo da APA de Cafuringa - DF, escala 1:100.000. Planaltina, DF: Embrapa Cerrados, 2002. 44 p. - Boletim de pesquisa e desenvolvimento/Embrapa Cerrados, ISSN 1679-918, n. 47.

ROCHA, C.H.B. Geoprocessamento: tecnologia transdisciplinar. Juiz de Fora, MG: Ed. do autor, 2000. 220p.

RODRIGUES, M. G. F.; NACIF, P. G. S.; COSTA, O. V.; OLSZEVSKI, N. Solos e suas relações com as paisagens naturais no município de Cruz das Almas, BA. Revista de Biologia e Ciências da Terra, v.9, n.2, p.193-205, 2009.

RODRIGUES, J. B. T.; ZIMBACK, C. R. L.; PIROLI, E. L. Utilização de Sistema de Informação Geográfica na avaliação do uso da terra em Botucatu (SP). Revista Brasileira de Ciência Solo, v 25, p.675-681, 2001.

ROSS, J. L. S. Geomorfologia: Ambiente e planejamento. $8^{a}$ ed., $3^{a}$ reimpressão. São Paulo: Contexto, 2010. 85p. (Repensando a Geografia).

SARMENTO, E. C. Comparação entre quatro algoritmos de aprendizagem de máquina no mapeamento digital de solos no Vale dos Vinhedos. 2010. 109p. Dissertação (Mestrado). Universidade Federal do Rio Grande do Sul, Rio Grande do Sul. 2010.

SCHOORL, J. M.; SONNEVELD, M. P. W.; VEDKAMP, A. Three dimensional landscape process modeling: The effect of DEM resolution. Earth Surface Processes Landforms, v.25, p.1025-1034, 2000.

SILVA, C. C.; COELHO, R. M.; OLIVEIRA, S. R. M.; ADAMI, S. F. Mapeamento pedológico digital da Folha Botucatu (SF-22-Z-B-VI-3): Treinamento de dados em mapa tradicional e validação de campo. Revista Brasileira de Ciência do Solo, v.37, p.846-857, 2013. 
SILVA, M. T. G.; LACERDA, M. P. C.; CHAVES, A. A. A. Geotecnologia aplicada na avaliação do uso das terras da microbacia do Ribeirão João Leite, Goiás. Pesquisa Agropecuária Tropical, Goiânia, v.39, n 4, p.330-337, 2009.

SILVA, S. A.; LIMA, J. S. S. Lógica fuzzy no mapeamento de variáveis indicadoras de fertilidade do solo. Idesia, Chile, v.27, n.3, 2009.

SOIL SURVEY DIVISION STAFF (Washington, D.C.) Soil survey manual. Washington, D.C.: USDA, 1993. 437p. (USDA. Agriculture Handbook, 18).

SOUSA JUNIOR, J. G. A.; DEMATTÊ, J. A. M. Modelo Digital de Elevação na caracterização de solos desenvolvidos e basalto e material arenítico. Revista Brasileira de Ciência do Solo, n.32, p. 449-456, 2008.

SOUZA, R. Q.; LACERDA, M. P. C.; NEUMANN, M. R. B., BORGES, T. D.; MICAS, G. Q.; DUARTE, J. L. P. Aplicação de geotecnologias no estabelecimento das relações entre solos, geologia e geomorfologia na Área de Proteção Ambiental de Cafuringa a fim de gerar um modelo de distribuição de solos nessa APA do Distrito Federal. In: Simpósio Brasileiro de Sensoriamento Remoto, Foz do Iguaçu, 16, 2013, Anais... Foz do Iguaçu, INPE, 2013.

TEN CATEN, A.; DALMOLIN, R. S. D.; MENDONÇA-SANTOS, M. L.; GIASSON, E. Mapeamento Digital de Classes de Solos: características da abordagem brasileira. Ciência Rural, v.42, n.11, 2012.

TEN CATEN, A.; DALMOLIN, R. S. D.; PEDRON, F. A.; MENDONÇA-SANTOS, M. L. Regressões logísticas múltiplas: fatores que influenciam sua aplicação na predição de classes de solos. Revista Brasileira de Ciência do Solo, v.35, n.1, p.53-62, 2011.

TEN CATEN, A.; DALMOLIN, R. S. D.; RUIZ, L. F. C.; SEBEM, E.; PEREIRA, R. S. Mapeamento digital de solos através da aplicação de componentes principais em modelos logísticos. In: Simpósio Brasileiro de Sensoriamento Remoto, Natal, 14, 2009. Anais... Natal, INPE, 2009. p.7677-7684.

TERAMOTO, E.R.; LEPSCH, I.F.; VIDAL-TORRADO, P. Relações solo, superfície geomórfica e substrato geológico na microbacia do ribeirão Marins (PiracicabaSP). Scientia Agricola, v.58, p.361-371, 2001.

VALLADARES, G. S. Geoestatística no mapeamento digital de solos dos tabuleiros costeiros no litoral norte do Estado do Ceará. Revista Equador, v. 1, n. 1, p. 2643, 2012. 
VALLADARES, G. S. PEREIRA, M. G. Proposta de classificação e mapeamento dos solos do Brasil com base na temperatura do ar, usando interpolação e modelo digital de elevação (SRTM). Revista de Geografia, Recife, v. 27, n. 2, 2010.

VIVIANI, E.; MANZATO, G. G. Geração de modelos digitais de superfície por meio de plataformas computacionais com estrutura vetorial e raster. Science \& Engineering Journal, v.15, n. 2, p.27-34, 2005.

WALTER, C.; McBRATNEY, A.B.; DOUAOUI, A.; MINASNY, B. Spatial prediction of topsoil salinity in the ChelifValley,Algeria, using local ordinary kriging with localvariograms versus whole-area variogram. Australian Journal of Soil Research, v.39, 259-272, 2001.

WEBSTER, R. Quantitative spatial analysis of soil in the field. Advances in Soil Science, New York, v.3, p.1-70, 1984.

WEBSTER, R.; BURROUGH, P.A. Computer-based soil mapping of small areas from sample data. 1. Multivariate classification and ordination. Journal of Soil Science, v.23, p.210-221, 1972.

WEIBEL, R.; HELLER, M. "Digital Terrain Modelling”.In: LONGLEY, P. A.; GOODCHILD, M. F.; MAGUIRE, D. J.; RHIND, D. W. (eds.). Geographic Information Systems and Science. 2 ed. v.1, cap.19, p.269-297, 1999.

YOUNG, F. J.; HAMMER, R. D. Defining geographic soil bodies by landscape position, soil taxonomy, and cluster analysis. Soil Science Society of American Journal, Stanford, v.64, n.3, p.989-998, 2000.

ZADEH, L. A. Fuzzy sets. Information and Control, New York, n.8, p.338-353. 1965.

ZEE, Zoneamento Ecológico Econômico do Distrito Federal. Greentec Consultoria e Planejamento Ltda, 2011.

ZELL, A.; MAMIER, G.; VOGT, M.; MACHE, N.; HÜBNER, R.;DÖRING, S.; HERRMANN, K.; SOYEZ, T.; SCHMALZL,M.; SOMMER, T.; HATZIGEORGIOU, A.; POSSELT, D.;SCHREINER, T.; KETT, B.; CLEMENTE, G.; WIELAND, J.; GATTER, J. Stuttgart neural network simulator v.4.2. Stuttgart, University of Stuttgart, Institute forParallel and Distributed High Performance Systems/University of Tübingen - WilhelmSchickard-Institute forComputer Science - Department of ComputerArchitecture, 1996. 338p. 
ZHU, A. X. Mapping soil landscape as spatial continua: the neural network approach. Water Resources Research. v.36, p.663-677, 2000. 


\title{
SOLOS COM HORIZONTE B TEXTURAL E B NÍTICO EM UMA ÁREA PILOTO DO PLANALTO CENTRAL DO BRASIL ${ }^{1}$
}

\section{Rosana Quirino de $\operatorname{Souza}^{2} \&$ Marilusa Pinto Coelho Lacerda ${ }^{3}$}

\author{
${ }^{1}$ Projeto desenvolvido com apoio financeiro da CAPES e FINATEC
}

${ }^{2}$ Aluna do Programa de Mestrado e Doutorado em Agronomia, Área de concentração em Produção Sustentável e linhas de pesquisa em Solo, água e qualidade ambiental, da Faculdade de Agronomia e Medicina Veterinária, da Universidade de Brasília, Campus Universitário Darcy Ribeiro, Instituto Central de Ciências Ala Sul, Caixa Postal 4.508, CEP: 70.910-970, Brasília, DF, rosanakirino@gmail.com

${ }^{3}$ Professora Associado III da Faculdade de Agronomia e Medicina Veterinária da Universidade de Brasília.

\section{RESUMO}

O conhecimento sobre o comportamento e distribuição dos solos que apresentam horizonte B textural e B nítico na região do Planalto Central do Brasil ainda é escasso, fundamentado principalmente em levantamentos de solos generalizados. Entretanto, é possível sanar essa carência por meio de estudos detalhados que possam proporcionar o entendimento das relações entre material de origem, superfícies geomórficas e gênese dos solos formados. O objetivo do presente estudo foi caracterizar e classificar os solos com horizonte B textural e B nítico em geo-topossequências representativas da microbacia do Ribeirão Salinas, DF, a fim de compreender a pedogênese e filiação pedogenética destes solos no Planalto Central do Brasil. Foram selecionados perfis de solos em três geo-topossequências representativas, localizadas na Terceira Superfície Geomorfológica do DF, desenvolvidas a partir de litologias do Grupo Paranoá e preferencialmente do Grupo Canastra. A caracterização dos solos se deu por meio de análises morfológicas, físicas, químicas, mineralógicas e geoquímicas. Para determinação da composição mineralógica utilizou-se a difratometria de Raios-X e para determinação geoquímica foi utilizada a análise de Fluorescência de Raios-X. Os solos das três geo-topossequências apresentaram características morfológicas semelhantes, diferindo principalmente nas características químicas e físicas. Os índices $\mathrm{Ki}$ e $\mathrm{Kr}$ indicaram uma evolução pedogenética pouco acentuada. A mineralogia têm 
predominância dos argilominerais ilita e caulinita, e quanto à geoquímica, os óxidos constituintes mais expressivos nos perfis avaliados foram $\mathrm{K}_{2} \mathrm{O}$ e $\mathrm{TiO}_{2}$. Os solos estudados foram classificados no $4^{\circ}$ nível categórico do Sistema Brasileiro de Classificação de Solos.

Palavras-chave: gênese dos solos, mineralogia, geoquímica, estudo de geotopossequências.

\begin{abstract}
The knowledge of the behavior and distribution of soils with argillic horizons in the Plateau Brazilian Central region is still scarce, mainly based on generalized soil surveys. However, you can remedy this deficiency by means of detailed studies that can provide the understanding of the relationships between source material, geomorphic surfaces and genesis of soils formed. The aim of this study was to characterize and classify the soil with argillic horizons in representative geo-toposequences of the Ribeirão Salinas, Distrito Federal (DF), in order to understand the pedogenesis and filiation pedogenetic of these soils in the Central Brazilian Plateau. Soil profiles were selected in three representative geo-toposequences, located in the DF Third geomorphological area, developed from lithologies of Paranoá and preferably Canastra Group. Soil characterization was made by morphological, physical, chemical, mineralogical and geochemical analysis. Was determined the mineralogical composition through X-ray diffractometry and fluorescence X-ray analysis was used to determine the soils geochemistry composition. . The morphological characteristics of soils geotopossequences were similar, differing primarily on the chemical and physical characteristics. $\mathrm{Ki}$ and $\mathrm{Kr}$ indices indicated a low degree pedogenetic evolution of soils studied. The mineralogy have predominance of illite and kaolinite clay minerals, and the geochemistry, the most significant constituent oxides were $\mathrm{K}_{2} \mathrm{O}$ and $\mathrm{TiO}_{2}$. The soils were classified in the 4th category level of the Brazilian System of Soil Classification.
\end{abstract}

Key-words: soil genesis, mineralogy, geochemical, study of geo-toposequences. 


\section{1 - INTRODUÇÃO}

Apesar dos solos do Planalto Central Brasileiro serem lembrados freqüentemente como profundos, pobres em nutrientes, praticamente sem minerais primários facilmente intemperizáveis e localizados em áreas planas a suave onduladas, caracterizadas por relevo de chapadas, é importante ressaltar que ocorrem, também, solos rasos, principalmente Cambissolos e Neossolos Litólicos, situados em áreas acidentadas e que, embora comumente álicos, podem ser até eutróficos, dependo da rocha de origem (Resende et al., 1988). Nas áreas de relevo mais movimentado podem ser também encontrados outros solos eutróficos, tais como Argissolos e Nitossolos, geralmente relacionados com materiais de origem mais enriquecidos em elementos nutrientes (Ker e Resende, 1996).

No Planalto Central do Brasil, especificamente na porção noroeste do Distrito Federal (DF), na microbacia do Ribeirão Salinas, são encontradas formações geológicas de idade Meso/Neoproteozóica (1.300 a 1.100 milhões de anos) representadas pelos Grupos Paranoá e Canastra. Segundo Martins et al. (2004) o Grupo Paranoá é composto por rochas metapsamo-pelíticas e carbonatadas. O Grupo Canastra, por sua vez, no DF, é constituído principalmente por clorita e sericita filitos e subordinadamente calcifilitos, filitos carbonosos, quartzitos e mármores finos.

Essas formações geológicas encontram-se inseridas na superfície geomorfológica mais recente do Distrito Federal - denominada de Terceira Superfície (Motta et al., 2002), caracterizada por uma topografia mais acidentada, com predominância de relevos ondulados, forte ondulados a montanhosos, correspondendo às áreas de dissecação mais recente no DF.

Segundo o Levantamento de Reconhecimento de Solos realizado pela Embrapa (1978) nessa Superfície ocorrem os solos de maior fertilidade natural do DF, que são os solos com horizonte B textural e B nítico, tais como Nitossolos Vermelhos, Argissolos e Chernossolos. Estes solos desenvolvem-se no Vale do Rio Maranhão, a partir de litologias do Grupo Canastra e rochas carbonatadas do Grupo Paranoá. Nesta região, observam-se áreas de desenvolvimento de vegetação de porte florestal.

Diante desse cenário, o estudo mais aprofundado da pedogênese, caracterização e classificação detalhada destes solos no Planalto Central Brasileiro, particularmente no Distrito Federal, têm papel fundamental no entendimento do seu comportamento e distribuição na paisagem de ocorrência no DF, por meio de estabelecimento de relações 
entre classes de solo, relevo e material de origem (relações pedomorfogeológicas) uma vez que esses solos são distintos das demais classes de solos que caracterizam esta região do Brasil (Souza et al., 2013).

Motta et al. (2002) identificaram as principais relações solos-superfícies geomórficas presentes em uma área representativa do Planalto Central Brasileiro e verificaram, entre outros fatores, que nas áreas de dissecação mais recente, de relevo bastante movimentado, que varia de suave ondulado a montanhoso, a relação entre os solos e o substrato rochoso é estreita e há formação de solos rasos, principalmente Cambissolos Háplicos (CX) e, em menores proporções, Argissolos Vermelhos (PE), Argissolos Vermelho-Amarelos (PVA) e Nitossolos Vermelhos Eutroférricos (NVef). Nas áreas ocupadas por essas classes de solos a vegetação é sempre florestal, relacionada à maior fertilidade natural desses solos.

Estudos envolvendo relações solos-paisagem e solos-material de origem têm auxiliado a compreensão da distribuição de classes diversificadas de solos numa dada região, podendo-se citar Nunes et al. (2001), Lacerda et al. (2008), Barbosa et al., (2009), entre tantos outros.

Assim, o objetivo do presente estudo foi a caracterização dos solos com horizonte B textural e B nítico na microbacia do Ribeirão Salinas, DF, representativa da ocorrência destes solos no Planalto Central do Brasil. O trabalho visou, ainda, avaliar a filiação pedogenética destes solos nesta Região do Brasil.

\section{2 - MATERIAL E MÉTODOS}

Inicialmente foi realizado o levantamento de dados e revisão bibliográfica das características do meio físico da região da microbacia do Ribeirão Salinas tais como solos (Embrapa, 1978), geologia (Freitas-Silva e Campos, 1998), geomorfologia (Motta et al., 2002) na escala 1:100.000, mineralogia dos solos (Kämpf et al., 1998), pedogênese, filiação genética dos solos (Lacerda et al., 2002), entre outros.

Mediante a avaliação dessas informações foi realizado o estudo entre as formações geológicas, a variação geomorfológica e as classes de solos formadas, visando o estabelecimento preliminar das relações pedomorfogeológicas da área de estudo. As classes de solos compreendidas neste estudo foram as que apresentam preferencialmente horizonte B textural e B nítico, visto que nessas classes de solos a herança do material parental é mais preservada e mais facilmente detectável, em função 
do grau de evolução destes solos, em relação às demais classes de solos encontradas na região da microbacia estudada tais como Latossolos, Cambissolos e Neossolos.

A figura 4 apresenta um fluxograma resumido da metodologia utilizada neste estudo.

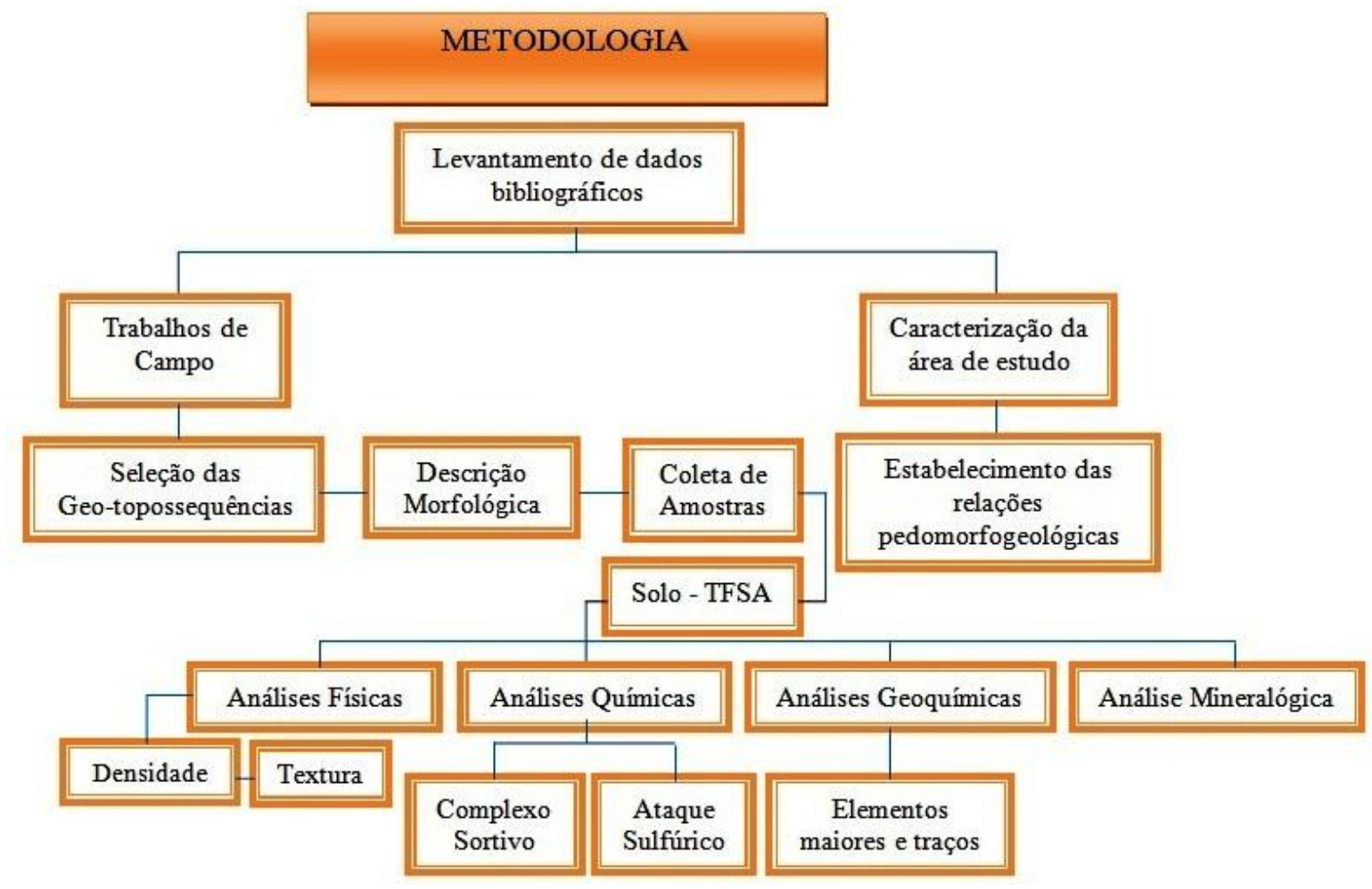

Figura 4. Fluxograma resumido da metodologia utilizada no estudo.

\subsection{1 - Localização da área de estudo}

A área de estudo localiza-se na porção noroeste do Distrito Federal - DF, entre as coordenadas geográficas $15^{\circ} 30^{\prime}$ e $15^{\circ} 35^{\prime}$ de latitude sul e $47^{\circ} 54^{\prime}$ e $47^{\circ} 58^{\prime}$ longitude oeste (datum horizontal SIRGAS 2000). Tal microbacia encontra-se inserida na Área de Proteção Ambiental de Cafuringa, que possui 46.000 ha e limita-se ao sul com as rodovias DF 001 e DF 220, ao norte e oeste pela divisa do Distrito Federal com Goiás, e a leste com a rodovia DF 150 e o Ribeirão da Contagem (Figura 5). 


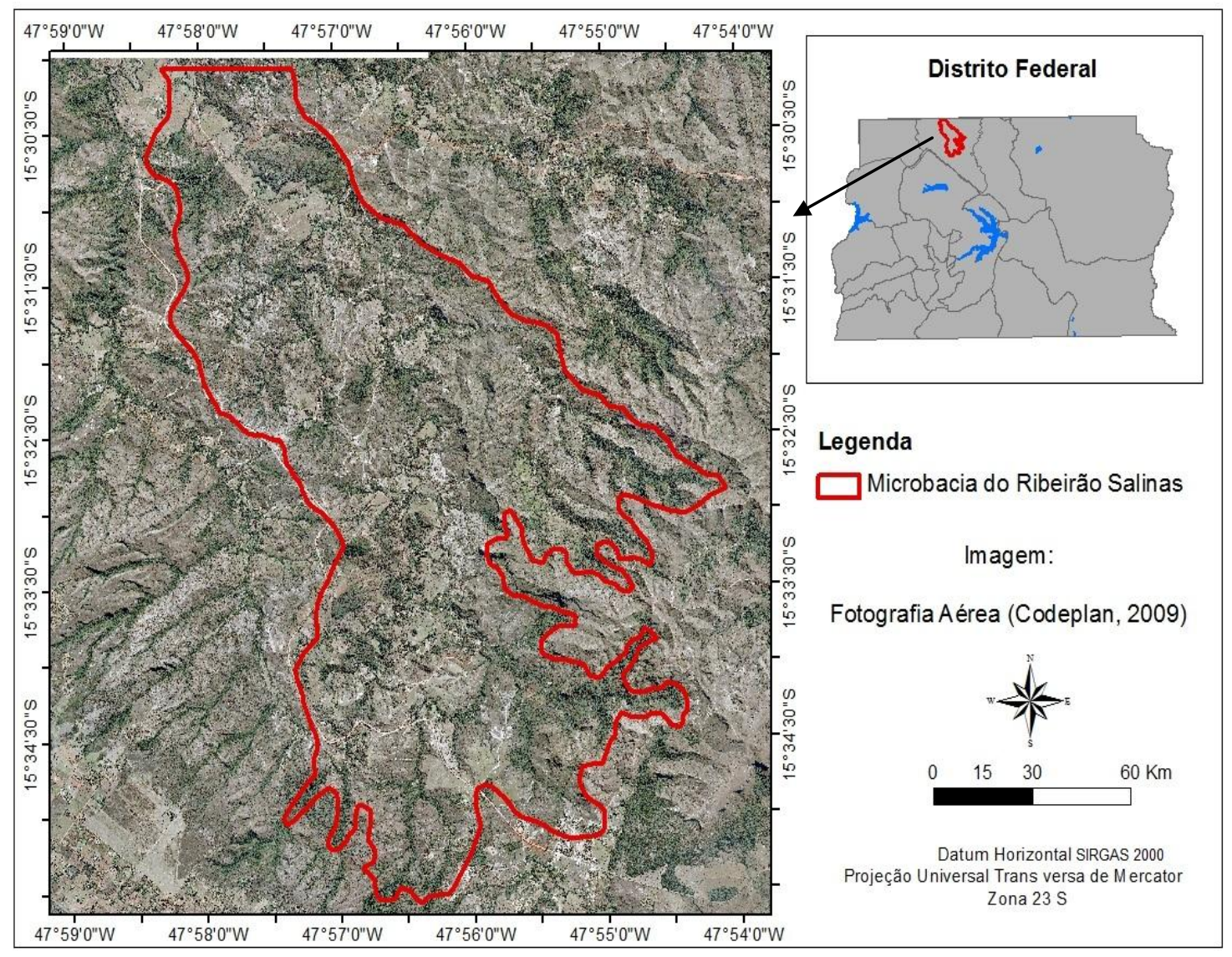

Figura 5. Localização da microbacia do Ribeirão Salinas, DF. Fotografia Aérea (Codeplan, 2009).

\subsection{2 - Caracterização do meio físico da microbacia do Ribeirão Salinas.}

Na microbacia do Ribeirão Salinas são reconhecidos dois conjuntos litológicos, incluindo parte dos Grupos Paranoá e Canastra. O Grupo Paranoá corresponde a uma sequência psamo-pelito-carbonatada enquanto o Grupo Canastra é representado por um conjunto de sericita filitos, clorita filitos, quartzo-sericita-clorita filitos, metarritmitos e filitos carbonosos (Freitas-Silva e Campos, 1998; ZEE, 2011).

A geomorfologia da área de estudo é caracterizada por um relevo ondulado a forte ondulado, com elevada densidade de drenagens, declividades superiores a $20 \%$ e cotas inferiores a $800 \mathrm{~m}$. Essa Superfície Geomorfológica do Distrito Federal foi descrita por diversos autores e cada um deles propôs uma denominação para esse compartimento da paisagem: Terceira Superfície (Penteado, 1976; Motta et al., 2002), Depressões Interplanálticas e Planalto Dissecado do Alto Maranhão (Codeplan, 1984), Região Dissecada de Vale (Novaes Pinto, 1994), Planícies (Martins e Baptista, 1998), Vale Dissecado (ZEE, 2011). 
O clima da região é do tipo Aw, tropical, com temperatura do mês mais frio superior a $18^{\circ} \mathrm{C}$ em média e com estações chuvosa e seca (SEMARH, 2006).

As fitofisionomias encontradas na área de estudo são representadas por Formações Florestais (Floresta Tropical Subcaducifólia, Mata de Galeria, Mata Seca, Cerradão), Formações Savânicas (Cerrado Sentido Restrito, Cerrado Típico, Cerrado Ralo), Formações Campestres (Campo Limpo, Campo Sujo) e Vereda (Reatto et al., 2002a).

Os solos encontrados na microbacia do Ribeirão Salinas são representados pelas classes dos Latossolos, Cambissolos, Neossolos, Argissolos, Nitossolos e Chernossolos (Embrapa, 1978). As características desses solos segundo Embrapa (1978) e ZEE (2011), são descritas a seguir:

\section{Latossolos}

Esses são solos submetidos a consideráveis processos de lixiviação de bases ao longo do seu perfil, resultando em um perfil pedológico no qual o material encontra-se altamente intemperizado, com alteração intensa dos silicatos e concentrações de óxidos e hidróxidos de ferro e alumínio. No perfil de um Latossolo, a transição entre os horizontes é gradual ou difusa e a textura exibe-se de maneira uniforme, não havendo acúmulo de argila. Nessa classe, os solos apresentam elevada acidez. Quando a vegetação associada apresenta maior densidade foliar o Latossolo exibe-se menos distrófico ou com maior saturação de bases.

O horizonte B diagnóstico, latossólico, constitui-se com uma espessura mínima de $50 \mathrm{~cm}$ que apresenta, em geral, textura franco arenosa a argilosa, baixa capacidade de troca de bases, grande estabilidade dos agregados, microestrutura ou blocos subangulares fracos a moderados e poucos minerais resistentes ao intemperismo. Essa classe é representada pelas seguintes subordens: Latossolo Vermelho e Latossolo Vermelho-Amarelo.

\section{Cambissolos}

Essa é uma classe formada por solos pouco desenvolvidos, cuja pedogênese já alterou o material de origem, mas ainda encontram-se fragmentos de minerais primários e materiais pedregosos e rochosos. Esses solos ocorrem principalmente nas vertentes e 
encostas com pendentes mais elevadas, sendo abundantes na unidade de Rebordo, em relevos que variam entre os compartimentos Escarpados e Planos Intermediários com altitudes entre 800 e 1.150 metros, além do compartimento de Vales Dissecados (Novaes Pinto, 1994; Martins e Baptista, 1998).

Também é comum a existência de grandes quantidades de cascalho e uma vegetação caracteristicamente associada de campo limpo. O alto teor de silte do horizonte A e a restrita profundidade do perfil fazem com que essa classe de solos tenha sua permeabilidade dificultada. A junção dessas características com as taxas elevadas de declividade nos locais onde esses solos ocorrem significam um sério empecilho à mecanização e os tornam mais susceptíveis à erosão. A migração de argila ao longo do perfil é inibida e o horizonte A passa a permanecer com os seus mais elevados teores. Já o horizonte B incipiente, apresenta-se com muitos fragmentos do material de origem, constituindo-se, em geral, de metarritmito e quartzito caracterizando-se comumente em distróficos e muito ácidos.

\section{Neossolos}

Esses solos são discriminados por possuir um perfil pouco desenvolvido pedogeneticamente. Assim, quando o horizonte B ocorre, não coincide com nenhum diagnóstico, predominando as características do material de origem.

Os Neossolos são classificados em Quartzarênicos, Flúvicos, Litólicos e Regolíticos.

\section{Solos com horizonte B textural e B nítico}

Na porção norte do Distrito Federal, no vale do rio Maranhão, ocorrem solos com gradiente textural onde parte da argila total presente no horizonte A migra por translocação vertical para o horizonte B. Nesse contexto ocorrem manchas de Nitossolos, Argissolos e Chernossolos.

Nitossolo Vermelho: são profundos e bem desenvolvidos. Apresentam horizonte B nítico e argila de baixa atividade. São, em geral, moderadamente ácidos, com saturação por bases variável, podendo inclusive ser eutróficos. 
Argissolo Vermelho: são de profundidade variável, apresentam horizonte B textural e argila de atividade baixa. São geralmente ácidos com saturação por bases alta e por isso são recobertos por fases florestais com elevada densidade de espécies arbóreas de elevado porte.

Chernossolo: são solos com alta saturação por bases, argila de atividade alta e horizonte A chernozêmico, no caso do Distrito Federal, preferencialmente com horizonte B textural.

\subsection{3 - Seleção e caracterização dos solos em geo-topossequências}

O método de avaliação pedológica adotado foram as geo-topossequências representativas da área de estudo, que foram selecionadas em trabalhos de campo. A seleção destas e dos perfis para o estudo foi realizada por meio das relações préestabelecidas entre o substrato geológico, a variação do relevo, e as classes de solos formadas (relações pedomorfogeológicas).

As classes de solos avaliadas neste estudo foram as que apresentam, preferencialmente, horizonte B textural e B nítico, visto que nessas classes de solos a herança do material parental é mais preservada e pode ser facilmente detectável, em função do grau de evolução destes, em relação às demais classes de solos encontradas na região da microbacia do Ribeirão Salinas, tais como Latossolos, Cambissolos e Neossolos. Foram selecionadas três geo-topossequências (Figura 6).

A primeira foi denominada de Geo-topossequência Catingueiro, localizada na porção central da microbacia estudada. A segunda - Geo-topossequência Pedreira, disposta na parte norte da área de estudo. A terceira nomeada de Geo-topossequência DF-205, localizada na porção sudoeste da microbacia, às margens da rodovia estadual DF -205 . 


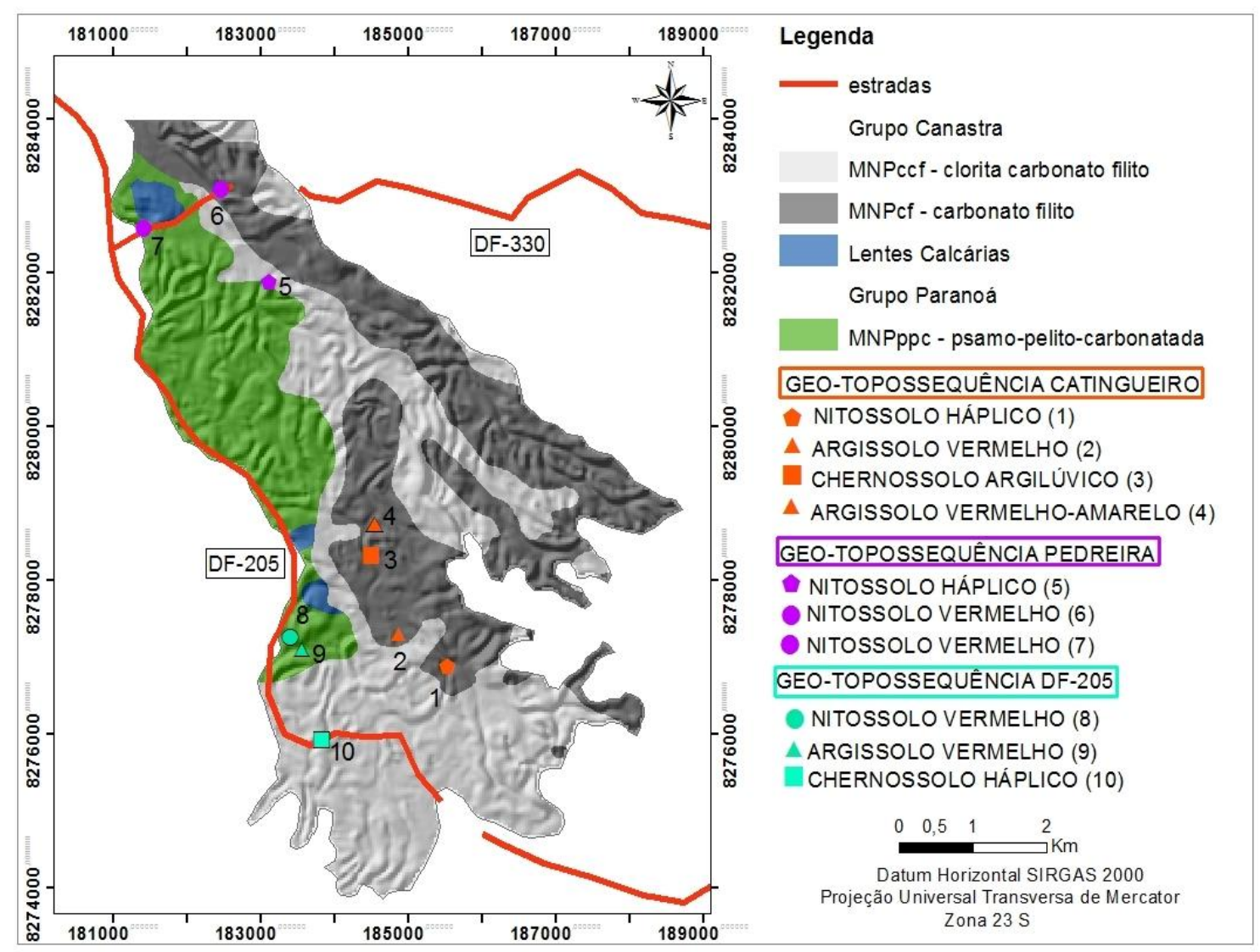

Figura 6. Localização das geo-topossequências da microbacia do Ribeirão Salinas, DF.

Ao longo das três geo-topossequências foram selecionados 10 perfis representativos dos solos com horizonte B textural e B nítico para caracterização, descrição morfológica e classificação no Sistema Brasileiro de Classificação de Solos (Embrapa, 2013).

As análises morfológicas foram realizadas em cortes de estrada em todos os horizontes dos perfis representativos das geo-topossequências de acordo com Santos et al. (2005). As análises laboratoriais (físicas e químicas) foram realizadas nos horizontes A e B diagnóstico, onde se utilizou amostras de solo na fração TFSA (Terra Fina Seca ao Ar), peneiradas em malha $2 \mathrm{~mm}$. As análises mineralógicas e geoquímicas foram realizadas no horizonte B diagnóstico. 


\subsection{4 - Análises Morfológicas}

A descrição morfológica dos perfis pedológicos representativos foi baseada em Santos et al. (2005). Os principais atributos avaliados foram: cor úmida, espessura dos horizontes, textura, estrutura, cerosidade, consistência e transição entre horizontes.

\subsection{5 - Análises Físicas}

\subsubsection{1 - Densidade do Solo}

A densidade do solo foi determinada segundo o método do anel volumétrico (Embrapa, 1997), o qual consiste na coleta de amostras de solos indeformadas por meio de um anel de aço (Kopecky) de bordas cortantes e volume interno conhecido.

\subsubsection{2 - Textura}

Na determinação da textura do solo foi utilizado o Método do Densímetro, conhecido também como método do hidrômetro (Embrapa, 1997). O método consiste na determinação da proporção das frações argila, silte e areia baseado no tempo de sedimentação dessas partículas.

\subsection{6 - Análises Químicas}

\subsubsection{Complexo Sortivo}

As análises químicas do complexo sortivo realizadas foram: $\mathrm{pH}$ em água, que consiste na imersão de eletrodos na suspensão solo-líquido e medição da atividade de íons $\mathrm{H}^{+}$; acidez potencial $\mathrm{H}+\mathrm{Al}$, determinado em acetato de cálcio; matéria orgânica, método Walkley-Black, baseado na oxidação da matéria orgânica do solo a $\mathrm{CO}_{2}$ e $\mathrm{H}_{2} \mathrm{O}$ por íons dicromato em meio fortemente ácido; $\mathrm{Ca}^{2^{+}}+\mathrm{Mg}^{2^{+}}$e $\mathrm{Al}^{3^{+}}$extraídos por $\mathrm{KCl}, \mathrm{K}^{+}$ determinado por espectrofotometria de chama e o $\mathrm{P}_{2} \mathrm{O}_{5}$ por solução extratora de Melich, todas análises realizadas segundo Embrapa (1997). 


\subsubsection{Ataque Sulfúrico}

Os elementos determinados pelo ataque por $\mathrm{H}_{2} \mathrm{SO}_{4}$ foram o ferro e o alumínio, determinados complexometricamente por titulação e expressos na forma de $\mathrm{Fe}_{2} \mathrm{O}_{3} \mathrm{e}$ $\mathrm{Al}_{2} \mathrm{O}_{3}$ e a sílica, extraída por solução $\mathrm{NaOH}_{2} \mathrm{O}$ e determinada por gravimetria (Embrapa, 1997).

\subsection{7 - Análises Mineralógicas}

As análises mineralógicas foram realizadas com a fração argila extraída da TFSA em amostras representativas do horizonte diagnóstico de cada perfil avaliado, por meio de difratometria de Raios-X. Primeiramente realizou-se o mesmo procedimento para determinar a textura do solo (método de Boyoucos) onde a fração areia foi previamente separada das frações silte e argila por tamizamento em peneiras de malha de 0,05 mm. A fração argila foi separada, por suspensão aquosa, em volume correspondente a $10 \mathrm{~cm}$ em provetas de $1 \ell$, de $8 \mathrm{em} 8$ horas após agitação e sedimentação, por quatro dias, baseado na Lei de Stokes. Com a fração argila separada foram preparadas lâminas orientadas do horizonte B de cada perfil pela técnica do "esfregaço". Após secagem ao ar as lâminas foram analisadas segundo três tratamentos: normal, aquecida e glicolada (Hughes et al., 1994).

$\mathrm{O}$ tratamento designado de normal foi realizado em temperatura ambiente. No tratamento por aquecimento as lâminas foram aquecidas a $490^{\circ} \mathrm{C}$, em mufla por 3:30 hs. Para o tratamento de glicolagem as amostras foram tratadas com glicerol, composto orgânico que é utilizado como um auxiliar para o tratamento de expansão dos argilominerais 2:1 (Melo e Wypych, 2009).

Segundo Besoain (1985) em regra, as análises por DRX incluem tratamentos de aquecimento e/ou glicolagem das lâminas da fração argila para confirmar a presença de algum argilomineral importante ou de difícil identificação. Alguns minerais, dependendo da temperatura de aquecimento, perdem suas estruturas características, tal como ocorre com a gibbsita e a caulinita, quando aquecidas a $490^{\circ} \mathrm{C}$; enquanto o tratamento de glicolagem demonstra a presença e identifica os argilominerais expansivos, quando existentes.

Posteriormente as lâminas foram submetidas para leituras no difratômetro. O difratômetro utilizado foi o RIGAKU, modelo "Geiger Fix" D-Max-B, do Laboratório 
de Difratometria de Raios-X do Instituto de Geociências (IG) da Universidade de Brasília. O difratômetro foi operado com tubo de cobre, sob voltagem de $35 \mathrm{Kv}$ e 15 $\mathrm{mA}$, com velocidade de varredura de $1^{\circ}$ /minuto no intervalo de $2 \theta$ de 2 a $40^{\circ}$.

\subsection{8 - Análise Geoquímica}

Para caracterização da composição geoquímica dos solos avaliados, procederamse análises geoquímicas na fração TFSA dos horizontes diagnósticos dos solos avaliados, onde foi utilizado o método de Fluorescência de Raios-X, com a finalidade de identificar os elementos maiores ou óxidos constituintes $\left(\mathrm{Al}_{2} \mathrm{O}_{3}, \mathrm{SiO}_{2}, \mathrm{Fe}_{2} \mathrm{O}_{3}, \mathrm{~K}_{2} \mathrm{O}\right.$, $\mathrm{CaO}, \mathrm{MgO}, \mathrm{Na}_{2} \mathrm{O}, \mathrm{TiO}_{2}, \mathrm{MnO}$ e $\mathrm{P}_{2} \mathrm{O}_{5}$ ) e elementos menores ou traços tais como Ti, $\mathrm{V}$, $\mathrm{Cr}, \mathrm{Co}, \mathrm{Ni}, \mathrm{Cu}, \mathrm{Zn}, \mathrm{Rb}, \mathrm{Sr}, \mathrm{Mo}, \mathrm{S}, \mathrm{Pb}$ e Nb. Tais análises objetivaram a obtenção de informações a respeito filiação dos solos estudados, mediante avaliação composição química das rochas que deram origem aos mesmos e o reflexo no comportamento químico destes solos devido à herança de elementos químicos dos seus materiais de origem.

A análise por Fluorescência de Raios-X pode ter fins qualitativos ou quantitativos e se baseia na medição das intensidades dos raios- $\mathrm{X}$ característicos emitidos pelos elementos que constituem a amostra, quando excitada por partículas como elétrons, prótons ou íons produzidos em aceleradores de partículas ou ondas eletromagnéticas, além do processo mais utilizado que é por meio de tubos de raios-X (Melo Júnior, 2007).

A Espectrometria de Fluorescência de Raios X (FRX) é uma das técnicas analíticas mais utilizadas em avaliações geoquímicas. A indústria mineral, tanto de exploração como de beneficiamento também utiliza amplamente a fluorescência de raios-X, especialmente para fins de controle do processamento. As aplicações principais em geoquímica são as determinações de elementos maiores, menores e traços em rochas, solos e sedimentos. Dentre os elementos-traços, os mais favoráveis à determinação por FRX, em função de limites de detecção e abundância crustal, são Ba, $\mathrm{Ce}, \mathrm{Cr}, \mathrm{Cu}, \mathrm{Ga}, \mathrm{La}, \mathrm{Nb}, \mathrm{Ni}, \mathrm{Pb}, \mathrm{Rb}, \mathrm{Sc}, \mathrm{Sr}, \mathrm{Th}, \mathrm{V}, \mathrm{Y}, \mathrm{Zn}, \mathrm{Zr}$. Os resultados da FRX para estes elementos sempre são de concentrações elementares totais. A FRX também pode ser útil na análise de amostras mineralizadas, para determinar elementos em concentração anômala (p.ex., As, Sb, Bi, Ta, W, Cu, Zn, Ni, B,Mo) (Enzweiler, 2010). 
Um dos principais atrativos da FRX é a relativa simplicidade de preparação das amostras já pulverizadas. A fusão das amostras com fundentes e o posterior resfriamento gera produtos amorfos ou vítreos. Esta forma de homogeneização da amostra facilita a determinação de elementos maiores e menores ( $\mathrm{Na}, \mathrm{Mg}, \mathrm{Al}, \mathrm{Si}, \mathrm{P}, \mathrm{K}$, $\mathrm{Ca}, \mathrm{Ti}, \mathrm{Mn}, \mathrm{Fe})$. A preparação direta de pastilhas prensadas a partir das amostras pulverizadas também é muito usada, mas encontra aplicação mais frequente na determinação de elementos-traço. Os limites de detecção da FRX convencional, da ordem de alguns até dezenas de $\mathrm{mgkg}^{-1}$, não são uniformes para todos os elementos. Elementos leves $(Z<10)$ não são analisados na $F R X$ convencional e a baixa concentração de muitos elementos-traço (p.ex., metais nobres) em amostras geológicas comuns impede a sua determinação por esta técnica (Enzweiler, 2010).

O método utilizado no presente estudo foi a Fluorescência de Raios-X por meio da elaboração de pastilhas de pó prensado. Em solos, as análises geoquímicas são úteis em estudos pedogenéticos, particularmente em solos mais jovens, tais como os solos com horizonte B textural ou B nítico, por preservarem elementos dos seus materiais parentais. É também utilizado para a avaliação da ocorrência de elementos nutrientes, presentes tanto nos elementos maiores quanto nos elementos-traço, sendo que estes últimos incluem alguns dos micronutrientes; assim como na detecção dos elementos considerados metais pesados, que podem provocar contaminação dos solos. Neste estudo foram selecionados para análise os elementos maiores e os traços $\mathrm{Ti}, \mathrm{V}, \mathrm{Cr}, \mathrm{Co}$, $\mathrm{Ni}, \mathrm{Cu}, \mathrm{Zn}, \mathrm{Rb}, \mathrm{Sr}, \mathrm{Mo}, \mathrm{S}, \mathrm{Pb}$ e Nb , para avaliação de herança de elementos nutrientes e metais pesados a partir das litologias de origem. A análise dos elementos maiores e traços selecionados permitirão avaliar a presença de macronutrientes: $\mathrm{P}, \mathrm{K}, \mathrm{Ca}, \mathrm{Mg}$ e S e os micronutrientes: $\mathrm{Cu}, \mathrm{Fe}, \mathrm{Mn}$, Mo e $\mathrm{Zn}$. Os demais elementos-traço selecionados para análise apresentam afinidade geoquímica com os elementos nutrientes, podendo ocorrer associadamente, e foram também avaliados alguns elementos considerados metais pesados. 


\section{3 - RESULTADOS E DISCUSSÃO}

\subsection{1 - Atributos Morfológicos}

Os resultados das análises morfológicas dos solos estudados estão apresentados nas tabelas 1, 2 e 3. Como o objetivo do trabalho foi a avaliação dos solos com horizonte $\mathrm{B}$ textural e $\mathrm{B}$ nítico, os perfis pedológicos estudados das três geotopossequências - Geo-topossequência Catingueiro (Figura 7), Geo-topossequência Pedreira (Figura 8) e Geo-topossequência DF-205 (Figura 9) são semelhantes morfologicamente quanto à estrutura em blocos, consistência e cerosidade. Os perfis que apresentaram comportamento discordante em relação as características morfológicas foram o MTf (perfil III da Geo-topossequência Catingueiro) e o MXf (perfil I da Geo-topossequência DF-205), pois diferentemente dos demais perfis avaliados, apresentaram o horizonte B incipiente como horizonte de subsuperfície. No geral, a textura dos solos estudados é argilosa, uma vez que se originam de litologias pelito-carbonatadas do Grupo Paranoá; e sericita filitos, clorita filitos, quartzo-sericitaclorita filitos e filitos carbonosos do Grupo Canastra. Diferem-se principalmente no que diz respeito à cor.

A cor é um dos mais úteis atributos para caracterizar solos e sua determinação constitui importante fonte de informação para pedologia (Campos e Demmatê, 2004). A cor do solo pode variar de acordo com seus constituintes (Schwertmann, 1993), como óxidos de ferro, matéria orgânica, umidade e granulometria (Fernandez e Schulze, 1992).

Nos solos estudados, avaliou-se a variação na coloração dentro das classes de solos. Os Argissolos, representados pelos Argissolos Vermelhos e Argissolos Vermelho-Amarelos, apresentaram cores similares entre os horizontes, variando a matiz de 2,5YR a 5YR. Os Nitossolos, representados na área de estudo pelos Nitossolos Vermelhos e Nitossolos Háplicos, apresentaram coloração variando de vermelho acinzentado (10R) a brunado (7,5YR). Já os Chernossolos apresentaram coloração semelhante aos Nitossolos Vermelhos com horizonte A chernozêmico, com matiz 10R, no horizonte de superfície (Tabelas 1, 2 e 3).

Para Pereira et al. (2012) os Chernossolos apresentam cores mais escuras no horizonte A chernozêmico devido a associação do carbono orgânico com o íon cálcio que leva à formação de humatos de cálcio, o que confere maior estabilidade à matéria 
orgânica. Já as cores mais avermelhadas nos horizontes de subsuperfície são decorrentes de áreas com boas condições de drenagem. A cor vermelha é uma característica comum em solos desenvolvidos a partir de rochas carbonáticas e denotativa da presença de hematita, cuja formação é favorecida em condições de $\mathrm{pH}$ elevado e drenagem desimpedida (Schwertmann e Taylor ,1989).

Motta et al. (2002) estudando as relações solo-superfície geomórfica e evolução da paisagem em uma área do Planalto Central Brasileiro verificaram a ocorrência de Argissolo Vermelho (PE), Argissolo Vermelho-Amarelo (PV) e Nitossolo Vermelho Eutroférrico (NVef), observando que o NVef apresentou cor úmida 2,5YR 3/2 no horizonte B diagnóstico, enquanto o PV mostrou coloração menos avermelhada, 5YR 5/6. Comportamento semelhante foi observado por Reatto et al. (2002b) na região da APA de Cafuringa, DF, onde o Argissolo Vermelho descrito por estes autores apresentou coloração com matiz de 7,5YR 4/6, e o Nitossolo Vermelho apresentou coloração mais avermelhada 5YR 3/4.

De acordo com Embrapa (1978) os Argissolos têm cores vivas da gama vermelho-amarelado, enquanto os Nitossolos apresentam horizonte B nítico com cores, em geral, vermelha, vermelho-escura ou bruno-avermelhada, os Chernossolos por sua vez, tendem a ser pouco coloridos, escuros ou com tonalidades pouco cromadas e de matizes com baixos valores no horizonte A chernozêmico.

Os Argissolos e Nitossolos da área de estudo tiveram sua coloração determinada principalmente pela natureza dos seus materiais de origem, rochas psamo-pelitocarbonatadas do Grupo Paranoá e rochas carbonatadas do Grupo Canastra enquanto os Chernossolos e Nitossolos Vermelhos com horizonte A chernozêmico tiveram sua coloração fortemente influenciada pela matéria orgânica no horizonte superficial e pela concentração de óxidos de ferro no horizonte diagnóstico.

Por meio da descrição morfológica é possível observar que os Nitossolos da área de estudo são bem desenvolvidos, profundos, com transição entre horizontes gradual a difusa e predominantemente ondulada. Os Argissolos em contrapartida são menos profundos, com transição entre horizontes gradual e ondulada. Já os Chernossolos são rasos e com transição semelhante aos Argissolos. 
Tabela 1. Características morfológicas dos perfis da Geo-topossequência Catingueiro.

\begin{tabular}{|c|c|c|c|c|c|}
\hline \multirow[t]{2}{*}{ Horizonte } & \multirow[t]{2}{*}{ Profundidade } & Cor & \multirow[t]{2}{*}{ Textura } & \multirow[t]{2}{*}{ Estrutura } & \multirow[t]{2}{*}{ Consistência } \\
\hline & & Úmida & & & \\
\hline \multicolumn{6}{|c|}{ Perfil I - NITOSSOLO HÁPLICO Distrófico úmbrico - NXd } \\
\hline A & $0-28 \mathrm{~cm}$ & 5YR 4/4 & Argilosa & $\begin{array}{c}\text { forte média } \\
\text { blocos } \\
\text { subangulares } \\
\end{array}$ & $\begin{array}{l}\text { ligeiramente dura, } \\
\text { firme, ligeiramente } \\
\text { plástica e pegajosa }\end{array}$ \\
\hline $\mathrm{AB}$ & $28-59 \mathrm{~cm}$ & $5 \mathrm{YR} 4 / 4$ & Argilosa & $\begin{array}{l}\text { forte média } \\
\text { blocos } \\
\text { subangulares } \\
\end{array}$ & $\begin{array}{c}\text { dura, firme, } \\
\text { ligeiramente plástica } \\
\text { e pegajosa }\end{array}$ \\
\hline Bt (nítico) & $59 \mathrm{~cm}+$ & 5YR 4/6 & Argilosa & $\begin{array}{l}\text { forte média } \\
\text { blocos } \\
\text { subangulares } \\
\end{array}$ & $\begin{array}{c}\text { dura , firme, plástica } \\
\text { e pegajosa }\end{array}$ \\
\hline \multicolumn{6}{|c|}{ Perfil II - ARGISSOLO VERMELHO Eutroférrico típico - PVef } \\
\hline A & $0-36 \mathrm{~cm}$ & 5YR 3/4 & Média & $\begin{array}{c}\text { forte pequena } \\
\text { blocos angulares }\end{array}$ & $\begin{array}{c}\text { dura, firme, plástica } \\
\text { e pegajosa }\end{array}$ \\
\hline $\mathrm{AB}$ & $36-58 \mathrm{~cm}$ & 5YR 3/4 & Média & $\begin{array}{c}\text { forte média } \\
\text { blocos angulares }\end{array}$ & $\begin{array}{l}\text { dura, firme, muito } \\
\text { plástica e muito } \\
\text { pegajosa }\end{array}$ \\
\hline $\mathrm{Bt}$ & $58 \mathrm{~cm}+$ & $2,5 \mathrm{YR} 4 / 8$ & Argilosa & $\begin{array}{c}\text { forte média } \\
\text { blocos angulares }\end{array}$ & $\begin{array}{c}\text { extremamente dura, } \\
\text { extremamente firme, } \\
\text { muito plástica e } \\
\text { muito pegajosa }\end{array}$ \\
\hline \multicolumn{6}{|c|}{ Perfil III - CHERNOSSOLO ARGILÚVICO Férrico típico - MTf } \\
\hline A & $0-60 \mathrm{~cm}$ & 10R 3/4 & Argilosa & $\begin{array}{c}\text { moderada } \\
\text { grande a média } \\
\text { blocos } \\
\text { subangulares }\end{array}$ & $\begin{array}{c}\text { dura, firme, plástica e } \\
\text { pegajosa }\end{array}$ \\
\hline $\mathrm{Bi}$ & $60 \mathrm{~cm}+$ & $2,5 \mathrm{YR} 2,5 / 4$ & Argilosa & $\begin{array}{c}\text { moderada } \\
\text { média } \\
\text { blocos } \\
\text { subangulares } \\
\end{array}$ & $\begin{array}{c}\text { dura, firme, plástica e } \\
\text { pegajosa }\end{array}$ \\
\hline \multicolumn{6}{|c|}{ Perfil IV- ARGISSOLO VEMELHO-AMARELO Distrófico típico - PVAd } \\
\hline A & $0-25 \mathrm{~cm}$ & 7,5YR 4/6 & Média & $\begin{array}{l}\text { forte média } \\
\text { blocos } \\
\text { subangulares }\end{array}$ & $\begin{array}{l}\text { extremamente dura, } \\
\text { extremamente firme, } \\
\text { muito plástica e } \\
\text { muito pegajosa }\end{array}$ \\
\hline $\mathrm{AB}$ & $25-45 \mathrm{~cm}$ & 7,5YR 5/8 & Média & $\begin{array}{l}\text { forte média } \\
\text { blocos } \\
\text { subangulares } \\
\end{array}$ & $\begin{array}{l}\text { extremamente dura, } \\
\text { firme, plástica e } \\
\text { muito pegajosa }\end{array}$ \\
\hline BA & $45-55 \mathrm{~cm}$ & 5YR 5/8 & Argilosa & $\begin{array}{c}\text { forte pequena } \\
\text { blocos } \\
\text { subangulares }\end{array}$ & $\begin{array}{l}\text { dura, firme, muito } \\
\text { plástica e pegajosa }\end{array}$ \\
\hline $\mathrm{Bt}$ & $55 \mathrm{~cm}+$ & 5YR 5/4 & Argilosa & $\begin{array}{c}\text { forte pequena } \\
\text { blocos } \\
\text { subangulares }\end{array}$ & $\begin{array}{l}\text { extremamente dura, } \\
\text { extremamente firme, } \\
\text { muito plástica e } \\
\text { muito pegajosa }\end{array}$ \\
\hline
\end{tabular}




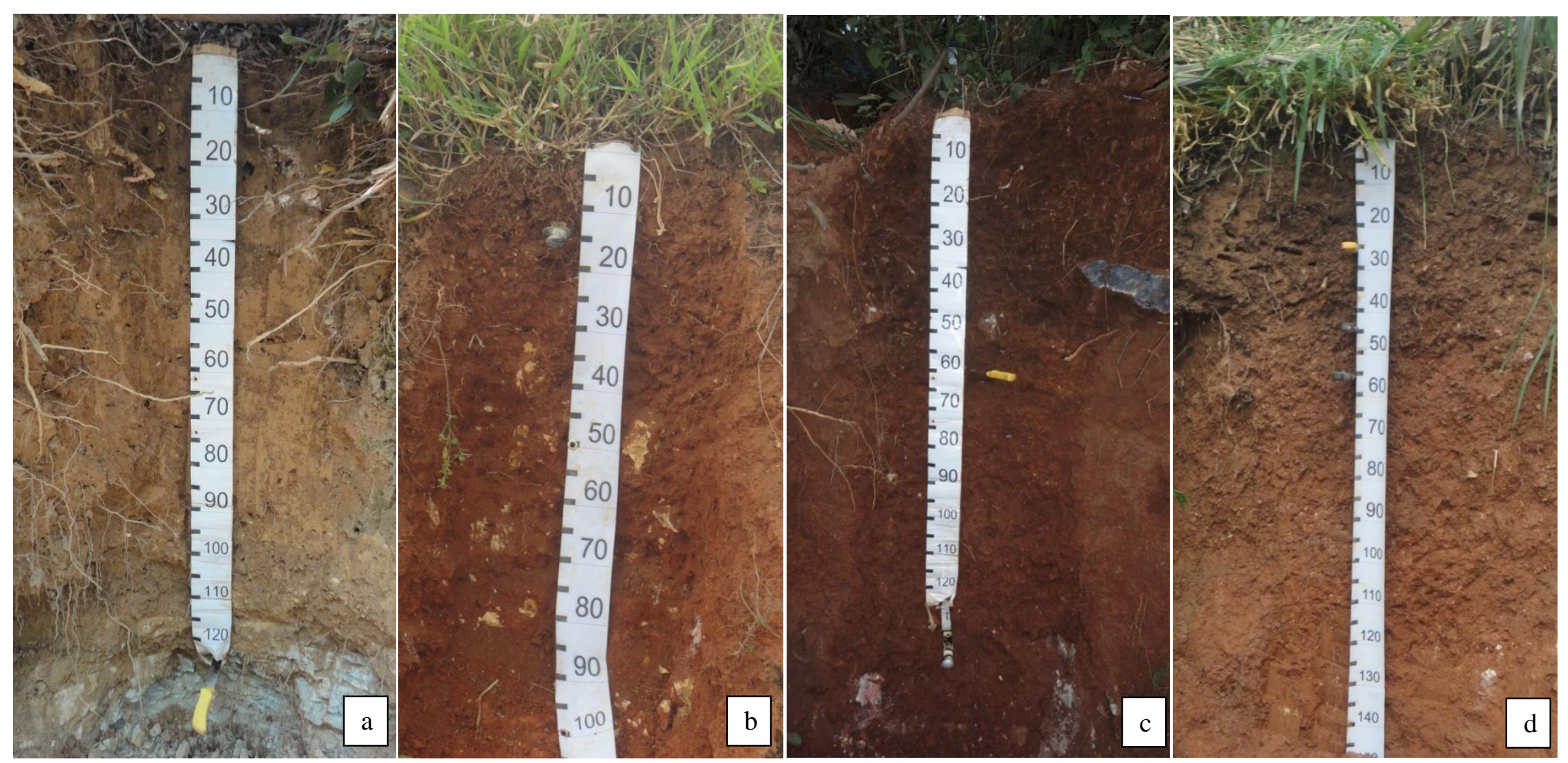

Figura 7. Foto da Geo-topossequência Catingueiro.(a) NITOSSOLO HÁPLICO Distrófico úmbrico, (b) ARGISSOLO VERMELHO Eutroférrico típico, (c) CHERNOSSOLO ARGILÚVICO Férrico típico, (d) ARGISSOLO VEMELHO-AMARELO Distrófico típico. 
Tabela 2. Características morfológicas do perfis da Geo-topossequência Pedreira.

\begin{tabular}{|c|c|c|c|c|c|}
\hline Horizonte & Profundidade & \begin{tabular}{c|} 
Cor \\
úmida \\
\end{tabular} & Textura & Estrutura & Consistência \\
\hline \multicolumn{6}{|c|}{ Perfil I - NITOSSOLO HÁPLICO Distrófico típico - NXd } \\
\hline $1 \mathrm{~A}$ & $0-13 \mathrm{~cm}$ & $5 Y R 4 / 6$ & Argilosa & $\begin{array}{c}\text { forte pequena } \\
\text { blocos } \\
\text { subangulares } \\
\end{array}$ & $\begin{array}{c}\text { extremamente dura, } \\
\text { firme, muito plástica } \\
\text { e pegajosa }\end{array}$ \\
\hline $2 \mathrm{~A}$ & $13-25 \mathrm{~cm}$ & $5 Y R 5 / 8$ & Argilosa & $\begin{array}{l}\text { forte média } \\
\text { blocos } \\
\text { subangulares }\end{array}$ & $\begin{array}{c}\text { extremamente dura, } \\
\text { firme, plástica e } \\
\text { muito pegajosa }\end{array}$ \\
\hline $\begin{array}{c}2 \mathrm{Bt} \\
\text { (nítico) }\end{array}$ & $25-45 \mathrm{~cm}$ & 7,5YR 7/8 & Argilosa & $\begin{array}{l}\text { forte média } \\
\text { blocos } \\
\text { subangulares }\end{array}$ & $\begin{array}{c}\text { extremamente dura, } \\
\text { extremamente firme, } \\
\text { muito plástica e } \\
\text { muito pegajosa }\end{array}$ \\
\hline $2 \mathrm{Btc}$ & $45 \mathrm{~cm}+$ & $5 Y R 5 / 6$ & Argilosa & $\begin{array}{c}\text { forte pequena } \\
\text { blocos } \\
\text { subangulares } \\
\end{array}$ & $\begin{array}{l}\text { dura, firme, muito } \\
\text { plástica e pegajosa }\end{array}$ \\
\hline \multicolumn{6}{|c|}{ Perfil II - NITOSSOLO VERMELHO Eutrófico chernossólico - NVe } \\
\hline $1 \mathrm{~A}$ & $0-35 \mathrm{~cm}$ & 10R 3/4 & Argilosa & $\begin{array}{c}\text { forte média } \\
\text { blocos angulares }\end{array}$ & $\begin{array}{l}\text { muito dura, firme, } \\
\text { plástica e pegajosa }\end{array}$ \\
\hline $2 \mathrm{AB}$ & $35-70 \mathrm{~cm}$ & 10R 4/4 & Argilosa & $\begin{array}{c}\text { forte média } \\
\text { blocos angulares }\end{array}$ & $\begin{array}{l}\text { muito dura, firme, } \\
\text { plástica e pegajosa }\end{array}$ \\
\hline Bt (nítico) & $70-130 \mathrm{~cm}$ & $10 \mathrm{R} 4 / 3$ & $\begin{array}{c}\text { Muito } \\
\text { Argilosa }\end{array}$ & $\begin{array}{c}\text { forte média } \\
\text { blocos angulares }\end{array}$ & $\begin{array}{l}\text { muito dura, firme, } \\
\text { plástica e pegajosa }\end{array}$ \\
\hline \multicolumn{6}{|c|}{ Perfil III - NITOSSOLO VERMELHO Eutrófico chernossólico - NVe } \\
\hline A & $0-65 \mathrm{~cm}$ & $10 \mathrm{R} 4 / 3$ & Argilosa & $\begin{array}{c}\text { forte grande } \\
\text { blocos angulares }\end{array}$ & $\begin{array}{l}\text { muito dura, firme, } \\
\text { plástica e pegajosa }\end{array}$ \\
\hline $\mathrm{AB}$ & $65-95 \mathrm{~cm}$ & 10R 4/8 & Argilosa & $\begin{array}{c}\text { forte grande } \\
\text { blocos angulares }\end{array}$ & $\begin{array}{l}\text { muito dura, firme, } \\
\text { plástica e pegajosa }\end{array}$ \\
\hline Bt (nítico) & $95-126 \mathrm{~cm}$ & 10R 4,5/8 & $\begin{array}{c}\text { Muito } \\
\text { Argilosa }\end{array}$ & $\begin{array}{c}\text { forte muito } \\
\text { grande } \\
\text { blocos angulares }\end{array}$ & $\begin{array}{l}\text { muito dura, firme, } \\
\text { plástica e pegajosa }\end{array}$ \\
\hline
\end{tabular}

Outra característica morfológica observada nos perfis estudados e que pode ser essencial na definição dos horizontes B textural e B nítico é a presença da cerosidade (Embrapa, 2013) que na classe dos Argissolos (solos com horizonte B textural) apresenta-se moderada e comum, enquanto na classe dos Nitossolos (solos com horizonte B nítico) mostra-se moderada a forte e comum. Na classe dos Chernossolos (solos com horizonte B incipiente ou B textural, no contexto da microbacia do Ribeirão Salinas) a cerosidade no horizonte B diagnóstico foi pouco expressiva (Tabelas1, 2 e 3). 


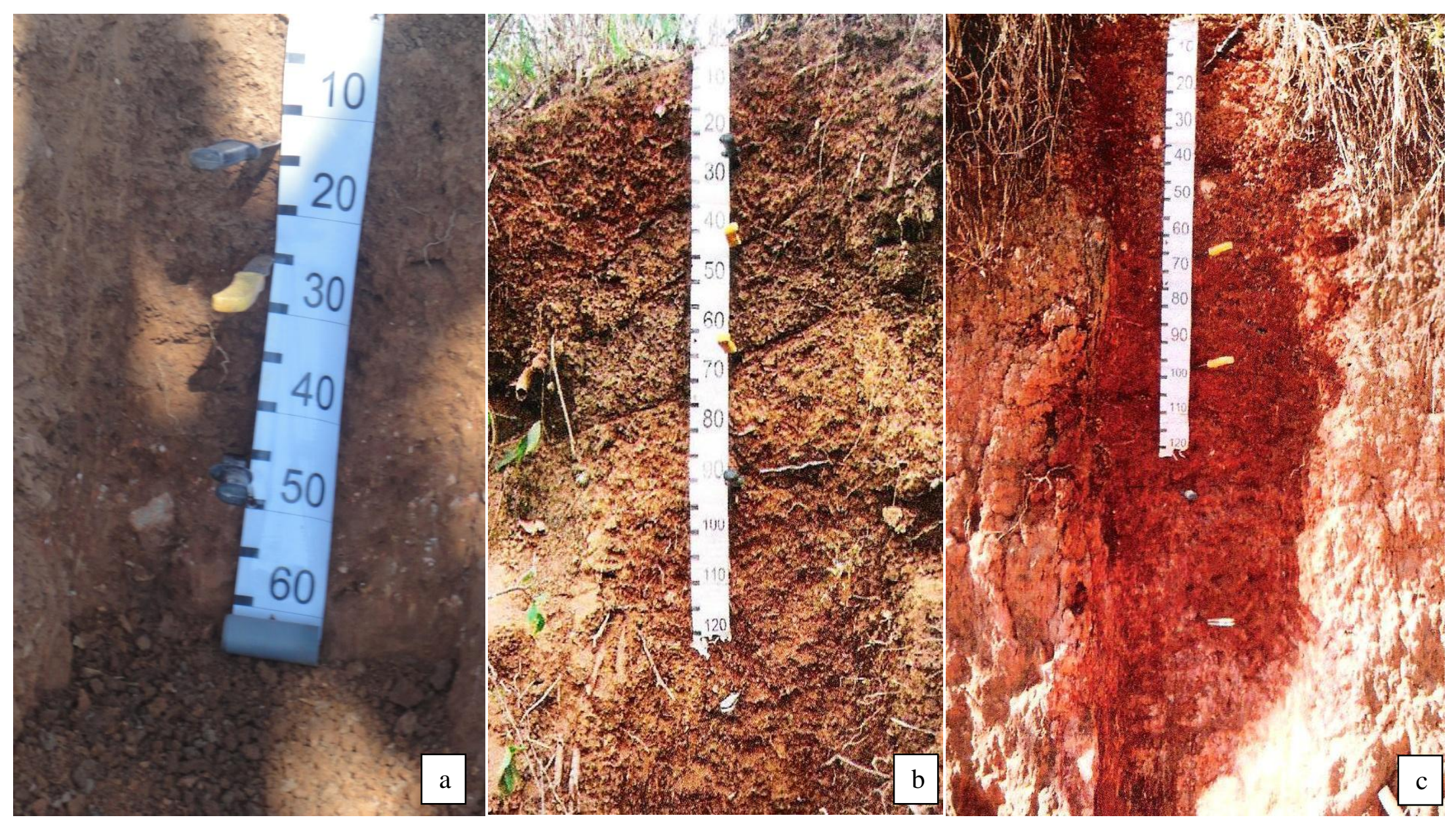

Figura 8. Foto da Geo-topossequência Pedreira. (a) NITOSSOLO HÁPLICO Distrófico típico, (b) NITOSSOLO VERMELHO Eutrófico chernossólico, (c) NITOSSOLO VERMELHO Eutrófico chernossólico. 
Tabela 3. Características morfológicas do perfis da Geo-topossequência DF-205.

\begin{tabular}{|c|c|c|c|c|c|}
\hline \multirow[t]{2}{*}{ Horizonte } & \multirow[t]{2}{*}{ Profundidade } & Cor & \multirow[t]{2}{*}{ Textura } & \multirow[t]{2}{*}{ Estrutura } & \multirow[t]{2}{*}{ Consistência } \\
\hline & & Úmida & & & \\
\hline \multicolumn{6}{|c|}{ Perfil I - CHERNOSSOLO HÁPLICO Férrico típico - MXf } \\
\hline A & $0-18 \mathrm{~cm}$ & 10R 4/2 & Argilosa & $\begin{array}{c}\text { moderada } \\
\text { média } \\
\text { blocos } \\
\text { subangulares }\end{array}$ & $\begin{array}{l}\text { dura, firme, plástica e } \\
\text { pegajosa }\end{array}$ \\
\hline $\mathrm{Bi}$ & $18 \mathrm{~cm}+$ & $10 \mathrm{R} 5 / 2$ & Argilosa & $\begin{array}{l}\text { moderada } \\
\text { média } \\
\text { blocos } \\
\text { subangulares } \\
\end{array}$ & $\begin{array}{c}\text { dura, firme, plástica e } \\
\text { pegajosa }\end{array}$ \\
\hline \multicolumn{6}{|c|}{ Perfil II - ARGISSOLO VERMELHO Eutroférrico típico - PVef } \\
\hline A & $0-6 \mathrm{~cm}$ & $5 \mathrm{YR} 4 / 4$ & Média & $\begin{array}{c}\text { moderada } \\
\text { pequena } \\
\text { blocos } \\
\text { subangulares }\end{array}$ & $\begin{array}{c}\text { dura, firme, muito plástica } \\
\text { e pegajosa }\end{array}$ \\
\hline $\mathrm{AB}$ & $6-24 \mathrm{~cm}$ & $5 Y R 4 / 4$ & Média & $\begin{array}{c}\text { forte pequena } \\
\text { blocos } \\
\text { subangulares }\end{array}$ & $\begin{array}{l}\text { extremamente dura, } \\
\text { extremamente firme, } \\
\text { plástica e muito pegajosa }\end{array}$ \\
\hline Bt1 & $24-85 \mathrm{~cm}$ & 2,5YR 6/6 & Argilosa & $\begin{array}{l}\text { forte média } \\
\text { blocos } \\
\text { subangulares }\end{array}$ & $\begin{array}{l}\text { muito dura, muito firme, } \\
\text { plástica e muito pegajosa }\end{array}$ \\
\hline $\mathrm{Bt} 2$ & $85 \mathrm{~cm}+$ & 2,5YR 6/6 & Argilosa & $\begin{array}{c}\text { forte média } \\
\text { blocos } \\
\text { subangulares }\end{array}$ & $\begin{array}{c}\text { extremamente dura, } \\
\text { extremamente firme, muito } \\
\text { plástica e muito pegajosa }\end{array}$ \\
\hline \multicolumn{6}{|c|}{ Perfil III - NITOSSOLO VERMELHO Distroférrico típico - NVf } \\
\hline A & $0-41 \mathrm{~cm}$ & $5 Y R 4 / 4$ & Argilosa & $\begin{array}{l}\text { forte média } \\
\text { blocos } \\
\text { angulares }\end{array}$ & $\begin{array}{l}\text { extremamente dura, firme, } \\
\text { muito plástica e pegajosa }\end{array}$ \\
\hline $\mathrm{AB}$ & $41-59 \mathrm{~cm}$ & $5 \mathrm{YR} 4 / 6$ & Argilosa & $\begin{array}{l}\text { forte média } \\
\text { blocos } \\
\text { angulares }\end{array}$ & $\begin{array}{l}\text { extremamente dura, firme, } \\
\text { muito plástica e pegajosa }\end{array}$ \\
\hline $\begin{array}{c}\mathrm{Bt} \\
\text { (nítico) }\end{array}$ & $59 \mathrm{~cm}+$ & $2,5 \mathrm{YR} 4 / 8$ & Argilosa & $\begin{array}{l}\text { forte média } \\
\text { blocos } \\
\text { angulares }\end{array}$ & $\begin{array}{c}\text { extremamente dura, firme, } \\
\text { plástica e pegajosa }\end{array}$ \\
\hline
\end{tabular}

Silva et al. (2013) estudando a gênese e classificação dos solos em uma topossequência em uma área cárstica na Serra da Bodoquena, MS, observaram Argissolos com presença de cerosidade - indicativa da iluviação de argila, comum a abundante nos horizontes Bt1 e Bt2 de um Argissolo Vermelho eutrófico nitossólico, e comum no horizonte Bt1 de um Argissolo Vermelho distrófico típico.

Segundo Embrapa (1978) os Argissolos da porção noroeste do Distrito Federal apresentam cerosidade de comum a abundante e de moderada a forte. 


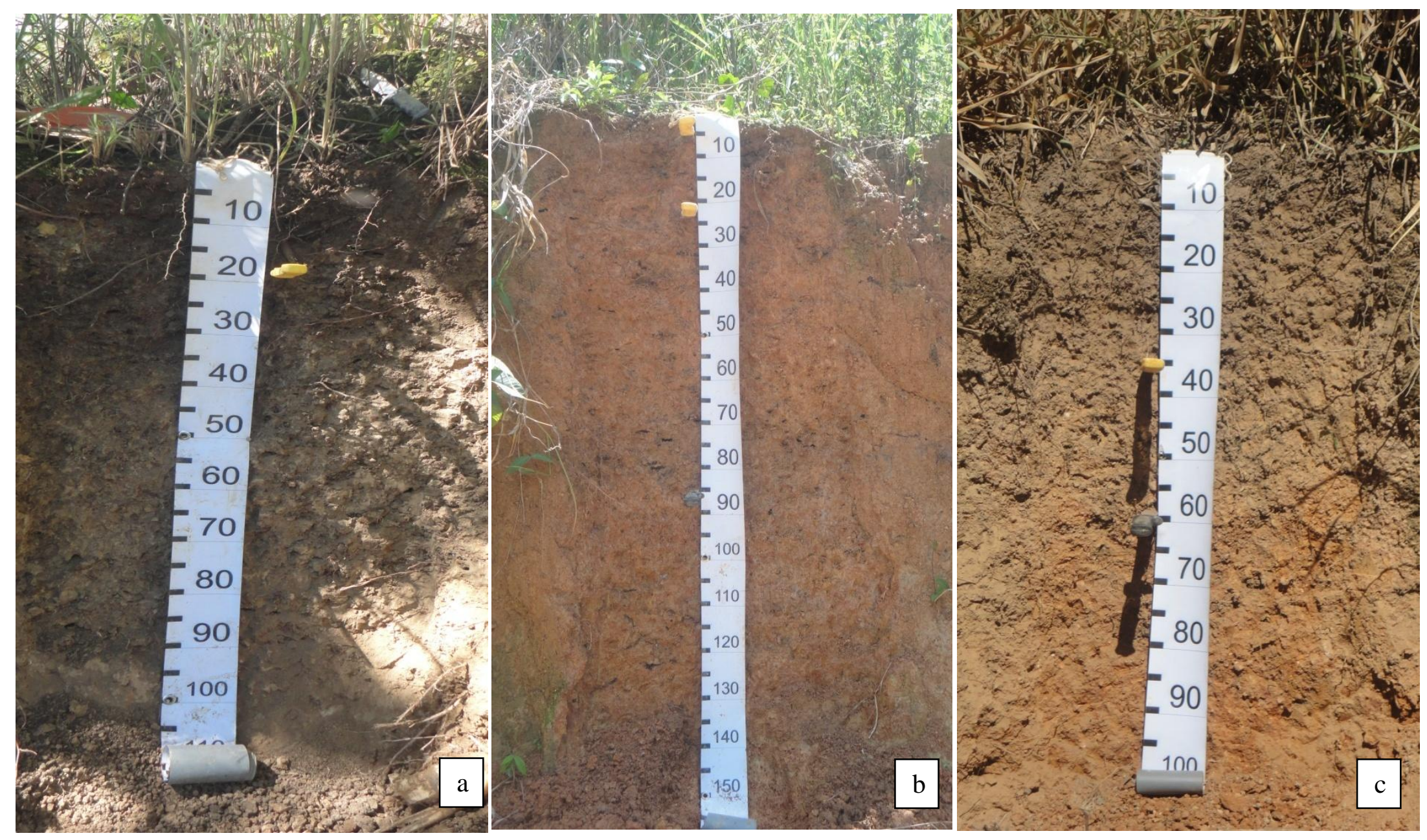

Figura 9. Foto da Geo-topossequência DF-205. (a) CHERNOSSOLO HÁPLICO Férrico típico (b) ARGISSOLO VERMELHO Eutroférrico típico, (c) NITOSSOLO VERMELHO Distroférrico típico. 


\subsection{2 - Atributos Químicos}

Os resultados das análises químicas dos solos estudados estão apresentados nas tabelas 4, 5 e 6. Entre os atributos dos solos avaliados o $\mathrm{pH}$ em $\mathrm{H}_{2} \mathrm{O}$ apresentou variação de 4,8 a 6,5 e de 5,0 a 6,3 nos horizontes A e B respectivamente dos perfis das três geo-topossequências. Segundo Embrapa (2013) o pH dos solos pode ser classificado da seguinte forma: extremamente ácidos quando apresentarem valores de pH em $\mathrm{H}_{2} \mathrm{O}$ menores que 4,3; fortemente ácidos entre 4,3 e 5,3; moderadamente ácidos entre 5,4 e 6,5; solos praticamente neutros entre 6,6 e 7,3; moderadamente alcalinos entre 7,4 e 8,3 e fortemente alcalinos para os que possuem valores de $\mathrm{pH}$ maiores que 8,3. Os Nitossolos estudados foram classificados em fortemente ácidos, com apenas uma exceção: perfil II da Geo-topossequência Pedreira, Nitossolo Vermelho Eutrófico chernossólico, que apresentou $\mathrm{pH}$ 5,4 no horizonte $\mathrm{B}$ nítico; os Chernossolos e Argissolos foram classificados como moderadamente ácidos, exceto o perfil II da Geotopossequência DF-205, Argissolo Vermelho Eutroférrico típico, que apresentou pH 5,2 no horizonte Bt.

Verificou-se que acidez dos solos da região estudada é, então, considerada variável, particularmente em função do grau evolutivo dos mesmos e do material de origem, tal como verificado nos relatos de Motta et al. (2002) e Reatto et al. (2002b) que caracterizaram os Argissolos e Nitossolos na região da Terceira Superfície Geomorfológica do Planalto Central Brasileiro, observando que o $\mathrm{pH}$ dos solos em ambas as classes apresentaram-se moderadamente ácidos nos horizontes A e B diagnóstico. Já no Levantamento de Reconhecimento de Solos realizado por Embrapa (1978) os Argissolos da Superfície Geomorfológica mais recente do DF, variam de forte a moderadamente ácidos, os Nitossolos variam de moderadamente ácidos a praticamente neutros e os Chernossolos podem variar de moderadamente ácidos a moderadamente alcalinos.

Os Nitossolos estudados corroboram a variação da acizez dos solos em função do estágio de evolução, visto que, pelo fato de apresentarem maior evolução pedogenética que os demais tendem a ser mais ácidos.

Pereira et al. (2012) observaram que os Chernossolos desenvolvidos a partir de calcários na Serra da Bodoquena, MS, representados pelo Chernossolo Háplico Órtico típico (MXo) e o Chernossolo Argilúvico Órtico típico (MTo) apresentaram pH 7,3 e 7,4 no horizonte $\mathrm{B}$ diagnóstico, sendo classificados como praticamente neutro e 
moderadamente alcalino, respectivamente. Segundo estes autores esse comportamento é decorrente da influência do material de origem.

Os Chernossolos e Nitossolos Vermelhos com horizonte A chernozêmico apresentaram valores elevados de soma de bases, capacidade de troca de cátions e alta concentração dos íons $\mathrm{Ca}^{2+}+\mathrm{Mg}^{2+}$, além de caráter eutrófico (Tabelas 4, 5 e 6). A formação de horizonte A chernozêmico nesta região do Planalto Central do Brasil, com clima tropical, apesar de sazonal, com duas estações (seca e chuvosa) bem definidas não é esperada, uma vez que o processo de formação deste horizonte é a calcificação, que ocorre em regiões de clima pouco ativo, com baixa precipitação pluviométrica ou com temperaturas mais baixas (Resende et al., 2007).

A evolução dos solos sob as condições climáticas da microbacia do Ribeirão Salinas não favorece a acumulação de $\mathrm{CaCO}_{3}$ em quantidade suficiente para reconhecimento do horizonte cálcico, petrocálcico ou de caráter carbonático e hipocarbonático nos perfis avaliados, embora desenvolvidos de materiais de origem de natureza carbonática (Silva et al., 2013)

Miranda e Ferreira (1999) caracterizaram solos com horizonte A chernozêmico na Zona da Mata Norte de Pernambuco verificando que estes solos são saturados por bases com dominância dos íons cálcio e magnésio, tanto em superfície quanto em subsuperfície, caracterizando o caráter eutrófico dos mesmos. Tal fato foi observado nos solos estudados, conforme dados apresentados nas tabelas 4, 5 e 6).

Esses autores justificam a ocorrência de solos com horizonte A chernozêmico nessa região, possivelmente, em função desses horizontes superficiais terem sua formação ligada a interações do clima e vegetação, haja visto que, apesar das condições tropicais da região, esses solos se mantêm com uma boa reserva química, provavelmente, graças à ocorrência de uma estação mais seca e prolongada, que provoca estresse hídrico na vegetação, com a queda de folhas e reduz a lixiviação de bases, conferindo significativa incorporação do material orgânico, o qual se decompõe e permanece bastante humificado no perfil. Já no contexto da microbacia do Ribeirão Salinas a interação desses fatores (clima e vegetação) é menos atuante, sendo os fatores responsáveis pela formação dos horizontes A chernozêmicos e os Chernossolos correpondentes nesta região do Planalto Central do Brasil, a atuação do material de origem, que é constituído por rochas carbonatadas do Grupo Canastra e secundariamente Grupo Paranoá, com ocorrência de diversas lentes de metacalcários, em um pedoambiente imaturo (Figueiredo et al., 2004, Silva et al., 2013). 
Pereira et al. (2012) observaram o desenvolvimento de Chernossolos sobre calcário na Serra da Bodoquena, MS, verificando que a ocorrência dessa classe de solo é condicionada pelo material de origem, constituído por rochas de natureza calcária, com influência de sedimentos coluviais do calcário das partes mais altas e pelo relevo, que condiciona a drenagem e o escoamento superficial.

Tabela 4. Análises Químicas dos solos da Geo-topossequência Catingueiro.

\begin{tabular}{|c|c|c|c|c|c|c|c|c|c|c|c|c|c|}
\hline \multirow[t]{2}{*}{ Horizontes } & pH & $\mathrm{Ca}^{2+}+\mathrm{Mg}^{2+}$ & $\mathbf{K}^{+}$ & $\mathbf{A l}^{3^{+}}$ & $\mathbf{H}^{+}+\mathbf{A} \mathbf{l}^{3^{+}}$ & $\mathbf{S}$ & $\mathbf{t}$ & $\mathbf{T}$ & $\mathbf{V}$ & m & T argila & M.O & $\mathbf{C}_{\text {org }}$ \\
\hline & $\mathrm{H}_{2} \mathrm{O}$ & \multicolumn{7}{|c|}{$\mathrm{cmol}_{\mathrm{c}} \mathrm{dm}^{-3}$} & \multicolumn{2}{|c|}{$\%$} & $\mathrm{cmol}_{\mathrm{c}} \cdot \mathrm{dm}^{-3}$ & \multicolumn{2}{|c|}{$\mathrm{gkg}^{-1}$} \\
\hline \multicolumn{14}{|c|}{ Perfil I - NITOSSOLO HÁPLICO Distrófico úmbrico - NXd } \\
\hline A & 5,2 & 3,7 & 0,83 & 0,65 & 7,23 & 4,53 & 5,18 & 11,79 & 38,40 & 12,56 & 28,56 & 38,84 & 22,53 \\
\hline Bt (nítico) & 5,0 & 0,9 & 0,33 & 1,80 & 5,61 & 1,23 & 3,03 & 6,84 & 17,93 & 59,49 & 13,88 & 16,83 & 9,76 \\
\hline \multicolumn{14}{|c|}{ Perfil II - ARGISSOLO VERMELHO Eutroférrico típico - Pvef } \\
\hline A & 5,4 & 3,1 & 0,43 & 0,00 & 4,50 & 3,53 & 26,11 & 8,50 & 47,00 & 0,00 & 26,11 & 41,00 & 23,78 \\
\hline Bt & 5,8 & 3,1 & 0,32 & 0,00 & 2,00 & 3,42 & 10,83 & 5,40 & 63,00 & 0,00 & 10,83 & 15,00 & 8,70 \\
\hline \multicolumn{14}{|c|}{ Perfil III - CHERNOSSOLO ARGILÚVICO Férrico típico - MTf } \\
\hline A & 6,5 & 19,3 & 0,39 & 0,00 & 3,47 & 19,69 & 19,69 & 23,15 & 85,04 & 0,00 & 62,10 & 47,9 & 27,78 \\
\hline $\mathrm{Bi}$ & 6,3 & 17,4 & 0,19 & 0,00 & 2,64 & 17,59 & 17,59 & 20,23 & 86,95 & 0,00 & 42,79 & 11,65 & 6,75 \\
\hline \multicolumn{14}{|c|}{ Perfil IV - ARGISSOLO VERMELHO-AMARELO Distrófico típico - PVAd } \\
\hline A & 6,0 & 4,9 & 0,50 & 0,00 & 4,00 & 5,40 & 25,71 & 9,40 & 57,00 & 0,00 & 25,71 & 43,00 & 24,94 \\
\hline $\mathrm{Bt}$ & 5,8 & 2,2 & 0,23 & 2,00 & 4,30 & 2,43 & 11,06 & 6,70 & 36,00 & 45,00 & 11,06 & 14,00 & 8,12 \\
\hline
\end{tabular}


Tabela 5. Análises Químicas dos solos da Geo-topossequência Pedreira.

\begin{tabular}{|c|c|c|c|c|c|c|c|c|c|c|c|c|c|}
\hline \multirow[t]{2}{*}{ Horizontes } & pH & $\mathrm{Ca}^{2+}+\mathrm{Mg}^{2+}$ & $\mathbf{K}^{+}$ & $\mathbf{A l}^{3^{+}}$ & $\mathrm{H}^{+}+\mathrm{Al}^{3^{+}}$ & $\mathbf{S}$ & $\mathbf{t}$ & $\mathbf{T}$ & $\mathbf{V}$ & $\mathbf{m}$ & $\mathbf{T}$ argila & M.O & $\mathrm{C}_{\text {org }}$ \\
\hline & $\mathrm{H}_{2} \mathrm{O}$ & \multicolumn{7}{|c|}{$\mathrm{cmol}_{\mathrm{c}} \mathrm{dm}^{-3}$} & \multicolumn{2}{|c|}{$\%$} & $\mathrm{cmol}_{\mathrm{c}} \cdot \mathrm{dm}^{-3}$ & \multicolumn{2}{|c|}{$\mathrm{gkg}^{-1}$} \\
\hline \multicolumn{14}{|c|}{ Perfil I - NITOSSOLO HÁPLICO Distrófico típico - NXd } \\
\hline A & 4,8 & 1,80 & 0,31 & 2,00 & 6,90 & 2,11 & 17,80 & 9,00 & 23,00 & 49,00 & 17,80 & 25,00 & 14,50 \\
\hline Bt ( nítico) & 4,9 & 1,70 & 0,24 & 1,80 & 5,60 & 1,94 & 13,43 & 7,50 & 25,00 & 49,00 & 13,43 & 20,00 & 11,60 \\
\hline \multicolumn{14}{|c|}{ Perfil II - NITOSSOLO VERMELHO Eutrófico chernossólico - NVe } \\
\hline A & 5,5 & 11,85 & 0,53 & 0,15 & 5,40 & 12,38 & 12,53 & 17,78 & 69,63 & 1,20 & 31,27 & 40,10 & 23,26 \\
\hline Bt (nítico) & 5,4 & 12,50 & 0,48 & 1,25 & 4,05 & 12,98 & 14,23 & 17,03 & 76,22 & 8,78 & 25,24 & 14,20 & 8,23 \\
\hline \multicolumn{14}{|c|}{ Perfil III - NITOSSOLO VERMELHO Eutrófico chernossólico - NVe } \\
\hline A & 4,8 & 9,90 & 0,17 & 2,05 & 5,52 & 10,07 & 12,12 & 15,30 & 65,74 & 16,91 & 29,73 & 32,30 & 18,73 \\
\hline Bt (nítico) & 5,1 & 9,95 & 0,09 & 1,75 & 3,90 & 10,04 & 11,79 & 13,94 & 72,03 & 14,84 & 21,85 & 11,60 & 6,73 \\
\hline
\end{tabular}
$\mathrm{Al}^{3+} ; \mathrm{T}$ argila $=(\mathrm{T} * 1000 /$ conteúdo de argila $)$

Tabela 6. Análises Químicas dos solos da Geo-topossequência DF-205.

\begin{tabular}{|c|c|c|c|c|c|c|c|c|c|c|c|c|c|}
\hline \multirow[t]{2}{*}{ Horizontes } & $\mathbf{p H}$ & $\mathrm{Ca}^{2+}+\mathrm{Mg}^{2+}$ & $\mathbf{K}^{+}$ & $\mathbf{A l}^{3^{+}}$ & $\mathbf{H}^{+}+\mathbf{A l}^{3^{+}}$ & $\mathbf{S}$ & $\mathbf{t}$ & $\mathbf{T}$ & $\mathbf{V}$ & $\mathbf{m}$ & T argila & M.O & $\mathbf{C}_{\text {org }}$ \\
\hline & $\mathrm{H}_{2} \mathrm{O}$ & \multicolumn{7}{|c|}{$\mathrm{cmol}_{\mathrm{c}} \mathrm{dm}^{-3}$} & \multicolumn{2}{|c|}{$\%$} & $\mathrm{cmol}_{\mathrm{c}} \cdot \mathrm{dm}^{-3}$ & \multicolumn{2}{|c|}{$\mathrm{gkg}^{-1}$} \\
\hline \multicolumn{14}{|c|}{ Perfil I - CHERNOSSOLO HÁPLICO Férrico típico - MXf } \\
\hline A & 5,5 & 7,7 & 0,18 & 0,0 & 4,3 & 7,88 & 34,04 & 12,2 & 65,00 & 0,0 & \multirow{2}{*}{$\begin{array}{l}33,76 \\
27,00\end{array}$} & 40,00 & 23,20 \\
\hline $\mathrm{Bi}$ & 6,1 & 7,5 & 0,32 & 0,0 & 2,3 & 7,82 & 26,69 & 10,1 & 77,00 & 0,0 & & 23,00 & 13,34 \\
\hline \multicolumn{14}{|c|}{ Perfil II - ARGISSOLO VERMELHO Eutroférrico típico - Pvef } \\
\hline A & 5,4 & 2,5 & 0,46 & 0,0 & 2,5 & 2,96 & 14,26 & 5,5 & 55,00 & 0,0 & \multirow{2}{*}{$\begin{array}{c}14,26 \\
8,37\end{array}$} & 25,00 & 14,50 \\
\hline $\mathrm{Bt}$ & 5,2 & 2,4 & 0,17 & 0,4 & 2,3 & 2,57 & 8,37 & 4,9 & 53,00 & 13,0 & & 10,00 & 5,80 \\
\hline \multicolumn{14}{|c|}{ Perfil III - NITOSSOLO VERMELHO Distroférrico típico - NVf } \\
\hline A & 5,7 & 1,1 & 0,48 & 0,2 & 4,5 & 1,58 & 13,10 & 6,1 & 26,00 & 11,0 & 13,10 & 27,00 & 15,66 \\
\hline Bt (nítico) & 5,2 & 0,3 & 0,10 & 0,8 & 3,8 & 0,40 & 7,17 & 4,2 & 10,00 & 67,0 & 7,17 & 14,00 & 8,12 \\
\hline
\end{tabular}

$\mathrm{S}=$ soma de bases $\left(\mathrm{Ca}^{2+}+\mathrm{Mg}^{2}+\mathrm{K}^{+}\right) ; \mathrm{T}=$ Capacidade de Troca Catiônica $\left(\mathrm{S}+\mathrm{H}^{+}+\mathrm{Al}^{+}\right) ; \mathrm{V} \%=$ saturação de bases $(100 \mathrm{x} \mathrm{S} / \mathrm{T}) ; \mathrm{m} \%=$ saturação por alumínio $\left(\mathrm{Al} \mathrm{3}^{+} * 100 / \mathrm{t}\right) ; \mathrm{t}=\mathrm{CTC}$ efetiva $=\mathrm{S}+$ $\mathrm{Al}^{3+} ; \mathrm{T}$ argila $=\left(\mathrm{T}^{*} 1000 /\right.$ conteúdo de argila $)$ 
Em contrapartida, o Argissolo Vermelho-Amarelo e os Nitossolos Háplicos da região estudada apresentaram baixos valores de soma de bases e de capacidade de troca de cátions. A classe dos Argissolos apresentou variação nos valores de saturação por bases, alguns perfis dessa classe de solos mostraram-se eutróficos e outros distróficos, enquanto os Nitossolos Háplicos apresentaram-se apenas distróficos (Tabelas 4, 5 e 6). Segundo Martins et al. (2004) no contexto do DF, os Argissolos consituem classe bastante heterogênea, sua fertilidade varia de acordo com o substrato geológico, podendo ser tanto distróficos quanto eutróficos. No geral, os Nitossolos são solos eutróficos, com elevada saturação por bases, mas como podem ocorrer sob diferentes substratos geológicos é possível encontrar solos representantes dessa classe com valores de fertilidade mais baixos.

Reatto et al. (2002b) realizando o Levantamento de Reconhecimento de Alta Intensidade dos Solos da APA de Cafuringa, DF observaram que na classe dos Argissolos a saturação por bases varia entre $30 \%$ e $80 \%$, nos Argissolos Vermelhos, e entre $40 \%$ e 50\%, nos Argissolos Vermelho-Amarelos, demonstrando que esses solos podem ser tanto eutróficos como distróficos. Já os Nitossolos estudados por estes autores, representados pelos Nitossolos Vermelhos, são solos eutróficos com saturação por bases em torno de $80 \%$. Semelhante aos Nitossolos, os Chernossolos avaliados são solos eutróficos, com elevados valores de saturação por bases.

O caráter eutrófico e distrófico dos solos avaliados está diretamente relacionado a natureza do material de origem. Os Chernossolos e os Nitossolos com horizonte A chernozêmico da área de estudo desenvolveram-se a partir de rochas carbonatadas, representadas, em parte, por fácies de filitos carbonosos bastante ricas em matéria orgânica, concordando com o estudo de Martins et al. (2004). Tal fato é refletido no comportamento químico dos solos desenvolvidos a partir dessas rochas, como os

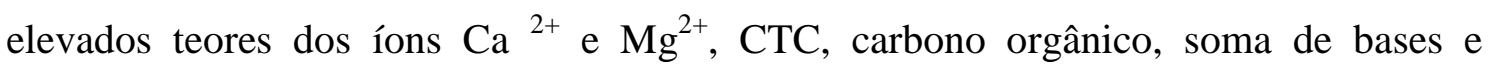
saturação por bases. O Argissolo Vermelho-Amarelo distrófico formou-se, provavelmente, a partir de sericita-filitos, litologias mais pobres em elementos nutrientes, sendo que esses materiais são constituídos basicamente de $\mathrm{SiO}_{2}, \mathrm{Al}_{2} \mathrm{SO}_{3}$, $\mathrm{K}_{2} \mathrm{O}$ e $\mathrm{H}_{2} \mathrm{O}$ (Machado et al., 2013). Desta forma, os solos originados a partir destas rochas apresentam baixos valores de CTC, soma de bases e saturação por bases. Já os Nitossolos e os Argissolos Vermelhos eutróficos originaram-se a partir de clorita filitos, que são litologias enriquecidas em $\mathrm{Fe}$ e $\mathrm{Mg}$, e formam solos com boas características químicas, como elevada CTC, soma de bases e saturação por bases. A existência de 
Nitossolos distróficos na região estudada está relacionada com o grau de evolução destes solos, uma vez que a evolução pedogenética proporciona a lixiviação dos elementos nutrientes, proporcionado o caráter distrófico, a acidez com a consequente diminuição da fertilidade natural.

Quanto ao teor de matéria orgânica $(\mathrm{MO})$ e carbono orgânico $\left(\mathrm{C}_{\mathrm{org}}\right)$, a maioria dos solos estudados apresentou valores elevados (Tabelas 4, 5 e 6), o que pode ser justificado em função de grande parte dos perfis descritos apresentarem desenvolvimento de vegetação nativa correspondente à fitofisionomia Mata Seca Semidecídua. Esta vegetação nativa é distinta das fitofisionomias do Cerrado, que predominam no Planalto Central do Brasil. O desenvolvimento da Mata Seca Semidecídua está relacionada à fertilidade natural dos solos, que se desenvolvem na Terceira Superfície Geomorfológica do DF. Esta superfície correponde à mais jovem do DF, com relevos ondulados a montanhosos, demonstrando dissecação ativa com grande percolação de água, estando de acordo com o trabalho de Motta et al. (2002).

Os perfis que apresentam valores mais baixos; $10,00 \mathrm{gkg}^{-1}$ de $\mathrm{MO}$ e 5,80 $\mathrm{gkg}^{-1}$ de $\mathrm{C}_{\text {org }}$ no horizonte $\mathrm{Bt}$ (Argissolo Vermelho Eutroférrico típico, perfil II Geotopossequência DF-205); $14,00 \mathrm{gkg}^{-1}$ de $\mathrm{MO}$ e $8,12 \mathrm{gkg}^{-1}$ de $\mathrm{C}_{\text {org }}$ no horizonte $\mathrm{Bt}$ (nítico) (Nitossolo Vermelho Distroférrico típico, perfil III da Geo-topossequência DF205), encontram-se locais com conversão da vegetação nativa em pastagens, justificando o decréscimo de $\mathrm{MO}$ e $\mathrm{C}_{\text {org. }}$. O conteúdo de carbono orgânico reduz com a profundidade dos solos, fazendo com que os teores no horizonte A sejam mais elevados em relação ao horizonte B diagnóstico assim como observado nos trabalhos de Motta et al. (2002), Reatto et al. (2002b), Barbosa et al. (2009) e Pereira et al. (2012).

Segundo Figueiredo et al. (2008) a importância da matéria orgânica nos atributos do solos é abrangente. Ela atua tanto na melhoria das condições físicas, como na aeração, maior retenção e armazenamento de água, quanto nas propriedades químicas e físico-químicas, no fornecimento de nutrientes às plantas e na maior capacidade de troca catiônica do solo (CTC) além de proporcionar um ambiente adequado ao estabelecimento da microbiota.

Os Chernossolos são solos que, por definição, segundo Embrapa (2013) apresentam alta atividade da fração argila (Ta) no horizonte B diagnóstico. Assim, o Chernossolo Argilúvico Férrico típico (perfil III da Geo-topossequência Catingueiro) e o Chernossolo Háplico Férrico típico (perfil I da Geo-topossequência DF-205) 
apresentam em seus horizontes B diagnósticos valores altos da atividade da argila, classificados como Ta ( $\mathrm{T}$ argila $\geq 27 \mathrm{cmol}_{\mathrm{c}} \cdot \mathrm{kg}^{-1}$ ) (Tabelas 4, 5 e 6).

No presente estudo as variações nos atributos químicos verificadas entre as classes de solos que apresentam horizonte B textural e Bt (nítico), preferencialmente, se dão, principalmente, em função do grau de evolução e da herança da composição geoquímica e mineralógica do material de origem destes solos.

Os perfis das Geo-topossequências Catingueiro, Pedreira e DF-205 foram originados a partir de rochas pelito-carbonatadas do Grupo Paranoá e rochas carbonatadas do Grupo Canastra. As rochas do Grupo Paranoá são constituídas por metassiltitos e metargilitos com lentes meta-calcárias. Já as rochas do Grupo Canastra, são constituídas essencialmente por filitos variados, os quais incluem clorita filitos, quartzo-fengita filitos e clorita-carbonato filitos. Além dos filitos ocorrem subordinadamente, na forma de lentes decamétricas, mármores finos cinza-claros e quartzitos finos silicificados e cataclasados (Freitas-Silva e Campos, 1998). Desta forma, o substrato geológico da microbacia do Ribeirão Salinas apresenta litologias, particularmente as do Grupo Canastra, enriquecidas em nutrientes minerais, que são preservados nos solos com horizonte B textural e B nítico estudados, sendo refletido no comportamento químico destes solos.

\subsection{3 - Atributos Físicos}

Os atributos físicos estudados foram textura, densidade, gradiente textural e relação silte/argila. Os resultados das análises físicas dos perfis avaliados são apresentados nas tabelas 7,8 e 9 .

A textura dos solos não apresentou variação significativa entre os perfis das três geo-topossequências estudadas. A classe dos Argissolos apresentou textura média no horizonte A e textura argilosa no horizonte Bt. Os Nitossolos apresentaram textura argilosa no horizonte A e textura variando de argilosa a muito argilosa no horizonte $\mathrm{Bt}$ (nítico). Os Chernossolos apresentaram textura argilosa em ambos horizontes. Os Argissolos que apresentam textura média/argilosa e os Nitossolos com textura argilosa/muito argilosa (Tabelas 7, 8 e 9) demonstram bem o processo de formação destes solos, por translocação de argila do horizonte A para o horizonte B (Embrapa, 2013). 
Tabela 7. Análises Físicas dos solos dos perfis da Geo-topossequência Catingueiro.

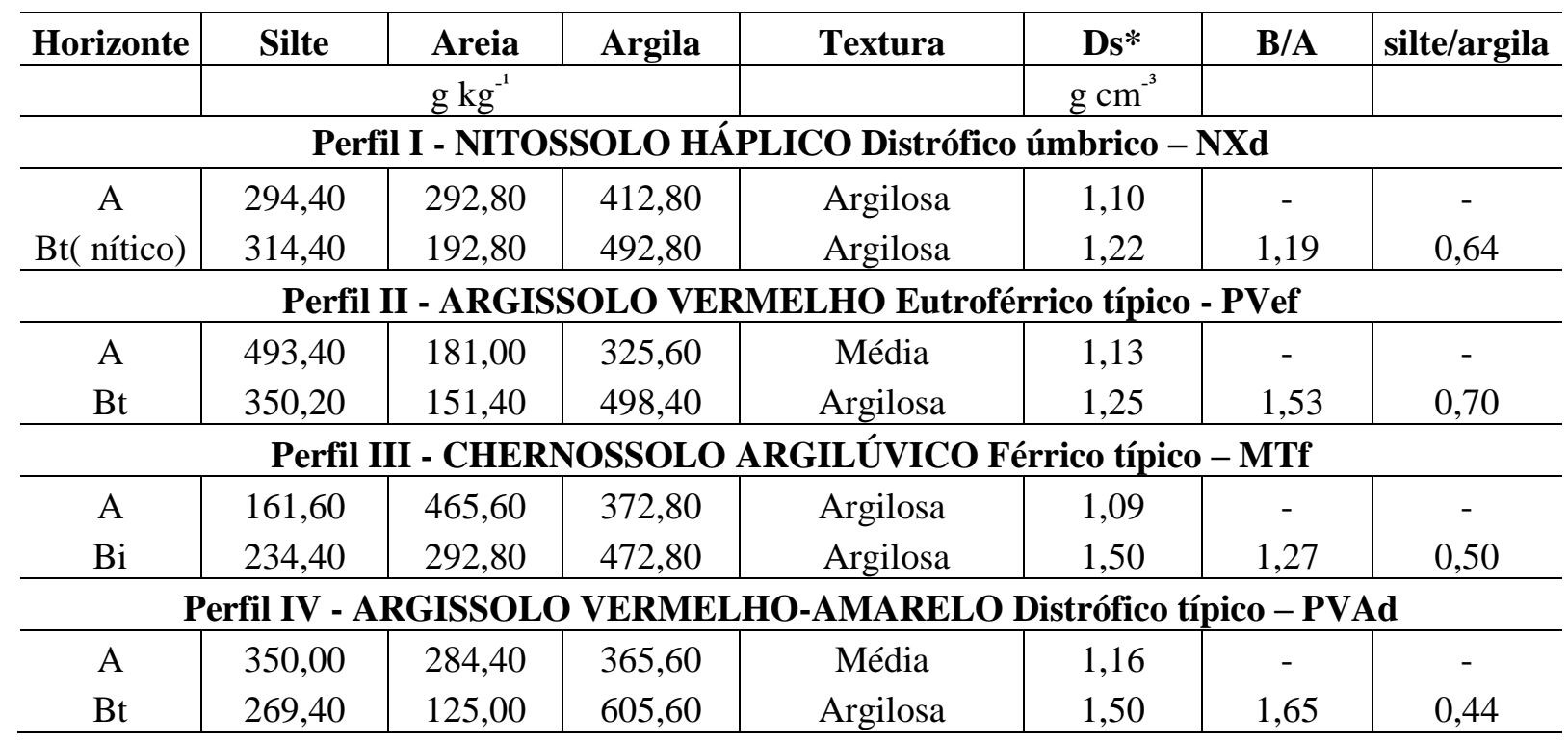

Tabela 8. Análises Físicas dos solos dos perfis da Geo-topossequência Pedreira.

\begin{tabular}{c|c|c|c|c|c|c|c}
\hline Horizonte & Silte & Areia & Argila & Textura & Ds* & B/A & silte/argila \\
\hline \multicolumn{7}{c}{ Perfil I - NITOSSOLO HÁPLICO Distrófico típico- NXd } \\
\hline A & 282,60 & 211,80 & 505,60 & Argilosa & 1,26 & - & - \\
\hline Bt( nítico) & 194,40 & 247,20 & 558,40 & Argilosa & 1,33 & 1,10 & 0,35 \\
\hline \multicolumn{7}{c}{ Perfil II- NITOSSOLO VERMELHO Eutrófico chernossólico - NVe } \\
\hline A & 276,00 & 155,40 & 568,60 & Argilosa & 1,23 & - & - \\
Bt( nítico) & 216,90 & 108,50 & 674,60 & Muito argilosa & 1,36 & 1,19 & 0,32 \\
\hline \multicolumn{7}{c}{ Perfil III -NITOSSOLO VERMELHO Eutrófico chernossólico- NVe } \\
\hline A & 241,80 & 243,40 & 514,70 & Argilosa & 1,50 & - & - \\
Bt( nítico) & 233,80 & 128,40 & 637,90 & Muito argilosa & 1,24 & 1,24 & 0,37 \\
\hline
\end{tabular}

Tabela 9. Análises Físicas dos solos dos perfis da Geo-topossequência DF-205.

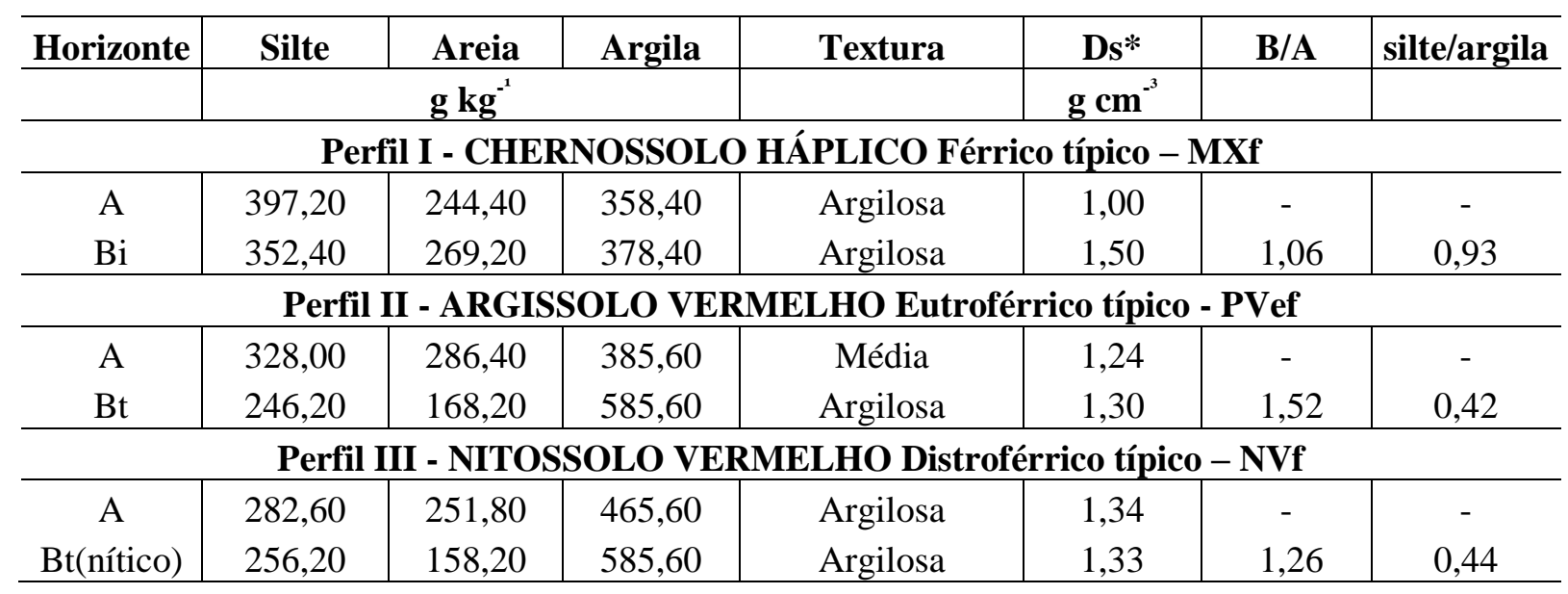


Os solos estudados são argilosos, mostrando relação textural com os seus materiais de origem, uma vez que foram originados de rochas pelito-carbonatadas dos Grupos Paranoá e Canastra, concordando com Vieira et al. (2007) que relatam que a textura, um dos atributos mais estáveis do solo, é dependente do material originário e dos agentes naturais de formação do solo, não sendo alterada pelo cultivo e outras práticas agrícolas. Entretanto, a erosão diferencial pode promover, na camada superficial do solo, pequenas variações na proporção das frações granulométricas. Qualquer outra causa de variabilidade na textura do solo se deve à variabilidade em material de origem ou o grau de evolução do solo.

Quanto a densidade do solo (Ds), esta foi pouco variável nos horizontes diagnósticos com valores entre $1,22 \mathrm{~g} \cdot \mathrm{cm}^{-3}$ a $1,36 \mathrm{~g} \cdot \mathrm{cm}^{-3}$, nos Nitossolos, $1,25 \mathrm{~g} \cdot \mathrm{cm}^{-3}$ a 1,50g. $\mathrm{cm}^{-3}$, nos Argissolos e 1,00g.cm ${ }^{-3}$ a 1,09g. $\mathrm{cm}^{-3}$ nos Chernossolos (Tabelas 7, $8 \mathrm{e}$ 9). Os valores de Ds dos solos avaliados estão em conformidade com Silva et al. (2013) que encontraram valores de densidade em Argissolos variando de 1,41g.cm- ${ }^{3}$ a 1,56g.cm- ${ }^{3}$, na classe dos Nitossolos e segundo Costa (2012), esse atributo variou de 1,01g.cm- ${ }^{3}$ a 1,36g.cm- ${ }^{3}$. Já Pereira et al. (2012) encontraram valores de densidade do solo de $0,78 \mathrm{~g} . \mathrm{cm}^{-3}$ a $1,25 \mathrm{~g} . \mathrm{cm}^{-3}$ no horizonte A chernozêmico dos Chernosssolos, onde a baixa Ds no horizonte $\mathrm{A}$ reflete o elevado teor de $\mathrm{C}$ orgânico deste horizonte diagnóstico, tal como observado nos Chernossolos estudados (Tabelas 7 e 9).

A densidade do solo é um importante atributo físico dos solos, por fornecer indicações a respeito do estado de sua conservação, sobretudo em sua influência em propriedades como infiltração e retenção de água no solo, desenvolvimento de raízes, trocas gasosas e suscetibilidade desse solo aos processos erosivos, e também sendo largamente utilizada na avaliação da compactação e/ou adensamento dos solos (Guariz, 2009).

A densidade do solo é uma propriedade que pode variar com a atuação de alguns componentes do sistema, como a matéria orgânica e o cultivo intensivo. A densidade recebe uma influência benéfica da matéria orgânica, que melhora a agregação do solo e, com isso, promove a redução desta propriedade. Por outro lado, o cultivo intensivo provoca a quebra dos agregados do solo e, como conseqüiência, ocorre o aumento da densidade e diminuição da porosidade, o que pode influir na aeração e na infiltração da água. Esse atributo tende a aumentar com a profundidade, normalmente, por influência de fatores como o teor reduzido de matéria orgânica, menor agregação e maior 
compactação (Kiehl, 1979). Estes fatores não influenciam os solos estudados que, na maioria, encontram-se com desenvolvimento de vegetação nativa.

O perfil III da Geo-topossequência Pedreira - NVe e o perfil III da Geotopossequência DF-205, NVf apresentaram valores de densidade superiores no horizonte de superfície contradizendo os trabalhos de Miranda e Ferreira (1999), Santos et al. (2010) e Pereira et al. (2012).

No que diz respeito ao gradiente textural, este variou de 1,06 a 1,26, nos Nitossolos, de 1,06 a 1,27 nos Chernossolos e de 1,52 a 1,66, nos Argissolos (Tabelas 5, 6 e 7). Segundo Embrapa (2013) este atributo físico tem grande importância na distinção entre Argissolos e Nitossolos.

A relação silte/argila apresentou variação irregular nos perfis das três geotopossequências. A maioria dos perfis estudados apresentaram relação silte/argila inferior a 0,6, exceto os perfis I (NXd) e II (PVef) da Geo-topossequência Catingueiro e o perfil I (MXf) da Geo-topossequência DF-205 (Tabelas 5, 6 e 7). Observando os valores encontrados é possível perceber que este parâmetro se enquadrou bem para a classe dos Nitossolos, que são solos bem desenvolvidos e com grau de intemperismo mais acentuado, porém não foi um bom parâmetro para as demais classes de solos encontradas na área de estudo, como Argissolos e Chernossolos. Nessas classes de solos espera-se que a relação silte/argila apresente valores superiores a 0,6, uma vez que se tratam de solos jovens, que sofreram pouca ação do intemperismo. $\mathrm{O}$ resultado mais anômalo foi do perfil III da Geo-topossequência Catingueiro (MTf) que apresentou relação silte/argila inferior a 0,6 , mesmo apresentando horizonte B incipiente.

Pode-se justificar os baixos valores da relação silte/argila nos solos avaliados, visto que o material de origem, tanto do Grupo Parnoá quanto do Grupo Canastra tratam-se de litologias pré intemperizadas na sua origem, que foi a gênese sedimentar, concordando com Moreau et al. (2006), que relatam que a relação silte/argila é própria do material de origem, não expressando bem a maturidade genética do solo.

Andrade et al. (1997) advertem que a relação silte/argila deve ser avaliada com cautela, pois em certos casos, a fração silte é constituída virtualmente de caulinita, o que não significa estágio pouco avançado de intemperismo. Ressalta-se, ainda o trabalho de Shinzato (1998) que afirma que a relação silte/argila não deve ser utilizada como indicadora de grau de intemperismo em solos cujo material de origem é sedimentar, ou seja, é resultado da deposição de detritos de outras rochas, assim como o calcário. 
Desta forma, os resultados encontrados foram semelhantes aos descritos por Shinzato (1998), Pereira et al. (2013) e Silva et al. (2013) em solos carbonáticos na região do Planalto Central Brasileiro.

De acordo com Embrapa (2013) a relação silte/argila é empregada em solos de textura franco arenosa ou mais fina e serve como base para avaliar o estágio de intemperismo presente em solos de regiões tropicais. Assim sendo, valores inferiores a 0,7 nos solos de textura média ou inferiores a 0,6 nos de textura argilosa ou muito argilosa são indicativos de intemperismo mais acentuado.

Ainda segundo Embrapa (2013) essa relação é mais comumente utilizada para diferenciar horizonte $\mathrm{B}$ latossólico de $\mathrm{B}$ incipiente, quando estes apresentam características morfológicas semelhantes.

\subsection{4 - Teores de $\mathrm{SiO}_{2}, \mathrm{Al}_{2} \mathrm{O}_{3}, \mathrm{Fe}_{2} \mathrm{O}_{3}$ e Índices $\mathrm{Ki}$ e $\mathrm{Kr}$}

Os resultados dos teores de $\mathrm{SiO}_{2}, \mathrm{Al}_{2} \mathrm{O}_{3}, \mathrm{Fe}_{2} \mathrm{O}_{3}$, obtidos pelo ataque sulfúrico e os resultados dos índices $\mathrm{Ki}$ e $\mathrm{Kr}$ da Geo-topossequências estudadas (Catingueiro, Pedreira e DF-205) estão apresentados nas tabelas 10, 11 e 12.

Tabela 10. Teores de $\mathrm{SiO}_{2}, \mathrm{Al}_{2} \mathrm{O}_{3}, \mathrm{Fe}_{2} \mathrm{O}_{3}$, índices $\mathrm{Ki}$ e $\mathrm{Kr}$ da Geo-topossequência Catingueiro.

\begin{tabular}{c|c|c|c|c|c}
\hline Horizonte & $\mathbf{S i O}_{\mathbf{2}}$ & $\mathbf{A l}_{2} \mathbf{O}_{\mathbf{3}}$ & $\mathbf{F e}_{\mathbf{2}} \mathbf{O}_{\mathbf{3}}$ & $\mathbf{K i}$ & $\mathbf{K r}$ \\
\hline \multicolumn{5}{c}{$\mathrm{g.kg}^{-1}$} & \\
\hline $\mathrm{Bt}$ Perfil I - NITOSSOLO HÁPLLICO Distrófico úmbrico - NXd & 153,0 & 103,5 & 57,3 & 2,51 & 6,09 \\
\hline \multicolumn{6}{c}{ Perfil II - ARGISSOLO VERMELHO Eutroférrico típico - PVef } \\
\hline $\mathrm{Bt}$ & 212,0 & 104,5 & 240,2 & 3,45 & 18,46 \\
\hline \multicolumn{7}{c}{ Perfil III - CHERNOSSOLO ARGILÚVICO Férrico típico - MTf } \\
\hline $\mathrm{Bi}$ & 260,9 & 151,4 & 245,2 & 3,02 & 18,35 \\
\hline Perfil IV - ARGISSOLO VERMELHO-AMARELO Distrófico típico - PVAd \\
\hline $\mathrm{Bt}$ & 235,0 & 170,8 & 44,0 & 2,34 & 5,09 \\
\hline
\end{tabular}


Tabela 11. Teores de $\mathrm{SiO}_{2}, \mathrm{Al}_{2} \mathrm{O}_{3}, \mathrm{Fe}_{2} \mathrm{O}_{3}$, índices $\mathrm{Ki}$ e $\mathrm{Kr}$ da Geo-topossequência Pedreira.

\begin{tabular}{c|c|c|c|c|c}
\hline Horizonte & $\mathbf{S i O}_{\mathbf{2}}$ & $\mathbf{A l}_{2} \mathbf{O}_{\mathbf{3}}$ & $\mathbf{F e}_{2} \mathbf{O}_{\mathbf{3}}$ & $\mathbf{K i}$ & $\mathbf{K r}$ \\
\hline \multicolumn{5}{c}{ g.kg } \\
\hline \multicolumn{5}{|c}{ Perfil I - NITOSSOLO HÁPLICO Distrófico típico - NXd } \\
\hline $\mathrm{Bt}$ (nítico) & 260,0 & 188,1 & 49,6 & 2,35 & 5,45 \\
\hline \multicolumn{7}{c}{ Perfil II - NITOSSOLO VERMELHO Eutrófico chernossólico - NVe } \\
\hline Bt(nítico) & 259,0 & 184,0 & 62,8 & 2,39 & 6,32 \\
\hline \multicolumn{7}{c}{ Perfil III - NITOSSOLO VERMELHO Eutrófico chernossólico - NVe } \\
\hline Bt(nítico) & 222,0 & 152,9 & 60,8 & 2,47 & 6,27 \\
\hline
\end{tabular}

Tabela 12. Teores de $\mathrm{SiO}_{2}, \mathrm{Al}_{2} \mathrm{O}_{3}, \mathrm{Fe}_{2} \mathrm{O}_{3}$, índices $\mathrm{Ki}$ e $\mathrm{Kr}$ da Geo-topossequência DF205.

\begin{tabular}{c|c|c|c|c|c}
\hline Horizonte & $\mathbf{S i O}_{\mathbf{2}}$ & $\mathbf{A l}_{2} \mathbf{O}_{\mathbf{3}}$ & $\mathbf{F e}_{2} \mathbf{O}_{\mathbf{3}}$ & $\mathbf{K i}$ & $\mathbf{K r}$ \\
\hline \multicolumn{6}{c}{ P.kg } \\
\hline \multicolumn{7}{c}{ Perfil I - CHERNOSSOLO HÁPLICO Férrico típico - MXf } \\
\hline $\mathrm{Bi}$ & 302,0 & 182,0 & 243,4 & 2,82 & 18,03 \\
\hline \multicolumn{6}{c}{ Perfil II - ARGISSOLO VERMELHO Eutroférrico típico - PVef } \\
\hline $\mathrm{Bt}$ & 272,0 & 149,9 & 269,5 & 3,08 & 19,93 \\
\hline \multicolumn{6}{c}{ Perfil III - NITOSSOLO VERMELHO Distroférrico típico - NVf } \\
\hline Bt(nítico) & 223,0 & 142,7 & 302,7 & 2,66 & 21,58 \\
\hline
\end{tabular}

A determinação de $\mathrm{SiO}_{2}$ nos solos tem interesse na compreensão de certos fenômenos pedogenéticos, uma vez que um dos principais aspectos do intemperismo químico nos trópicos úmidos é a remoção de sílica do perfil do solo (Raij e Camargo, 1973 e Korndörfer et al., 1999).

$\mathrm{O}$ teor de $\mathrm{SiO}_{2}$ variou entre $153,0 \mathrm{gkg}^{-1}$ a $260,9 \mathrm{gkg}^{-1}$, na Geo-topossequência Catingueiro, de $222,0 \mathrm{gkg}^{-1}$ a $260,0 \mathrm{gkg}^{-1}$ na Geo-topossequência Pedreira e de 223,0 $\mathrm{gkg}^{-1}$ a 302,0 $\mathrm{gkg}^{-1}$ na Geo-topossequência DF-205. Os teores de $\mathrm{SiO}_{2}$ dos solos estudados foram semelhantes aos valores encontrados por Pereira et al. (2012) e Silva et al. (2013).

O silício $(\mathrm{Si})$ depois do oxigênio $(\mathrm{O})$ é o elemento mais abundante na litosfera, representando 27,7\% da crosta terrestre (Malavolta, 1980; Exley, 1998). Está presente em minerais primários silicatados, como feldspato, augita, quartzo e mica, e secundários, como caulinita, montmorilonita, ilita e clorita, todos com resistência diferente ao intemperismo, que alcança seu ponto máximo no quartzo e mínimo nas olivinas e piroxênios (Malavolta, 1980; Raij, 1991; Exley, 1998). O grau de intemperismo mineral depende, também, de fatores ambientais como a temperatura, o 
pH e a composição iônica do solvente (lixiviação e características hidrológicas como o fluxo de água) (Exley, 1998).

Os teores totais de silício na fração argila diminuem conforme o grau de intemperismo, e são menores nos solos com horizonte B latossólico do que naqueles com horizonte B textural (Raij e Camargo, 1973).

A quantidade de $\mathrm{Al}_{2} \mathrm{O}_{3}$ demonstrou pouca variação entre os solos das três geotopossequências variando, no geral, de 103,5g. $\mathrm{kg}^{-1}$ a $188,1 \mathrm{~g} \cdot \mathrm{kg}^{-1}$ (Tabelas 10, 11 e 12). Pereira et al. (2012) e Silva et al. (2013) encontraram valores mais elevados de $\mathrm{Al}_{2} \mathrm{O}_{3}$ nos solos que apresentam horizonte B textural.

O alumínio está entre os mais importantes e mais comumente analisados constituintes em água, solo, sedimentos, material geológico, e tecido de plantas. Entre os minerais contendo significativas quantidades de alumínio estão os aluminossilicatos, incluindo os felsdspatos, micas, caulinitas, esmectitas e outros minerais filossilicatados. Alumínio também é um componente primário de outros minerais não silicatados que ocorrem nos solos e materiais geológicos, incluindo minerais como gibbsita, variscita, e Al sulfatados como alunita ou basaluminita (Bertsch et al., 1995).

O Al quimicamente ativo ou lábil pode apresentar-se sob diversas formas, as quais são controladas pelo pH e pela composição mineralógica do sistema. A dissolução dos minerais primários e secundários em solos ácidos libera o Al para a solução do solo, mas suas formas químicas e as respectivas concentrações em solução irão depender do $\mathrm{pH}$ do solo, da quantidade e do tipo dos minerais presentes que contêm Al, do equilíbrio com as superfícies de troca, bem como das reações de complexação com a MO (Lindsay e Walthall, 1996).

Segundo Resende e Santana (1998) e IBGE (2007) devido à pequena remoção do alumínio do solo, esse elemento é usado junto com o silício para avaliar o grau de evolução de materiais em decomposição, por meio da relação molecular sílica/alumina, cujo símbolo é Ki. Esse índice, representado pela relação $\left(\mathrm{SiO}_{2} / \mathrm{Al}_{2} \mathrm{O}_{3}\right)$, é utilizado para estabelecer um limite entre solos muito intemperizados $(\mathrm{Ki}<2,0)$ e pouco intemperizados $(\mathrm{Ki}>2,0)$, além de ser um referencial empregado na definição de horizonte B latossólico $(\mathrm{Ki}<2,2)$. Outra relação semelhante é o $\mathrm{Kr}$, que representa a relação entre um elemento de grande mobilidade $(\mathrm{Si})$ e o somatório de elementos de baixa mobilidade (Fe e $\mathrm{Al}$ ). Por envolver os teores de $\mathrm{Fe}, \mathrm{Al}$ e $\mathrm{Si}$, é empregado para separar solos cauliníticos $(\mathrm{Kr}>0,75)$ de solos oxídicos $(\mathrm{Kr}<0,75)$. 
A relação $\mathrm{SiO}_{2}$ e $\mathrm{Al}_{2} \mathrm{O}_{3}$ reflete a presença de argilominerais 2:1 e 1:1, que está relacionada ao estágio de evolução dos solos. Segundo Kampf et al. (2009) solos com maior proporção de minerais 2:1 (mica, esmectita e vermiculita, entre outros) são considerados menos intemperizados e, geralmente, apresentam maior capacidade de suprir nutrientes às plantas. Observando os resultados da relação $\mathrm{SiO}_{2} / \mathrm{Al}_{2} \mathrm{O}_{3}$ nos solos estudados é possível afirmar que esses solos sofreram lixiviação ou intemperização pouca intensa e, conseqüentemente, apresentam-se menos alterados, uma vez que apresentaram índice $\mathrm{Ki}>2,0 \mathrm{em}$ todos os perfis das três geo-topossequências, indicando a presença de argilominerais $2: 1$, reflexo do baixo grau de intemperização, com as reações de hidrólise limitadas.

De acordo com Neto et al. (2009) a relação Ki alta em solos jovens está relacionada ao menor grau de intemperismo destes solos, em função da sua posição de desenvolvimento na paisagem (relevo ondulado) que favorece a constante remoção dos materiais mais intemperizados da superfície e exposição dos materiais menos intemperizados da subsuperfície. Tal fato mantém maior permanência de silício no meio e conseqüentemente maiores valores de Ki.

Em todos os perfis analisados foram encontrados valores de $\mathrm{Kr}$ superiores a 0,75 permitindo indicar a presença de minerais do tipo 1:1, como a caulinita (Carvalho et al., 2013).

A ocorrência de argilominerais 2:1 e 1:1 foi comprovada por meio das análises de difratometria de raios-X.

Com relação aos teores de $\mathrm{Fe}_{2} \mathrm{O}_{3}$, os solos da Geo-topossequência Pedreira e os perfis I e IV da Geo-topossequência Catingueiro (Nitossolo Háplico Distrófico úmbrico e Argissolo Vermelho-Amarelo Distrófico típico, respectivamente) foram caracterizados como hipoférricos, pois apresentaram teor de $\mathrm{Fe}_{2} \mathrm{O}_{3}$ inferior a $80 \mathrm{gkg}^{-1}$ de solo. Os solos da Geo-topossequência DF-205 e os perfis II e III da Geo-topossequência Catingueiro (Argissolo Vermelho Eutroférrico típico e Chernossolo Argilúvico Férrico típico), entretanto, apresentaram elevados teores de $\mathrm{Fe}_{2} \mathrm{O}_{3}$, variando de 240,20 $\mathrm{gkg}^{-1}$ a 302,70 $\mathrm{gkg}^{-1}$ (Tabelas 10, 11 e 12) de solo, sendo caracterizados como férricos.

Os teores de $\mathrm{Fe}_{2} \mathrm{O}_{3}$ nos solos estão associados à natureza do material de origem (Lacerda et al., 2009; Barbosa et al., 2009; Costa, 2012). No presente estudo, os solos classificados como férricos foram originados a partir rochas psamopelíticas do Grupo Paranoá e filitos do Grupo Canastra, onde algumas litologias são enriquecidas em Fe. No DF, o Grupo Canastra é caracterizado por um conjunto amplamente dominado por 
filitos variados com contribuição restrita de quartzitos, calciofilitos, mármores finos e filitos carbonosos. A maior parte dos afloramentos é bastante intemperizada, mas nos raros locais onde a alteração é mais tênue pode-se observar que os filitos são bandados com níveis mais claros ricos em mica-branca, carbonato e quartzo e níveis mais escuros enriquecidos em clorita, aluminossilicato que possui Fe em sua composição. A unidade PC do Grupo Paranoá, por sua vez, é caracterizada pelas fáceis argilo-carbonatadas com metargilitos; ardósias, que possuem como mineralogia principal sericita, clorita e quartzo; metamargas; lentes de calcário e calcarenitos. Ocorrem raras lentes de dolomitos com estromatólitos. Na parte inferior da unidade, as lentes de calcário possuem bandamentos argilosos, lentes de quartzitos médios a microconglomeráticos que ocorrem comumente na base de toda a unidade (Freitas-Silva e Campos, 1998).

\subsection{5 - Mineralogia}

A análise mineralógica foi realizada com a fração argila da TFSA em amostras do horizonte $\mathrm{B}$ diagnóstico de cada perfil de solo avaliado, utilizando a técnica de Difratometria de Raios-X (DRX).

A composição mineralógica do solo é, entre vários aspectos, o que mais influencia grande parte dos fenômenos físicos e químicos que nele ocorrem. Do ponto de vista da gênese dos solos, a composição e as transformações mineralógicas dos seus materiais possibilitam melhor entendimento da evolução dos sistemas de intemperismo e pedogenêse, já que os minerais são indicadores da dimensão com que os diferentes processos pedogenéticos têm atuado nas paisagens atuais (Coelho e Vidal-Torrado, 2003).

Por meio da interpretação dos difratogramas (Figuras 10, 11, 12) foi possível observar a semelhança da mineralogia dos perfis das três geo-topossequências. No geral, foram identificados argilominerais 2:1, representados pela vermiculita (Ve) e illita (Ilit); argilomineral 1:1, representado pela caulinita $(\mathrm{Ct})$; óxidos de ferro, representados pela hematita $(\mathrm{Hm})$ e goethita $(\mathrm{Gt})$; hidróxido de alumínio, representado pela gibbisita (Gb) e óxido de titânio, representado pelo anatásio (An). 

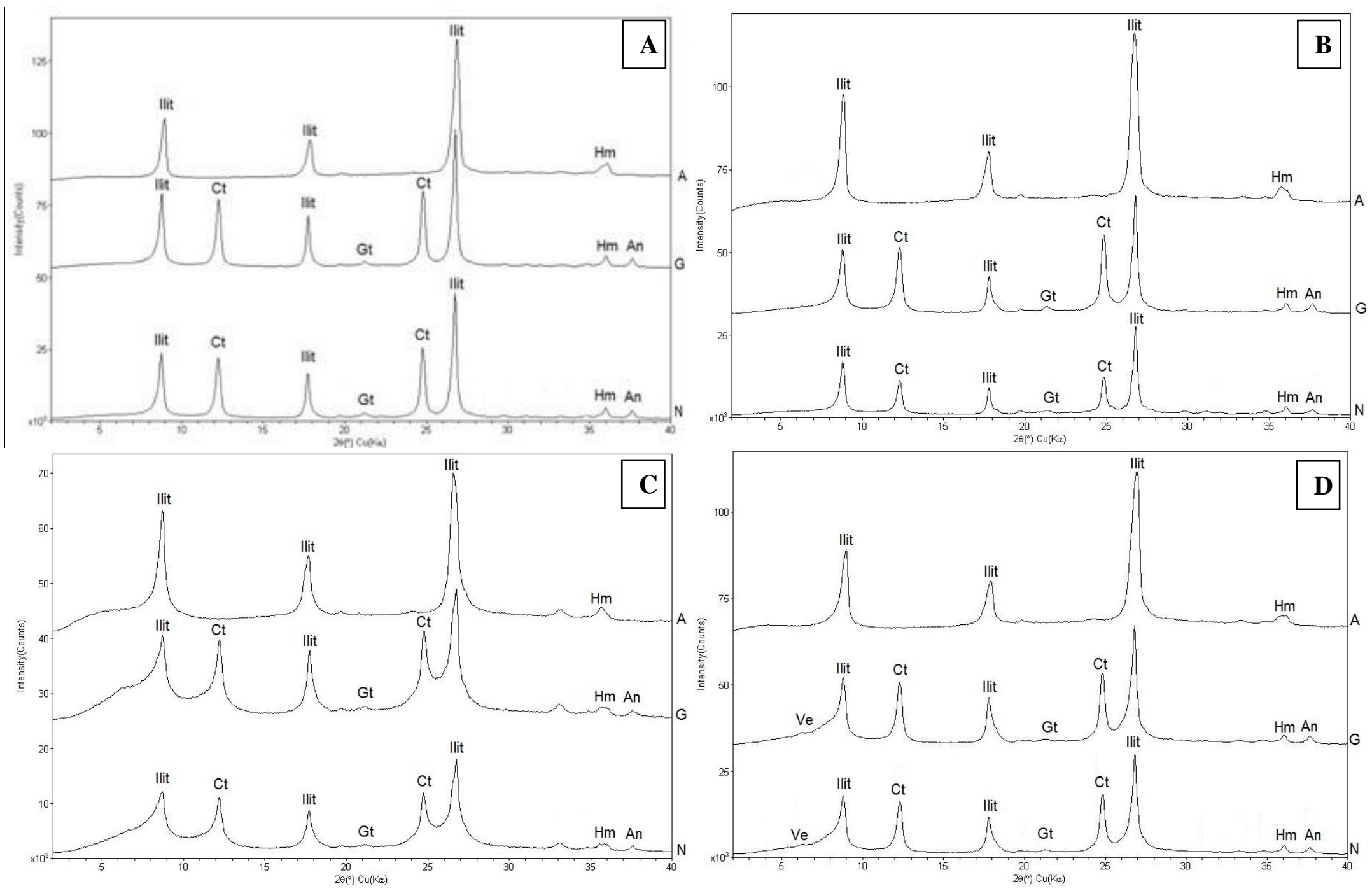

Figura 10. Difratogramas do horizonte B dos perfis da Geo-topossequência Catingueiro. A) NXd, B) PVef, C) MTf, D) PVAd. 

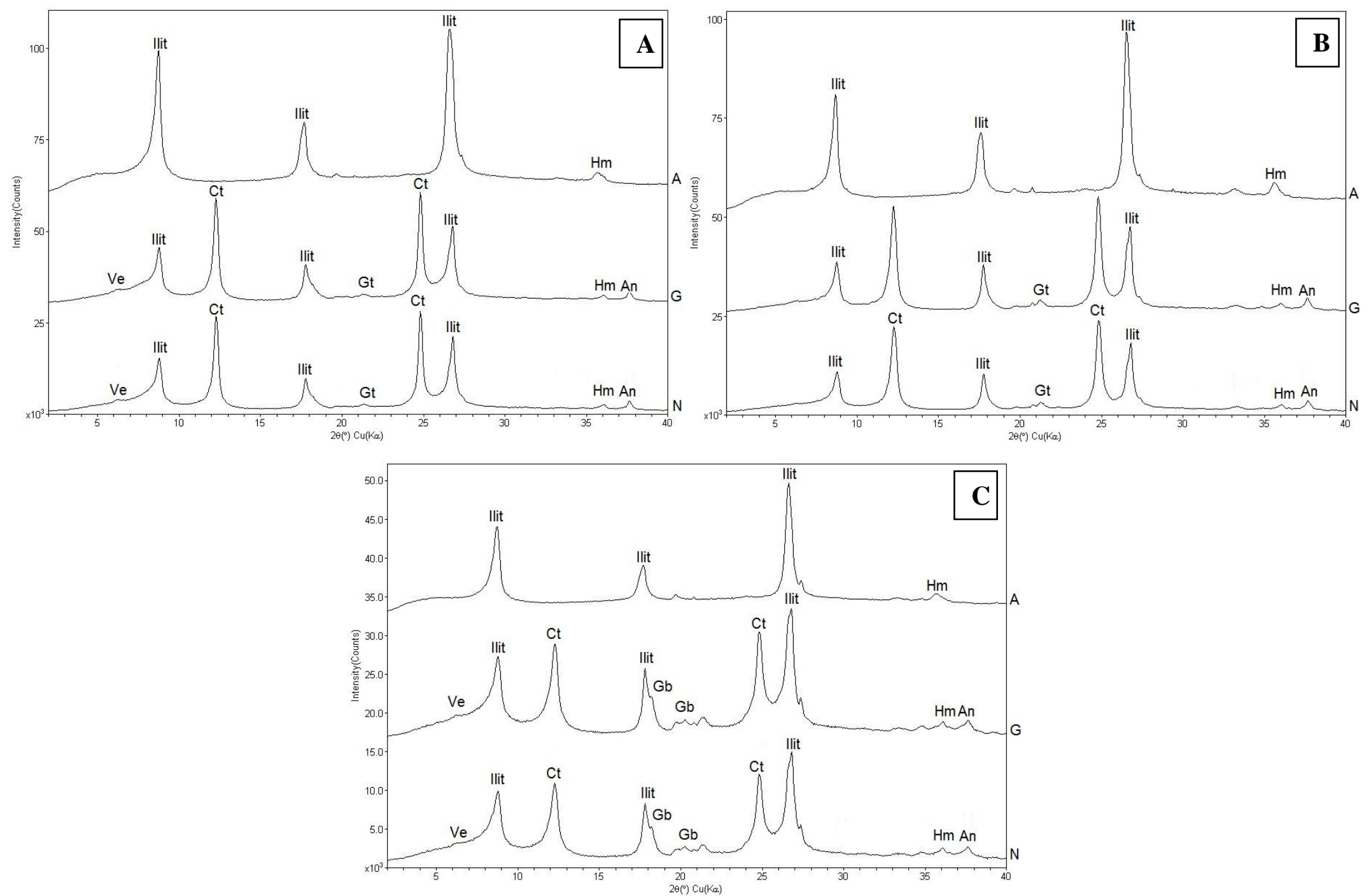

Figura 11. Difratogramas do horizonte B dos perfis da Geo-topossequência Pedreira. A) NXd, B) NVe, C) NVe. 

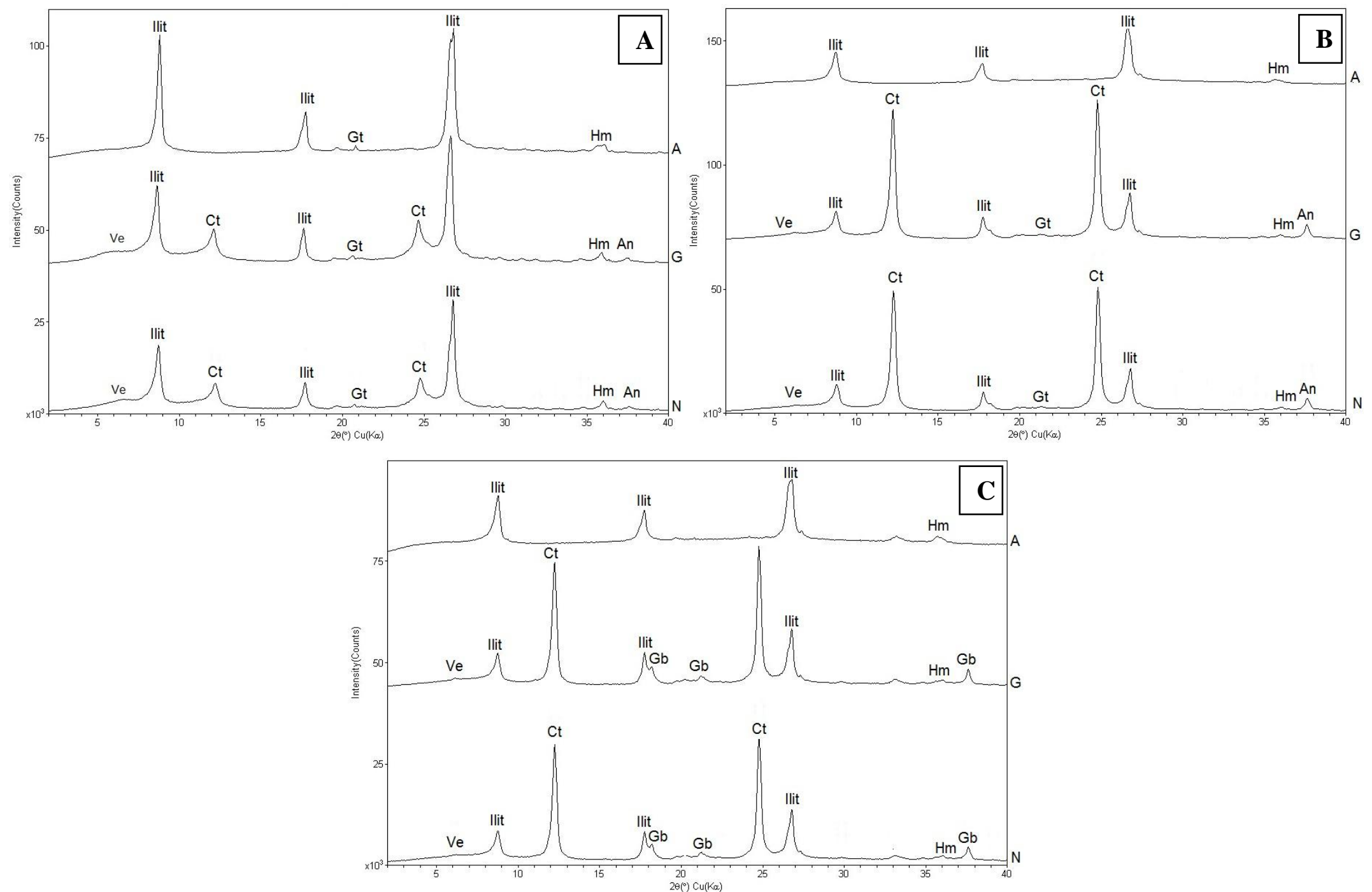

Figura 12. Difratogramas do horizonte B dos perfis da Geo-topossequência DF-205. A) MXf, B) PVef, C) NVf. 
Os argilominerais 2:1 são encontrados normalmente sob condições de baixa lixiviação e com alta concentração de bases e sílica solúvel na solução do solo. À medida que a concentração de bases decresce com a lixiviação e ocorre a hidrólise parcial, os minerais do grupo da caulinita são formados. Posteriormente ocorre a hidrólise total dando origem ao desenvolvimento da gibbsita. Nas reações intempéricas de oxidação originam-se os óxidos do solo, como a hematita, goethita e anatásio (Sherman, 1971; Van Shuylenborgh, 1971; Jackson, 1965, Fontes et al., 2001).

A presença de argilominerais 2:1 em todos os perfis indica o menor grau de evolução desses solos, que preservaram herança do material de origem. A vermiculita, que foi encontrada em grande parte dos solos estudados, é formada pela alteração da biotita, clorita e outros minerais carbonatados ricos em $\mathrm{Mg}, \mathrm{Ca}$ e $\mathrm{Fe}$, o que está diretamente relacionado com os elevados valores de soma de bases, saturação por bases e CTC dos solos. Picos relacionados à vermiculita também foram observados em solos distróficos (PVAd da Geo-topossequência Catingueiro, NXd da Geo-topossequência Pedreira e NVf da Geo-topossequência DF-205) (Figuras 10, 11 e 12); nestes casos correspondem à vermiculita com hidróxi nas entrecamadas. Esta vermiculita com hidróxi nas entrecamadas pode resultar da degradação da clorita ou da deposição de hidróxidos nas entrecamadas das argilas expansivas (Barnhisel, 1977). Esse argilomineral com hidróxidos interlamelares (cloritizados) são mais resistentes, persistindo nos solos mesmo em condições de intemperismo intenso, com efeito "antigibbsítico" retardando o processo intempérico, não permitindo que os solos atingissem estádios mais avançados de intemperismo (Jackson, 1965, Lacerda et al., 2001).

A ilita, por sua vez, é secundária da moscovita, sericita e feldspato potássico, minerais ricos em $\mathrm{K}$, onde tanto os minerais primários como a illita são resistentes ao intemperismo e, portanto, a liberação de K para a solução do solo é bem prejudicada. A ilita foi detectada em todos os perfis das três geo-topossequências. Segundo Kämpf et al. (2009) os minerais secundários são resultado da intemperização dos minerais primários, por transformações no estado sólido ou via reações de dissolução/neoformação e geralmente predominam na fração argila dos solos. Os minerais secundários do grupo dos filossilicatos, são mais estáveis que outros minerais silicatados potenciais fontes de nutrientes, tais como feldspatos, biotitas, anfibólios, piroxênios e olivinas, constituindo-se como as maiores fontes de $\mathrm{K}, \mathrm{Fe}$ e $\mathrm{Mg}$ em ambientes tropicais (Melo e Wypych, 2009). 
A maior parte dos solos dos trópicos úmidos tem sua fração argila dominada pela caulinita (Hughes e Brown, 1979). A alta frequência e estabilidade da caulinita nos solos se devem, via de regra, à possibilidade de sua formação a partir de muitos minerais filossiticatados (feldspatos, micas) principais constituintes da grande maioria das rochas, desde que haja remoção parcial da sílica associada a perdas de cátions básicos (Kämpf et al., 2012). Ainda segundo estes autores caulinitas podem apresentar alguns resquícios do mineral que a originou (mica) em proporção difícil de detecção por Difratometria de raios X (DRX). Pela análise dos difratogramas foi possível observar a grande participação desse mineral em todos os perfis estudados.

A gibbisita, por sua vez, representa quase que exclusivamente o único hidróxido de alumínio cristalino presente em solos das regiões tropicais e está diretamente associado à intensidade do intemperismo. Também pode ser encontrada em solos mais jovens devido à possibilidade de vir a ser um dos primeiros produtos formados a partir do intemperismo dos feldspatos (Fontes e Weeds, 1991; Mesquita Filho e Torrent, 1993, Alleoni, 1996, Netto, 1996).

No presente estudo a gibbisita foi encontrada apenas no perfil 3 (NVe) da Geotopossequência Pedreira e no perfil 3 (NVf) da Geo-topossequência DF-205 (Figuras 10,11 e 12). A presença desse mineral nesses perfis pode estar associada à maior evolução pedogenética dos Nitossolos em relação às demais classes de solos que apresentam horizonte B textural, tais como Argissolos e Chernossolos.

Os óxidos e hidróxidos de ferro aparecem principalmente sob a forma de goethita $(\mathrm{FeOOH})$, presente em quase todos os tipos de solos e regiões climáticas, respondendo pela coloração amarelada e amarronzada nos solos. A hematita $\left(\mathrm{Fe}_{2} \mathrm{O}_{3}\right)$, apesar de estar presente em menores quantidades que a goethita, apresenta alto poder pigmentante (Scheffer et al., 1958; Tremocoldi, 2003; Das e Hendry, 2011), cuja presença é reponsável pela a cor avermelhada dos solos Todavia, nos solos avaliados a relação $\mathrm{Hm} / \mathrm{Gt}$ foi maior, denotando maior ocorrência de hematita em relação à goethita.

Apesar da Difratometria de Raios-X ser uma análise de natureza qualitativa é possível relacionar os minerais semelhantes observando o tamanho dos picos de cada mineral. Assim foi possível estabelecer a relação $\mathrm{Hm} / \mathrm{Gt}$, onde houve predomínio da hematita. Na relação Ilit/Ct, predominou o argilomineral 2:1 na maioria dos perfis avaliados, com exceção do perfil I (NXd) e perfil II (NVe) da Geo-topossequência Pedreira e o perfil II (PVAe) e perfil III (NVf) da Geo-topossequêcia DF-205 (Figuras 
10, 11 e 12). Nas relações $\mathrm{Ct} / \mathrm{Gb}$ e $\mathrm{Ve} / \mathrm{Ct}$, a caulinita foi o mineral predominante. $\mathrm{Na}$ relação Ilit/Ve houve predomínio do mineral ilita.

\subsection{6 - Geoquímica}

A análise geoquímica foi realizada por meio de Fluorescência de Raios-X. Foram identificados elementos maiores (Tabelas 13, 15, 17) e elementos-traço nos horizontes B dos solos estudados (Tabelas 14, 16, 18).

Os teores de $\mathrm{SiO}_{2}$ e de $\mathrm{Al}_{2} \mathrm{O}_{3}$ encontram-se dentro da normalidade para as classes de solos estudadas (Tabelas 13, 15 e 17), refletindo a presença de argilominerais 2:1, denotando um estágio de dessilicatização limitada, com preservação de bases e sílica na mineralogia do solo. Esse comportamento está relacionado a solos jovens, que apresentam minerais e elementos herdados do material de origem, que são litologias pelítica-carbonatadas do Grupo Paranoá e Canastra (clorita carbonato filitos, fengita filitos, clorita filitos associados a mármores calcíticos e dolomíticos impuros - clorita mármores e lentes meta-calcárias).

Santos et al. (2010) estudando a gênese e classificação de solos numa topossequência no ambiente de Mar dos Morros do médio Vale do Paraíba do Sul, RJ, também verificou predominância do Si sobre os demais elementos em todos os perfis.

Os valores de $\mathrm{Fe}_{2} \mathrm{O}_{3}$ foram inferiores aos obtidos pelo ataque sulfúrico (Tabelas 13, 15 e 17), uma vez que se tratam de metodologias de análise geoquímica diferentes. Já o comportamento do $\mathrm{SiO}_{2}$ e $\mathrm{Al}_{2} \mathrm{O}_{3}$ apresentam o mesmo padrão definido pela metodologia de ataque sulfúrico (Tabelas 13, 15 e 17), tal como observado por Neto et al. (2009). Mesmo em solos com horizontes B texturais, devido à baixa mobilidade do $\mathrm{Fe}$ e $\mathrm{Ti}$, estes elementos apresentam incremento relativo neste horizonte, na forma de óxidos de Fe e Ti (Lacerda et al., 2002).

Em relação aos demais elementos maiores constituintes dos solos estudados foram verificados elevados teores de $\mathrm{K}_{2} \mathrm{O}$ em todos os solos das três geotopossequências, o que é corroborado pela ocorrência comum da ilita nos horizonte B destes solos (Tabelas 13, 15 e 17). Em contrapartida os teores de $\mathrm{CaO}$ e $\mathrm{MgO}$ foram inferiores (Tabelas 13, 15 e 17), porém, ainda com valores intermediários para solos, uma vez no processo intempérico, o $\mathrm{Ca}$ e o $\mathrm{Mg}$ apresentam alta mobilidade e processos de lixiviação mais pronunciados do que o K, onde a ordem de perda desses constituintes ao longo de sequências de alteração pedogenética foi estabelecida em $\mathrm{Ca}>\mathrm{Na}>\mathrm{Mg}>$ 
$\mathrm{K}>\mathrm{Si}>\mathrm{Fe}>\mathrm{Al}$ (Loughnan, 1969; Lacerda et al., 2002). A ocorrência destes elementos mostram a herança dos materiais de origem destes solos, ou seja, rochas carbonatadas, mármores e lentes de meta-calcários dos Grupos Paranoá e Canastra.

Os menores valores encontrados nos óxidos constituintes dos solos avaliados foram os de $\mathrm{Na}_{2} \mathrm{O}$ (Tabelas 13, 15 e 17).

Os teores de $\mathrm{P}_{2} \mathrm{O}_{5}$ obtidos para todos os solos estudados (Tabelas 13, 15 e 17) são considerados médios a altos em horizontes Bt de solos. Sua origem pode ser a ocorrência de fosfatos tricálcios de origem sedimentar, geralmente associado a carbonatos de cálcio e magnésio (Souza, 2001). Semelhante ao trabalho de Santos et al. (2010) os teores de $\mathrm{MnO}$ apresentaram-se relativamente baixos (Tabelas 13, 15 e 17), refletindo a presença reduzida desse elemento na constituição do material de origem. Entretanto, os teores de $\mathrm{TiO}_{2}$ são moderados (Tabelas 13, 15 e 17), superiores aos descritos por Santos et al. (2010). O Ti é um elemento que tem grande afinidade geoquímica com o Fe, podendo formar óxidos de $\mathrm{Fe}$ e Ti, que apresentam concentração relativa nos horizontes $\mathrm{B}$ de solos, dado a baixa mobilidade destes elementos (Lacerda, 2002). A presença de $\mathrm{TiO}_{2}$ nos solos, também foi constatada pela ocorrência do mineral anatásio.

Segundo Luz et al. (1992); Rolim Neto e Santos (1994); Moreira e Oliveira, 2008) os elementos Zr e Ti integram minerais de grande estabilidade, como o zircão $\left(\mathrm{ZrSiO}_{4}\right)$ e o rutilo $\left(\mathrm{TiO}_{2}\right)$, respectivamente. Por isso, eles têm sido utilizados como indicadores da quantidade de material de origem que foi intemperizado para produzir determinado volume de solo, bem como para indicar a ocorrência de descontinuidade litológica no perfil.

A ocorrência natural de elementos-traço em solos depende, principalmente, do material de origem sobre o qual o solo se formou, dos processos de formação, da composição e proporção dos componentes de sua fase sólida. A relação do solo com o material de origem é bastante evidenciada quando o primeiro é formado "in situ" sobre a rocha, tornando-se menos expressiva nos solos originados sobre materiais previamente intemperizados, tal como as rochas sedimentares. Solos com origem em rochas básicas, naturalmente mais ricas em metais, apresentam maiores teores desses elementos, quando comparados com aqueles formados sobre granitos, gnaisses, arenitos e siltitos (Valadares, 1975; Rovers et al., 1983; Tiller, 1989; Oliveira, 1996, Fadigas et al., 2006). 
Tabela 13. Análise geoquímica dos óxidos constituintes da Geo-topossequência Catingueiro.

\begin{tabular}{|c|c|c|c|c|c|c|c|c|c|c|}
\hline Horizonte & $\mathrm{SiO}_{2}$ & $\mathbf{A l}_{2} \mathbf{O}_{3}$ & MgO & $\mathrm{Fe}_{2} \mathrm{O}_{3}$ & $\mathrm{CaO}$ & $\mathrm{Na}_{2} \mathrm{O}$ & $\mathbf{K}_{2} \mathbf{O}$ & $\mathrm{TiO}_{2}$ & $\mathbf{P}_{2} \mathbf{O}_{5}$ & MnO \\
\hline & \multicolumn{10}{|c|}{$\mathbf{g k g}^{-1}$} \\
\hline \multicolumn{11}{|c|}{ Perfil I - NITOSSOLO HÁPLICO Distrófico úmbrico - NXd } \\
\hline Bt (nítico) & 595,6 & 214,3 & 22,9 & 84,2 & 0,2 & 0,3 & 65,7 & 9,7 & 1,1 & 4,3 \\
\hline \multicolumn{11}{|c|}{ Perfil II - ARGISSOLO VERMELHO Eutroférrico típico - PVef } \\
\hline $\mathrm{Bt}$ & 591,2 & 218,8 & 20,4 & 100,2 & 1,0 & 0,3 & 54,0 & 10,5 & 0,8 & 1,1 \\
\hline \multicolumn{11}{|c|}{ Perfil III - CHERNOSSOLO ARGILÚVICO Férrico típico - MTf } \\
\hline $\mathrm{Bi}$ & 556,1 & 213,4 & 21,3 & 142,1 & 5,2 & 0,2 & 43,2 & 10,6 & 1,0 & 5,3 \\
\hline \multicolumn{11}{|c|}{ Perfil IV - ARGISSOLO VERMELHO-AMARELO Distrófico típico - PVAd } \\
\hline $\mathrm{Bt}$ & 526,5 & 243,3 & 22,4 & 122,7 & 0,5 & 0,2 & 69,7 & 11,7 & 0,7 & 0,4 \\
\hline
\end{tabular}

Tabela 14. Análise geoquímica dos elementos-traço da Geo-topossequência Catingueiro.

\begin{tabular}{|c|c|c|c|c|c|c|c|c|c|c|c|c|}
\hline Horizonte & $\mathrm{Sr}$ & $\mathbf{R b}$ & $\mathbf{N i}$ & $\mathbf{C u}$ & $\mathbf{Z n}$ & $\mathbf{Z r}$ & $\mathbf{C r}$ & $\mathbf{V}$ & Co & Mo & $\mathbf{N b}$ & $\mathbf{P b}$ \\
\hline & \multicolumn{12}{|c|}{ mgkg $^{-1}$} \\
\hline \multicolumn{13}{|c|}{ Perfil I - NITOSSOLO HÁPLICO Distrófico úmbrico - NXd } \\
\hline Bt (nítico) & 10,00 & 270,00 & 50,00 & 70,00 & 90,00 & 500,00 & 90,00 & 70,00 & 20,00 & 0,00 & 20,00 & 60,00 \\
\hline \multicolumn{13}{|c|}{ Perfil II - ARGISSOLO VERMELHO Eutroférrico típico - PVef } \\
\hline $\mathrm{Bt}$ & 20,00 & 240,00 & 80,00 & 90,00 & 70,00 & 600,00 & 120,00 & 90,00 & 10,00 & 0,00 & 20,00 & 10,00 \\
\hline \multicolumn{13}{|c|}{ Perfil III - CHERNOSSOLO ARGILÚVICO Férrico típico - MTf } \\
\hline $\mathrm{Bi}$ & 30,00 & 330,00 & 110,00 & 90,00 & 70,00 & 370,00 & 140,00 & 80,00 & 30,00 & 0,00 & 30,00 & 0,00 \\
\hline \multicolumn{13}{|c|}{ Perfil IV - ARGISSOLO VERMELHO-AMARELO Distrófico típico - PVAd } \\
\hline $\mathrm{Bt}$ & 30,00 & 360,00 & 100,00 & 60,00 & 120,00 & 490,00 & 140,00 & 120,00 & 20,00 & 0,00 & 30,00 & 50,00 \\
\hline
\end{tabular}


Tabela 15. Análise geoquímica dos óxidos constituintes da Geo-topossequência Pedreira.

\begin{tabular}{|c|c|c|c|c|c|c|c|c|c|c|}
\hline Horizonte & $\mathrm{SiO}_{2}$ & $\mathbf{A l}_{2} \mathbf{O}_{3}$ & MgO & $\mathrm{Fe}_{2} \mathrm{O}_{3}$ & $\mathrm{CaO}$ & $\mathrm{Na}_{2} \mathrm{O}$ & $\mathbf{K}_{2} \mathbf{O}$ & $\mathrm{TiO}_{2}$ & $\mathbf{P}_{2} \mathbf{O}_{5}$ & $\mathrm{MnO}$ \\
\hline & \multicolumn{10}{|c|}{$\mathbf{g k g}^{-1}$} \\
\hline \multicolumn{11}{|c|}{ Perfil I - NITOSSOLO HÁPLICO Distrófico típico - NXd } \\
\hline Bt (nítico) & 563,5 & 251,5 & 16,0 & 105,4 & 0,9 & 0,2 & 47,1 & 12,4 & 0,8 & 0,2 \\
\hline \multicolumn{11}{|c|}{ Perfil II - NITOSSOLO VERMELHO Eutrófico chernossólico - NVe } \\
\hline Bt (nítico) & 557,3 & 245,0 & 16,2 & 115,0 & 0,3 & 0,2 & 46,2 & 17,0 & 0,5 & 0,4 \\
\hline \multicolumn{11}{|c|}{ Perfil III - NITOSSOLO VERMELHO Eutrófico chernossólico - NVe } \\
\hline Bt (nítico) & 542,6 & 245,9 & 14,5 & 138,4 & 0,8 & 0,2 & 36,0 & 13,6 & 4,7 & 1,3 \\
\hline
\end{tabular}

Tabela 16. Análise geoquímica dos elementos-traço da Geo-topossequência Pedreira.

\begin{tabular}{|c|c|c|c|c|c|c|c|c|c|c|c|c|}
\hline Horizonte & $\mathrm{Sr}$ & $\mathbf{R b}$ & $\mathbf{N i}$ & $\mathbf{C u}$ & Zn & $\mathbf{Z r}$ & $\mathbf{C r}$ & $\mathbf{V}$ & Co & Mo & $\mathbf{N b}$ & $\mathbf{P b}$ \\
\hline & \multicolumn{12}{|c|}{ mgkg $^{-1}$} \\
\hline \multicolumn{13}{|c|}{ Perfil I - NITOSSOLO HÁPLICO Distrófico típico - NXd } \\
\hline Bt (nítico) & 30,00 & 310,00 & 90,00 & 80,00 & 80,00 & 530,00 & 120,00 & 120,00 & 10,00 & 0,00 & 30,00 & 70,00 \\
\hline \multicolumn{13}{|c|}{ Perfil II - NITOSSOLO VERMELHO Eutrófico chernossólico - NVe } \\
\hline Bt (nítico) & 20,00 & 400,00 & 100,00 & 60,00 & 60,00 & 600,00 & 120,00 & 100,00 & 20,00 & 0,00 & 30,00 & 40,00 \\
\hline \multicolumn{13}{|c|}{ Perfil III - NITOSSOLO VERMELHO Eutrófico chernossólico - NVe } \\
\hline Bt (nítico) & 280,00 & 180,00 & 40,00 & 80,00 & 70,00 & 500,00 & 150,00 & 140,00 & 20,00 & 0,00 & 30,00 & 200,00 \\
\hline
\end{tabular}


Tabela 17. Análise geoquímica dos óxidos constituintes da Geo-topossequência DF-205.

\begin{tabular}{|c|c|c|c|c|c|c|c|c|c|c|}
\hline Horizonte & $\mathrm{SiO}_{2}$ & $\mathrm{Al}_{2} \mathbf{O}_{3}$ & MgO & $\mathrm{Fe}_{2} \mathrm{O}_{3}$ & $\mathrm{CaO}$ & $\mathrm{Na}_{2} \mathrm{O}$ & $\mathbf{K}_{2} \mathbf{O}$ & $\mathrm{TiO}_{2}$ & $\mathbf{P}_{2} \mathbf{O}_{5}$ & MnO \\
\hline & \multicolumn{10}{|c|}{$\mathbf{g k g}^{-1}$} \\
\hline \multicolumn{11}{|c|}{ Perfil I - CHERNOSSOLO HÁPLICO Férrico típico } \\
\hline $\mathrm{Bi}$ & 650,3 & 182,3 & 16,4 & 76,9 & 4,5 & 0,9 & 50,1 & 13,9 & 1,0 & 1,6 \\
\hline \multicolumn{11}{|c|}{ Perfil II - ARGISSOLO VERMELHO Eutroférrico típico - PVef } \\
\hline $\mathrm{Bt}$ & 607,2 & 267,0 & 12,9 & 56,0 & 1,4 & 0,2 & 35,8 & 15,5 & 2,1 & 0,2 \\
\hline \multicolumn{11}{|c|}{ Perfil III - NITOSSOLO VERMELHO Distroférrico típico - NVf } \\
\hline Bt (nítico) & 525,9 & 247,6 & 21,6 & 120,8 & 0,5 & 0,2 & 68,6 & 11,7 & 0,7 & 0,4 \\
\hline
\end{tabular}

Tabela 18. Análise geoquímica dos elementos-traço da Geo-topossequência DF-205.

\begin{tabular}{|c|c|c|c|c|c|c|c|c|c|c|c|c|}
\hline Horizonte & $\mathbf{S r}$ & $\mathbf{R b}$ & $\mathbf{N i}$ & $\mathbf{C u}$ & Zn & $\mathbf{Z r}$ & $\mathbf{C r}$ & $\mathbf{V}$ & Co & Mo & $\mathbf{N b}$ & $\mathbf{P b}$ \\
\hline & \multicolumn{12}{|c|}{$\mathrm{mgkg}^{-1}$} \\
\hline \multicolumn{13}{|c|}{ Perfil I - CHERNOSSOLO HÁPLICO Férrico típico } \\
\hline $\mathrm{Bi}$ & 70,00 & 240,00 & 90,00 & 50,00 & 110,00 & 830,00 & 150,00 & 80,00 & 30,00 & 0,00 & 30,00 & 40,00 \\
\hline \multicolumn{13}{|c|}{ Perfil II - ARGISSOLO VERMELHO Eutroférrico típico - PVef } \\
\hline $\mathrm{Bt}$ & 120,00 & 180,00 & 90,00 & 110,00 & 90,00 & 550,00 & 160,00 & 110,00 & 10,00 & 0,00 & 30,00 & 100,00 \\
\hline \multicolumn{13}{|c|}{ Perfil III - NITOSSOLO VERMELHO Distroférrico típico - NVf } \\
\hline $\mathrm{Bt}$ & 30,00 & 350,00 & 90,00 & 80,00 & 130,00 & 470,00 & 140,00 & 130,00 & 20,00 & 0,00 & 30,00 & 60,00 \\
\hline
\end{tabular}


O comportamento dos elementos-traço depende de sua forma química ou iônica, a qual é influenciada pelo $\mathrm{pH}$, quantidade presente, solubilidade, origem, se é pedogenética ou antropogênica. Adicionalmente, a disponibilidade destes elementostraço pode ser afetada pelas reações mediadas biologicamente e reações de oxi-redução sequenciais ocorrendo no solo (Slagle, 2000).

Outro fator decisivo na dinâmica dos elementos-traço é a capacidade de troca catiônica (CTC) do solo. A CTC está intimamente ligada às concentrações dos íons trocáveis presentes na solução do solo e nos sítios de troca nas interfaces coloidais do sistema (Raij, 1969; Sodré et al., 2001). Uma elevada CTC proporciona uma maior retenção dos elementos-traço no solo. A matéria orgânica, embora represente em média 5\% dos componentes sólidos, é responsável por cerca de 30\% a 65\% da CTC dos solos minerais, e mais de 50\% da CTC de solos arenosos e orgânicos (Matos et al., 1996).

O elemento-traço mais expressivo nos solos estudados foi o $\mathrm{Zr}$ (Tabelas 14, $16 \mathrm{e}$ 18). De acordo com Santos et al. (2010) o acúmulo de $\mathrm{Zr}$ é resultado da maior resistência dos minerais que apresentam esse elemento em sua composição, sendo, portanto, seu acúmulo relativo à medida que outros elementos são removidos do solo. $\mathrm{O}$ elemento $\mathrm{Nb}$ apresenta afinidade geoquímica com o $\mathrm{Zr}$ e normalmente encontra-se associado a este, particularmente constituindo o mineral zircão $\left(\mathrm{ZrSiO}_{4}\right)$, que pode ocorrer nos materiais originais dos solos avaliados, particularmente como mineral primário acessório da fração areia nas rochas sedimentares detríticas (Lacerda et al., 2002)

Os teores de $\mathrm{Ni}, \mathrm{Cu}, \mathrm{Zn}, \mathrm{Cr}, \mathrm{V}$, Co e Pb são considerados altos em todos os solos estudados (Tabelas 14, 16 e 18), visto que estes elementos geralmente mostram incremento em seus teores absolutos nos horizontes Bt. Estes elementos, de modo geral, conforme discutido por Hawes e Webb (1962), apresentam mobilidade variável nos solos; no entanto, esta é limitada pela co-precipitação com sesquióxidos de ferro. Precipitam-se nos solos, então, como elementos menores nos sesquióxidos de Fe, Ti e Mn e alguns deles, em especial o $\mathrm{Ni}$ e $\mathrm{Zn}$, em estruturas de argilominerais silicatados. Assim, fundamenta-se o comportamento geoquímico nos solos avaliados, com enriquecimento relativo desses elementos nos horizontes $\mathrm{Bt}$, acompanhando a concentração de sesquióxidos de ferro nesses horizontes, constatada por Lacerda et al. (2002) em estudos pedogeoquímicos em solos com horizonte B textural. Desta forma, esse enriquecimento relativo no horizonte Bt é mais notório nos solos MXf e NVf da Geo-topossequência DF 205 (Tabela 18), por apresentarem maior concentração de 
sesquióxidos de Fe nos horizontes Bt. Estes elementos ocorrem nos materiais de origem destes solos em minerais ferromagnesianos ou como sulfetos e óxidos primários.

Nos solos analisados o teor de Mo foi nulo (Tabelas 14, 16 e 18), sendo que esse comportamento pode ser explicado pela disponibilidade do Mo influenciada pelo $\mathrm{pH}$, assim como os demais elementos-traço. Nos solos estudados o pH variou entre fortemente ácido a moderadamente ácido, o que pode ter impedido a detecção do Mo, que é identificado em faixas de pH mais elevado (Camargo, 2006). Outra possibilidade é a ausência deste elemento nos materiais parentais, uma vez que o Mo ocorre preferencialmente como mineral primário acessório em rochas graníticas tais como molibdenita, sulfetos (molibdenita), molibdatos, fosfatos e silicatos, segundo Hawes e Webb (1962).

Os elementos $\mathrm{Sr}$ e $\mathrm{Rb}$ são considerados os elementos com maior mobilidade em relação aos demais elementos-traço avaliados, segundo Lacerda et al. (2002); desta forma apresentaram valores moderados nos solos estudados (Tabelas 14, 16 e 18). De modo geral, associam-se aos minerais potássicos (Lacerda et al., 2002), sendo, portanto, nos solos em pauta provavelmente associados à illita.

Os teores de $\mathrm{Ni}, \mathrm{Cu}$ e $\mathrm{Zn}$ indicam homogeneidade na composição do material de origem, representado por rochas psamo-pelito-carbonatadas.

Solos mais jovens e formados in situ, assim como Chernossolos, Argissolos e Nitossolos apresentam, em geral, teores mais elevados de elementos-traço que solos submetidos ao intenso intemperismo tropical e a um longo período de desenvolvimento, com ciclos de erosão e deposição. Efeitos diretos de remoção pelas plantas, lixiviação, escoamento superficial e erosão são os possíveis caminhos da redistribuição de elementos-traço no ambiente (Resende et al., 2007).

\section{4 - CONCLUSÕES}

1. Morfologicamente os solos estudados com horizonte B textural e B nítico da microbacia do Ribeirão Salinas (DF) são semelhantes. As diferenças verificadas foram a cor, fortemente influenciada pela natureza do material de origem, pela matéria orgânica e pela concentração de óxidos de Fe, além da diferenciação nos atributos morfológicos proporcionada pela variação no grau evolutivo dos solos. 
2. Na microbacia do Ribeirão Salinas, a variação nos atributos químicos das classes de solos estudadas, tal como na caracterização morfológica, é condicionada pelo grau de evolução e da herança da composição geoquímica e mineralógica dos respectivos materiais de origem.

3. Os Argissolos, Nitossolos e Chernossolos da área estudada apresentaram elevados índices $\mathrm{Ki}$ e $\mathrm{Kr}$, o que reflete a presença de argilominerais 2:1 e 1:1, compatível com a menor evolução pedogenética desses solos.

4. A relação silte/argila não foi um bom parâmetro físico para avaliar a maturidade genética dos solos estudados, uma vez que estes foram originados a partir de rochas sedimentares pré-intemperizadas.

5. A análise de difratometria de raios-X permitiu avaliar a composição mineralógica da fração argila dos solos estudados, demonstrando predomínio de mesmos ilita e caulinita, com destaque à ocorrência de vermiculita, argilomineral que favorece as condições de fertilidade natural dos solos.

6. O comportamento geoquímico dos solos avaliados foi semelhante, com presença de bases e sílica, óxidos de $\mathrm{Fe}, \mathrm{Al}$ e Ti, além de alguns elementos-traço, considerados micronutrientes dos solos.

7. O relevo fortemente dissecado e o substrato geológico proporcionaram a formação de solos com horizonte B textural e B nítico, tais como Chernossolos e Nitossolos, considerados de ocorrência incomum na região do Planalto Central do Brasil.

\section{5 - REFERÊNCIAS BIBLIOGRÁFICAS}

ALLEONI, L.R.F. Adsorção de boro em podzólico e latossolos paulistas. 1996. 127p.

Tese (Doutorado). Escola Superior de Agricultura "Luiz de Queiroz", Universidade de São Paulo, Piracicaba. 1996.

ANDRADE, H.; SCHAEFER, C. E. G. R.; DEMATTÊ, J. L. I.; ANDRADE, F. V. Pedogeomorfologia e Micropedologia de uma sequência Latossolo-Areia Quartzosa hidromórfica sobre rochas cristalinas do Estado do Amazonas. Geonomos, v.5, p.55-66. 1997. 
BARBOSA, I. O.; LACERDA, M. P. C.; BILICH, M. R. Relações pedomorfogeológicas nas Chapadas Elevadas do Distrito Federal. Revista Brasileira de Ciência do Solo, v.33, n.5, p.1373-1383, 2009.

BARNHISEL, R.I. Chlorites and hydroxyl interlayered vermiculite ad smectite. In: DIXON, J.B.; WEED, S.B., eds. Minerals in soil environments. Madison, Soil Science Society of America, p.331-356, 1977.

BERTSCH, P. M.; PARKER, D. R. Aqueous polynuclear aluminum species. In: SPOSITO, G. (Coord.). The environmental chemistry of aluminum. Boca Raton : CRC Press, p.117-168, 1995.

BESOAIN, E. Mineralogía de arcillas de suellos. San José, Costa Rica: IICA, 1985, 1216p.

CAMARGO, O. A. Reações e interações de micronutrientes no solo. 2006. Artigo em Hypertexto. Disponível em: <http://www.infobibos.com/Artigos/2006 3/micronutrientes/Index.htm>. Acesso em: 22/01/2015.

CAMPOS, R. C.; DEMATTÊ, J. A. M. Cor do solo: uma abordagem da forma convencional de obtenção em oposição à automatização do método para fins de classificação de solos. Revista Brasileira de Ciência do Solo, v.28, p.853-863, 2004.

CARVAlHO, S. A.; LIMA, J. M.; CURI, N.; SIlVA, C. A. TOLEDO, J. P. V. F.; SOARES, F. V. Coeficiente de distribuição do inseticida tiametoxam na fração mineral de solos sob efeito de ácidos orgânicos mono, di e tricarboxílicos. Química Nova, v.36, n.9, p.1323-1331, 2013.

CODEPLAN. Companhia de Planejamento do Distrito Federal. Atlas do Distrito Federal. Brasília, CODEPLAN, 1984.

CODEPLAN. Companhia de Planejamento do Distrito Federal. GeoServiço. 2009.

Disponível em: 〈http://ortofoto.mapa.codeplan.df.gov.br/demo/tms $>$. Acesso em: 02/02/2015.

COELHO, M. R.; VIDAL-TORRADO, P. Caracterização e gênese de perfis plínticos desenvolvidos de arenito do Grupo Bauru. II - Mineralogia. Revista Brasileira de Ciência do Solo, n.27, p.495-507, 2003.

COSTA, E. U. C. Caracterização e gênese de Argissolos e Nitossolos na Bacia Cabo, Pernambuco. 2012. 117p. Dissertação (Mestrado). Departamento de Agronomia, Universidade Federal Rural de Pernambuco, Recife. 2012. 
DAS, S., HENDRY, M.J. Changes of crystal morphology of aged goethite over a range of $\mathrm{pH}(2-13)$ at $100^{\circ} \mathrm{C}$. Applied Clay Science, n.51, p.192-197, 2011.

EMBRAPA - Empresa Brasileira de Pesquisa Agropecuária - Serviço Nacional de Levantamento e Conservação de solos. Boletim Técnico $n^{\circ} 53$. Levantamento de Reconhecimento dos solos do Distrito Federal, Rio de Janeiro, Embrapa, 1978. 466p.

EMBRAPA - Empresa Brasileira de Pesquisa Agropecuária. Centro Nacional de Pesquisas de Solos. Manual de Métodos de análise de solos. 2. ed. Rio de Janeiro, Embrapa, 1997. 212 p.

EMBRAPA - Empresa Brasileira de Pesquisa Agropecuária. Centro Nacional de Pesquisas de Solos. Sistema Brasileiro de Classificação de Solos. 3. ed. Brasília, DF, Embrapa Produção de Informação, 2013. 412 p.

ENZWEILER, J. Espectrometria de Fluorescência de Raios-X. UNICAMP - IGE, 2010. Disponível em:<http://www.ige.unicamp.br/site/aulas/9/FRX-texto.pdf $>$. Acesso em 20/01/2015.

EXLEY, C. Silicon in life: a bioinorganic solution to bioorganic essentiality. Journal of Inorganic Biochemistry, New York, v.69, n.3, p.139-144, Feb. 1998.

FADIGAS, F. de S.; AMARAL SOBRINHO, N. M. B.; MAZUR, N.; ANJOS, L. H. C.; FREIXO, A. A. Proposição de valores de referência para a concentração natural de metais pesados em solos brasileiros. Revista Brasileira de Engenharia Agrícola e Ambiental, v.10, n.3, p.699-705, 2006.

FERNANDEZ, R.N.; SCHULZE, D.G. Munsell colors of soils simulated by mixtures of goethite and hematite with kaolinite. Zeitschriftfür Pflanzenernährungund Bodenkunde, v.155, p.473-478, 1992.

FIGUEIREDO, M. A.; VARAJÃO, A. F. D. C.; FABRIS, J. D.; LOUTFI, I. S.; CARVALHO, A. P. Alteração superficial e pedomorfogeologia no sul do Complexo Bação - Quadrilátero Ferrífero (MG). Revista Brasileira de Ciência do Solo, v.28, p.713-729, 2004.

FIGUEIREDO, C. C.; RAMOS, M. L. G.; TOSTES, R. Propriedades físicas e matéria orgânica de um Latossolo Vermelho sob sistemas de manejo e cerrado nativo. Bioscience Journal, Uberlândia, v.24, n.3, p.24-30, 2008.

FONTES, M.P.F.; WEEDS, S. B. Iron oxides in selected Brazilian Oxisols: I. Mineralogy. Soil Science Society of America Journal, v.55, n.4, p.1143-1149, 1991. 
FREITAS-SILVA, F. H.; CAMPOS, J. E. G. Geologia do Distrito Federal. In: CAMPOS, J. E. G.; FREITAS-SILVA, F. H., coords. Inventário hidrogeológico e dos recursos hídricos superficiais do Distrito Federal. Brasília, SEMATECIEMA-MMA-SRH, 1998. CD-ROM.

GUARIZ, H. R. Variação da umidade e da densidade do solo sob diferentes coberturas vegetais. Revista Brasileira de Agroecologia, v.4, n.2, p.3293-3296, 2009.

HAWES, H.E.; WEBB, J.S. Geochemistry in Mineral Exploration. New York, Elsevier, 1962. $377 \mathrm{p}$

HUGHES, J. C.; BROWN, G. A. A cristallinity index for soil kaolins and its relation to parent rock, climate and soil maturity. Journal of Soil Science, v.30, n.3, p-557$563,1979$.

HUGUES, R. E.; MOORE, D. M.; GLASS, H. D. Qualitative and quantitative analysis of clay minerals in soil. Science Society of America, Madison, wis, p.330-359, 1994.

IBGE - Instituto Brasileiro de Geografia e Estatística. Manual técnico de pedologia. Rio de Janeiro, IBGE - Coordenação de Recursos Naturais e Estudos Ambientais, Manuais técnicos de geociências, ISSN 0103-9598, nº4, 2007. $323 \mathrm{p}$.

JACKSON, M. L. Clay transformation in soil genesis during the Quaternary. Soil Science, Baltimore, v.99, n.1, p.15-22, 1965.

KAMPF, N.; RESENDE, M.; CURI, N. Iron oxides in Brazilian oxisols. In: BEINROTH, F. H.; CAMARGO, M. N.; ESWARAN, H. (Eds.) Proceedings of the eighth International Soil Classification Worshop - Classification, Characterization and Utilization of Oxisols. Rio de Janeiro, p.71-77, 1998.

KAMPF, N.; CURI, N.; MARQUES, J. J.; Intemperismo e Ocorrência de minerais no ambiente do solo. In: MELO, V. F. e ALLEONI, L. R. F., eds. Química e Mineralogia do Solo: Conceitos básicos. Viçosa, MG. SBCS. Parte I. p.333379, 2009.

KAMPF, N.; MARQUES, J. J.; CURI, N. Mineralogia de solos brasileiros. In: KER, J. C.; CURI, N.; SCHAEFER, C. E. G. R.; VIDAL-TORRADO, P. Pedologia: Fundamentos. SBCS. 343p. 2012.

KER, J. C.; RESENDE, M. Recursos edáficos dos cerrados: ocorrência e potencial. In: Simpósio Nacional sobre o Cerrado; Internacional Symposium on Tropical 
Savannas. 8, 1996, Brasília, Planaltina. Anais... Brasília, Planaltina, EmbrapaCPAC, 1996. p.15-19.

KIEHL, E. J. Manual de Edafologia: relações solo-planta. São Paulo. Editora Agronômica Ceres LTDA, 1979. 263p.

KORNDÖRFER, G. H.; COELHO, N. M.; SNYDER, G. H.; MIZUTANI, C. T. Avaliação de métodos de extração de silício em solos cultivados com arroz de sequeiro. Revista Brasileira de Ciência do Solo, v.23, p.101-106, 1999.

LACERDA, M. P. C.; ANDRADE, H.; QUÉMENÉUR, J. J. G. Transformações mineralógicas ao longo de perfis de alteração pedogenética na região de Lavras (MG). Revista Brasileira de Ciência do Solo, v.25, p.799-809, 2001.

LACERDA, M. P. C.; ANDRAEDE, H.; QUÉMENÉUR, J. J. G. Pedogeoquímica em perfis de alteração na região de Lavras (MG). I - Elementos maiores e óxidos constituintes. Revista Brasileira de Ciência do Solo, v.26, p.75-85, 2002.

LACERDA, M. P. C.; QUÉMENÉUR, J. J. G.; ANDRADE, H.; ALVES, H. M. R.; VIEIRA, T. G. C. Estudo da relação pedomorfogeológica na distribuição de solos com horizonte B textural e B nítico na paisagem de Lavras (MG). Revista Brasileira de Ciência do Solo, v.32, p.271-284, 2008.

LACERDA, M. P. C.; QUÉMENÉUR, J. J. G.; ANDRADE, H.; ALVES, H. M. R.; VIEIRA, T. G. C. Mapeamento preliminar de solos com horizonte B textural e B nítico na região de Lavras, MG. Ciência e agrotecnologia, Lavras, v.33, n.3, p. 788-795, 2009.

LINDSAY W. L.; WALTHALL P. M. The solubility of aluminium in soils. In The environmental chemistry of aluminium. (G. Sposito, ed.), p.333-361. USA: Lewis Publishers, Boca Raton, 1996.

LOUGHNAN, F.C. Chemical weathering of the silicate minerals. New York, Elsevier, 1969. $154 \mathrm{p}$.

LUZ, L. R. Q. P.; SANTOS, M. C.; MERMUT, A. R. Pedogênese em uma topossequência do semi-árido de Pernambuco. Revista Brasileira de Ciência do Solo, v.16, p.95-102, 1992.

MACHADO, F. B.; MOREIRA, C. A.; ZANARDO, A.; ANDRE, A. C.; GODOY, A. M.; FERREIRA, J. A.; GALEMBECK, T.; NARDY, A. J. R.; ARTUR, A. C.; OLIVEIRA, M. A. F. Enciclopédia Multimídia de Minerais. [on-line]. $\quad$ ISBN: 85-89082-11- 
3. Disponível em <http:ww.rc.unesp.br/museudpm/banco/grm.html >. Acesso em: 07/01/2015.

MALAVOLTA, E. Elementos de nutrição mineral de plantas. São Paulo: Agronômica Ceres, 1980, $251 \mathrm{p}$.

MARTINS, E. S.; BAPTISTA, G. M. M. Compartimentação geomorfológica e sistemas morfodinâmicos do Distrito Federal. In: Inventário hidrogeológicos e dos recursos hídricos superficiais do Distrito Federal. Brasília, IEMA/SEMATEC/UnB, 1998. v.1, p.89- 137.

MARTINS, E. S.; REATTO, A.; CARVALHO JR, O. A.; GUIMARÃES, R. F. Evolução Geomorfológica do Distrito Federal. Planaltina, DF: Embrapa Cerrados, 2004. 57 p. - Documentos/Embrapa Cerrados, ISSN 1517-5111; n. 122.

MATOS, A. T.; FONTES, M. P. F.; JORDÃO, C. P.; COSTA, L. M. Mobilidade e formas de retenção de metais pesados em Latossolo Vermelho-Amarelo. Revista Brasileira de Ciência do Solo, v.20, 1996.

MELO JÚNIOR, A. S. Análise quantitativa do material particulado na região de Campinas através das técnicas de microfluorescência de raios-X e reflexão total usando radiação síncrotron. 2007. Tese (Doutorado). Unicamp: Campinas, São Paulo, 2007.

MELO, V. F. e WYPYCH, F. Caulinita e Haloisita. In: MELO, V. F. e ALLEONI, L. R. F., eds. Química e Mineralogia do Solo: Conceitos básicos. Viçosa, MG. SBCS. Parte I. p.427- 504. 2009.

MESQUITA FILHO, M. V.; TORRENT, J. Phosphate sorption as related to mineralogy of a hidrosequence of soils from the Cerrado region (Brazil). Geoderma, v.58, n.1, p.107-123, 1993.

MIRANDA, C. S. S.; FERREIRA, M. G. V. X. Caracterização de solos com A chernozêmico na Zona da Mata Norte do Estado de Pernambuco. Revista Brasileira de Ciência do Solo, v.23, p.107-120, 1999.

MOREAU, A. M. S. S.; KER, J. C.; COSTA, L. M.; GOMES, F. H. Caracterização de solos de duas topossequências em Tabuleiros Costeiros do Sul da Bahia. Revista Brasileira de Ciência do Solo, v.30, p.1007-1019, 2006.

MOREIRA, H. L.; OLIVEIRA, V. A. Evolução e gênese de um Plintossolo Pétrico concrecionário êutrico argissólico no município de Ouro Verde de Goiás., Revista Brasileira de Ciência do Solo, v.32, p.1683-1690, 2008. 
MOTTA, P. E. F. DA; CARVALHO FILHO, A.; KER, J.; PEREIRA, N.; CARVALHO JUNIOR, W.; BLANCANEAUX, P. Relações solo-superfície geomórfica e evolução da paisagem em uma área do Planalto Central Brasileiro. Pesquisa Agropecuária Brasileira. Brasília, v.37, n.6, p.869-878, 2002.

NETO, A. R. Influência da mineralogia da fração argila sobre propriedades físicoquímicas dos solos brasileiros. 1996. 144p. Dissertação (Mestrado). Universidade Federal de Viçosa, Viçosa. 1996.

NETO, F. C. R.; SCHAEFER, C. E. G. R.; FILHO, E. I. F.; CORRÊA, M. M.; COSTA, L. M.; PARAHYBA, R. B. V; GUERRA, S. M. S.; HECK, R. Topolitossequências de solos do Alto Paranaíba: atributos físicos, químicos e mineralógicos. Revista Brasileira de Ciência do Solo, v.33, p.1795-1809, 2009.

NOVAES PINTO, M. Caracterização Geomorfológica do Distrito Federal. In: NOVAES, M.P. (Org.) - Cerrado - Caracterização, Ocupação e Perspectivas. Brasília, Editora Universidade de Brasília, 1994, p. 285-320.

NUNES, W. A . G. A.; KER, J. C.; SCHAEFER, C. E. G. R.; FERNANDES FILHO, E. I.; GOMES, F. H. Relação solo-paisagem-material de origem e gênese de alguns solos no domínio "Mar dos Morros", Minas Gerais. Revista Brasileira de Ciência do Solo, v.25, p.341-354, 2001.

OLIVEIRA, T.S. Metais pesados como indicadores de materiais de origem de solos. 1996. 128p. Tese (Doutorado). Universidade Federal de Viçosa, Viçosa. 1996.

PENTEADO, O.M.M. Tipos de concreção ferruginosa nos compartimentos geomorfológicos do Planalto de Brasília. Not. Geom., v.16. p.39-53, 1976.

PEREIRA, M. G.; SCHIAVO, J. A.; FONTANA, A.; DIAS NETO, A. H.; MIRANDA, L. P. M. Caracterização e classificação de solos em uma topossequência sobre calcário na Serra da Bodoquena, MS. Revista Brasileira de Ciência do Solo, v.37, p.25-36, 2013.

RAIJ, B. van. Fertilidade do solo e adubação. São Paulo: Agronômica Ceres, 1991, 343p.

RAIJ, B.van; CAMARGO, O. A. Sílica solúvel em solos. Bragantia, v. 32, p. 223-231, 1973.

RAIJ, B. V. A capacidade de troca de cátions das frações orgânicas e mineral em solos. Campinas, Bragantia, v.28. n.único, 1969. 
REATtO, A.; CORREIA, MARTINS, E. S.; FARIAS, M. F. R.; SilVA, A. V. Relação entre Classes de Solos e as Fitofisionomias da Área de Preservação Ambiental - APA de Cafuringa, escala 1:100.000. Planaltina: Embrapa Cerrados, 2002a.

REATTO, A.; CORREIA, MARTINS, E. S.; FARIAS, M. F. R.; SILVA, A. V.; SPERA, S. T. Levantamento de Reconhecimento de Alta Intensidade dos solo da APA de Cafuringa - DF, escala 1:100.000. Planaltina: Embrapa Cerrados, 2002b.

RESENDE, M.; SANTANA, D. P.; CURI, N. Pedologia e fertilidade do solo: interações e aplicações. Lavras: Esal, 1988. 81 p.

RESENDE, M.; CURI, N.; REZENDE, S. B.; CORRÊA, G. F.; Pedologia: Base para distinção de ambientes, $5^{\mathrm{a}}$ ed., UFLA: Lavras, 2007. 322p.

RESENDE, M.; SANTANA, D. P. Uso das relações $\mathrm{Ki}$ e $\mathrm{Kr}$ na estimativa da mineralogia para classificação dos Latossolos. In: Reunião de Classificação, Correlação de Solos e Interpretação de Aptidão Agrícola, 3, 1998. Rio de Janeiro. Anais... Rio de Janeiro, Embrapa-SNLCS, 1998. p.225- 232.

ROLIM NETO, F. C.; SANTOS, M. C. gênese de solo arenoso com lamelas e fragipã no agreste de Pernambuco. Revista Brasileira de Ciência do Solo, v.18, p.243253, 1994.

ROVERS, H.; CAMARGO, O.A.; VALADARES, J.M.A.S. Níquel total e solúvel em DTPA em solos do Estado de São Paulo. Revista Brasileira de Ciência do Solo, Campinas, v.7, n.3, p.217-220, 1983.

SANTOS, R. D.; LEMOS, R. C.; SANTOS, H. G.; KER, J. C.; ANJOS, L. H. C.

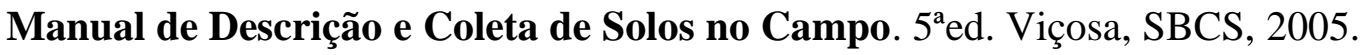
$92 \mathrm{p}$.

SANTOS, A. C.; PEREIRA, M. G.; ANJOS, L. H. C.; BERNINI, T. A.; COOPER, M.; NUMMER, A. R.; FRANCELINO, M. R. Gênese e classificação de solos numa topossequência no ambiente de Mar dos Morros do Médio Vale do Paraíba do Sul, RJ. Revista Brasileira de Ciência do Solo, v.34, p.1297-1314, 2010.

SCHEFFER, F., E. WELTE; F. LUDWIEG. Zur Frage der Eisenoxid-hydrate im Boden. (In German.) Chem. Erde, n.19, p.51-64, 1958.

SCHWERTMANN, U., TAYLOR, R.M. Iron oxides. In: DIXON, J.B.; WEED, S.B., eds. Minerals in soil environments. Madison, Soil Science Society of America, 1989. p.379-438. 
SCHWERTMANN, U. Relations between iron oxides, soil color, and soil formation. In: BIGHAM, J.M.; CIOLKOSZ, E.J. (Ed.). Soil color. Madison: Soil Science Society of America, 1993. p.51-70. (Special Publication, 31).

SEMARH - Secretaria de Meio Ambiente e Recursos Hídricos do Distrito Federal. Geomorfologia da APA de Cafuringa. 2006. Site: http://www.semarh.df.gov.br/semarh/site/cafuringa/Sec02/Frameset_cap2_4.ht. Acesso em: 15/01/2014.

SHERMAN, G. D. Mineral weathering in relation to utilization of soils. In: Soils and Tropical Weatherig. Proceedings of the Bandung Symposium. UNESCO, Paris, p.7-51, 1971.

SHINZATO, E. O carste da área de proteção ambiental de Lagoa Santa (MG) e sua influência na formação de solos. 1998. 99p. Dissertação (Mestrado). Universidade Estadual do Norte Fluminense, Campos dos Goytacazes. 1998.

SILVA, M. B.; ANJOS, L. H. C.; PEREIRA, M. G.; SCHIAVO, J. A.; COOPER, M.; CAVASSANI, R. S. Gênese e classificação dos solos de uma topossequência em área de carste na Serra da Bodoquena, MS. Revista Brasileira de Ciência do Solo, v.37, p.1464-1480, 2013.

SLAGLE, A. Background concentrations of trace elements in three West Virginia soils. 2000. 174p. Dissertação (Mestrado). College of Agriculture, Forestry, and Consumer Sciences at West Virginia University, Morgantown. 2000.

SODRÉ, F. F.; LENZI, E.; COSTA, A. C. S. Utilização de modelos físico-químicos de adsorção no estudo do comportamento do cobre em solos argilosos. Química Nova, v.24, n.3, p.324-330, 2001.

SOUZA, A. E. Balanço Mineral Brasileiro. Brasília, Departamento Nacional de Produção Mineral, 2001. 31 p.

SOUZA, R. Q.; LACERDA, M. P. C.; NEUMANN, M. R. B., BORGES, T. D.; MICAS, G. Q.; DUARTE, J. L. P. Aplicação de geotecnologias no estabelecimento das relações entre solos, geologia e geomorfologia na Área de Proteção Ambiental de Cafuringa a fim de gerar um modelo de distribuição de solos nessa APA do Distrito Federal. In: Simpósio Brasileiro de Sensoriamento Remoto, Foz do Iguaçu, PR, 16, 2013, Anais... Foz do Iguaçu, INPE, 2013.

TILLER, K.G. Heavy metals in soil and their environmental significance. Advances in Soil Science, New York, v.9, p.113-142, 1989. 
TREMOCOLDI, W. A. Mineralogia dos silicatos e dos óxidos de ferro da fração argila de solos desenvolvidos de rochas básicas no estado de São Paulo. Revista Biociências. Taubaté, v.9, n.1, p.15-22, 2003.

VALADARES, J.M.A.S. Cobre em solos do Estado de São Paulo: cobre total. Bragantia, Campinas, v.34, p.125- 132, 1975.

VAN SCHUYLENBORGH, J. Weathering and soil forming processes in the tropics. In: Soils and Tropical Weatherig. Proceedings of the Bandung Symposium. UNESCO, Paris, p.39-50, 1971.

VIEIRA, V. A. S.; MELLO, C. R.; LIMA, J. M. Variabilidade espacial de atributos físicos do solo em uma microbacia hidrográfica. Ciência e Agrotecnologia, Lavras, v.31, n.5, p. 1477-1485, 2007.

ZEE, Zoneamento Ecológico Econômico do Distrito Federal. Greentec Consultoria e Planejamento Ltda, Brasília, 2011. 172p. 


\section{MAPEAMENTO DIGITAL DOS SOLOS COM HORIZONTE B TEXTURAL E B NÍTICO EM UMA ÁREA PILOTO DO PLANALTO CENTRAL DO BRASIL ${ }^{1}$}

\section{Rosana Quirino de Souza ${ }^{2} \&$ Marilusa Pinto Coelho Lacerda ${ }^{3}$}

${ }^{1}$ Projeto desenvolvido com apoio financeiro da CAPES e FINATEC

${ }^{2}$ Aluna do Programa de Mestrado e Doutorado em Agronomia, Área de concentração em Produção Sustentável e linhas de pesquisa em Solo, água e qualidade ambiental, da Faculdade de Agronomia e Medicina Veterinária, da Universidade de Brasília, Campus Universitário Darcy Ribeiro, Instituto Central de Ciências Ala Sul, Caixa Postal 4.508, CEP: 70.910-970, Brasília, DF, rosanakirino@gmail.com

${ }^{3}$ Professora Associado III da Faculdade de Agronomia e Medicina Veterinária da Universidade de Brasília.

\section{RESUMO}

O mapeamento digital de solos embasado nas relações solo-paisagem e na validação em campo tem-se mostrado uma importante ferramenta no estudo da distribuição e da predição dos solos na paisagem. O objetivo do presente estudo foi gerar um modelo de distribuição pedológica, com enfoque para os solos com horizonte B textural e B nítico, na microbacia do Ribeirão Salinas, Distrito Federal (DF), e por meio deste realizar o mapeamento digital dos solos. Este trabalho foi motivado pela ocorrência restrita desses solos no Planalto Central do Brasil. Partindo do Modelo Digital de Terreno - MDT e dos atributos derivados dele, tais como altimetria, declividade e curvatura, juntamente com o mapa disponível de geologia, foi possível estabelecer as relações pedomorfogeológicas da área de estudo, que possibilitou a elaboração do modelo de distribuição de solos da microbacia do Ribeirão Salinas, DF. A partir desse modelo foi realizado o mapeamento digital dos solos por meio do programa ArcGIS, utilizando a lógica fuzzy. Os pesos atribuídos aos fatores utilizados (altimetria, declividade, curvatura e geologia) variaram de 0 a 1 de acordo com o grau de pertinência do parâmetro para cada classe de solo pré-determinada. A integração dos mapas de evidência para cada classe de solo foi realizada por meio do operador lógico fuzzy AND. Os mapas obtidos foram reclassificados e combinados para gerar o mapa 
digital de solos da microbacia do Ribeirão Salinas, DF. Foram identificadas cinco classes de solos com horizonte B textural e B nítico: Argissolo Vermelho-Amarelo, Nitossolo Vermelho, Nitossolo Háplico, Chernossolo Argilúvico e Chernossolo Háplico. A acurácia global do mapeamento foi de 77\% e o índice Kappa foi 71,35\%, resultado considerado muito bom, no mapeamento digital temático.

Palavras-chave: Pedometria, SIG, validação, distribuição de solos, paisagem, geologia.

\begin{abstract}
The soil digital mapping founded in soil-landscape relations and field validation has been an important tool in the study of the distribution and prediction of soil in the landscape. The aim of this study was to generate a pedological distribution model, focusing on soil with argillic horizons in the Ribeirão Salinas watershed, Distrito Federal, and hereby make the soils digital mapping. This work was motivated by the restricted occurrence of these soils in the Central Brazilian Plateau. From the Digital Terrain Model - DTM and attributes derived from it, such as altitude, slope and curvature together with the geology map available was possible to establish the pedomorfogeologicals relations of the study area, which is possible the development soils distribution model of the Ribeirão Salinas watershed, DF. From this model was performed the soils digital mapping, through the ArcGIS software, by fuzzy inference. The weights assigned to the factors used (altitude, slope, curvature and geology) varied from 0 to 1 according to the degree of relevance of the parameter for each predetermined soil class. The integration of evidence maps for each soil class was performed using the logical operator fuzzy AND. The maps obtained were reclassified and combined to generate the soil digital map of the Ribeirão Salinas watershed. Five soil classes were identified with argillic horizons: : Ultisols, Alfisols (Chernosols) and Kandic Oxisols, The overall accuracy of the mapping was $77 \%$ and the Kappa index was $71,35 \%$, considered very good result, thematic mapping.
\end{abstract}

Key-words: Pedometrics, GIS, validation, soil distribution, landscape, geology. 


\section{1- INTRODUÇÃO}

Cada vez mais, o conhecimento detalhado dos solos é reconhecido, pela sua importância não só para os ecossistemas, como também para a produção de alimentos e regulação do clima global. Por esse motivo, a busca por informações atualizadas em solos está crescente (Sanchez, 2009).

A disponibilidade de informações sobre os solos, suas características e distribuição, são fundamentais para planejamento de atividades relacionadas ao manejo, uso e potencialidades de uso dos solos. O Brasil, assim como a maioria do Planalto Central do Brasil, possui a totalidade de seu território coberto por mapas de solos na escala 1:1.000.000, gerados por meio de levantamentos realizados em 1986 pelo projeto RADAMBRASIL (Coelho, 2010).

No Brasil, a execução de mapeamentos de solos é uma demanda permanente na busca de informações para diversos estudos pedológicos, tais como planejamento da ocupação racional das terras, gestão ambiental, conservação e proteção dos recursos naturais. Embora exista essa enorme demanda, são várias as limitações para a aquisição dessas informações, destacando-se o elevado custo dos levantamentos, a extensão das áreas a serem mapeadas no país e a dificuldade de acesso em alguns lugares. Somam-se ainda os problemas relacionados à precisão das informações, em função das escalas de pouco detalhamento dos mapeamentos e dificuldade de extrapolação dos dados para outras áreas (Mendonça-Santos e Santos, 2003).

Diante desse cenário, o uso de técnicas quantitativas para predição espacial em mapeamento de solos e de seus atributos (tanto químicos, quanto físicos e biológicos) vem crescendo nesta última década, devido ao avanço na capacidade de processamento dos computadores, o que permite usar de maneira mais rápida, os métodos matemáticos e estatísticos, sendo que alguns dos quais já vinham sendo aplicados em Ciência do Solo, desde a década de 60 (McBratney et al., 2000).

Aliados ao desenvolvimento da computação e das tecnologias de informação foram gerados os sistemas de informação geográfica (SIGs) e os sistemas de posicionamento global (GPSs). Estas tecnologias progridem rapidamente com a evolução dos produtos e técnicas de sensoriamento remoto, metodologias de geração de modelos digitais de terreno, desenvolvimento de ferramentas geoestatísticas, e estabelecimento de modelagens e tecnologias de monitoramento ambiental. Neste contexto foram criadas várias ferramentas para criação e análise de dados espaciais, 
aplicados em vários ramos da ciência, inclusive na Ciência do Solo (McBratney et al., 2003), onde este conjunto de técnicas tem recebido o nome de mapeamento digital de solos (MDS). De acordo com Valladares (2012) tais técnicas são muito úteis em áreas de estudo com informações ambientais esparsas, ou de difícil acesso, além de reduzirem a densidade de trabalhos de campo e o custo dos levantamentos e mapeamentos tradicionais de solos.

O MDS se baseia na geração de sistemas de informações que permitem estabelecer relações matemáticas entre variáveis ambientais e atributos de classes de solos e, assim, predizer a distribuição espacial das classes de solos com significativa semelhança aos mapas gerados por meios convencionais (Lagacherie e McBratney, 2007).

Nos últimos anos alguns autores aplicaram diferentes técnicas de mapeamento digital de solos no Brasil, tais como redes neurais artificiais (Arruda et al., 2013; Chagas et al., 2011; Sarmento, 2010) regressões logísticas múltiplas (Giasson et al., 2006; Ten Caten et al., 2011); árvores de decisão (Crivelenti et al., 2009; Giasson et al., 2011) lógica fuzzy (Nolasco-Carvalho et al., 2009); krigagem (Valladares, 2012; Kraemer, 2007) e geotecnologias diversificadas (Loss et al., 2011; López, 2009; Demattê et al., 2004; Farias, 2008; Sousa Junior e Demattê, 2008).

No Distrito Federal (DF), a principal fonte de informações pedológicas ainda é o Levantamento de Reconhecimento de Solos realizado pela Embrapa (1978), com elaboração de mapa pedológico em escala 1:100.000. Os dados disponíveis gerados nessa escala não possibilitam uma caracterização detalhada dos solos e o entendimento das relações entre os seus materiais de origem e superfícies geomorfológicas, responsáveis pela distribuição destes na paisagem do DF.

De acordo com Barbosa et al. (2009) trabalhos vêm sendo desenvolvidos no Distrito Federal com a finalidade de estudar a gênese e morfologia dos solos, porém, estes trabalhos vêm sendo executados de maneira pontual e fragmentada.

Em trabalho recente Neumann (2012) aplicou o modelo de regressão linear múltipla, para o mapeamento de solos, utilizando distintos modelos digitais de elevação, no DF e verificou que essa metodologia apresentou desempenho satisfatório para mapeamento das classes de solos, Latossolos Vermelhos, Latossolos VermelhoAmarelos e Cambissolos.

Outra técnica que vem sendo extensamente utilizada em MDS é a modelagem por inferência fuzzy que permite simular, por meio do uso de possibilidades, as 
incertezas e transições tão comuns nos sistemas pedológicos, que é feita correlacionando-se o grau de certeza à experiência e ao conhecimento acumulados do pedólogo (Nolasco-Carvalho, 2009).

Lima (2013) aplicou métodos semi-automático e lógica fuzzy para o mapeamento de solos na Bacia do Sarandi, DF, constatando que a aplicação da lógica fuzzy para o mapeamento de classes de solo possibilitou entre outros fatores a identificação das classes condizentes com a resolução da base de dados morfométricos utilizada (30m), delimitação das unidades de mapeamento com limites semelhantes aos obtidos por metodologia semi-automática, e eliminação de parte da subjetividade no mapeamento.

Nesse contexto, o objetivo do presente estudo foi o mapeamento digital dos solos com emprego da lógica fuzzy na paisagem da microbacia do Ribeirão Salinas, Distrito Federal (DF), mediante a geração de um modelo de distribuição pedomorfogeológica. O mapeamento enfatizou as classes de solos com B textural e B nítico, que são solos de ocorrência restrita no Planalto Central do Brasil.

\section{2 - MATERIAL E MÉTODOS}

\subsection{1 - Caracterização da área de estudo}

A área de estudo localiza-se na porção noroeste do Distrito Federal - DF, entre as coordenadas geográficas $15^{\circ} 30^{\prime}$ e $15^{\circ} 35^{\prime}$ de latitude sul e $47^{\circ} 54^{\prime}$ e $47^{\circ} 58^{\prime}$ longitude oeste (datum horizontal SIRGAS 2000). Tal microbacia encontra-se inserida na Área de Proteção Ambiental de Cafuringa, que possui 46.000 ha e limita-se ao sul com as rodovias DF 001 e DF 220, ao norte e oeste pela divisa do Distrito Federal com Goiás, e a leste com a rodovia DF 150 e o Ribeirão da Contagem (Figura 13). 


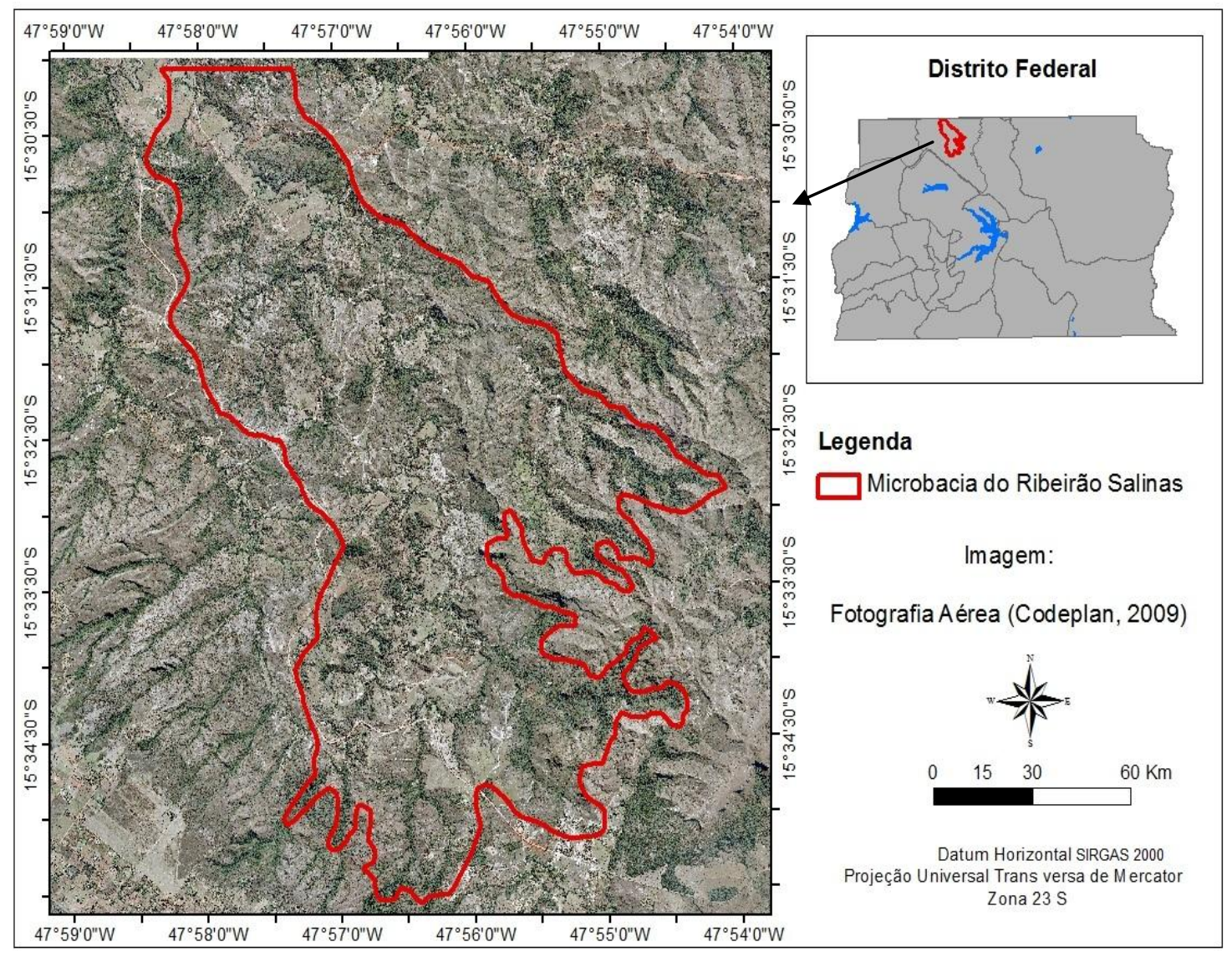

Figura 13. Localização da microbacia do Ribeirão Salinas, DF. Fotografia Aérea (Codeplan, 2009).

\subsubsection{1 - Caracterização do meio físico da microbacia do Ribeirão Salinas, DF.}

O substrato geológico da área de estudo é caracterizado de acordo com FreitasSilva e Campos (1998) e SEMARH (2006) principalmente pelas unidades litológicas do Grupo Canastra, tais como as unidades MNPccf - clorita carbonato filito, formado por fengita filitos, clorita filitos e constantes lentes de quartizitos micáceos; MNPcf carbonato filito, formado por clorita-fengita filitos associados a mármores calcíticos e dolomíticos impuros (clorita mármores finos) e lentes calcárias cujas litologias favorecem a formação de classes de solos pouco comuns na região do Planalto Central do Brasil, tais como os Argissolos, Chernossolos e Nitossolos. Ocorrem secundariamente, litologias psamo-pelito-carbonatadas relacionadas ao Grupo Paranoá, da unidade MNPppc, formada por metassiltitos argilosos com lentes e camadas de quartzitos e lentes de rochas metacarbonáticas. 
Quanto à geomorfologia, de acordo com (Penteado, 1976; Codeplan, 1984; Novaes Pinto, 1994; Martins e Baptista, 1998; Motta, 2002; SEMARH, 2006) é a região da microbacia estudada localiza-se em apenas um compartimento geomorfológico, denominado de Terceira Superfície Geomorfológica do Distrito Federal, e corresponde às porções que apresentam litologias com resistências ao intemperismo variadas, ocupada pelas principais drenagens da região, pertencentes ao curso superior do rio Maranhão, cujas altitudes variam entre 750 e 950 m. Apresenta relevo acidentado com declividade variável, mas geralmente superior a $20 \%$, com encostas de perfil convexocôncavo e perfil complexo que inclui o segmento retilíneo. A rede de drenagem está condicionada por fraturamentos e por zonas de contato entre litologias de resistências diversificadas ao intemperismo (Novaes Pinto, 1994). Apresenta-se com uma área intensamente dissecada, onde as variações topográficas resultam da contraposição entre camadas areno-argilosas do Grupo Paranoá e meta-calcárias e calcio-xistos do Grupo Canastra, com vertentes abruptas e vales encaixados.

Na microbacia do Ribeirão Salinas são encontradas cinco classes de solos de acordo com Embrapa (1978), Reatto et al. (2002) e Martins et al. (2004): Latossolos, Cambissolos, Neossolos, Argissolos, Nitossolos e Chernossolos.

Os Latossolos Vermelhos desenvolvem-se nos topos da Terceira Superfície aplainada, sob substrato psamo-pelito-carbonatado, constituído por filitos e lentes de calcário. Encontram-se relacionados às fitofisionomias de Floresta Tropical Subcaducifólia e Cerradão. Já os Latossolos Vermelho-Amarelos ocorrem no terço médio a inferior das encostas, também em substrato psamo-pelito-carbonatado, associados às fitofisionomias de Cerrado Típico.

Os Cambissolos ocorrem em diferentes substratos, tais como filitos, rochas psamo-pelito-carbonatadas e lentes de calcário em relevo ondulado a forte ondulado, com desenvolvimento de vegetação nativa de Cerrado Típico, Floresta, Cerrado Rupestre e Campo Sujo.

Os Neossolos, representados pelos Neossolos Litólicos e Neossolos Regolíticos, normalmente ocorrem em áreas bastante acidentadas, em relevo ondulado, forte ondulado até montanhoso, sob fitofisionomia Cerrado Típico. No contexto da microbacia, ocorrem associados a Cambissolos Háplicos.

Os Argissolos, por sua vez, ocorrem em relevo suave ondulado transicionando para ondulado a forte ondulado, em encostas convexo-côncavas e com associação frequente de fitofisionomias de Mata Seca Semidecídua. 
Já os Nitossolos e Chernossolos desenvolvem-se na posição inferior das encostas convexas em direção às linhas de drenagem, em relevo ondulado a forte ondulado, sob diferentes substratos geológicos, tais como rochas psamo-pelito-carbonatadas, filitos e lentes de meta-calcário, com vegetação nativa constituída por fitofisionomias de Mata Seca Semidecídua.

Quanto ao relevo na área de estudo são verificadas cinco fases de relevo de acordo com Embrapa (1978):

Plano: Superfície de topografia lisa ou horizontal, onde os desnivelamentos são muito pequenos, com declividades inferiores a $3 \%$.

Suave Ondulado: Superfície de topografia ligeiramente movimentada, constituída por conjunto de pequenas colinas ou outeiros, ou sucessão de pequenos vales pouco encaixados (rasos), configurando pendentes ou encostas com declives entre 3 até $8 \%$.

Ondulado: Superfície de topografia relativamente movimentada, constituída por conjunto de medianas colinas e outeiros, ou por interflúvios de pendentes curtas, formadas por vales encaixados, configurando em todos os casos pendentes ou encostas com declives maiores que $8 \%$ até $20 \%$.

Forte Ondulado: Superfície de topografia movimentada, com desníveis fortes, formadas por conjunto de outeiros ou morros, ou por superfície entrecortada por vales profundos, configurando encostas ou pendentes com declives maiores que $20 \%$ até $45 \%$.

Montanhoso: Superfície de topografia fortemente movimentada, com predomínio de formas acidentadas, usualmente constituídas por morros, montanhas, maciços e alinhamentos montanhosos, apresentando desnivelamentos relativamente grandes e declives fortes ou muito fortes, predominantemente maiores de $45 \%$.

O clima da região é do tipo Aw, tropical, com temperatura do mês mais frio superior a $18{ }^{\circ} \mathrm{C}$ em média e com estações chuvosa e seca (SEMARH, 2006).

De acordo com Martins e Baptista (1998) o clima apresenta forte sazonalidade, assim como o clima do Distrito Federal, com uma estação chuvosa e quente e outra fria e seca. A estação chuvosa inicia-se em outubro e termina em abril, perfazendo aproximadamente $85 \%$ da precipitação total anual, sendo janeiro o mês com maior índice pluviométrico médio (320 mm/mês). A estação seca se estende de maio a setembro, sendo que a precipitação representa somente $2 \%$ do total anual, não 
ultrapassando $50 \mathrm{~mm} / \mathrm{mês}$. Na região da microbacia estudada, a precipitação anual varia entre $1.500 \mathrm{~mm}$ a $1.700 \mathrm{~mm}$.

Quanto à vegetação, a microbacia do Ribeirão Salinas apresenta grande variedade, desde campos limpos até matas de galeria e matas estacionais em solos férteis sobre rochas meta-calcárias. A diversidade de ambientes reflete-se em elevada diversidade florística. São muitas as espécies de plantas, desde pequenas ervas até grandes árvores com mais de $20 \mathrm{~m}$ de altura. As matas mesofíticas constituem ambiente pouco comum no Brasil Central, associado a rochas meta-calcárias e com uma flora relacionada à da caatinga arbórea (SEMARH, 2006).

As variações nos ambientes são grandes, encontrando-se quase todas as fisionomias vegetais do bioma Cerrado: Campo Limpo, Cerrado Stricto Sensu, Cerradão, Vereda, Mata de Galeria e Matas Estacionais (SEMARH, 2006).

\subsection{2 - Modelo de distribuição dos solos da microbacia do Ribeirão Salinas, DF}

Primeiramente foi realizado o levantamento e aquisição de dados digitais da área de estudo tais como mapa pedológico (Embrapa, 1978) e mapa geológico (Freitas-Silva e Campos, 1998), ambos em escala 1:100.000 e dados planialtimétricos, ou seja; curvas de nível, redes de drenagem e pontos cotados da base de dados da Codeplan/SICAD (1991) em escala 1:10.000. Os dados foram implementados em ambiente SIG por meio do software ArcGIS. Após a geração do banco de dados digitais foi confeccionado o vetor do limite da microbacia do Ribeirão Salinas, o qual foi utilizado posteriormente no recorte dos mapas existentes de solos, geologia e outros da área de estudo.

Por meio dos dados planialtimétricos e do vetor do limite da microbacia do Ribeirão Salinas foi elaborado o Modelo Digital de Terreno (MDT) da área de estudo. Por meio deste foram gerados os mapas de declividade, altimetria e curvatura, entre outras feições do relevo. Posteriormente, esses dados, juntamente com o mapa geológico, foram manipulados no software ArcGIS para o estabelecimento das relações pedomorfogeológicas da área de estudo. A figura 14 apresenta um fluxograma resumindo a metodologia utilizada neste estudo. 


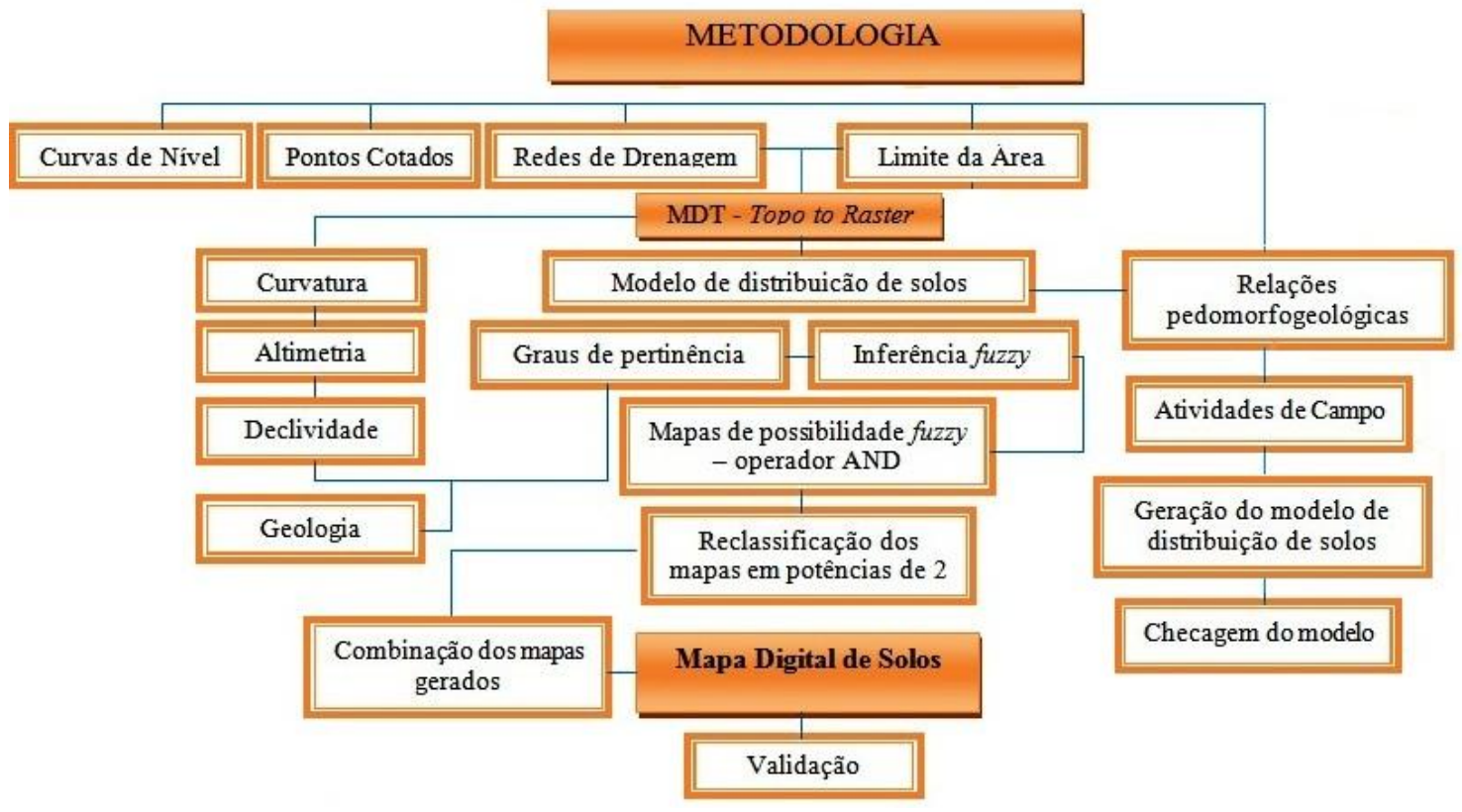

Figura 14. Fluxograma resumido da metodologia utilizada neste estudo.

O Modelo Digital do Terreno (MDT) foi gerado no software ArcGIS utilizandose o módulo Spatial Analyst Tools por meo do interpolador Topo to Raster. Segundo os autores Guimarães (2000) e Barbosa (2007) esta ferramenta, dentre as demais metodologias utilizadas para realizar a modelagem do terreno, apresenta uma maior eficiência quando comparada com a topografia real do terreno devido a essa técnica ter sido desenvolvida com o objetivo específico de converter dados vetoriais em modelos hidrológicos exatos de elevação de terreno. O método se utiliza da eficiência computacional da interpolação local, como ponderação do inverso da distância, sem perder a continuidade superficial dos métodos globais de interpolação, como krigagem e spline (Júnior et al., 2012).

O MDT foi posteriormente reclassificado para gerar o mapa de altimetria da área de estudo, porém, devido à região da microbacia encontrar-se totalmente inserida na Superfície Geomorfológica mais recente do Distrito Federal, Terceira Superfície, o mapa apresenta apenas uma classe de altimetria, que varia de 750 a $1.000 \mathrm{~m}$, que representa a Terceira Superfície Geomorfológica do Distrito Federal (Motta et al., 2002) (Figura 15)

Por meio do MDT foi gerado o mapa de classes de declividade da microbacia do Ribeirão Salinas por meio do módulo Spatial Analyst Tools $\rightarrow$ Surface $\rightarrow$ Slope que foi reclassificado em quatro classes: $0-10 \%, 10-24 \%, 24-45 \%$, e $>45 \%$, que foram 
definidas por meio de leituras de clinômetro nas atividades de campo. $\mathrm{O}$ critério adotado para o estabelecimento das classes de declividade da área de estudo foi o de determinar intervalos que individualizassem o desenvolvimento das classes de solos com horizonte B textural e B nítico, das demais classes de solos que ocorrem na região da microbacia Latossolos, Cambissolos e Neossolos (Figura 15).

A partir do MDT, também foi elaborado o mapa de curvatura da área de estudo. Primeiramente o MDT foi exportado para o software SAGA GIS, por ser este software mais eficiente na geração de atributos do terreno. Por meio do módulo Terrain Analysis $\rightarrow$ Compound Analysis $\rightarrow$ Basic Terrain Analysis foram gerados os mapas dos principais atributos do terreno, dentre eles o mapa de curvatura. Posteriormente o mapa de curvatura foi exportado para o ArcGIS e reclassificado em três classes de curvatura: côncava, linear e convexa (Figura 15).

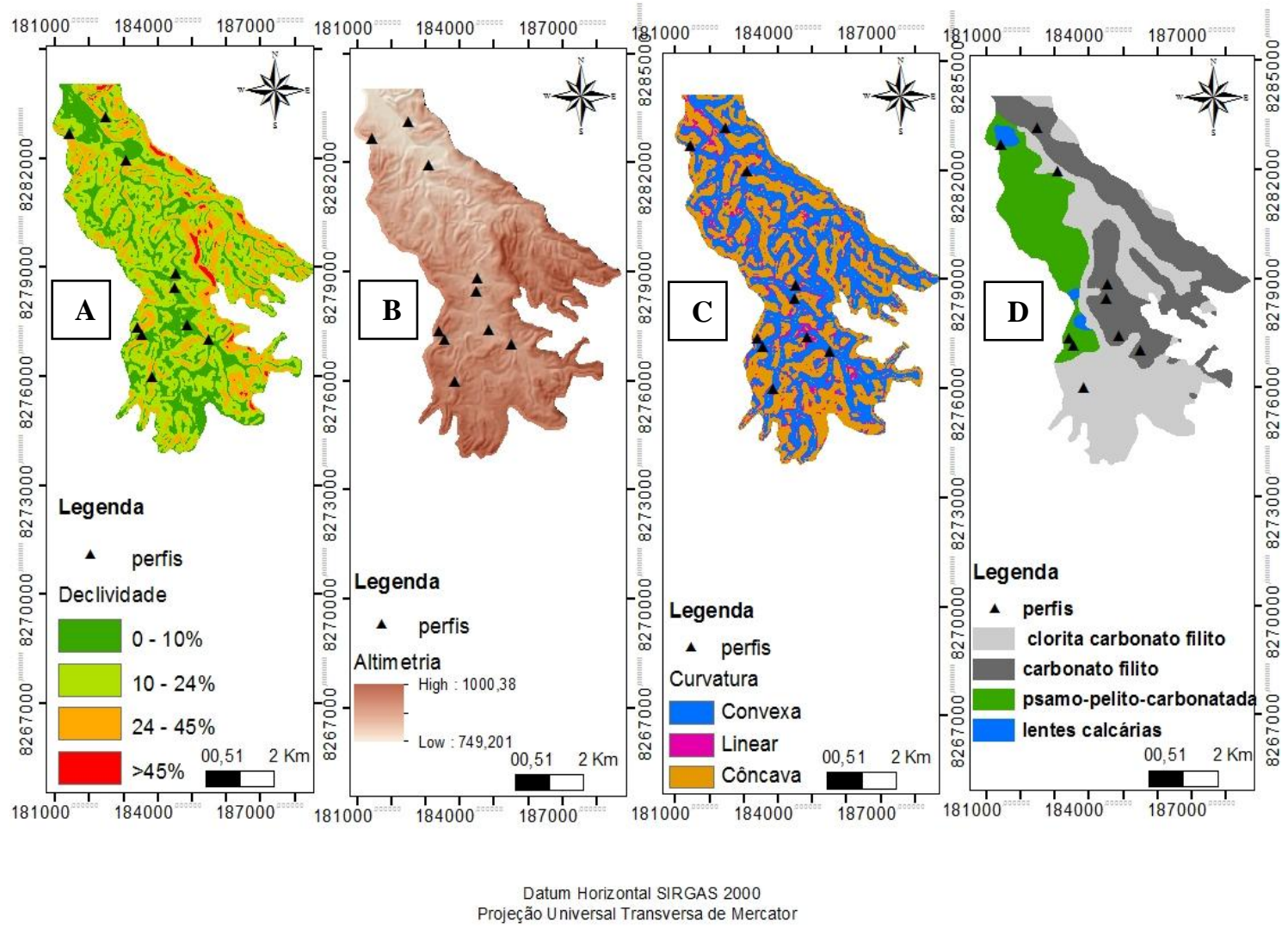

Figura 15. A) Mapa de classes de declividade, B) Mapa de altimetria, C) Mapa de curvatura e D) Mapa de geologia (Freitas-Silva e Campos, 1998) da microbacia do Ribeirão Salinas, DF. 
Todos os mapas foram convertidos para o formato raster (matricial) para serem utilizados em operações de soma e sobreposição de mapas.

\subsubsection{1 - Estabelecimento das relações pedomorfogeológicas da microbacia do Ribeirão Salinas, DF}

O estabelecimento das relações pedomorfogeológicas da área de estudo, realizado mediante a avaliação das relações entre as formações geológicas, a variação geomorfológica e as classes de solos formadas, permitiu a elaboração do modelo preliminar de distribuição dos solos na paisagem da microbacia estudada. Este modelo foi checado e validado em campanhas de campo, por meio de caracterização detalhada de classes de solos em geo-topossequências representativas, juntamente com a avaliação das feições de relevo e materiais de origem associados.

Desta forma, o modelo de distribuição de solos da área de estudo é resultado da associação das unidades geológicas (materiais de origem) (Figura 16) com as feições do relevo, tais como altimetria, declividade e curvatura. Assim, os fatores de formação dos solos considerados no modelo foram aqueles que mostram o controle da pedogênese de classes diferenciadas de solos com horizonte B textural e B nítico na área estudada, além das demais classes de solo de ocorrência, como Neossolos Regolíticos e Litólicos, Cambissolos e Latossolos (Tabela 19 e Figura 16).

A fim de uniformizar a escala do mapeamento da microbacia de estudo, o mapa geológico disponível em escala 1:100.000 (Freitas-Silva e Campos, 1998) (Figura 16) foi detalhado em atividades de campo, em escala compatível com os mapas gerados de feições do relevo, particularmente ao longo das geo-topossequências que constituíram a metodologia de prospecção de campo adotada no mapeamento realizado, cuja escala final foi $\leq 1: 20.000$. 


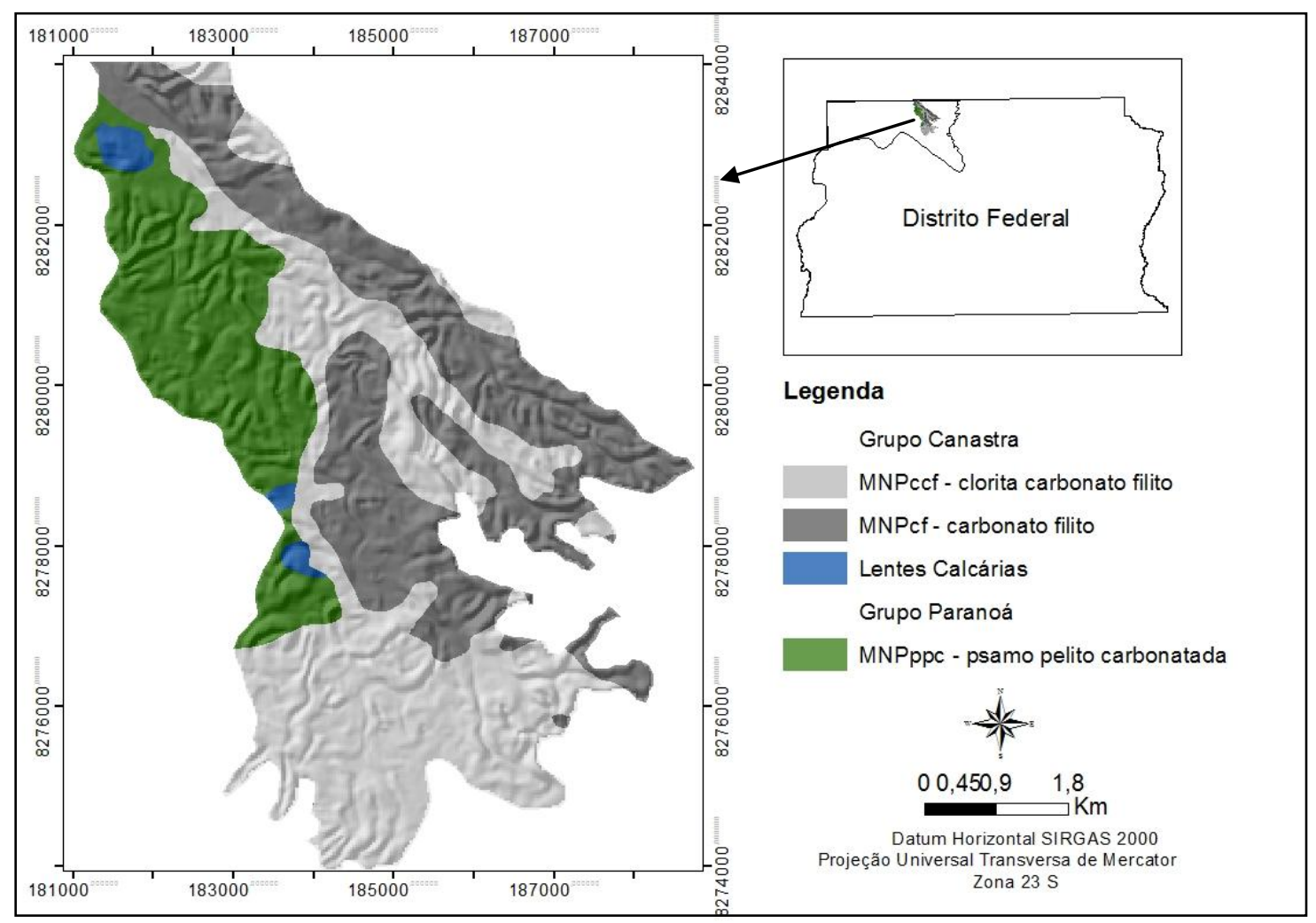

Figura 16. Mapa geológico da microbacia do Ribeirão Salinas, DF. (Fonte: FreitasSilva e Campos, 1998).

Tabela 19. Modelo de distribuição de solos na paisagem da microbacia do Ribeirão Salinas, DF.

\begin{tabular}{|c|c|c|c|c|}
\hline & \multicolumn{4}{|c|}{ Classe de Declividade (na classe altimétrica de 750 a $1.000 \mathrm{~m}$} \\
\hline $\begin{array}{c}\text { Domínios } \\
\text { Geológicos }^{(1)}\end{array}$ & $0-10 \%$ & $10-24 \%$ & $24-45 \%$ & $>45 \%$ \\
\hline MNPppc & $\mathrm{LVA}+\mathrm{LV}$ & PVA & $\mathrm{PVA}+\mathrm{CX}$ & $\mathrm{CX}+\mathrm{RR}+\mathrm{RL}+\mathrm{AF}$ \\
\hline MNPccf & $\mathrm{LV}+\mathrm{LVA}$ & $\begin{array}{c}\mathrm{PVA}+\mathrm{PV}+ \\
\mathrm{MTk}+\mathrm{MX}+\mathrm{NX}+ \\
\mathrm{NV}\end{array}$ & $\begin{array}{c}\mathrm{PVA}+\mathrm{PV}+ \\
\mathrm{MTk}+\mathrm{MX}+\mathrm{NX}+ \\
\mathrm{NV}+\mathrm{CX}\end{array}$ & $\mathrm{CX}+\mathrm{RR}+\mathrm{RL}+\mathrm{AF}$ \\
\hline MNPcf & $\mathrm{LV}+\mathrm{LVA}$ & $\begin{array}{c}\mathrm{PVA}+\mathrm{PV}+ \\
\mathrm{MTk}+\mathrm{MX}+\mathrm{NX}+ \\
\mathrm{NV}\end{array}$ & $\begin{array}{c}\mathrm{PVA}+\mathrm{PV}+ \\
\mathrm{MTk}+\mathrm{MX}+\mathrm{NX}+ \\
\mathrm{NV}+\mathrm{CX}\end{array}$ & $\mathrm{CX}+\mathrm{RR}+\mathrm{RL}+\mathrm{AF}$ \\
\hline Lentes & $\mathrm{LV}+\mathrm{LVA}$ & MTk & $\mathrm{MTk}+\mathrm{MX}$ & $\begin{array}{c}\mathrm{MX}+\mathrm{CX}+ \\
+\mathrm{RR}+\mathrm{RL}+ \\
\mathrm{AF}\end{array}$ \\
\hline Curvatura & Linear & Convexa & Côncava & Côncava \\
\hline
\end{tabular}

(1) Domínio geológicos descritos por Freitas-Silva e Campos (1998): Grupo Paranoá: MNPppc (PsamoPelitoCarbonatada) Grupo Canastra: MNPccf (Clorita Carbonato Filito); MNPcf (Carbonato Filito) e Lentes Calcárias. Classes de Solos: LV - Latossolo Vermelho; LVA - Latossolo VermelhoAmarelo; CX - Cambissolo Háplico; RL - Neossolo Litólico; RR - Neossolo Regolítico; PVA Argissolo Vermelho-Amarelo; PV - Argissolo Vermelho; NV - Nitossolo Vermelho; MTk - Chernossolo Argilúvico; MX - Chernossolo Háplico; AF - Afloramentos Rochosos. 


\subsection{3 - Aplicação da lógica fuzzy no mapeamento digital com enfoque aos solos com horizonte B textural e B nítico}

\subsubsection{1 - Banco de Dados}

Os banco de dados utilizado no estudo foi composto pelo MDT - Modelo Digital de Terreno da microbacia do Ribeirão Salinas, DF, e pelos mapas derivados dele, mapa de altimetria, mapa de declividade e mapa de curvatura. Também foi utilizado o mapa temático de geologia da área de estudo (Freitas-Silva e Campos, 1998). O banco de dados também contempla as informações do modelo de distribuição de solos da microbacia do Ribeirão Salinas (relações pedomorfogeológicas) e dos perfis de solos representativos da ocorrência das classes de solos com horizonte B textural e B nítico descritos durante os trabalhos de campo ao longo de geo-topossequências representativas da distribuição desses solos na microbacia mapeada (Capítulo 1).

\subsubsection{2 - Inferência Fuzzy}

Segundo Câmara et al. (2001) na teoria dos conjuntos nebulosos existe um grau de pertinência de cada elemento a um determinado conjunto. O conjunto "Fuzzy" estabelece uma caracterização de classes, que por várias razões não tem ou não pode definir limites rígidos (bordas) entre classes. Essas classes definidas de maneira inexata são chamadas de conjunto "Fuzzy". Assim o grau de pertinência do conjunto "Fuzzy", geralmente representado por $\mu(x)$, é expresso em termos de uma escala que varia continuamente entre 0 e 1 , que reflete o grau de verdade de uma proposta ou hipótese (probabilístico).

Partindo dessa premissa e pelo fato de que esse é um modelo dirigido pelo conhecimento do analista (Souza Filho e Crosta, 2003) foram atribuídos pesos para cada classe dos atributos avaliados (geologia, declividade, curvatura e altimetria), em uma escala com valores de 0 a 1 , com a finalidade de identificar as classes de solos que apresentam horizonte B textural e B nítico na região da microbacia do Ribeirão Salinas.

As classes dos mapas de geologia, declividade, curvatura e altimetria foram reclassificadas com os devidos graus de pertinência (no intervalo de 0 a 1) e os mapas foram integrados no ArcGIS, por meio do módulo Spatial Analyst Tools, ferramenta 
Overlay $\rightarrow$ Fuzzy Overlay por meio do operador lógico Fuzzy AND, gerando, dessa maneira, um mapa de possibilidades fuzzy para cada classe de solo predeterminada.

Para combinar os mapas gerados de possibilidades fuzzy das classes de solos na etapa anterior foi necessário realizar a reclassificação dos mesmos, com finalidade de evitar ambiguidades, onde foi associada uma sequência ordenada de potências de 2 para cada mapa de possibilidades fuzzy (Nolasco-Carvalho, 2009). As classes onde foram atribuídos o valor 0 representam a ausência de ocorrência de classes de solos que apresentam horizonte B textural e B nítico, já as classes que receberam valores distintos correspondem às proporções em que esses solos podem ser formados.

Por fim foram gerados seis mapas de possibilidades fuzzy das classes de solos estudadas que combinados corresponderam ao mapa digital de solos com horizonte $\mathrm{B}$ textural e B nítico da microbacia do Ribeirão Salinas.

\subsection{4 - Validação do mapeamento digital de solos}

Para que um mapa digital de solos produzido tenha validade e aplicabilidade é necessário a realização da sua validação em campo ("verdade de campo"), com a análise de morfologia do solo, caracterização laboratorial e classificação das classes de solos mapeadas, com base em amostragens representativas e verificação dos limites das unidades de mapeamento, com o objetivo de verificar a precisão do mapa gerado (Silva, 2000).

A análise da exatidão do mapeamento foi realizada por meio do coeficiente Kappa de Cohen (Cohen, 1960), que é baseado na diferença entre concordância observada ("verdade de campo") e a chance de concordância entre os dados de referência do produto digital gerado (Congalton e Green, 1999).

O coeficiente Kappa tem seus valores distribuídos entre 0 e 1, onde o valor 1 representa a concordância máxima e quando multiplicado por 100, exibe a porcentagem da medida de exatidão do mapeamento (Ferreira, 2006). De acordo com Landis e Koch (1977), a avaliação por meio do coeficiente Kappa pode ser realizada com base nos valores apresentados na tabela 20. 
Tabela 20. Classificação dos valores do coeficiente Kappa, segundo Landis e Koch (1977).

\begin{tabular}{|c|c|}
\hline Coeficiente Kappa & Exatidão \\
\hline$<0$ & Péssima \\
\hline $0-0,2$ & Ruim \\
\hline $0,21-0,4$ & Razoável \\
\hline $0,41-0,6$ & Moderada/Boa \\
\hline $0,61-0,8$ & Muito Boa \\
\hline $0,81-1,0$ & Excelente \\
\hline
\end{tabular}

Para validação do mapa digital de solos foram obtidos e georreferenciados pontos amostrais (perfis completos e pontos de observação) dentro do limite da área da microbacia, por meio de GPS de Navegação Garmin. Os pontos foram obtidos de maneira aleatória, de forma a abranger toda a extensão da área mapeada, e em cada ponto foram identificadas as classes de solos pertencentes, para obtenção da "verdade de campo".

Entretanto, devido à grande dificuldade de acesso a algumas áreas da microbacia estudada, realizou-se a validação nessas regiões por meio da obtenção de pontos georreferenciados em fotografias aéreas ortorretificadas, em escala 1:10.000 (Codeplan, 2009), onde as classes de solos nos pontos selecionados foram identificadas com base no MDT elaborado e mapas derivados dele (altimetria, declividade, curvatura), além do mapa geológico, bem como no modelo de distribuição de solos (relações pedomorfogeológicas) estabelecido para a microbacia do Ribeirão Salinas, DF.

Posteriormente, foi gerada a matriz de erros também denominada de matriz de confusão. Neste tipo de registro os dados de referência geralmente são representados pelas colunas da matriz e são comparados com os dados classificados nos produtos digitais, representados pelas linhas da matriz. Os elementos da diagonal principal indicam o nível de concordância entre os dois conjuntos de dados (Congalton e Green, 1999).

A matriz de erros da área estudada foi gerada por meio de 100 pontos amostrais georreferenciados obtidos de maneira aleatória na região da microbacia, de forma a representar toda a extensão territorial da mesma

$\mathrm{Na}$ matriz de erros foram calculados a acurácia global (AG), acurácia do mapeador (AM), acurácia do usuário (AU) e coeficiente Kappa de Cohen (Kappa). 
A AG foi estimada com base no produto da soma das observações correspondentes entre o original e estimado pelo total de observações da matriz de forma percentual (Figueiredo et al., 2008).

A AU e AM foram calculadas dividindo-se o número de observações correspondentes entre o mapa original e o estimado pela soma de observações não correspondentes de cada classe de solo, expresso na forma percentual (Figueiredo et al., 2008).

A acurácia do usuário refere-se aos erros de inclusão ou omissão (Hord e Brooner, 1976; Rosenfield e Fitzptrik-Lins, 1986; Congalton,1991). Os erros de inclusão são relativos a todos os pontos atribuídos a uma determinada classe oriundos de erros de classificação das outras classes. Desta forma, a acurácia do usuário indica a probabilidade que uma categoria classificada (mapa/imagem) represente a mesma categoria no campo. A acurácia do mapeador leva em consideração os erros de exclusão ou omissão, onde não são atribuídos a determinada classe os erros de classificação das outras classes. Da mesma forma, a acurácia do mapador refere-se à probabilidade de determinada categoria ter sido corretamente classificada de acordo com os pontos de referência (Rosenfield et al. 1986; Story e Congalton, 1986).

O coeficiente Kappa de Cohen (Cohen, 1960) foi calculado segundo a seguinte equação:

$$
\kappa=\frac{\mathrm{Po}-\mathrm{Pe}}{1-\mathrm{Pe}}
$$

Equação 3

Onde $\mathrm{P}_{\mathrm{o}}$ para toda a matriz de erros é dado pela razão do somatório da diagonal principal ( $\sum$ Xii) pelo número total de observações $(\mathrm{N})$. $\mathrm{P}_{\mathrm{e}}$ é expresso pelo somatório do produto dos elementos das linhas e colunas marginais $\left(\sum \mathrm{Xi}+\mathrm{X}+\mathrm{i}\right)$ pelo número total de observações ao quadrado (Cohen, 1960).

\section{3 - RESULTADOS E DISCUSSÃO}

Por meio do modelo gerado de distribuição de solos da microbacia do Ribeirão Salinas, DF (relações pedomorfogeológicas), embasado na coleta de informações nos trabalhos de campo e da avaliação do mapa geológico e mapas derivados do Modelo Digital de Terreno - MDT, foi possível gerar uma tabela com os graus de pertinência para cada classe de atributos avaliados (geologia, altimetria, declividade e curvatura) 
(Tabela 21) com a finalidade de gerar mapas de possibilidade fuzzy para as classes de solos com horizonte B textural e B nítico em avaliação.

Tabela 21. Peso dos atributos avaliados para as classes Argissolo Vermelho-Amarelo, Argissolo Vermelho, Chernossolo Argilúvico, Nitossolo Vermelho, Nitossolo Háplico, Chernossolo Háplico.

\begin{tabular}{|c|c|c|c|c|c|c|c|}
\hline \multicolumn{8}{|c|}{ Argissolo Vermelho-Amarelo - PVA } \\
\hline Geologia & $\mathbf{P C}$ & Declividade (\%) & $\mathbf{P C}$ & Curvatura & $\mathbf{P C}$ & Altimetria (m) & $\mathbf{P C}$ \\
\hline MNPccf & 0,4 & $0-10$ & 0 & convexa & 0,9 & 750-100 & 1 \\
\hline MNPcf & 0,6 & $10-24$ & 0,8 & linear & 0 & & \\
\hline Lentes Calcárias & 0 & $24-45$ & 0,5 & côncava & 0,3 & & \\
\hline MNPppc & 0,9 & $>45$ & 0 & & & & \\
\hline \multicolumn{8}{|c|}{ Argissolo Vermelho - PV } \\
\hline Geologia & $\mathbf{P C}$ & Declividade (\%) & PC & Curvatura & $\mathbf{P C}$ & Altimetria (m) & $\mathbf{P C}$ \\
\hline MNPccf & 0,6 & $0-10$ & 0 & convexa & 1 & 750-100 m & 1 \\
\hline MNPcf & 0,5 & $10-24$ & 0,8 & linear & 0 & & \\
\hline Lentes Calcárias & 0,1 & $24-45$ & 0,2 & côncava & 0,2 & & \\
\hline MNPppc & 0,2 & $>45$ & 0 & & & & \\
\hline \multicolumn{8}{|c|}{ Chernossolo Argilúvico - MTk } \\
\hline Geologia & $\mathbf{P C}$ & Declividade (\%) & PC & Curvatura & $\mathbf{P C}$ & Altimetria (m) & PC \\
\hline MNPccf & 0,2 & $0-10$ & 0 & convexa & 1 & 750-100 m & 1 \\
\hline MNPcf & 0,3 & $10-24$ & 1 & linear & 0 & & \\
\hline Lentes Calcárias & 1 & $24-45$ & 0,2 & côncava & 0,1 & & \\
\hline MNPppc & 0 & $>45$ & 0 & & & & \\
\hline \multicolumn{8}{|c|}{ Chernossolo Háplico - MX } \\
\hline Geologia & $\mathbf{P C}$ & Declividade (\%) & $\mathbf{P C}$ & Curvatura & PC & Altimetria (m) & $\mathbf{P C}$ \\
\hline MNPccf & 0,8 & $0-10$ & 0 & convexa & 1 & 750-100 m & 1 \\
\hline MNPcf & 0,5 & $10-24$ & 1 & linear & 0 & & \\
\hline Lentes Calcárias & 0,1 & $24-45$ & 0,3 & côncava & 0,3 & & \\
\hline MNPppc & 0 & $>45$ & 0 & & & & \\
\hline \multicolumn{8}{|c|}{ Nitossolo Háplico - NX } \\
\hline Geologia & PC & Declividade (\%) & $\mathbf{P C}$ & Curvatura & $\mathbf{P C}$ & Altimetria (m) & $\mathbf{P C}$ \\
\hline MNPccf & 0,7 & $0-10$ & 0 & convexa & 1 & $750-100 \mathrm{~m}$ & 1 \\
\hline MNPcf & 0,8 & $10-24$ & 0,9 & linear & 0 & & \\
\hline Lentes Calcárias & 0 & $24-45$ & 0,3 & côncava & 0,2 & & \\
\hline MNPppc & 0,1 & $>45$ & 0 & & & & \\
\hline \multicolumn{8}{|c|}{ Nitossolo Vermelho - NV } \\
\hline Geologia & PC & Declividade (\%) & $\mathbf{P C}$ & Curvatura & $\mathbf{P C}$ & Altimetria (m) & $\mathbf{P C}$ \\
\hline MNPccf & 0,6 & $0-10$ & 0 & convexa & 1 & 750-100 m & 1 \\
\hline MNPcf & 0,4 & $10-24$ & 0,9 & linear & 0 & & \\
\hline Lentes Calcárias & 0,2 & $24-45$ & 0,2 & côncava & 0,2 & & \\
\hline MNPppc & 0,1 & $>45$ & 0 & & & & \\
\hline
\end{tabular}


Geologia descrita por Freitas-Silva e Campos (1998): Grupo Paranoá: MNPppc (Psamo-Pelito Carbonatada) Grupo Canastra: MNPccf (Clorita Carbonato Filito); MNPcf (Carbonato Filito) e Lentes Calcárias. $\mathrm{PC}=$ peso das classes.

As classes de solos que apresentam horizonte B textural e B nítico avaliadas foram: Argissolo Vermelho-Amarelo, Argissolo Vermelho, Nitossolo Háplico, Nitossolo Vermelho, Chernossolo Argilúvico e Chernossolo Háplico.

Em função do conhecimento prévio da área de estudo, optou-se pela atribuição dos pesos de maneira subjetiva, não se aplicando as funções de pertinência neste estudo.

\subsection{1 - Mapas de pertinência fuzzy}

Os mapas de pertinência fuzzy foram gerados no sofware ArcGIS, por meio da ferramenta Fuzzy Overlay, que sobrepôs as informações dos fatores de formação do solo selecionados neste estudo, ou seja: geologia e relevo (altimetria, declividade, curvatura) para gerar o mapa de solos para cada classe de solos com horizonte B textural e B nítico predeterminada. Dessa maneira, seis mapas de pertinência fuzzy (Figura 17) foram gerados, correspondendo às possibilidades de ocorrência das classes de solos: Argissolo Vermelho-Amarelo, Argissolo Vermelho, Chernossolo Argilúvico, Chernossolo Háplico, Nitossolo Háplico e Nitossolo Vermelho.

O operador lógico utilizado foi o Fuzzy AND, que segundo Silva (2003) define o menor membro que controla os conjuntos fuzzy, o que proporciona estimativas bastante conservadoras.

Nolasco-Carvalho et al. (2009) aplicaram o operador AND para gerar o mapa digital de solos de Mucugê (BA) na escala 1:100.000, verificando que este operador realiza uma seleção mais rigorosa de áreas mais propícias à ocorrência de determinada classe de solo.

No presente estudo foram realizados testes com os operadores Fuzzy AND (intersecção), Fuzzy OR (união), Fuzzy SUM (soma algébrica), Fuzzy PRODUCT (produto algébrico) e Fuzzy GAMA, porém optou-se pela aplicação do operador Fuzzy AND, uma vez que este detectou não somente unidades simples de mapeamento bem como as respectivas associações de classes de solos.

Após a integração dos mapas de possibilidades fuzzy foi realizada a reclassificação dos mesmos em potências ordenadas de 2 (Figura 17). Assim como 
verificado nos trabalhos de Nolasco-Carvalho et al. (2009) e Lima (2013) esse procedimento foi empregado com a intenção de evitar interpretações errôneas da distribuição dos solos com horizonte $\mathrm{B}$ textural e $\mathrm{B}$ nítico na região microbacia, uma vez que existem similaridades entre os mapas gerados.

Segundo Nolasco-Carvalho et al. (2009) esta técnica, denominada inferência média ponderada, aplicada para fusão de mapas de evidências de classes de solo, permite que as simultaneidades sejam expressas por valores que possam ser reconhecidos, avaliados e correlacionados à realidade local; trata-se de um artifício que evita resultados ambíguos, os quais podem conduzir a interpretações e a distribuição espacial incorretas dos solos na confecção do mapa digital de solos.
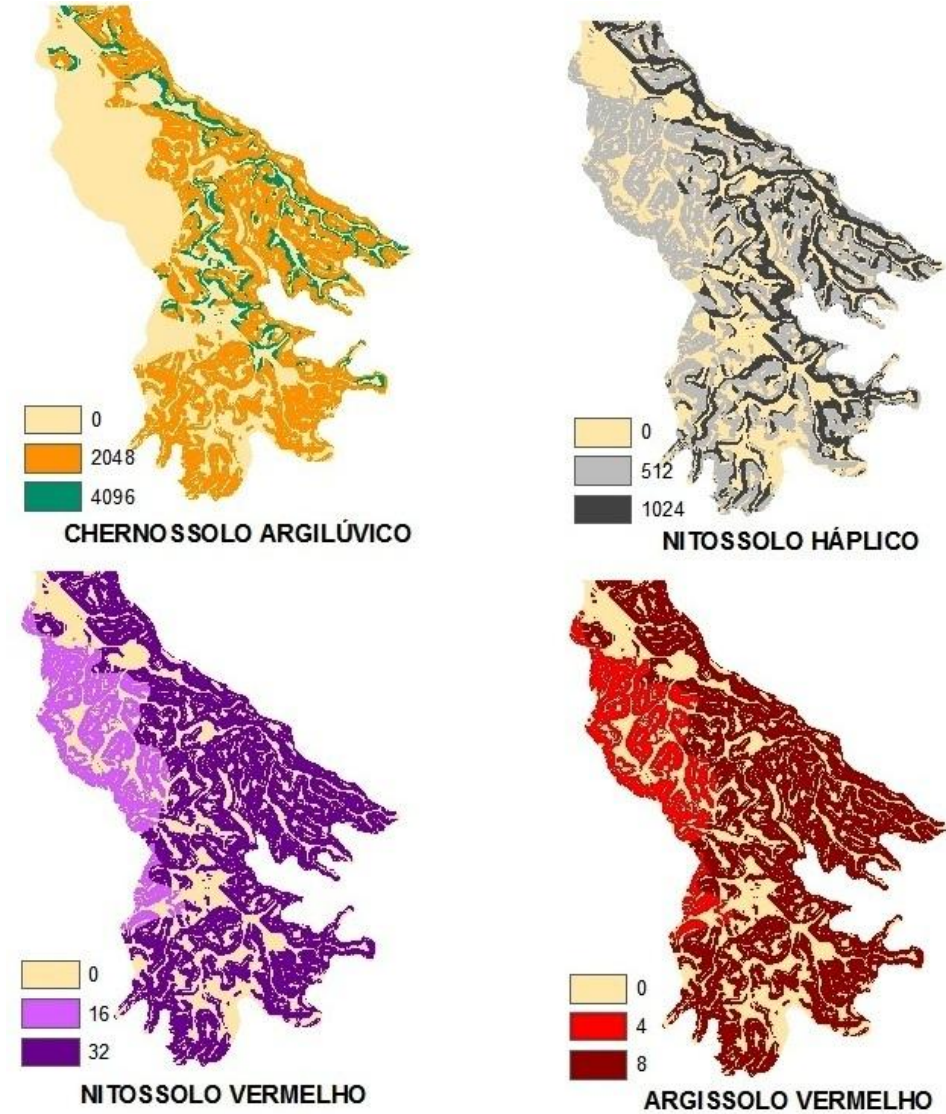

NITOSSOLO HÁPUCO
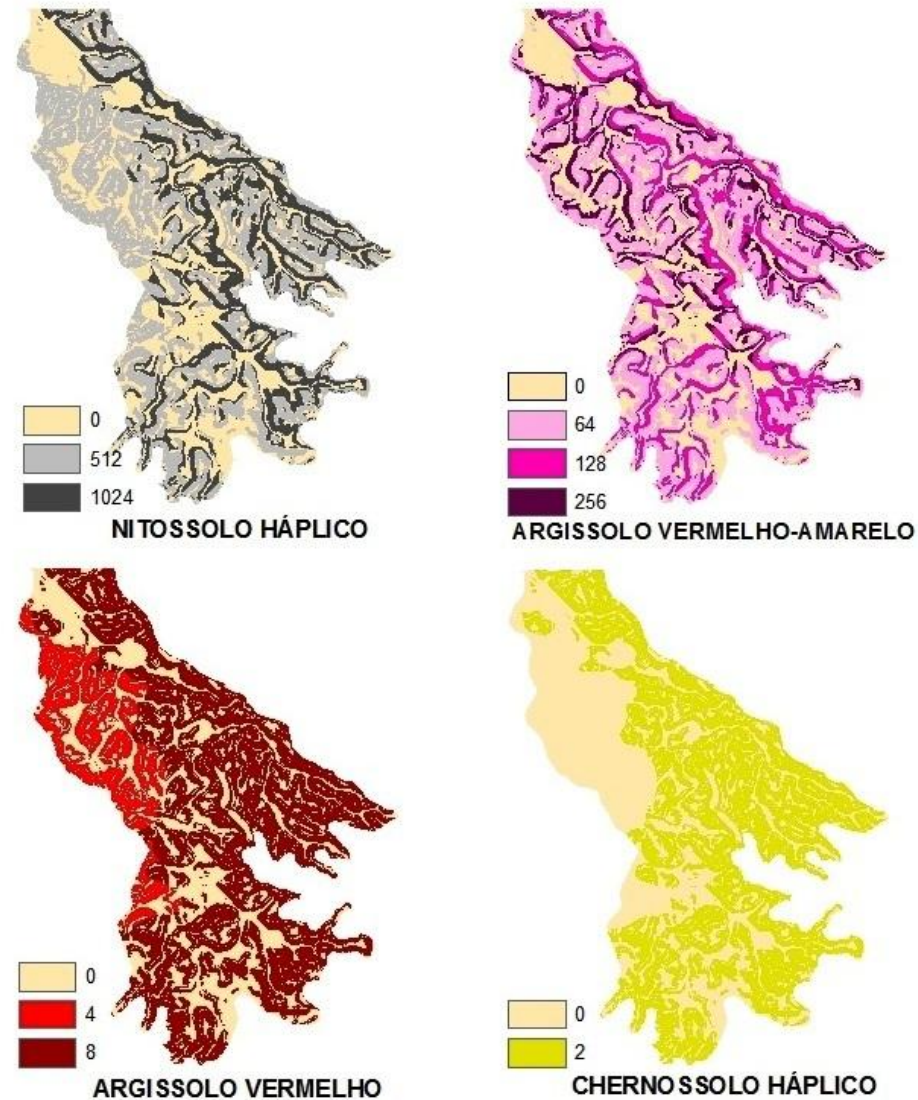

Figura 17. Mapas de pertinência fuzzy reclassificados em potências ordenadas de 2 das classes de solos predeterminadas da microbacia do Ribeirão Salinas, DF.

\subsection{2 - Mapa digital de solos e avaliação da exatidão do mapeamento}

O mapa digital de solos da microbacia do Ribeirão Salinas, DF (Figura 18) é o produto da combinação dos seis mapas de possibilidades fuzzy de cada classe de solos 
com horizonte B textural e B nítico de ocorrência na área estudada, apresentados na figura 17.

O mapa gerado apresenta a individualização dos solos com horizonte B textural e B nítico da microbacia estudada. Esses solos ocorrem preferencialmente em relevo convexo, em classes de declividades que variam de 10 a $24 \%$, podendo ocorrer em relevo côncavo em declividades de 24 a 45\%, em associação com Cambissolos Háplicos. Lacerda et al. (2009) observaram distribuição de solos com horizonte B textural e B nítico semelhante na região de Lavras (MG).

Os solos estudados ocorrem exclusivamente na Terceira Superfície Geomorfológica do Distrito Federal (Motta et al., 2002) sobre litologias do Grupo Paranoá e preferencialmente do Grupo Canastra.

No mapa digital de solos foi gerada uma classe que compreende as demais classes de solos que ocorrem na região da microbacia, tais como Latossolo Vermelho, Latossolo Vermelho-Amarelo, Cambissolo Háplico, Neossolo Regolítico, Neossolo Litólico e Afloramentos Rochosos, que não foram objeto de estudo deste trabalho.

No contexto da microbacia do Ribeirão Salinas, as classes de Argissolos, Nitossolos e Chernossolos apresentam características muito similares com relação à sua distribuição e ocorrência na paisagem, além de características químicas, físicas e mineralógicas semelhantes, por isso, no mapa gerado essas classes foram agrupadas em associações de solos, devido a dificuldade de se estabelecer unidades simples de mapeamento, com exceção das unidades PVA e MTk, que foram mais facilmente detectáveis em função da primeira ocorrer preferencialmente nas porções mais côncavas da paisagem (Martins et al., 2004) a partir de litologias do Grupo Paranoá, mais empobrecidas em elementos nutrientes minerais, e a segunda se desenvolver preferencialmente sobre lentes calcárias e litologias associadas do Grupo Canastra.

Segundo Lima (2013) apesar de a lógica fuzzy fornecer a variação gradual da possibilidade de ocorrência de determinada classe de solo, existe dificuldade em representar essa variação no mapa final de classes de solos, que normalmente são apresentados com limites rígidos, assim como nos mapas tradicionais.

Contudo, muitos trabalhos têm demonstrado a capacidade da lógica fuzzy na modelagem de fenômenos espaciais. McBratney e Odeh (1997) apresentaram algumas aplicações da teoria dos conjuntos fuzzy nas ciências dos solos, tais como: mapeamento e classificação numérica; avaliação do uso; modelagem e simulação de processos físicos; variograma e krigagem fuzzy de variáveis; análise de imagem digital; medidas 
de fenômenos definidos de forma imprecisa e índice de qualidade dos solos. Os autores ainda ressaltam que muitos outros conceitos e sistemas de solos podem ser modelados, simulados e copiados com a ajuda dos sistemas fuzzy.

No mapa digital gerado de solos da microbacia do Ribeirão Salinas (Figura 18), as associações de solos com horizonte B textural e B nítico foram classificadas até o $3^{\circ}$ nível categórico do Sistema Brasileiro de Classificação de Solos (Embrapa, 2013).

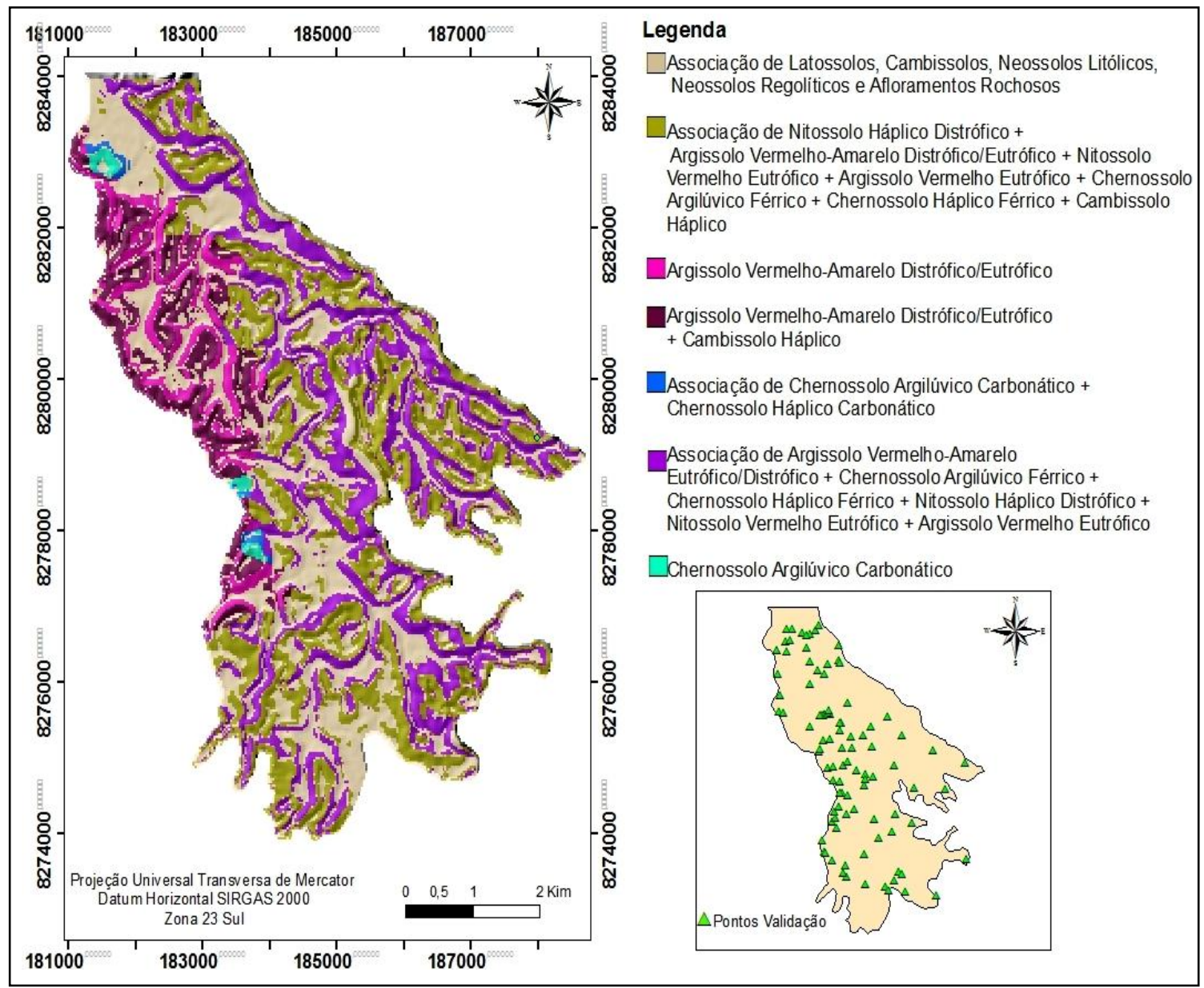

Figura 18. Mapa digital de solos com horizonte B textural e B nítico na microbacia do Ribeirão Salinas, DF.

Com base na matriz de erros (Tabela 22) foi calculada a acurácia global e o índice Kappa do mapeamento, o valor de AG obtido foi de 0,77 ou $77 \%$, e o índice Kappa estimado para o mapeamento foi de 0,7135 ou $71,35 \%$, o desempenho da classificação foi considerado muito bom segundo a classificação proposta por Landis e Koch (1977). 
Tabela 22. Matriz de erros entre a verdade de campo e o mapa digital de solos com horizonte B textural e B nítico da microbacia do Ribeirão Salinas, DF.

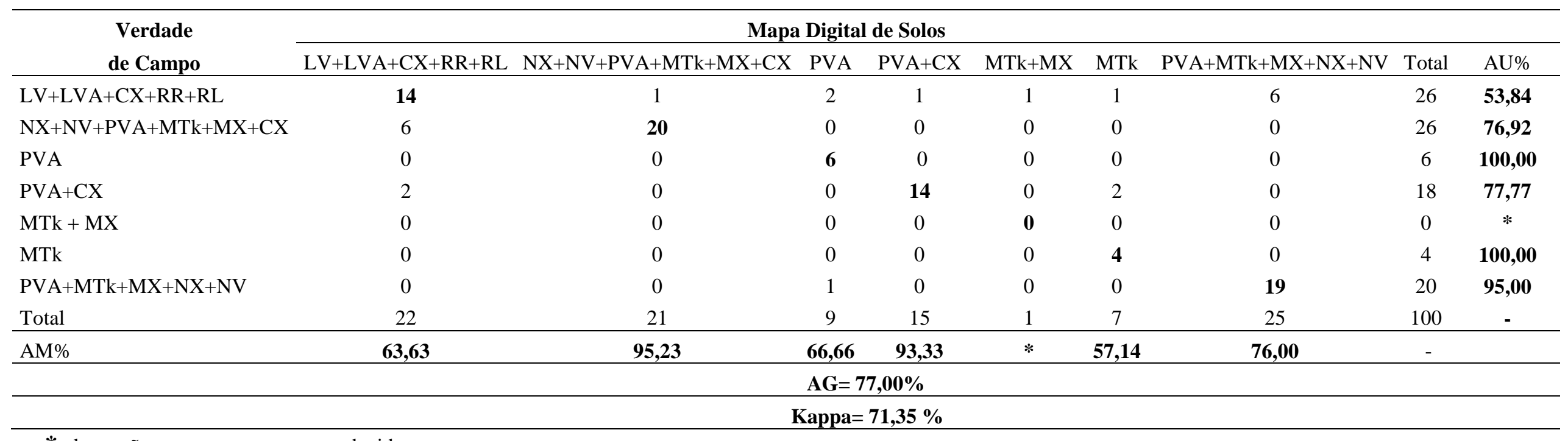

\footnotetext{
* classe não ocorrente no mapa produzido.
} 
Lima (2013) obteve valores menos elevados de acurácia global e coeficiente Kappa, $63,64 \%$ e 55,41\%, respectivamente, aplicando os métodos semi-automático e lógica fuzzy para o mapeamento de solos da Bacia do Sarandi, DF.

Outros autores obtiveram valores distintos em mapeamentos digitais de solos de AG e índice Kappa empregando as demais técnicas de mapeamento digital de solos: Figueiredo et al. (2008) obtiveram AG de 58\% e Kappa de 38\% utilizando regressões logísticas múltiplas no Planalto Médio do Rio Grande do Sul. Crivelenti et al. (2009) utilizaram árvores de decisão no mapeamento digital de solos da folha topográfica de Dois Córregos (SP) e observaram Kappa de 43\%. Arruda et al. (2013) observaram valores mais elevados de AG e índice Kappa, empregando redes neurais artificiais em uma área localizada no município de Barra Bonita (SP), ou seja: 77,5\% e 74,5\%, respectivamente. Valladares (2012) obteve índice Kappa de $41 \%$ empregando geoestatística no mapeamento digital de solos dos tabuleiros costeiros no litoral norte do estado do Ceará. Chagas (2010) determinou valores do índice Kappa de 73,81\%, utilizando redes neurais artificiais em uma bacia hidrográfica no noroeste do estado do Rio de Janeiro.

Segundo Ten Caten et al. (2012) o valor médio do índice Kappa entre os estudos realizados no país é de 0,48 . Esse valor é similar aos valores reportados na literatura internacional como em Hengl e Rossiter (2003), de 0,58 em locais montanhosos e de 0,39 para áreas planas.

Em conformidade com Figueiredo et al. (2008), Arruda et al. (2013), Neumann (2012) e Lima (2013) a acurácia global foi superior ao coeficiente Kappa. Esse fato é observado em função da acurácia global considerar apenas a diagonal principal da matriz de erros, ignorando os demais elementos da matriz (Brites et al., 1996), ou seja, a AG considera apenas a proporção de observações corretamente classificadas em relação ao número total de observações (Silva et al., 2013).

Por meio da matriz de erros (Tabela 22) também foram calculadas a acurácia do mapeador e a acurácia do usuário para as associações de solos estabelecidas. Assim, verificou-se que as unidades $\mathrm{NX}+\mathrm{NV}+\mathrm{PVA}+\mathrm{MTk}+\mathrm{MX}+\mathrm{CX}, \mathrm{PVA}+\mathrm{CX}$ e $\mathrm{PVA}+\mathrm{MTk}+\mathrm{MX}+\mathrm{NX}+\mathrm{NV}$ apresentaram os melhores resultados, com AM 95,23\%, 93,33\% e 76,00, respectivamente, refletindo a elevada probabilidade dessas associações de solos terem sido corretamente classificadas de acordo com os pontos de referência (Rosenfield e Fitzptrik-Lins, 1986; Story e Congalton, 1986). 
Com relação a acurácia do usuário, todas as unidades mapeadas apresentaram elevados valores de AU, a exemplo das unidades de mapeamento MTk e PVA que apresentaram AU de 100\%, indicando a probabilidade em 100\% dessas classes de solos representarem a mesma classe de solo no campo (Rosenfield e Fitzptrik-Lins, 1986; Story e Congalton, 1986) Apenas a associação de LV+LVA+CX+RR+RL apresentou valor de AU baixo, 53, 84\%, porém essa unidade de mapeamento não foi objeto de estudo neste trabalho.

Os elevados valores de acurácia obtidos neste estudo podem ser justificados pelo modelo elaborado de distribuição de solos na paisagem da microbacia estudada, cujas classes de solos com horizonte B textural e B nítico apresentam condições específicas bem definidas de formação e ocorrência em relação aos atributos do relevo e material de origem associado. A região também favorece a elaboração de modelos pedogenéticos, pois apresenta relevo montanhoso em processo de dissecação, condição que proporciona o desenvolvimento de solos "in situ". Estas condições favorecem o mapeamento digital dos solos, por isso os valores de acurácia são mais altos em relação aos mapeamentos digitais de solos em áreas planas, onde geralmente ocorre contribuição de material das encostas (coluvionamento) (Hengl e Rossiter, 2003). Essa afirmativa é corroborada por Chagas (2006) que obteve índices Kappa superiores a 0,80 e de acurácia global superiores a $80 \%$, em média com diferentes arquiteturas de redes neurais em uma bacia hidrográfica no domínio de Mar dos Morros.

Outro fator que possivelmente contribuiu para os valores de acurácia obtidos nesse estudo foi o agrupamento das unidades de mapeamento em associações de solos, o que possibilitou maior concordância entre os pontos observados no campo e o mapa predito.

Nolasco-Carvalho et al. (2009) e Silva et al. (2011) empregaram a lógica fuzzy no mapeamento digital de solos e utilizaram mapas convencionais de solos preexistentes para comparar a eficiência do mapeamento. Para Figueiredo (2006) estas metodologias de estatísticas de mapas em que se comparam mapas de solos tradicionais com estimados são pouco utilizadas, em parte por acreditar-se que o modelo deve adequar-se mais a realidade de campo do que ao mapa tradicional a que pretende representar e que possui, invariavelmente certo grau de erro que lhe é inerente, e em parte porque os valores de AG e Kappa apresentam-se sempre relativamente baixos ou omitidos.

Segundo Ten Caten et al. (2012) entre os estudos de MDS no país, em apenas três casos foi avaliada a acurácia do mapeamento com dados de campo (Chagas, 2010; 
Ten Caten, 2011; Carvalho Junior, 2011). Predomina entre os estudos apenas a avaliação do potencial de reprodução do mapa original a partir dos modelos preditivos, que pode não ser uma abordagem eficaz para indicar a qualidade do mapa de solos gerado, dado que o mapa original pode apresentar erros.

Ainda segundo estes autores a comparação do mapa gerado pela metodologia automatizada com aquele obtido pela metodologia convencional apenas indica a capacidade de reprodução deste último pelo modelo preditivo. A checagem do mapa predito com informações de campo deve ser o verdadeiro indicador de qualidade a ser empregado.

Nesse sentido, evitou-se realizar a comparação visual entre o mapa digital de solos elaborado (Figura 15) e o mapa de solos tradicional (Embrapa, 1978), uma vez que este encontra-se em escala 1:100.000 e o produto gerado neste estudo tem escala compatível com levantamentos de semidetalhe $\leq 1: 20.000$.

\section{4 - CONCLUSÕES}

1. A utilização dos atributos do terreno (curvatura, declividade e altimetria), associados aos materiais de origem distintos em uma abordagem fuzzy, proporcionaram o mapeamento digital de solos na microbacia do Ribeirão Salinas, com enfoque para as classes de solos que apresentam horizonte B textural e Bt (nítico).

2. O principal atributo que influencia a variação das classes de solos que apresentam horizonte B textural e B nítico na porção noroeste do Distrito Federal é a diferenciação composicional das litologias do Grupo Canastra.

3. Os mapeamentos digitais de solos são eficientes e compatíveis com a realidade quando associados a trabalhos de campo, com caracterização e classificação dos solos representativos, além da observação da distribuição destes na paisagem.

4. A validação do mapa digital de solos gerado por meio de pontos de observação no campo foi considerada muito boa mediante aplicação do índice Kappa. 


\section{RECOMENDAÇÕES}

Aperfeiçoar o mapa geológico disponível do Distrito Federal, para uma escala com melhor refinamento das unidades geológicas.

Gerar um banco de dados com as informações referentes às características morfológicas, físicas, químicas, mineralógicas e geoquímicas das classes de solos que apresentam horizonte B textural e B nítico.

Extrapolar o modelo de distribuição de solos da área de referência para áreas adjacentes do Planalto Central Brasileiro.

Por meio das informações produzidas no mapa digital de solos realizar estudos pedológicos diversos, tais como uso e ocupação das terras, aptidão agrícola das terras, gestão ambiental, entre outros.

\section{5 - REFERÊNCIAS BIBLIOGRÁFICAS}

ARRUDA, G. P.; DEMATTÊ, J. A. M.; CHAGAS, C. S. Mapeamento Digital de Solos por Redes Neurais Artificiais com base na relação solo-paisagem. Revista Brasileira de Ciência do Solo, v.37, p. 327-338, 2013.

BARBOSA, I. O. Distribuição dos solos nas chapadas elevadas do Distrito Federal, com emprego de geoprocessamento. 2007. 125p. Dissertação (Mestrado). Faculdade de Agronomia e Medicina Veterinária, Universidade de Brasília, Brasília. 2007.

BARBOSA, I. O.; LACERDA, M. P. C.; BILICH, M. R. Relações pedomorfogeológicas nas Chapadas Elevadas do Distrito Federal. Revista Brasileira de Ciência do Solo, v.33, n.5, p.1373-1383, 2009.

BRITES, R. S.; SOARES, V. P.; RIBEIRO, C. A. A. S. Comparação de desempenho entre três índices de exatidão aplicados a classificação de imagens orbitais. In: Simpósio Brasileiro de Sensoriamento Remoto, Salvador, 8, 1996. Anais... Salvador, INPE, 1996.

CARVALHO JUNIOR, W. Digital soilscape mapping of tropical hillslope areas by neural networks. Scientia Agricola, v.68, n.6, p.691-696, 2011.

CÂMARA, G.; MOREIRA, F. R.; BARBOSA, C.; FILHO, R. A.; BONISCH, S. "Técnicas de Inferência Geográfica" in Introdução à Ciência da Geoinformação Org. por Câmara, G.; Davis, C.; Monteiro, A. M. V, São José 
dos Campos, Instituto Nacional de Pesquisas Espaciais (INPE). Cap. 9, p. 2-48, 2001.

CHAGAS, C.S. Mapeamento digital de solos por correlação ambiental e redes neurais em uma bacia hidrográfica no domínio de mar de morros. 2006. 223p. Universidade Federal de Viçosa, Viçosa, MG. 2006.

CHAGAS, C. da S. Atributos topográficos e dados do Landsat7 no mapeamento digital de solos com uso de redes neurais. Pesquisa Agropecuária Brasileira, v.45, n.5, p.497-507, 2010.

CHAGAS, C.S.; CARVALHO JÚNIOR, W.; BHERING, S.B. Integração de dados dos quickbirde atributos do terreno no mapeamento digital de solos por redes neurais artificiais. Revista Brasileira de Ciência do Solo, v.35, p.693-704, 2011.

CODEPLAN. Companhia de Planejamento do Distrito Federal. Atlas do Distrito Federal. Brasília, CODEPLAN, 1984.

CODEPLAN/SICAD. Sistema Cartográfico do Distrito Federal. Brasília, CODEPLAN, 1991.

CODEPLAN. Companhia de Planejamento do Distrito Federal. GeoServiço. 2009. Disponível em: 〈http://ortofoto.mapa.codeplan.df.gov.br/demo/tms >. Acesso em: 02/02/2015.

COELHO, F. F. Comparação de métodos de mapeamento digital de solos através de variáveis geomorfométricas e Sistema de Informações Geográficas. 95p. 2010. Dissertação (Mestrado). Centro Estadual de Pesquisas em Sensoriamento Remoto e Meteorologia, Universidade Federal do Rio Grande do Sul, Porto Alegre. 2010.

COHEN, J. A coefficient of agreement for nominal scales. Educ. Psychol. Measur., v.20, p.37-46, 1960.

CONGALTON, R. G. A Review of Assessing the Accuracy of Classifications of Remotely Sensed Data. Remote Sensing of Environment, v.37, n.1, p.35-46, 1991.

CONGALTON, R. G.; GREEN, K. Assessing the accuracy of remotely sensed data: principles and practices. New York: Lewis Publishers, 1999. $136 \mathrm{p}$.

CRIVELENTI, R.C.; COELHO, R. M.; ADAMI, S. F.; ROBSON, S.; OLIVEIRA, M. Mineração de dados para a inferência de relações solo-paisagem em mapeamentos digitais de solo. Revista Agropecuária Brasileira, v.44, n.12, p.1707-1715, 2009. 
DEMATTÊ, J. A. M.; GENÚ, A. M.; FIORIO, P. R.; ORTIZ, J. L.; MAZZA, J. A.; LEONARDO, H. C. L. Comparação entre mapas de solos obtidos por sensoriamento remoto espectral e pelo método convencional. Pesquisa Agropecuária Brasileira, v.39, n.12, 2004.

EMBRAPA - Empresa Brasileira de Pesquisa Agropecuária - Serviço Nacional de Levantamento e Conservação de solos. Boletim Técnico $n^{\circ} 53$. Levantamento de Reconhecimento dos solos do Distrito Federal, Rio de Janeiro, Embrapa, 1978. 466p.

EMBRAPA - Empresa Brasileira de Pesquisa Agropecuária. Centro Nacional de Pesquisas de Solos. Sistema Brasileiro de Classificação de Solos. 3. ed. Brasília, DF, Embrapa Produção de Informação, 2013. 412 p.

FARIAS, M. F. R.. Integração de parâmetros morfométricos e interpretação de imagens orbitais para o auxílio no mapeamento de solos no Parque Nacional de Brasília. 2008. 136p. Dissertação (Mestrado). Universidade de Brasília/GEA, Brasília. 2008.

FERREIRA, C. S. Avaliação temporal do uso e ocupação das terras na bacia do Rio São Bartolomeu, DF. 2006, 120p. Dissertação (Mestrado). Faculdade de Agronomia e Medicina Veterinária, Universidade de Brasília, Brasília. 2006.

FIGUEIREDO, S. R. Mapeamento supervisionado de solos através do uso de regressões logísticas múltiplas e sistema de informações geográficas. 2006. 104p. Dissertação (Mestrado). Universidade Federal do Rio Grande do Sul, Porto Alegre. 2006.

FIGUEIREDO, S. R.; GIASSON, E.; TORNQUIST, C. G.; NASCIMENTO, P. C. Uso de regressões logísticas múltiplas para mapeamento digital de solos no Planalto Médio do RS. Revista Brasileira de Ciência do Solo, v.32, p.2779-2785, 2008, Número Especial.

FREITAS-SILVA, F. H.; CAMPOS, J. E. G. Geologia do Distrito Federal. In: CAMPOS, J. E. G.; FREITAS-SILVA, F. H., coords. Inventário hidrogeológico e dos recursos hídricos superficiais do Distrito Federal. Brasília, SEMATECIEMA-MMA-SRH, 1998.CD-ROM.

GIASSON, E.; SARMENTO, E. C.; WEBER, E.; FLORES, C. A.; HASENACK, H. Decision trees for digital soil mapping on subtropical basaltics teeplands. Scientia Agricola, v.68, n.2, p.167-174, 2011. 
GUIMARÃES, R. F. Utilização de um Modelo de Previsão de Áreas Suscetíveis à Escorregamentos Rasos com Controle Topográfico: Adequação e Calibração em Duas Bacias de Drenagem. 2000. 126p. Tese (Doutorado). Universidade Federal do Rio de Janeiro, Rio de Janeiro. 2000.

HENGL, T.; ROSSITER, D. G. Supervised landform classification to enhance and replace photo-interpretation in semi-detailed soil survey. Soil Science Sciety of America Journal, v.67, p.1810-1822, 2003.

HORD, R. M.; BROONER, W. Land Use Map-Accuracy Criteria. Photogrammetric Engineering and Remote Sensing, v.42, n.5, p. 671- 677, 1976.

JÚNIOR, B. S. G.; MAGAlhãeS, I. A. L.; FREITAS, C. A. A.; CECÍliO, R. A. Análise de técnicas de interpolação para espacialização da precipitação pluvial na bacia do rio Itapemirim (ES). Ambiência, v.8, n.1, p.61-71, 2012.

KRAEMER G. B. Variabilidade espacial dos atributos do solo na delimitação das unidades de mapeamento. 87p. Dissertação (Mestrado). Universidade Federal do Paraná, Curitiba. 2007.

LACERDA, M. P. C.; QUÉMENÉUR, J. J. G.; ANDRADE, H.; ALVES, H. M. R.; VIEIRA, T. G. C. Mapeamento preliminar de solos com horizonte B textural e B nítico na região de Lavras, MG. Ciência e Agrotecnologia, Lavras, v.33, n.3, p. 788-795, 2009.

LAGACHERIE, P.; McBRATNEY, A. B. Spatial soil information systems and spatial soil inference systems: perspectives for digital soil mapping. In: Digital Soil Mapping: An Introductory Perspective. Montpellier and Sydney, p. 1-3, 2007.

LANDIS, J.; KOCH, G. G. The measurements of observer agreement for categorical data. Biometrics, v.33, n.3, p.159-179, 1977.

LIMA, L. A. S. Aplicação dos métodos semi-automático e lógica fuzzy para o mapeamento de solos da bacia do Sarandi. 2013. 124 p. Dissertação (Mestrado). Insituto de Geociências, Universidade de Brasília, Brasília. 2013.

LÓPEZ, L. R. Pedologia quantitativa: espectrometria VIS-NIR-SWIR e mapeamento digital de solos. 2009. 171 p. Dissertação (Mestrado). Escola Superior de Agricultura Luiz de Queiroz, Piracicaba. 2009.

LOSS, A.; CHAVES, A. C.; BERNINI; T. A.; COUTO, W. H. do; MIGUEL, D. L.;FRANCELINO, M. R.; ANJOS, L. H. C. dos. Aplicação de modelo digital de elevação para o levantamento de solos da microbacia do rio Bengala, Cachoeiras 
de Macacu, RJ, Brasil. Revista de Ciencia y Tecnología da América, Interciência, v.36, n.2, p. 121-127, 2011.

MARTINS, E. S.; BAPTISTA, G. M. M. Compartimentação geomorfológica e sistemas morfodinâmicos do Distrito Federal. In: Inventário hidrogeológicos e dos recursos hídricos superficiais do Distrito Federal. Brasília, IEMA/SEMATEC/UnB, v.1, p.89-137, 1998.

MARTINS, E. S.; REATTO, A.; CARVALHO JR, O. A.; GUIMARÃES, R. F. Evolução Geomorfológica do Distrito Federal. Planaltina, DF: Embrapa Cerrados, 2004. 57 p. - Documentos/Embrapa Cerrados, ISSN 1517-5111; n. 122 .

MENDONÇA-SANTOS M. L.; SANTOS H. G. dos. Mapeamento Digital de Classes e Atributos de Solos métodos paradigmas e novas técnicas. Rio de Janeiro, RJ. 2003 (Embrapa Solos. Documentos, 55). Disponível em: <http://www.cnps.embrapa.br>. Acesso em: 25/11/2014.

McBRATNEY, A.B.; ODEH, I.O. Application of fuzzy sets in soil science: fuzzy logic, fuzzy measurements and fuzzy decisions. Geoderma, v.77, p. 85-113, 1997.

McBRATNEY, A. B.; ODEH, I. O. A.; BISHOP, T. F. A..; DUNBAR, M. S.; SHATAR, T.M. An overview of pedometric techniques for use in soil survey. Geoderma, Amsterdam, v.97, n.3-4, p.293-327, 2000.

McBRATNEY, A. B.; SANTOS, M. L. M.; MINASNY, B.On digital soil mapping. Geoderma. Amsterdam, v.117, p.3-52, 2003.

MOTTA, P. E. F. DA; CARVALHO FILHO, A.; KER, J.; PEREIRA, N.; CARVALHO JUNIOR, W.; BLANCANEAUX, P. Relações solo-superfície geomórfica e evolução da paisagem em uma área do Planalto Central Brasileiro. Pesquisa Agropecuária Brasileira. Brasília, v.37, n.6, p.869-878, 2002

NEUMANN, M. R. B. Mapeamento Digital de Solos, no Distrito Federal. 2012, 110p. Tese (Doutorado). Instituto de Geociências, Universidade de Brasília, Brasília. 2012.

NOLASCO-CARVALHO, C. C.; FRANCA-ROCHA, W.; UCHA, J. M. Mapa digital de solos: uma proposta metodológica usando inferência fuzzy. Revista Brasileira de Engenharia Agrícola e Ambiental [online]. 2009, v.13, n.1, ISSN1415-4366. 
NOVAES PINTO, M. Caracterização Geomorfológica do Distrito Federal. In: NOVAES, M.P. (Org.) - Cerrado - Caracterização, Ocupação e Perspectivas. Brasília, Editora Universidade de Brasília, 1994, p. 285-320.

PENTEADO, O.M.M. Tipos de concreção ferruginosa nos compartimentos geomorfológicos do Planalto de Brasília. Not. Geom., v.16. p.39-53, 1976.

REATTO, A.; CORREIA, MARTINS, E. S.; FARIAS, M. F. R.; SILVA, A. V.; SPERA, S. T. Levantamento de Reconhecimento de Alta Intensidade dos solo da APA de Cafuringa - DF, escala 1:100.000. Planaltina: Embrapa Cerrados, 2002.

REATtO, A.; CORREIA, MARTINS, E. S.; FARIAS, M. F. R.; SIllVA, A. V. Relação entre Classes de Solos e as Fitofisionomias da Área de Preservação Ambiental - APA de Cafuringa, escala 1:100.000. Planaltina: Embrapa Cerrados, 2002.

ROSENFIELD, G. H.; FITZPTRIK-LINS, K. A Coefficent of Agreement as Measure of Thematic Classification Accuracy. Photogrammetric Engineering and Remote Sensing, v.52, n.2, p.223-227, 1986.

SANCHEZ, P.A. Digital soil map of the world. Science, v.325, p.680-681, 2009. Disponível em: <http://www.sciencemag.org/content/325/5941/680.full.pdf> Acesso em: 12/10/2014. doi: 10.1126/science.1175084.

SARMENTO, E. C. Comparação entre quatro algoritmos de aprendizagem de máquina no mapeamento digital de solos no Vale dos Vinhedos. 2010. 109p. Dissertação (Mestrado). Universidade Federal do Rio Grande do Sul, Rio Grande do Sul. 2010.

SEMARH - Secretaria de Meio Ambiente e Recursos Hídricos do Distrito Federal. Geomorfologia da APA de Cafuringa. 2006. Site: http://www.semarh.df.gov.br/semarh/site/cafuringa/Sec02/Frameset_cap2_4.ht. Acesso em: 15/01/2014.

SILVA, H.V. 2003. Utilização de Lógica Nebulosa na Detecção de Vazamentos em Dutos. Dissertação (Mestrado). Universidade Estadual de Campinas, Faculdade de Engenharia Mecânica, Campinas, 2003.

SILVA, R. R.; CANDEIAS, A. L. B.; ARAÚJO FILHO, J. C. Utilização da Lógica Fuzzy para mapeamento de solos do município de Petrolândia - PE. In: Simpósio Brasileiro de Sensoriamento Remoto, Curitiba, 15, 2011. Anais... Curitiba, INPE, 2011, p.568-575. 
SILVA, C. C.; COELHO, R. M.; OLIVEIRA, S. R. M.; ADAMI, S. F. Mapeamento pedológico digital da Folha Botucatu (SF-22-Z-B-VI-3): Treinamento de dados em mapa tradicional e validação de campo. Revista Brasileira de Ciência do Solo, v.37, p.846-857, 2013.

SOUSA JUNIOR, J. G. A.; DEMATTÊ, J. A. M. Modelo Digital de Elevação na caracterização de solos desenvolvidos e basalto e material arenítico. Revista Brasileira de Ciência do Solo, n.32, p.449-456, 2008.

SOUZA FILHO, C. R.; CROSTA, A. P. Geotecnologias aplicadas à geologia. Revista Brasileira de Geociências, v.33, p.1-4, 2003.

STORY, M.; CONGALTON, R. Accuracy Assessment: a User's Perspective. Photogrametric Engineering and Remote Sensing, v.52, n.3, p.379-399, 1986.

TEN CATEN, A. Extrapolação das relações solo-paisagem a partir de uma área de referência. Ciência Rural, v.41, n.5, p. 812-816, 2011.

TEN CATEN, A.; DALMOLIN, R. S. D.; MENDONÇA-SANTOS, M. L.; GIASSON, E. Mapeamento digital de classes de solos: características da abordagem brasileira. Ciência Rural, v.42, n.11, 2012.

VALLADARES, G. S. Geoestatística no mapeamento digital de solos dos tabuleiros costeiros no litoral norte do Estado do Ceará. Revista Equador, v. 1, n. 1, p. 2643, 2012. 


\section{ANEXO 1 \\ DESCRIÇÃO DO PERFIL DE NITOSSOLO HÁPLICO Distrófico úmbrico}

PERFIL $N^{\circ}-01$

DATA: $25 / 05 / 2012$

CLASSIFICAÇÃO - NITOSSOLO HÁPLICO Distrófico textura argilosa A proeminente.

LOCALIZAÇÃO, MUNICÍPIO, ESTADO E COORDENADAS - Estrada do Catingueiro, próximo ao Ribeirão Água Doce e próximo a DF - 205, UTM 185513 S (fuso 23) $8277030 \mathrm{~W}$ (fuso 23).

SITUAÇÃO, DECLIVE E COBERTURA VEGETAL SOBRE O PERFIL - Descrito e coletado em perfil de estrada, declividade $4 \%$,sob vegetação nativa de Floresta.

ALTITUDE - $877 \mathrm{~m}$

LITOLOGIA - Clorita Carbonato Filito.

FORMAÇÃO GEOLÓGICA - Grupo Canastra, Unidade Clorita Carbonato Filito.

CRONOLOGIA - Meso/Neoproterozóico

MATERIAL ORIGINÁRIO - Clorita Carbonato Filito.

PEDREGOSIDADE - Pedregoso

ROCHOSIDADE - Rochoso

RELEVO LOCAL - Plano

RELEVO REGIONAL - Plano a Montanhoso

EROSÃO - Em sulco.

DRENAGEM - Bem drenado.

VEGETAÇÃO PRIMÁRIA - Floresta Tropical Subcaducifólia

USO ATUAL - Vegetação nativa

CLIMA - Tropical de savana, Cwa da classificação de Koppen

DESCRITO E COLETADO POR - Rosana Quirino de Souza 


\section{DESCRIÇÃO DO PERFIL DE CHERNOSSOLO ARGILÚVICO Férrico típico}

PERFIL N ${ }^{\circ}-02$

DATA: $25 / 05 / 2012$

CLASSIFICAÇÃO - CHERNOSSOLO ARGILÚVICO Carbonático argila de alta atividade fase floresta tropical relevo forte ondulado.

LOCALIZAÇÃO, MUNICÍPIO, ESTADO E COORDENADAS - Estrada do Catingueiro, próximo ao Córrego Barreirão e próximo a DF - 205, 184508 S (fuso 23) $8278467 \mathrm{~W}$ (fuso 23)

SITUAÇÃO, DECLIVE E COBERTURA VEGETAL SOBRE O PERFIL - Descrito e coletado em perfil de estrada, declividade $17 \%$, sob vegetação nativa de Floresta.

ALTITUDE - $877 \mathrm{~m}$

LITOLOGIA - Carbonato Filito.

FORMAÇÃO GEOLÓGICA - Grupo Canastra, Unidade Carbonato Filito.

CRONOLOGIA - Meso/Neoproterozóico

MATERIAL ORIGINÁRIO - Carbonato Filito.

PEDREGOSIDADE - Não pedregoso

ROCHOSIDADE - Rochoso

RELEVO LOCAL - Forte ondulado

RELEVO REGIONAL - Plano a Montanhoso

EROSÃO - Em sulco.

DRENAGEM - Bem drenado.

VEGETAÇÃO PRIMÁRIA - Floresta Tropical

USO ATUAL - Vegetação nativa

CLIMA - Tropical de savana, Cwa da classificação de Koppen

DESCRITO E COLETADO POR - Rosana Quirino de Souza 


\section{DESCRIÇÃO DO PERFIL DE NITOSSOLO VERMELHO Eutrófico}

chernossólico

PERFIL N ${ }^{\circ}-03$

DATA: 04/10/2013

CLASSIFICAÇÃO - NITOSSOLO VERMELHO Eutrófico textura muito argilosa A chernozêmico.

LOCALIZAÇÃO, MUNICÍPIO, ESTADO E COORDENADAS - Tendo como ponto de partida a Fundação Zoobotânica do Distrito Federal, siga 14,5 Km na Rodovia DF105 até alcançar o ponto de encontro com a rodovia DF-250. Siga por mais $20 \mathrm{Km}$ à esquerda na DF-250 e, em seguida, siga à direita na vicinal, Brasília - DF, UTM 18496 S (fuso $23 \mathrm{~S}$ ) $8283155 \mathrm{~W}$ (fuso $23 \mathrm{~S}$ )

SITUAÇÃO, DECLIVE E COBERTURA VEGETAL SOBRE O PERFIL - Descrito e coletado em perfil de estrada, declividade 19\%, sob vegetação nativa de Floresta.

ALTITUDE - $758 \mathrm{~m}$

LITOLOGIA - Carbonato Filito.

FORMAÇÃO GEOLÓGICA - Grupo Canastra, Unidade Carbonato Filito.

CRONOLOGIA - Meso/Neoproterozóico

MATERIAL ORIGINÁRIO - Carbonato Filito.

PEDREGOSIDADE - Não pedregoso

ROCHOSIDADE - Não rochoso

RELEVO LOCAL - Ondulado

RELEVO REGIONAL - Plano a Montanhoso

EROSÃO - Em sulco.

DRENAGEM - Moderadamente drenado.

VEGETAÇÃO PRIMÁRIA - Floresta Tropical Subcaducifólia

USO ATUAL - Pastagem

CLIMA - Tropical de savana, Cwa da classificação de Koppen

DESCRITO E COLETADO POR - Bruna Gonçalves Vieira 


\section{DESCRIÇÃO DO PERFIL DE NITOSSOLO VERMELHO Eutrófico}

chernossólico

PERFIL N ${ }^{\circ}-04$

DATA: $11 / 10 / 2013$

CLASSIFICAÇÃO - NITOSSOLO VERMELHO Eutrófico textura muito argilosa A chernozêmico.

LOCALIZAÇÃO, MUNICÍPIO, ESTADO E COORDENADAS - Tendo como ponto de partida a Fundação Zoobotânica do Distrito Federal, siga 14,5 Km na Rodovia DF105 até alcançar o ponto de encontro com a rodovia DF-250. Siga por mais $20 \mathrm{Km}$ à esquerda na DF-250 e, em seguida, siga à direita em uma estrada vicinal, Brasília - DF, UTM 181448 S (fuso $23 \mathrm{~S}$ ) $8282685 \mathrm{~W}$ (fuso $23 \mathrm{~S}$ )

SITUAÇÃO, DECLIVE E COBERTURA VEGETAL SOBRE O PERFIL - Descrito e coletado em perfil de estrada, declividade 9\%, sob vegetação nativa de Floresta.

ALTITUDE - $761 \mathrm{~m}$

LITOLOGIA - Lentes Calcárias

FORMAÇÃO GEOLÓGICA - Grupo Canastra, Unidade Lentes Calcárias.

CRONOLOGIA - Meso/Neoproterozóico

MATERIAL ORIGINÁRIO - Rochas Calciossilicatadas associadas a Calcários.

PEDREGOSIDADE - Não pedregoso

ROCHOSIDADE - Não rochoso

RELEVO LOCAL - Ondulado

EROSÃO - Em sulco.

DRENAGEM - Moderadamente drenado.

VEGETAÇÃO PRIMÁRIA - Floresta Tropical Subcaducifólia

USO ATUAL - Vegetação nativa

CLIMA - Tropical de savana, Cwa da classificação de Koppen

DESCRITO E COLETADO POR - Bruna Gonçalves Vieira 


\section{DESCRIÇÃO DO PERFIL DE CHERNOSSOLO HÁPLICO Férrico típico}

PERFIL N ${ }^{\circ}-05$

DATA: 04/04/2014

CLASSIFICAÇÃO - CHERNOSSOLO HÁPLICO Férrico argila de alta atividade fase floresta tropical relevo ondulado.

LOCALIZAÇÃO, MUNICÍPIO, ESTADO E COORDENADAS - Às margens da Rodovia DF-205, 183864 S (fuso 23) 8275994 W (fuso 23).

SITUAÇÃO, DECLIVE E COBERTURA VEGETAL SOBRE O PERFIL - Descrito e coletado em perfil de estrada, declividade $11 \%$, sob vegetação nativa de Mata Seca Semidecídua.

ALTITUDE - $887 \mathrm{~m}$

LITOLOGIA - Clorita Carbonato Filito.

FORMAÇÃO GEOLÓGICA - Grupo Canastra, Unidade Clorita Carbonato Filito.

CRONOLOGIA - Meso/Neoproterozóico

MATERIAL ORIGINÁRIO - Clorita Carbonato Filito.

PEDREGOSIDADE - Pedregoso

ROCHOSIDADE - Não rochoso

RELEVO LOCAL - Ondulado

RELEVO REGIONAL - Plano a Montanhoso

EROSÃO - Em sulco.

DRENAGEM - Bem drenado.

VEGETAÇÃO PRIMÁRIA - Mata Seca Semidecídua

USO ATUAL - Vegetação nativa

CLIMA - Tropical de savana, Cwa da classificação de Koppen

DESCRITO E COLETADO POR - Rosana Quirino de Souza 


\section{DESCRIÇÃO DO PERFIL DE ARGISSOLO VERMELHO Eutroférrico típico}

PERFIL N ${ }^{\circ}-06$

DATA: 04/04/2014

CLASSIFICAÇÃO - ARGISSOLO VERMELHO Eutroférrico argila de atividade baixa A proeminente.

LOCALIZAÇÃO, MUNICÍPIO, ESTADO E COORDENADAS - Próximo a Rodovia DF-205, 183565 S (fuso 23) $8277162 \mathrm{~W}$ (fuso 23)

SITUAÇÃO, DECLIVE E COBERTURA VEGETAL SOBRE O PERFIL - Descrito e coletado em perfil de estrada, declividade 4\%, sob vegetação nativa de pastagem

ALTITUDE - $871 \mathrm{~m}$

LITOLOGIA - Psamo Pelito Carbonatada.

FORMAÇÃO GEOLÓGICA - Grupo Paranoá, Unidade Psamo Pelito Carbonatada.

CRONOLOGIA - Meso/Neoproterozóico

MATERIAL ORIGINÁRIO - Psamo Pelito Carbonatada.

PEDREGOSIDADE - Não pedregoso

ROCHOSIDADE - Não rochoso

RELEVO LOCAL - Suave Ondulado

RELEVO REGIONAL - Plano a Montanhoso

EROSÃO - Em sulco.

DRENAGEM - Moderadamente drenado.

VEGETAÇÃO PRIMÁRIA - Mata Seca Semidecídua

USO ATUAL - Pastagem

CLIMA - Tropical de savana, Cwa da classificação de Koppen

DESCRITO E COLETADO POR - Rosana Quirino de Souza 


\section{DESCRIÇÃO DO PERFIL DE ARGISSOLO VERMELHO-AMARELO}

\section{Distrófico típico}

PERFIL N ${ }^{\circ}-07$

DATA: 09/05/2014

CLASSIFICAÇÃO - ARGISSOLO VERMELHO-AMARELO Distrófico textura argilosa A proeminente

LOCALIZAÇÃO, MUNICÍPIO, ESTADO E COORDENADAS - Estrada do Catingueiro, próximo ao Córrego Barreirão e próximo a DF - 205, 184544 S (fuso 23) $8278838 \mathrm{~W}$ (fuso 23)

SITUAÇÃO, DECLIVE E COBERTURA VEGETAL SOBRE O PERFIL - Descrito e coletado em perfil de estrada, declividade $11 \%$, sob vegetação nativa de Mata Seca Semidecídua.

ALTITUDE - $837 \mathrm{~m}$

LITOLOGIA - Carbonato Filito.

FORMAÇÃO GEOLÓGICA - Grupo Canastra, Unidade Carbonato Filito.

CRONOLOGIA - Meso/Neoproterozóico

MATERIAL ORIGINÁRIO - Carbonato Filito.

PEDREGOSIDADE - Não pedregoso

ROCHOSIDADE - Não rochoso

RELEVO LOCAL - Ondulado

RELEVO REGIONAL - Plano a Montanhoso

EROSÃO - Em sulco.

DRENAGEM - Moderadamente drenado.

VEGETAÇÃO PRIMÁRIA - Mata Seca Semidecídua

USO ATUAL - Vegetação nativa

CLIMA - Tropical de savana, Cwa da classificação de Koppen

DESCRITO E COLETADO POR - Rosana Quirino de Souza 


\section{DESCRIÇÃO DO PERFIL DE NITOSSOLO VERMELHO Distroférrico típico}

PERFIL N ${ }^{\circ}-08$

DATA: 09/05/2014

CLASSIFICAÇÃO - NISSOLO VERMELHO Alumínico textura argilosa A moderado LOCALIZAÇÃO, MUNICÍPIO, ESTADO E COORDENADAS - Próximo a Rodovia DF-205, 183409 S (fuso 23) $8277372 \mathrm{~W}$ (fuso 23)

SITUAÇÃO, DECLIVE E COBERTURA VEGETAL SOBRE O PERFIL - Descrito e coletado em perfil de estrada, declividade $17 \%$, sob vegetação nativa de pastagem

ALTITUDE - $896 \mathrm{~m}$

LITOLOGIA - Psamo Pelito Carbonatada.

FORMAÇÃO GEOLÓGICA - Grupo Paranoá, Unidade Psamo Pelito Carbonatada.

CRONOLOGIA - Meso/Neoproterozóico

MATERIAL ORIGINÁRIO - Psamo Pelito Carbonatada.

PEDREGOSIDADE - Não pedregoso

ROCHOSIDADE - Não rochoso

RELEVO LOCAL - Forte ondulado

RELEVO REGIONAL - Plano a Montanhoso

EROSÃO - Em sulco.

DRENAGEM - Bem drenado.

VEGETAÇÃO PRIMÁRIA - Mata Seca Semidecídua

USO ATUAL - Pastagem

CLIMA - Tropical de savana, Cwa da classificação de Koppen

DESCRITO E COLETADO POR - Rosana Quirino de Souza 


\section{DESCRIÇÃO DO PERFIL DE NITOSSOLO HÁPLICO Distrófico típico}

PERFIL N ${ }^{\circ}-09$

DATA: 03/07/2014

CLASSIFICAÇÃO - NITOSSOLO HÁPLICO Distrófico textura argilosa A moderado LOCALIZAÇÃO, MUNICÍPIO, ESTADO E COORDENADAS - Próximo a Rodovia DF-330 sentido Pedreira, 183107 S (fuso 23) 8281964 W (fuso 23)

SITUAÇÃO, DECLIVE E COBERTURA VEGETAL SOBRE O PERFIL - Descrito e coletado em perfil de estrada, declividade $35 \%$, sob vegetação nativa de pastagem.

ALTITUDE - $792 \mathrm{~m}$

LITOLOGIA - Psamo Pelito Carbonatada.

FORMAÇÃO GEOLÓGICA - Grupo Paranoá, Unidade Psamo Pelito Carbonatada.

CRONOLOGIA - Meso/Neoproterozóico

MATERIAL ORIGINÁRIO - Psamo Pelito Carbonatada.

PEDREGOSIDADE - Pedregoso

ROCHOSIDADE - Não rochoso

RELEVO LOCAL - Forte ondulado

RELEVO REGIONAL - Plano a Montanhoso

EROSÃO - Em sulco.

DRENAGEM - Bem drenado.

VEGETAÇÃO PRIMÁRIA - Mata Seca Semidecídua

USO ATUAL - Pastagem

CLIMA - Tropical de savana, Cwa da classificação de Koppen

DESCRITO E COLETADO POR - Rosana Quirino de Souza 


\section{DESCRIÇÃO DO PERFIL DE ARGISSOLO VERMELHO Eutroférrico típico}

PERFIL N ${ }^{\circ}-10$

DATA: 03/07/2014

CLASSIFICAÇÃO - ARGISSOLO VERMELHO-AMARELO Eutrófico argila de atividade baixa A proeminente

LOCALIZAÇÃO, MUNICÍPIO, ESTADO E COORDENADAS - Estrada do Catingueiro, próximo ao Ribeirão Água Doce e próximo a DF - 205, UTM 184872 S (fuso 23) $8277419 \mathrm{~W}$ (fuso 23).

SITUAÇÃO, DECLIVE E COBERTURA VEGETAL SOBRE O PERFIL - Descrito e coletado em perfil de estrada, declividade $3 \%$, sob vegetação nativa de pastagem

ALTITUDE - $849 \mathrm{~m}$

LITOLOGIA - Carbonato Filito.

FORMAÇÃO GEOLÓGICA - Grupo Canastra, Unidade Carbonato Filito.

CRONOLOGIA - Meso/Neoproterozóico

MATERIAL ORIGINÁRIO - Carbonato Filito.

PEDREGOSIDADE - Não pedregoso

ROCHOSIDADE - Não rochoso

RELEVO LOCAL - Plano

RELEVO REGIONAL - Plano a Montanhoso

EROSÃO - Em sulco.

DRENAGEM - Moderadamente drenado.

VEGETAÇÃO PRIMÁRIA - Mata Seca Semidecídua

USO ATUAL - Pastagem

CLIMA - Tropical de savana, Cwa da classificação de Koppen

DESCRITO E COLETADO POR - Rosana Quirino de Souza 